Nevada

Environmental

Restoration

Project

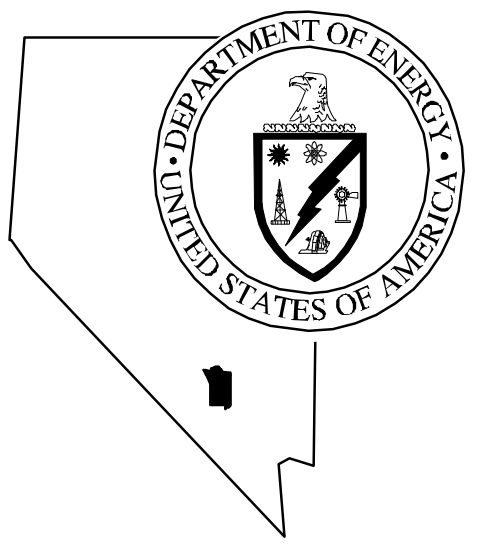

Corrective Action Decision Docum ent for Corrective Action Unit 3 42:

Area 23 M ercury Fire Training $P$ it,

$\mathrm{N}$ evada Test Site, $\mathrm{N}$ evada

Controlled Copy N $0 .:$

Revision N 0.: 1

J une 1999

Approved for public release; further dissemination unlimited.

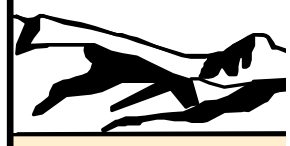

Environm ental Restoration

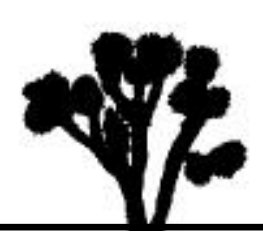

Division 
Available to the public from -

\author{
U.S. Department of Commerce \\ National Technical Information Service \\ 5285 Port Royal Road \\ Springfield, VA 22161 \\ (703) 487-4650
}

Available electronically at http://www.doe.gov/bridge. Available to

U.S. Department of Energy and its contractors in paper from -

U.S. Department of Energy

Office of Scientific and Technical Information

P.O. Box 62

Oak Ridge, TN 37831-0062

(423) 576-8401

Reference herein to any specific commercial product, process, or service by trade name, trademark, manufacturer, or otherwise, does not necessarily constitute or imply its endorsement, recommendation, or favoring by the United States Government or any agency thereof or its contractors or subcontractors 


\title{
CORRECTIVE ACTION DECISION DOCUMENT FOR CORRECTIVE ACTION UNIT 342: AREA 23 MERCURY FIRE TRAINING PIT, NEVADA TEST SITE, NEVADA
}

\author{
DOE Nevada Operations Office \\ Las Vegas, Nevada
}

Controlled Copy No.:

Revision No.: 1

June 1999

Approved for public release; further dissemination unlimited. 


\section{CORRECTIVE ACTION DECISION DOCUMENT FOR CORRECTIVE ACTION UNIT 342: AREA 23 MERCURY FIRE TRAINING PIT, NEVADA TEST SITE, NEVADA}

Approved by:

Date:

Janet Appenzeller-Wing, Project Manager

Industrial Sites Project 


\section{Table of Contents}

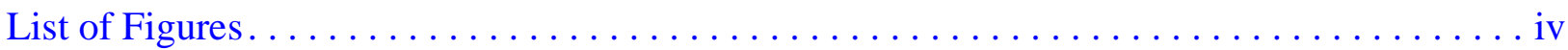

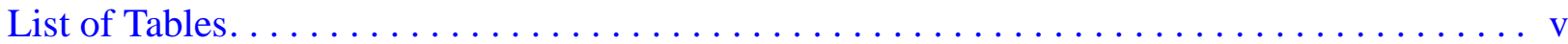

List of Acronyms and Abbreviations $\ldots \ldots \ldots \ldots \ldots \ldots \ldots \ldots \ldots \ldots \ldots \ldots \ldots \ldots \ldots \ldots$

Executive Summary . . . . . . . . . . . . . . . . . . . . .

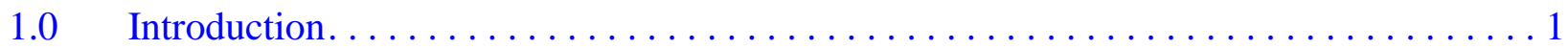

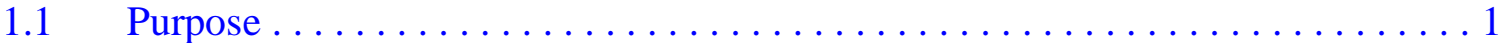

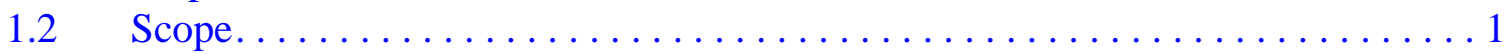

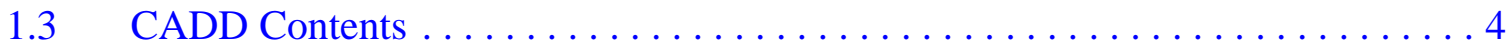

$2.0 \quad$ Corrective Action Investigation Summary $\ldots \ldots \ldots \ldots \ldots \ldots \ldots \ldots \ldots \ldots \ldots$

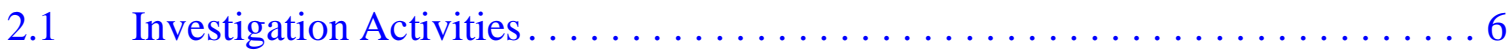

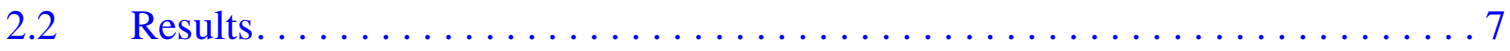

$2.3 \quad$ Need for Corrective Action. . . . . . . . . . . . . . . . . . . 8

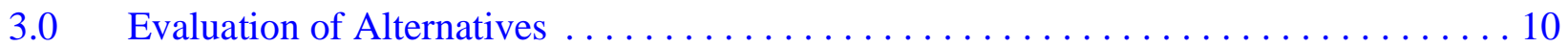

3.1 Corrective Action Objectives . . . . . . . . . . . . . . . . 10

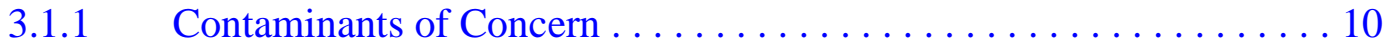

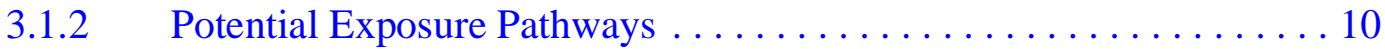

$3.2 \quad$ Screening Criteria . . . . . . . . . . . . . . . . . . . . . . 11

3.2.1 Corrective Action Standards . . . . . . . . . . . . . . . . . 11

3.2.2 Remedy Selection Decision Factors . . . . . . . . . . . . . . 13

3.3 Development of Corrective Action Alternatives . . . . . . . . . . . . . . 14

3.3.1 Alternative 1 - No Further Action. ................ 16

3.3.2 Alternative 2 - Closure in Place with Partial Excavation, Disposal, and Administrative Controls . . . . . . . . . . . 17

3.3.3 Alternative 3 - Partial Excavation, Disposal, In Situ Bioremediation and Administrative Controls . . . . . . . . . 20

3.3.4 Alternative 4 - Partial Excavation, Disposal, Monitoring, and Administrative Controls . . . . . . . . . . . . . . . . 21

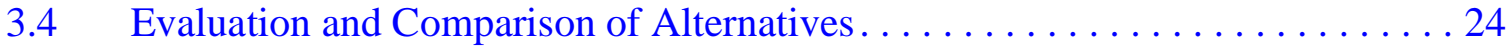

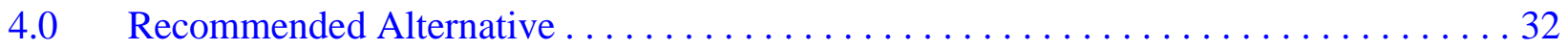

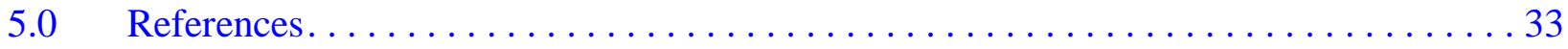

Appendix A - Corrective Action Investigation Report for Corrective Action Unit 342: Area 23 Mercury Fire Training Pit, Nevada Test Site

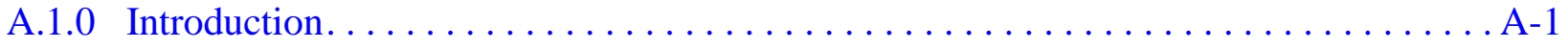

A.1.1 Project Objectives. . . . . . . . . . . . . . . . . . .

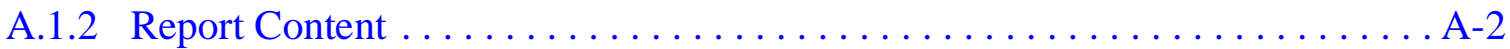




\section{Table of Contents (Continued)}

A.2.0 Field Investigation and Sampling Activities. . . . . . . . . . . . . . . A-3

A.2.1 Site Description and Conditions . . . . . . . . . . . . . . . A-3

A.2.2 Surface and Near-Surface Investigation . . . . . . . . . . . . A-5

A.2.2.1 Direct-Push Operation. . . . . . . . . . . . . . . . . A-5

A.2.2.2 Sample Collection......................... A-5

A.2.3 Subsurface Investigation. . . . . . . . . . . . . . . . A

A.2.3.1 Drilling Operations . . . . . . . . . . . . . . . A-12

A.2.3.2 Field Screening . . . . . . . . . . . . . . . . . . . A-12

A.2.3.3 Sample Collection.......................... A-13

A.2.4 Waste Management. . . . . . . . . . . . . . . . . . . . . A-16

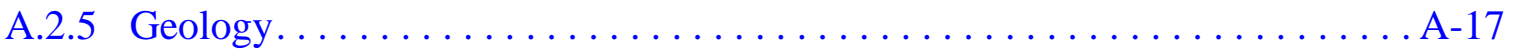

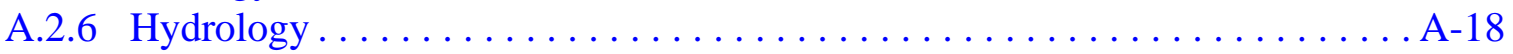

A.3.0 Investigation Results. . . . . . . . . . . . . . . . . . . . . . . . A-19

A.3.1 Total Petroleum Hydrocarbon Analytical Results . . . . . . . . . . . . . . . A-21

A.3.1.1 Aboveground Storage Tanks Area . . . . . . . . . . . . . . A A-22

A.3.1.2 Burn Area Near Bus . . . . . . . . . . . . . . . . . . A-24

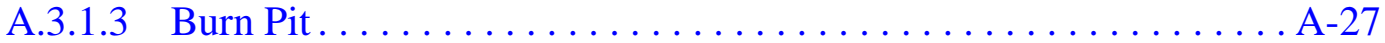

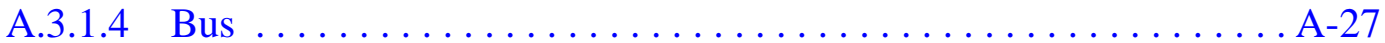

A.3.1.5 Cable Racks. . . . . . . . . . . . . . . . . . . . A-27

A.3.1.6 Pallets and Wood Debris....................... A-27

A.3.1.7 Sheds................................. A-29

A.3.1.8 Stained Soil Areas. . . . . . . . . . . . . . . . . . . . A A-29

A.3.1.9 Telephone Poles . . . . . . . . . . . . . . . . . . . A-30

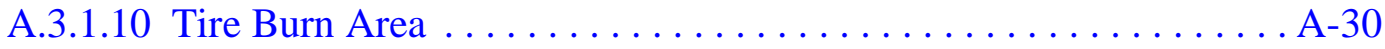

A.3.1.11 Borehole B-4........................ A-30

A.3.2 Total Volatile Organic Compound Analytical Results . . . . . . . . . . . . . . . A-30

A.3.3 TCLP Volatile Organic Compounds Analytical Results . . . . . . . . . . . . A A-34

A.3.4 Total Semivolatile Organic Compound Analytical Results . . . . . . . . . . . A A-35

A.3.5 Total RCRA Metals and Zinc Analytical Results. . . . . . . . . . . . . . . . A-35

A.3.6 TCLP Metals Analytical Results . . . . . . . . . . . . . . . . . . A-35

A.3.7 Dioxins and Furans Analytical Results. . . . . . . . . . . . . . . A-41

A.3.8 Polychlorinated Biphenyls Analytical Results . . . . . . . . . . . . . . A-41

A.3.9 Gamma Spectroscopy Results . . . . . . . . . . . . . . . . A-42

A.3.10 Bioassessment and Geotechnical Results . . . . . . . . . . . . . . . A-44

A.3.10.1 Bioassessment Results . . . . . . . . . . . . . . A-44

A.3.10.2 Geotechnical Results. . . . . . . . . . . . . . . A-45

A.4.0 Quality Assurance. .............................. A-46

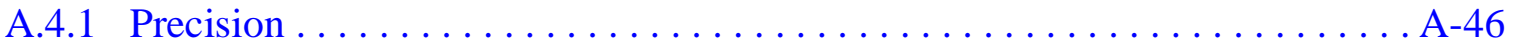




\section{Table of Contents (Continued)}

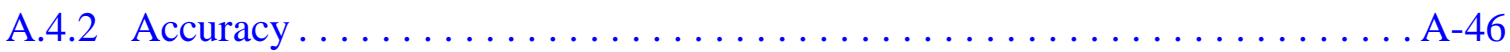

A.4.3 Representativeness . . . . . . . . . . . . . . . . . . . . . . . A-47

A.4.4 Completeness . . . . . . . . . . . . . . . . . . . . . . . . A-47

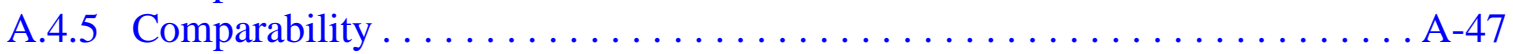

A.4.6 Tier I and Tier II Data Evaluations . . . . . . . . . . . . . . . A-48

A.4.6.1 Tier I Evaluation . . . . . . . . . . . . . . . . . . A-48

A.4.6.2 Tier II Evaluation . . . . . . . . . . . . . . . . . . . A-49

A.4.6.3 Tier III Evaluation. . . . . . . . . . . . . . . . . . . A

A.4.7 Quality Control Samples. . . . . . . . . . . . . . . . . . A-51

A.4.7.1 Field Quality Control Samples . . . . . . . . . . . . . A A-52

A.4.7.2 Laboratory Quality Control Samples . . . . . . . . . . . . . . . A-53

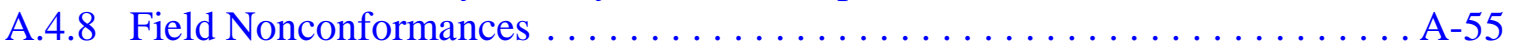

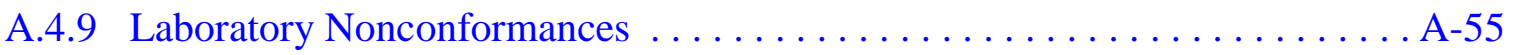

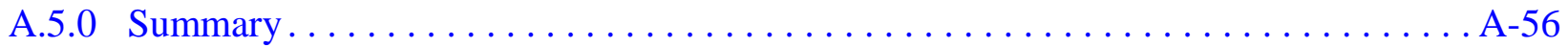

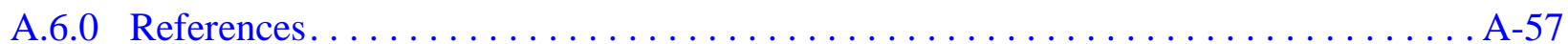

Appendix B - Soil Boring Logs

Appendix C - Geotechnical Sample Results

Appendix D - Cost Estimates

Appendix E - Bioassessment Report, Nevada Test Site, CAU 342 (Area 23 Mercury Fire Training Pit)

Appendix F - Nevada Environmental Restoration Project Document Review Sheet 


\section{List of Figures}

Number

1-1 Nevada Test Site. . . . . . . . . . . . . . . . . . . . . . . 2

1-2 Area 23 Mercury Fire Training Pit, Nevada Test Site ................ 3

3-1 Potential Areas of Excavation, Area 23 Mercury Fire Training Pit, Nevada Test Site. ................................ 18

3-2 Potential Auger Locations, Area 23 Mercury Fire Training Pit, Nevada Test Site. . . . . . . . . . . . . . . . . . . . . . . . . . . . . . . . . . . 19

3-3 Proposed Soil Gas Sampling Well Location ..................... 23

A.2-1 Aerial View of the Mercury Fire Training Pit $\ldots \ldots \ldots \ldots \ldots \ldots \ldots$ A-4

A.2-2 Direct-Push and Manual Sample Collection Locations for Mercury Fire Training Pit . . . . . . . . . . . . . .

A.2-3 Borehole Locations for Mercury Fire Training Pit. . . . . . . . . . . A-11

A.3-1 Lateral Extent of the TPH Plumes at the Mercury Fire Training Pit . . . . . . A-23

A.3-2 Cross Section of AST Subsurface Plume (West/East) . . . . . . . . . . . A-25

A.3-3 Cross Section of AST Subsurface Plume (North/South) . . . . . . . . . . . . A-26

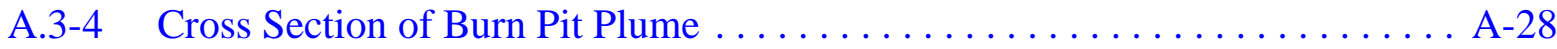




\section{List of Tables}

Number

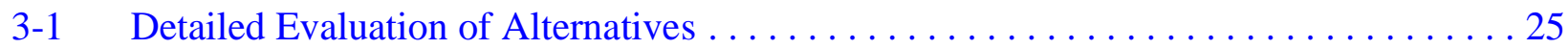

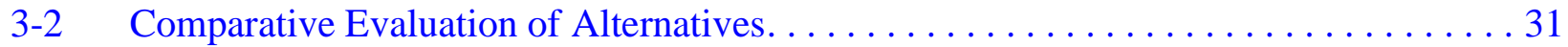

A.2-1 Direct-Push and Surface Sample Locations and Analyses for Mercury Fire Training Pit . . . . . . . . . . . . . . . . $\ldots \ldots \ldots$

A.2-2 Samples Collected During Subsurface Investigation at the Mercury Fire Training Pit.

A.3-1 Laboratory Analytical Methods Used for the Mercury Fire Training Pit Investigation Soil Samples

A.3-2 Soil Sample Results for Total Petroleum Hydrocarbons Detected Above Minimum Reporting Limits, Mercury Fire Training Pit, Nevada Test Site . .

A.3-3 Soil Sample Results for Total Volatile Organic Compounds Detected Above the Minimum Reporting Limit, Mercury Fire Training Pit, Nevada Test Site.

A.3-4 Soil Sample Results for Total Semivolatile Organic Compounds Detected Above Minimum Reporting Limits, Mercury Fire Training Pit, Nevada Test Site . . . . . . . A-36

A.3-5 Soil Sample Results for Total RCRA Metals and Zinc Detected Above Minimum Reporting Limits, Mercury Fire Training Pit, Nevada Test Site . . . . . . . . . . A-37

A.3-6 Soil Sample Results for TCLP Metals Detected Above Minimum Reporting Limits, Mercury Fire Training Pit, Nevada Test Site . . . . . . . . . . . . . . . . A-42

A.3-7 Soil Sample Results for Detected Radioactive Isotopes, Mercury Fire Training Pit, Nevada Test Site 


\section{List of Acronyms and Abbreviations}

AST Aboveground storage tank(s)

bgs Below ground surface

CADD Corrective Action Decision Document

CAIP Corrective Action Investigation Plan

CAS Corrective Action Site(s)

CAU Corrective Action Unit(s)

CFR Code of Federal Regulations

CLP Contract Laboratory Program

$\mathrm{cm} / \mathrm{sec} \quad$ Centimeter(s) per second

COC Contaminant(s) of concern

COPC Contaminant(s) of potential concern

DOE/NV U.S. Department of Energy, Nevada Operations Office

DQO Data Quality Objective(s)

EPA U.S. Environmental Protection Agency

FFACO Federal Facility Agreement and Consent Order

$\mathrm{ft} \quad$ Foot (feet)

$\mathrm{ft}^{2} \quad$ Square foot (feet)

FTP Mercury Fire Training Pit

ICP Inductively coupled plasma

in. $\quad \operatorname{Inch}(\mathrm{es})$

LCS Laboratory control sample(s)

$\mathrm{mg} / \mathrm{kg} \quad$ Milligram(s) per kilogram

$\mathrm{mg} / \mathrm{L} \quad$ Milligram(s) per liter

$\mu \mathrm{g} / \mathrm{kg} \quad$ Microgram(s) per kilogram

mi Mile(s)

MEK Methylethyl ketone (2-butanone)

MIBK Methyl isobutyl ketone 


\section{List of Acronyms and Abbreviations (Continued)}

MS/MSD Matrix spike/matrix spike duplicate

NAC Nevada Administrative Code

NDEP Nevada Division of Environmental Protection

NIST National Institute of Standards and Technology

NRS Nevada Revised Statutes

NTS Nevada Test Site

PAL Preliminary action level(s)

PCB Polychlorinated biphenyl(s)

$\mathrm{pCi} / \mathrm{g} \quad$ Picocurie(s) per gram

PE Polyethylene

PID Photoionization detector

PPE Personal protective equipment

PRG Preliminary remediation goal(s)

QA Quality assurance

QA/QC Quality assurance and quality control

QAPP Quality Assurance Project Plan

QC Quality control

RCRA Resource Conservation and Recovery Act

RPD Relative percent difference

SDG Sample delivery group

SVOC Semivolatile organic compound(s)

TCLP Toxicity characteristic leaching procedure

TPH Total petroleum hydrocarbon(s)

VOC Volatile organic compound(s)

$\% \mathrm{R} \quad$ Percent recovery

$\mu \mathrm{g} / \mathrm{kg} \quad$ Microgram(s) per kilogram 


\section{Executive Summary}

This Corrective Action Decision Document has been prepared for the Nevada Test Site's Area 23 Mercury Fire Training Pit (Corrective Action Unit 342) in accordance with the Federal Facility Agreement and Consent Order (FFACO, 1996). Corrective Action Unit 342 is comprised of Corrective Action Site 23-56-01. The purpose of this Corrective Action Decision Document is to identify and provide a rationale for the selection of a recommended corrective action alternative for Corrective Action Unit 342.

The scope of this document consists of the following:

- Develop corrective action objectives.

- Identify corrective action alternative screening criteria.

- Develop corrective action alternatives.

- Perform detailed and comparative evaluations of corrective action alternatives in relation to corrective action objectives and screening criteria.

- Recommend and justify a preferred corrective action alternative for the Corrective Action Unit.

In May and June 1998, a corrective action investigation was performed as set forth in the Corrective Action Investigation Plan for Corrective Action Unit 342: Area 23 Mercury Fire Training Pit, Nevada Test Site, Nevada (DOE/NV, 1998). Unknown hydrocarbons were detected in the total petroleum hydrocarbon diesel analyses at concentrations ranging from nondetect to 10,000 milligrams per kilogram. These unknown hydrocarbons could be attributed to aromatic, halogenated and nonhalogenated volatile and semivolatile compounds and/or other petroleum hydrocarbons (i.e., nongasoline, nondiesel, and nonwaste oil) present in the samples. Total petroleum hydrocarbons were identified at concentrations above the 100 milligrams per kilogram action level specified in the Nevada Administrative Code (NAC, 1996a). These detections were primarily related to plumes associated with the aboveground storage tank storage area and the burn pit. The surface soil immediately downgradient of the burn pit and several stained areas also had concentrations exceeding the 100 milligrams per kilogram action level. The aboveground storage tank storage area subsurface plume is limited vertically to 50 feet. The lateral extent does 
not exceed 130 by 80 feet. The burn pit plume is limited vertically to 30 feet and laterally to not more than a few feet beyond the dimensions of the surface berm ( 65 by 27 feet). The highest detected concentration of total petroleum hydrocarbon was 18,000 milligrams per kilogram as diesel in boring B-14 in the aboveground storage tank storage area at the 24 to 25 feet below ground surface sampling interval. Xylene was detected in one sample at a concentration exceeding the preliminary action level. This xylene detection, as well as those less than the preliminary action levels, were associated with the hydrocarbon detections and should therefore be limited to the extent of the hydrocarbon plume. The lateral extent of the hydrocarbon contamination is shown on Figure A.3-1. Details of the investigation can be found in Appendix A of this document.

Based on the potential exposure pathways, the following corrective action objectives have been identified for Corrective Action Unit 342:

- Prevent or mitigate exposure to surface, near-surface, and subsurface soil containing contaminants of concern at concentrations exceeding preliminary action levels (DOE/NV, 1998).

- Prevent adverse impacts to groundwater quality.

Upon review of existing data, future use, and current operations at the Nevada Test Site, the following alternatives were developed for consideration at Corrective Action Unit 342:

- Alternative 1 - No Further Action

- Alternative 2 - Closure in Place with Partial Excavation, Disposal, and Administrative Controls

- Alternative 3 - Partial Excavation, Disposal, and In Situ Bioremediation

- Alternative 4 - Partial Excavation, Disposal, and Monitoring

The corrective action alternatives were evaluated based on four general corrective action standards and five remedy selection decision factors. Based on the results of this evaluation, the preferred alternative for Corrective Action Unit 342 is Alternative 4, Partial Excavation, Disposal, and Monitoring. 
The preferred corrective action alternative was evaluated on technical merit, focusing on performance, reliability, feasibility, and safety. The alternative was judged to meet all requirements for the technical components evaluated, all applicable state and federal regulations for closure of the site, and will reduce potential future exposure pathways to the contaminated soil at the Mercury Fire Training Pit.

This alternative will present minor risks to site workers during corrective action implementation. Therefore, appropriate health and safety procedures will be developed and implemented. 


\subsection{Introduction}

This Corrective Action Decision Document (CADD) has been prepared for Corrective Action Unit (CAU) 342, Area 23 Mercury Fire Training Pit (FTP) in accordance with the Federal Facility Agreement and Consent Order (FFACO) that was agreed to by the U.S. Department of Energy, Nevada Operations Office (DOE/NV); the Nevada Division of Environmental Protection (NDEP); and the U.S. Department of Defense (FFACO, 1996). The CADD provides or references the specific information necessary to recommend a preferred corrective action for the single Corrective Action Site (CAS), 23-56-01, within CAU 342.

Corrective Action Unit 342 is located at the Nevada Test Site (NTS) in Area 23. The NTS is approximately 65 miles (mi) northwest of Las Vegas, Nevada (Figure 1-1). The FTP is an area approximately 350 by 450 feet (ft) located west of Mercury, Nevada, which was used between approximately 1965 and 1990 to train fire-fighting personnel (Figure 1-2) (REECo, 1991; Jacobson, 1991).

\subsection{Purpose}

This CADD identifies potential corrective action alternatives and provides a rationale for the selection of a recommended alternative for the CAU. The need for these alternatives is based on process knowledge and the results of the investigative activities conducted in accordance with the Corrective Action Investigation Plan for Corrective Action Unit 342: Area 23 Mercury Fire Training Pit, Nevada Test Site, Nevada (DOE/NV, 1998). The CAU is the same as described in the Corrective Action Investigation Plan (CAIP) except for surface features that were removed.

\subsection{Scope}

The scope of this CADD consists of the following:

- Develop corrective action objectives.

- Identify corrective action alternative screening criteria.

- Develop corrective action alternatives. 


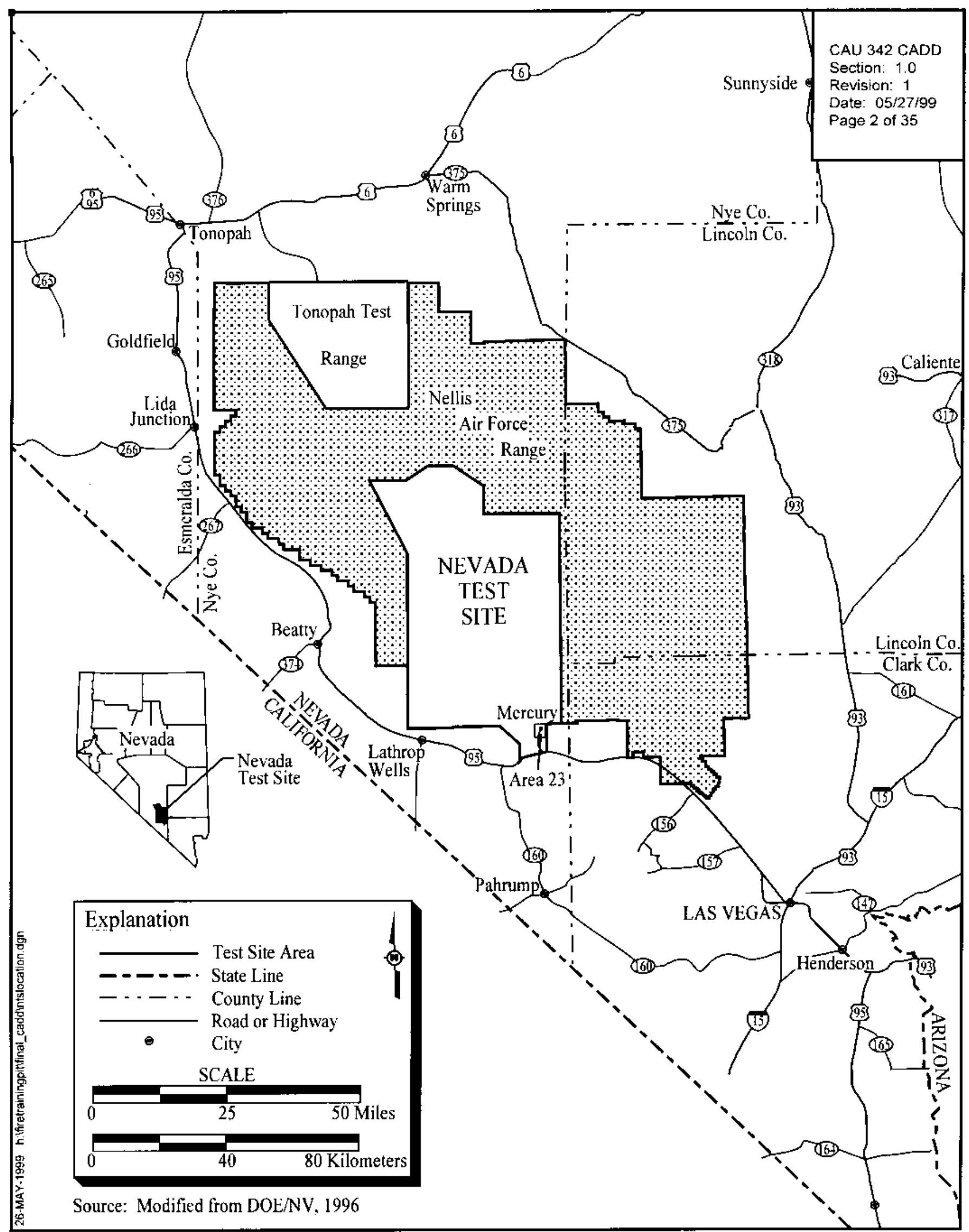

Figure 1-1

Nevada Test Site 


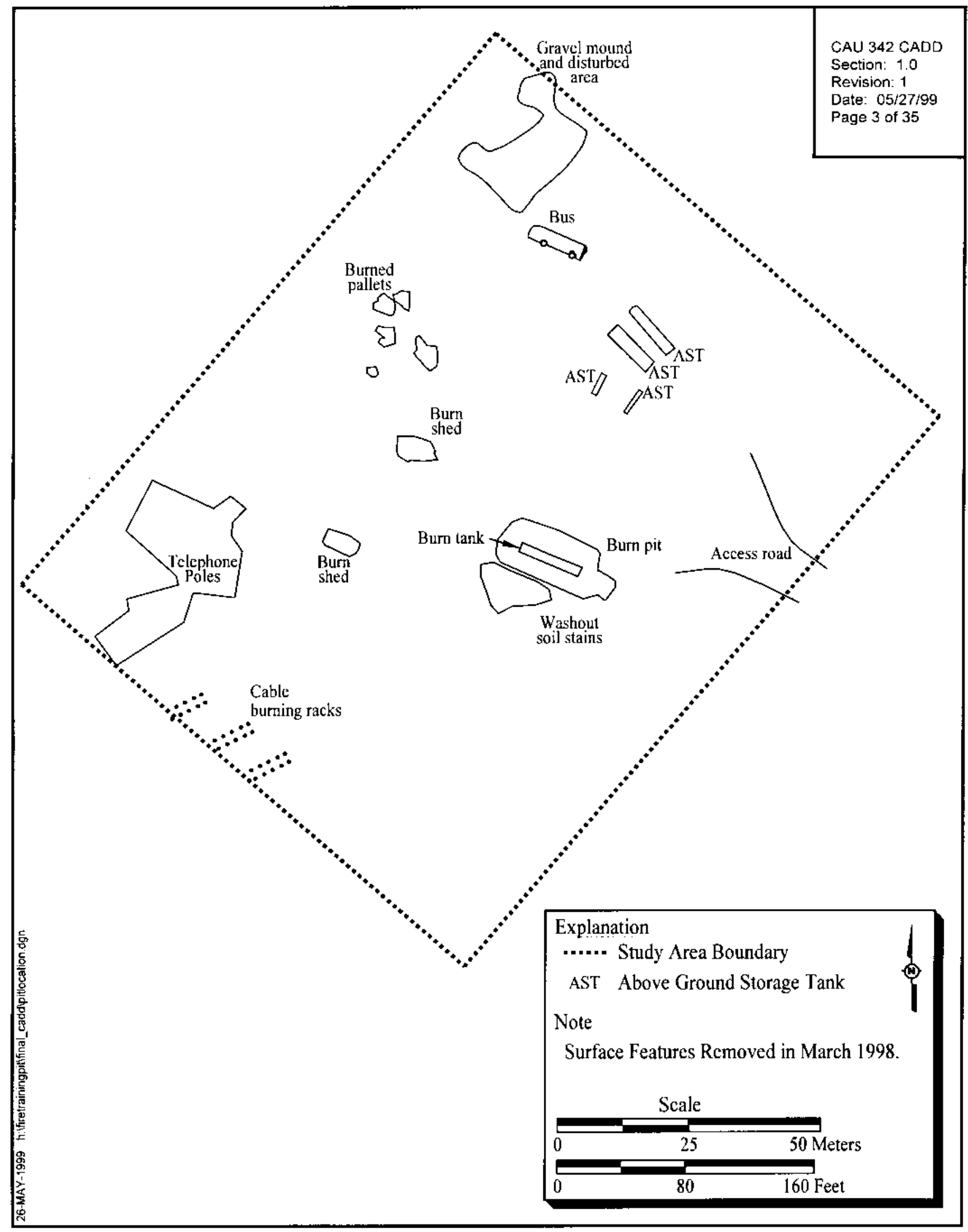

Figure 1-2

Area 23 Mercury Fire Training Pit, Nevada Test Site 
- Perform detailed and comparative evaluations of corrective action alternatives in relation to corrective action objectives and screening criteria.

- Recommend and justify a preferred corrective action alternative for the CAU.

\section{$1.3 \quad C A D D$ Contents}

This CADD is divided into the following sections:

Section 1.0 - Introduction: summarizes the purpose, scope, and contents of this CADD.

Section 2.0 - Corrective Action Investigation Summary: summarizes the investigation field activities, the results of the investigation, and the need for corrective action.

Section 3.0 - Evaluation of Alternatives: documents steps taken to determine a preferred corrective action alternative.

Section 4.0 - Recommended Alternative: presents the preferred corrective action alternative and the rationale for its selection based on the corrective action objectives and alternative screening criteria.

Section 5.0 - References: provides a list of all referenced documents.

Appendix A: Corrective Action Investigation Report for Corrective Action Unit 342: Area 23

Mercury Fire Training Pit, Nevada Test Site

Appendix B: Soil Boring Logs

Appendix C: Geotechnical Sample Results

Appendix D: Cost Estimates

Appendix E: Bioassessment Report, Nevada Test Site, CAU 342 (Area 23 Mercury Fire Training Pit)

Appendix F: Nevada Environmental Restoration Project Documentation Review Sheets 
All work was performed in accordance with the following documents:

- Corrective Action Investigation Plan for Corrective Action Unit 342: Area 23 Mercury Fire Training Pit, Nevada Test Site, Nevada (DOE/NV, 1998)

- Industrial Sites Quality Assurance Project Plan (DOE/NV, 1996b)

- FFACO (FFACO, 1996)

- Project Management Plan (DOE/NV, 1994) 


\subsection{Corrective Action Investigation Summary}

The following sections describe and summarize the results of the investigation activities conducted at CAU 342. Detailed investigation results and minor deviations from the CAIP are presented in Appendix A.

\section{$2.1 \quad$ Investigation Activities}

In May and June 1998, corrective action investigation activities were performed as set forth in the CAIP (DOE/NV, 1998). The purpose of the investigation was to:

- Identify the presence and nature of contaminants of potential concern (COPCs) at the FTP.

- Determine the vertical and lateral extent of COPCs at the FTP.

- Provide sufficient information and data to develop and evaluate appropriate corrective action for the CAU.

The investigation activities are summarized below:

- Conducted a biological resources survey prior to sample collection. No endangered species were identified on the site.

- Collected surface/near-surface soil samples for laboratory analysis from 31 random and biased locations using a direct-push sampling method and from three biased locations using hand tools (Figure A.2-2 shows these locations).

- Drilled 17 soil borings in and around each of the point source areas using a rotary sonic drilling method. The borings ranged in depth from 15 to $70 \mathrm{ft}$.

- Collected subsurface soil samples from each of the borings for field screening and laboratory analysis (Figure A.2-3 shows boring locations).

- Field-screened soil samples for volatile organic compounds (VOCs), total petroleum hydrocarbons (TPH), and alpha/beta emitters.

- Analyzed environmental samples (soil and quality control [QC] samples) from the investigation for one or all of the following: total and leachable VOCs; total semivolatile organic compounds (SVOCs); total and leachable Resource Conservation and Recovery Act (RCRA) metals and zinc; TPH; dioxans/furans; polychlorinated biphenyls (PCBs); and 
radionuclides using gamma spectroscopy. The results of these analyses were compared to preliminary action levels (PALs) as established in Section 3.3 of the CAIP (DOE/NV, 1998).

- Performed tests on bioassessment samples to ascertain $\mathrm{pH}$ levels, moisture content, background nutrient concentrations, microbial enumerations, and microbial stimulation response.

- Analyzed geotechnical samples from investigation borings for initial moisture content, dry bulk density, calculated porosity, saturated/unsaturated hydraulic conductivity, particle size distribution, and water-release curve.

\subsection{Results}

The corrective action investigation results indicated the following:

- Total petroleum hydrocarbons were identified at concentrations above the 100 milligrams per kilogram (mg/kg) action level specified in the Nevada Administrative Code (NAC) (NAC, 1996a). Unknown hydrocarbons were detected in the TPH diesel analyses at concentrations ranging from nondetect to $10,000 \mathrm{mg} / \mathrm{kg}$. These unknown hydrocarbons could be attributed to aromatic, halogenated and nonhalogenated volatile and semivolatile compounds and/or other petroleum hydrocarbons (i.e., nongasoline, nondiesel, and nonwaste oil) present in the samples. These detections were primarily related to plumes associated with the aboveground storage tank (AST) storage area and the burn pit. The surface soil immediately downgradient of the burn pit and several stained areas also had concentrations exceeding the $100 \mathrm{mg} / \mathrm{kg}$ action level. The AST area subsurface plume lobes appear to have had three different point sources. The northernmost and largest of the three lobes is limited vertically to $50 \mathrm{ft}$. The smaller two lobes are limited vertically to $30 \mathrm{ft}$ and $20 \mathrm{ft}$. Their combined lateral extent does not exceed 130 by $80 \mathrm{ft}$. The burn pit plume is limited vertically to $30 \mathrm{ft}$ and laterally to not more than a few feet beyond the dimensions of the surface berm (65 by $27 \mathrm{ft}$ ) (Figures A.3-1 through A.3-4 show plume locations). The highest detected hydrocarbon concentration was $18,000 \mathrm{mg} / \mathrm{kg}$ as diesel in boring B14 in the AST storage area at the 24 to $25 \mathrm{ft}$ sampling interval.

- For VOCs, only xylene was detected above its PAL. All other VOCs were below the PALs. A single detection of xylene was identified in boring B14 above the PAL. This detection corresponds with the highest TPH detection. All other xylene detections were below the PAL. A single sample was analyzed for leachable VOCs to support waste management. No constituents were identified above RCRA regulatory levels in this sample.

- No toxicity characteristic leaching procedure (TCLP) VOCs were detected above minimum reporting limits. 
- Total SVOCs were either not present above the minimum reporting limits, or if present, were below PALs. Detected SVOCs were identified within the TPH contaminated areas and are probably associated with the TPH constituents and degradation products.

- Only arsenic was detected in the total RCRA metals and zinc analyses above PALs. The arsenic concentrations ranged from $2.5 \mathrm{mg} / \mathrm{kg}$ to $10.8 \mathrm{mg} / \mathrm{kg}$. These concentrations are not unusual for the state of Nevada (Shacklette and Boerngen, 1984). No other total metals were detected above PALs. Analysis for leachable metals was conducted on two samples from the burn pit (sample selection criteria is discussed in Section A.3.6). Cadmium was detected above the regulatory limit of 1 milligrams per liter $(\mathrm{mg} / \mathrm{L})(\mathrm{CFR}, 1998)$ in both samples. Subsequently, additional samples were analyzed for leachable RCRA metals. No cadmium or other RCRA metals were detected in these samples. Matrix interference from high diesel concentrations may have masked the cadmium contamination in the totals analysis for the samples or a laboratory anomaly may have occurred in the analysis of these samples.

- No dioxins or furans were detected above minimum reporting limits.

- No PCBs were detected above minimum reporting limits.

- Radionuclides in the FTP soil samples were not distinguishable from soil samples taken from background locations and no man-made radionuclides were identified.

- Bioassessment samples indicated that viable microbial populations exist at the FTP and that soil conditions are suitable for bioremediation (natural or enhanced).

- Geotechnical results indicate the soils at the FTP are gravelly sand and sandy gravels with significant silt and clay. Isolated caliche layers are also present. Permeability tended to decrease with increasing depth.

Details of the methods used and results found during the investigation are presented in Appendix A.

\subsection{Need for Corrective Action}

Analytes detected during the corrective action investigation were evaluated against action levels to determine contaminants of concern (COCs) for CAU 342. Total petroleum hydrocarbons were detected above the $100 \mathrm{mg} / \mathrm{kg}$ action level (NAC 445A) (NAC, 1996b) in samples taken from soil below and around the AST storage area, the burn pit, and several isolated stained areas. Xylene was detected in one sample at 480,000 micrograms per kilogram $(\mu \mathrm{g} / \mathrm{kg})$ which exceeded the PAL $(320,000 \mu \mathrm{g} / \mathrm{kg})$. No other COCs were identified above PALs as specified in the CAIP; therefore, potential corrective actions will be identified and evaluated in this CADD to ensure worker, public, 
CAU 342 CADD

Section: 2.0

Revision: 1

Date: $05 / 27 / 99$

Page 9 of 35

and environmental protection against potential exposure to the TPH and related xylene contamination in accordance with NAC 445A (NAC, 1996b). 


\subsection{Evaluation of Alternatives}

The purpose of this section is to present the corrective action objectives for CAU 342, describe the general standards and decision factors used to screen the corrective action alternatives, and develop and evaluate a set of corrective action alternatives that could be used to meet the corrective action objectives.

\subsection{Corrective Action Objectives}

The corrective action objectives are media-specific goals for protecting human health and the environment. Based on the potential exposure pathways (see Section 3.1.2), the following corrective action objectives have been identified for CAU 342:

- Prevent or mitigate exposure to surface, near-surface, and subsurface soil containing COCs at concentrations exceeding PALs (DOE/NV, 1998).

- Prevent adverse impacts to groundwater quality.

\subsubsection{Contaminants of Concern}

Contaminants of potential concern were determined in the Data Quality Objective (DQO) process as listed in the CAIP (DOE/NV, 1998). Analytical results obtained from the corrective action investigation were evaluated to determine if COPCs were detected above PALs, and would therefore be COCs for CAU 342 that must be addressed by corrective action. Based on the results of this evaluation, elevated levels of petroleum hydrocarbons and xylene (associated with the petroleum hydrocarbons) identified them as COCs. No other COCs were identified.

\subsubsection{Potential Exposure Pathways}

Based on the Final Environmental Impact Statement for the Nevada Test Site and Off-Site Locations in the State of Nevada (DOE/NV, 1996a) and the Record of Decision: Environmental Impact Statement for the Nevada Test Site and Off-Site Locations in the State of Nevada (DOE/NV, 1996c), the future use of the FTP area may include support for short-term nondefense research, testing, experimentation, and training. These potential future uses would likely require limited excavation of the contaminated soil by site workers. Groundwater at the site is estimated to be greater than $800 \mathrm{ft}$ 
below ground surface (bgs) and the environmental conditions at the site (i.e., arid climate, low permeabilities) are not conducive to downward migration (Winograd and Thordarson, 1975). Therefore, groundwater exposure to COCs is not considered to be a pathway (refer to Section 3.3 for a detailed [a-k] evaluation).

\subsection{Screening Criteria}

The screening criteria used to evaluate and select the preferred corrective action alternatives are identified in the U.S. Environmental Protection Agency's (EPA) Guidance on Resource Conservation and Recovery Act (RCRA) Corrective Action Decision Documents (EPA, 1991) and the Final RCRA Corrective Action Plan (EPA, 1994).

Corrective action alternatives will be evaluated based on four general corrective action standards and five remedy selection decision factors. All corrective action alternatives must meet the general standards to be selected for evaluation using the remedy selection decision factors.

The general corrective action standards are:

- Protection of human health and the environment

- Compliance with media cleanup standards

- Control the source(s) of the release

- Compliance with applicable federal, state, and local standards for waste management

The remedy selection decision factors are:

- Short-term reliability and effectiveness

- Reduction of toxicity, mobility, and/or volume

- Long-term reliability and effectiveness

- Feasibility

- Cost

\subsubsection{Corrective Action Standards}

The following text describes the corrective action standards used to evaluate the corrective action alternatives. 


\section{Protection of Human Health and the Environment}

Protection of human health and the environment is a general mandate of the RCRA statute (EPA, 1994). This mandate requires that the corrective action include any protective measures that are needed. These measures may or may not be directly related to media cleanup, source control, or management of wastes. The corrective action alternatives are evaluated for the ability to meet corrective action objectives as defined in Section 3.1.

\section{Compliance with Media Cleanup Standards}

Each corrective action alternative must have the ability to meet the proposed media cleanup standards as set forth in applicable state and federal regulations (445A.2272 [NAC, 1996b]). This regulation prescribes an appropriate concentration that is based on the protection of public health and safety and the environment. The appropriate level must be based on the Integrated Risk Information System. For this CAU, the EPA's Region IX Preliminary Remediation Goals, which are derived from the Integrated Risk Information System, are the basis for establishing the PALs. The PALs were established during the DQO process and are presented in the CAIP.

\section{Control the Source(s) of the Release}

An objective of a corrective action remedy is to stop further environmental degradation by controlling or eliminating additional releases that may pose a threat to human health and the environment. Unless source control measures are taken, efforts to clean up releases may be ineffective or, at best, will essentially involve a perpetual cleanup. Therefore, each corrective action alternative must use an effective source control program to ensure the long-term effectiveness and protectiveness of the corrective action.

\section{Comply with Applicable Federal, State, and Local Standards for Waste Management}

During implementation of any corrective action alternative, all waste management activities must be conducted in accordance with applicable state and federal regulations (e.g., Nevada Revised Statutes [NRS] 459.400 - 459.600 [NRS, 1995]; RCRA 40 CFR 260 - 282, "RCRA Regulations” [CFR, 1998]; NAC 444, "Solid Waste Disposal" [NAC, 1996a]; and NAC 459.9974, "Disposal and Evaluation of Contaminated Soil" [NAC, 1996c]). The requirements for management of the waste, if any, derived from the corrective action will be determined based on applicable state and federal regulations, field observations, process knowledge, characterization data, and data collected and 
analyzed during corrective action implementation. Administrative controls (e.g., decontamination procedures and corrective action strategies) will minimize waste generated during site corrective action activities. Decontamination activities will be performed in accordance with approved procedures and will be designated according to the COCs present at the site.

\subsubsection{Remedy Selection Decision Factors}

The following paragraphs describe the remedy selection decision factors used to evaluate the corrective action alternatives.

\section{Short-Term Reliability and Effectiveness}

Each corrective action alternative must be evaluated with respect to its effects on human health and the environment during the construction and implementation of the corrective action. The following factors will be addressed for each alternative:

- Protection of the community from potential risks associated with implementation such as fugitive dusts, transportation of hazardous materials, explosion

- Protection of workers during construction and implementation

- Environmental impacts that may result from construction and implementation

- The amount of time until the corrective action objectives are achieved

\section{Reduction of Toxicity, Mobility, and/or Volume}

Each corrective action alternative must be evaluated for its ability to reduce the toxicity, mobility, and/or volume of the contaminated media. Reduction in toxicity, mobility, and/or volume refers to changes in one or more characteristics of the contaminated media by the use of corrective measures that decrease the inherent threats associated with that media.

\section{Long-Term Reliability and Effectiveness}

Each corrective action alternative must be evaluated in terms of risk remaining at the CAU after the corrective action alternative has been implemented. The primary focus of this evaluation is on the extent and effectiveness of the controls that may be required to manage risk posed by treatment residuals and/or untreated wastes. 


\section{Feasibility}

The feasibility criterion addresses the technical and administrative feasibility of implementing a corrective action alternative and the availability of services and materials needed during implementation. Each corrective action alternative must be evaluated for the following criteria:

- Construction and Operation: This refers to the feasibility of implementing a corrective action alternative given the existing set of waste and site-specific conditions.

- Administrative Feasibility: This refers to the administrative activities needed to implement the corrective action alternative (e.g., permits, public acceptance, rights of way, off-site approval).

- Availability of Services and Materials: This refers to the availability of adequate off-site and on-site treatment, storage capacity, disposal services, necessary technical services and materials, and availability of prospective technologies for each corrective action alternative.

\section{Cost}

Costs for each alternative are estimated for comparison purposes only. The cost estimate for each corrective action alternative includes both capital and operation and maintenance costs, as applicable. The following is a brief description of each component:

- Capital Costs: These costs include both direct and indirect costs. Direct costs may consist of materials, labor, mobilization, demobilization, site preparation, construction materials, equipment purchase and rental, sampling and analysis, waste disposal, and health and safety measures. Indirect costs include such items as engineering design, permits and/or fees, start-up costs, and any contingency allowances.

- Operation and Maintenance: These costs include labor, training, sampling and analysis, maintenance materials, utilities, and health and safety measures.

Cost summaries for this CADD are provided in Appendix D.

\subsection{Development of Corrective Action Alternatives}

This section identifies and briefly describes the viable corrective action technologies and the corrective action alternatives considered for the affected media. Based on the review of existing data, 
future use, and current operations at the NTS, the following alternatives have been developed for consideration at CAU 342:

- Alternative 1 - No Further Action

- Alternative 2 - Closure in Place with Partial Excavation, Disposal, and Administrative Controls

- Alternative 3 - Partial Excavation, Disposal, In Situ Bioremediation, and Administrative Controls

- Alternative 4 - Partial Excavation, Disposal, and Monitoring

Other alternatives such as complete removal of COCs and administrative controls were considered. However, complete removal was considered unnecessary due to limited nature and extent of COCs and administrative controls alone were deemed not to be protective due to the presence of surface contamination and potential future uses of the site.

The following evaluation of NAC 445A.227 (2) (a-k) (NAC, 1996b) supports the protection of groundwater from CAU 342 COCs:

a. The depth to groundwater is approximately 800 to $1,100 \mathrm{ft}$ below land surface in Mercury Valley (Winograd and Thordarson, 1975; Robie et al., 1995). Field screening and analytical data indicate that COCs at the FTP extend less than $50 \mathrm{ft}$ bgs.

b. The distance to the nearest water-supply well Army Well \#1, is approximately 5 mi southwest of the FTP (La Camera and Westenberg, 1994). Army Well \#1 is a back-up drinking water supply for Mercury, Nevada. The groundwater flow direction is generally to the southwest (Laczniak et al., 1996).

c. Soils at the FTP are gravelly sands and sandy gravels with lenses of sands and gravels with significant silt and clay. Caliche layers between a few inches and a few feet thick correlate with underlying zones of lower TPH field screening. Geotechnical samples demonstrate that permeability generally decreases with increasing depth. Permeability values decreased from a high of $3.20 \times 10^{-4}$ centimeters per second $(\mathrm{cm} / \mathrm{sec})$ measured at $5 \mathrm{ft}$ bgs to a low of $3.59 \times 10^{-6} \mathrm{~cm} / \mathrm{sec}$ measured at $50 \mathrm{ft}$ bgs. The caliche layers and decreasing permeability with greater depth limit downward migration of COCs.

d. Average annual precipitation for valleys in the South-Central Great Basin range from 3 to 6 inches (in.) (Winograd and Thordarson, 1975). Precipitation events are ephemeral and highly variable in the arid environment. Annual evaporation is roughly 5 to 25 times the 
annual precipitation (Winograd and Thordarson, 1975). The high evaporation low precipitation rates create a negative water balance for the area; therefore, there is no sufficient driving force at the FTP that would aid in mobilizing COCs beyond current depths.

e. The COCs released are hydrocarbon compounds including diesel, waste oil, gasoline, unknown hydrocarbons, and xylene (associated with the petroleum hydrocarbons).

f. The vertical extent of contamination based on field screening and analytical data indicate that COCs are confined to within $50 \mathrm{ft}$ of the land surface. Surface contamination includes areas of 16,300 square feet $\left(\mathrm{ft}^{2}\right)$ and $5,830 \mathrm{ft}^{2}$ and three areas with much less vertical and lateral extent.

g. Presently the CAU is located in a government-controlled facility and future land use will likely remain the same. The NTS is a restricted area guarded continuously throughout the year. Access is limited to authorized personnel. Fire suppression training at the FTP ended in 1992 and the facility is currently inactive. Future use of the FTP area may include support for short-term nondefense research, testing, experimentation, and training.

h. Preferred routes of migration are limited since the point sources of the COCs have been removed. Vertical migration of the COCs is unlikely because of a lack of driving forces and generally decreasing permeability with increasing depth. Limited downward migration of COCs driven by ponding of precipitation within the burn pit is possible. The burn pit is surrounded by a low berm ranging from $2 \mathrm{in}$. to $10 \mathrm{in}$. high, and enclosing a 1,755 $\mathrm{ft}^{2}$ area. Standing water is unlikely for the remainder of the FTP because the site is well drained by adjacent stream drainages. Lateral migration of COCs could be produced by precipitation runoff from the FTP surface contamination areas. Contact with surface contamination or contact with subsurface contamination due to inadvertent intrusion are the pathways from the contamination to potential receptors.

i. Surface structures and debris were removed prior to investigation activities.

j. The potential hazards related to fire, vapor, or explosion are very low because the highest TPH concentrations are located below the land surface.

k. The ASTs have been removed mitigating additional contaminants from being released into the subsurface. No other site-specific factors are known at this time.

\subsubsection{Alternative 1 - No Further Action}

Under the No Further Action Alternative, no corrective action activities will be implemented. This alternative is used as a starting point to establish a baseline for comparison with the other corrective action alternatives. This alternative does not meet the corrective action objectives because no actions 
are taken to prevent human contact with the surface and subsurface contamination. This alternative will not be compared to the other alternatives using the selection decision factors.

\subsubsection{Alternative 2 - Closure in Place with Partial Excavation, Disposal, and Administrative Controls}

This alternative consists of removing portions of the TPH contaminated soil from the source areas and areas where surface contamination has been identified (see Figure 3-1). The contaminated soil will then be disposed of in an appropriate disposal facility. Soil analyses indicate that soil within the burn pit may be hazardous (exceed the maximum concentration for the toxicity characteristic for cadmium).

The point source areas will be excavated to an approximate depth of $5 \mathrm{ft}$. The surrounding and downgradient contaminated surface soils will be excavated to an approximate depth of $1 \mathrm{ft}$. These areas are indicated in Figure 3-1. The remaining voids will be backfilled with clean borrow soil. The site will then be graded and compacted to ambient conditions to minimize inadvertent intrusion, by burrowing animals, prevent ponding, and promote surface drainage.

The areas with TPH contamination greater than $10,000 \mathrm{mg} / \mathrm{kg}$ will be excavated using a $81 / 2 \mathrm{ft}$ diameter auger. Proposed auger locations are shown in Figure 3-2. Each auger location will be advanced to $5 \mathrm{ft}$ below the depth where TPH concentrations exceeded 10,000 $\mathrm{mg} / \mathrm{kg}$. Verification samples will be collected from the bottom of each auger location to determine remaining TPH concentrations. Step-out locations may be augered if verification samples indicate that TPH concentrations greater than $10,000 \mathrm{mg} / \mathrm{kg}$ remain. The remaining voids will be backfilled with clean borrow soil.

Administrative controls will also be implemented under this alternative to prevent inadvertent contact with subsurface contaminated media. These controls would consist of use restrictions to prevent unauthorized intrusive activities. The future use of the area associated with this CAU would be restricted from any activity that would alter or modify the containment control unless appropriate concurrence was obtained from NDEP. Based on the bioassessment for the site, the existing conditions are favorable to natural biological degradation (i.e., no enhancements applied). Natural 


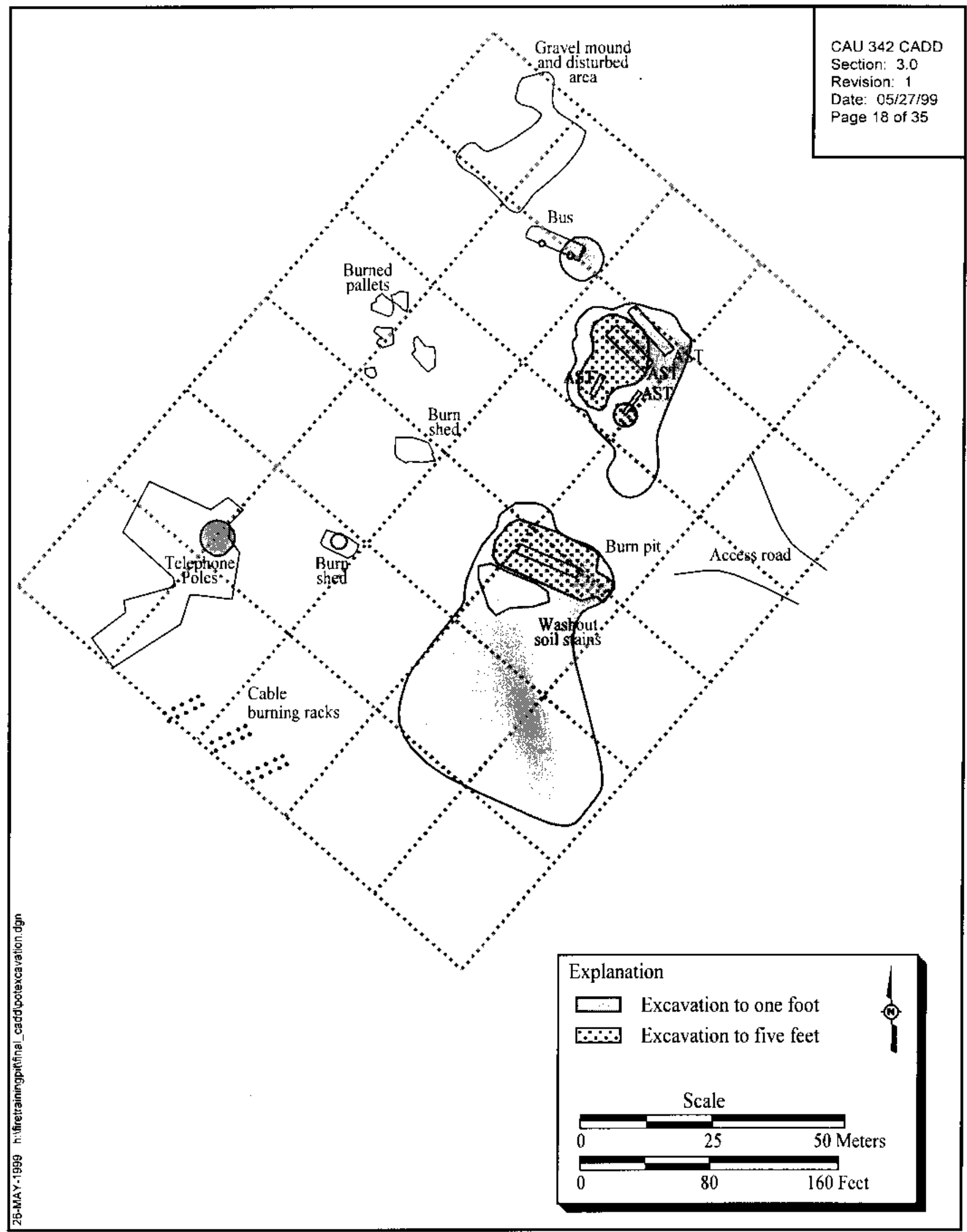

Figure 3-1

Potential Areas of Excavation, Area 23 Mercury Fire Training Pit, Nevada Test Site 


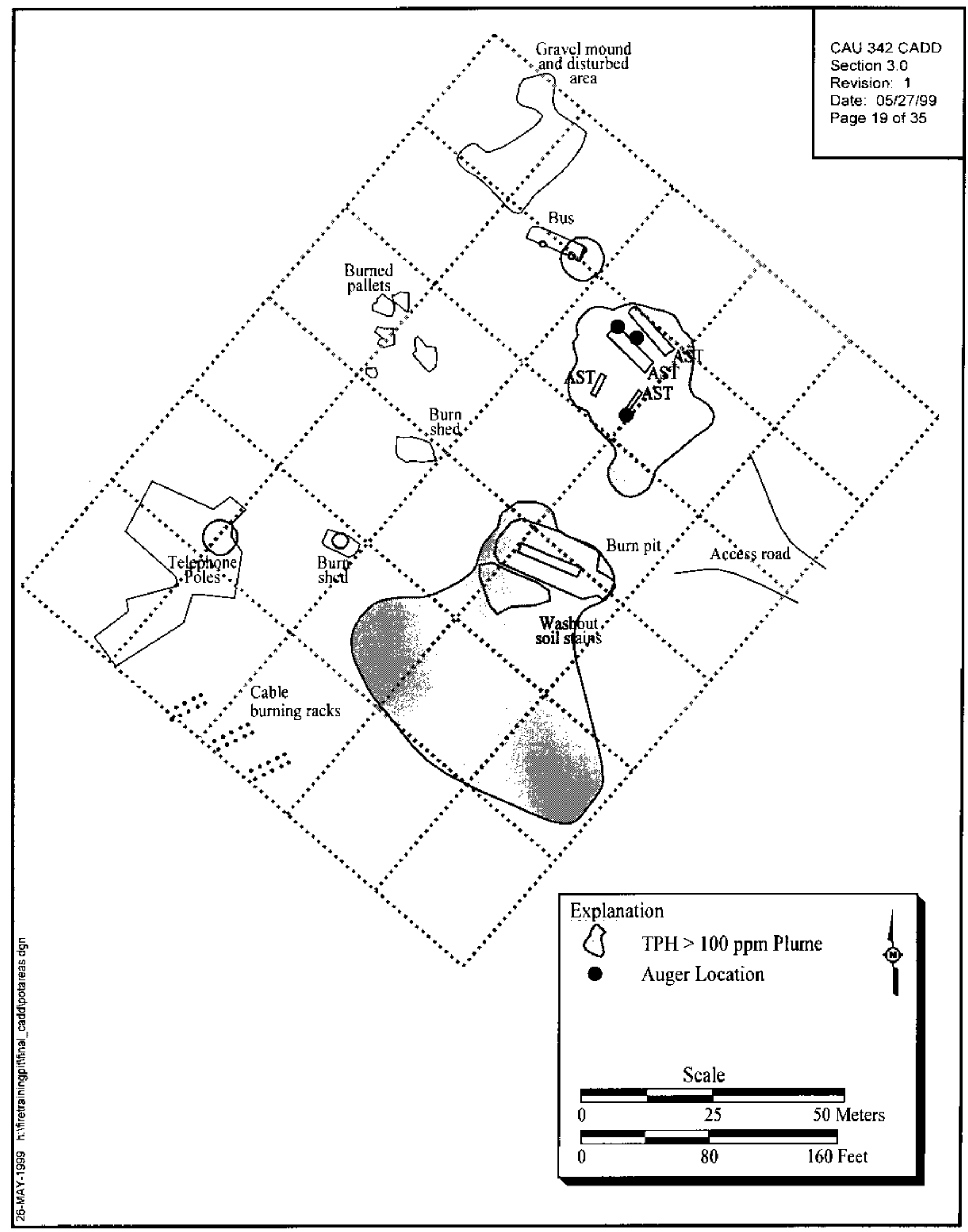

Figure 3-2

Potential Auger Locations, Area 23 Mercury Fire Training Pit, Nevada Test Site 
biological activity will result in reduced concentrations of hydrocarbons with time. The bioassessment report is in Appendix E.

Administrative controls are commonly used and can effectively eliminate potential exposure pathways. Administrative controls are effective because the NTS is a restricted access facility. The implementation of administrative controls requires the coordination of all entities at a facility to ensure that the restrictions are enforced. An evaluation of NAC 445A.227 (2)(a-k) (NAC, 1996b) requirements is presented in Section 3.3. This evaluation provides support that the conditions at the CAU will not adversely impact the groundwater beneath the CAU or any nearby drinking water wells.

\subsubsection{Alternative 3 - Partial Excavation, Disposal, In Situ Bioremediation and Administrative Controls}

Alternative 3 consists of removing portions of the TPH contaminated soil from the source areas and areas where surface contamination has been identified. The point source areas will be excavated to an approximate depth of $5 \mathrm{ft}$. The surrounding and downgradient contaminated surface soils will be excavated to an approximate depth of $1 \mathrm{ft}$. These areas are indicated in Figure 1-1. The remaining voids will be backfilled with clean borrow soil. The site will then be graded and compacted to ambient conditions to minimize inadvertent intrusion, by burrowing animals, prevent ponding, and promote surface drainage.

Remaining source plume subsurface TPH concentrations will be reduced via in situ bioremediation. The analysis of microbial parameters at the site indicated favorable conditions for bioremediation with minimal need for added components (Appendix E). Because of the relatively small plume sizes, a simplified system could be employed to provide oxygen to the contaminated zone to stimulate biological activity. This system would consist of approximately five wells. Both the burn pit plume and the AST storage area plumes would have two or three vadose zone wells; at least one of the vadose zone wells would be an extraction well with a wind-powered (other power options such as electricity could also be used) turbine to induce a pressure differential across the plume. The system would be designed to limit air emissions. An open well opposite this extraction well would allow air flow in the plume and serve as a monitoring port. Fencing would be installed to protect the bioremediation well system and prevent inadvertent contact with contaminated subsurface soil until 
concentrations could be adequately reduced. Gas samples from the system would be periodically collected to monitor respiration rates. As bioremediation progresses, injection of additional nutrients may be required. These would be introduced through the open wells. The exact system configuration and monitoring scheme would be developed in the Corrective Action Plan. With time, the bioremediation system could result in reduction of TPH to preliminary action levels. A respiration test would be necessary to more accurately estimate the length of time and number of wells necessary for adequate effectiveness. After remediation, the wells would be closed in accordance with State of Nevada requirements.

Administrative controls will also be implemented under this alternative to prevent inadvertent contact with subsurface contaminated media. These controls would consist of use restrictions to prevent unauthorized intrusive activities. The future use of the area associated with this CAU would be restricted from any activity that would alter or modify the containment control unless appropriate concurrence was obtained from NDEP.

\subsubsection{Alternative 4 - Partial Excavation, Disposal, Monitoring, and Administrative Controls}

Alternative 4 consists of removing surface and shallow, subsurface contamination and monitoring the natural attenuation of the remaining source plume subsurface TPH concentrations. The analysis of microbial parameters at the site indicated favorable conditions for bioremediation with minimal need for added components.

This alternative consists of removing portions of the TPH contaminated soil from the source areas and areas where surface contamination has been identified. The point source areas will be excavated to an approximate depth of $5 \mathrm{ft}$. The surrounding and downgradient contaminated surface soils will be excavated to an approximate depth of $1 \mathrm{ft}$. These areas are indicated in Figure 1-1. The remaining voids will be backfilled with clean borrow soil. The site will then be graded and compacted to ambient conditions to minimize inadvertent intrusion, by burrowing animals, prevent ponding, and promote surface drainage.

A gas sampling system will be installed. Soil gas samples will be collected at one location to determine ambient conditions and degradation rate. The approximate location for the gas sample well 
is shown on Figure 3-3. The actual well location will be determined by site conditions at the time of installation. Samples will be field screened for oxygen, carbon dioxide, methane, and VOCs. Gas samples will be collected for laboratory analysis for total VOCs and total SVOCs. Biannual sampling will be conducted for three sampling events or a total of six years. The data will be evaluated at the end of the six-year monitoring period to determine what additional actions are required at the site. If the natural degradation rate is determined to be sufficient to reduce the concentrations of COCs below $100 \mathrm{mg} / \mathrm{kg}$ in 30 years no bioremediation system will be installed.

Verification of in situ biodegradation will be based on the following techniques:

- Metabolic by-products. The production of, or an increase in the concentrations of known by-products of microbial activity, such as carbon dioxide, will be used as a biodegradation indicator (NRC, 1993).

- Intermediary metabolites. The presence of metabolic intermediaries, simpler but incompletely degraded forms of the contaminants, will be used as a biodegradation indicator (NRC, 1993).

- Growth-stimulating materials. A depletion of the concentration of growth-stimulating materials, such as oxygen or other electron acceptors, will be used as a biodegradation indicator (NRC, 1993).

- Ratio of nondegradable to degradable compounds. An increase in the the ratio of compounds that are difficult to degrade to those that are easily degradable will be used as a biodegradation indicator (NRC, 1993).

Administrative controls will also be implemented under this alternative to prevent inadvertent contact with subsurface contaminated media. These controls would consist of use restrictions to prevent unauthorized intrusive activities. The future use of the area associated with this CAU would be restricted from any activity that would alter or modify the containment control unless appropriate concurrence was obtained from NDEP. Based on the bioassessment for the site, the existing conditions are favorable to natural biological degradation (i.e., no enhancements applied). Natural biological activity will result in reduced concentrations of hydrocarbons with time. The bioassessment report is in Appendix E.

Administrative controls are commonly used and can effectively eliminate potential exposure pathways. Administrative controls are effective because the NTS is a restricted access facility. The 


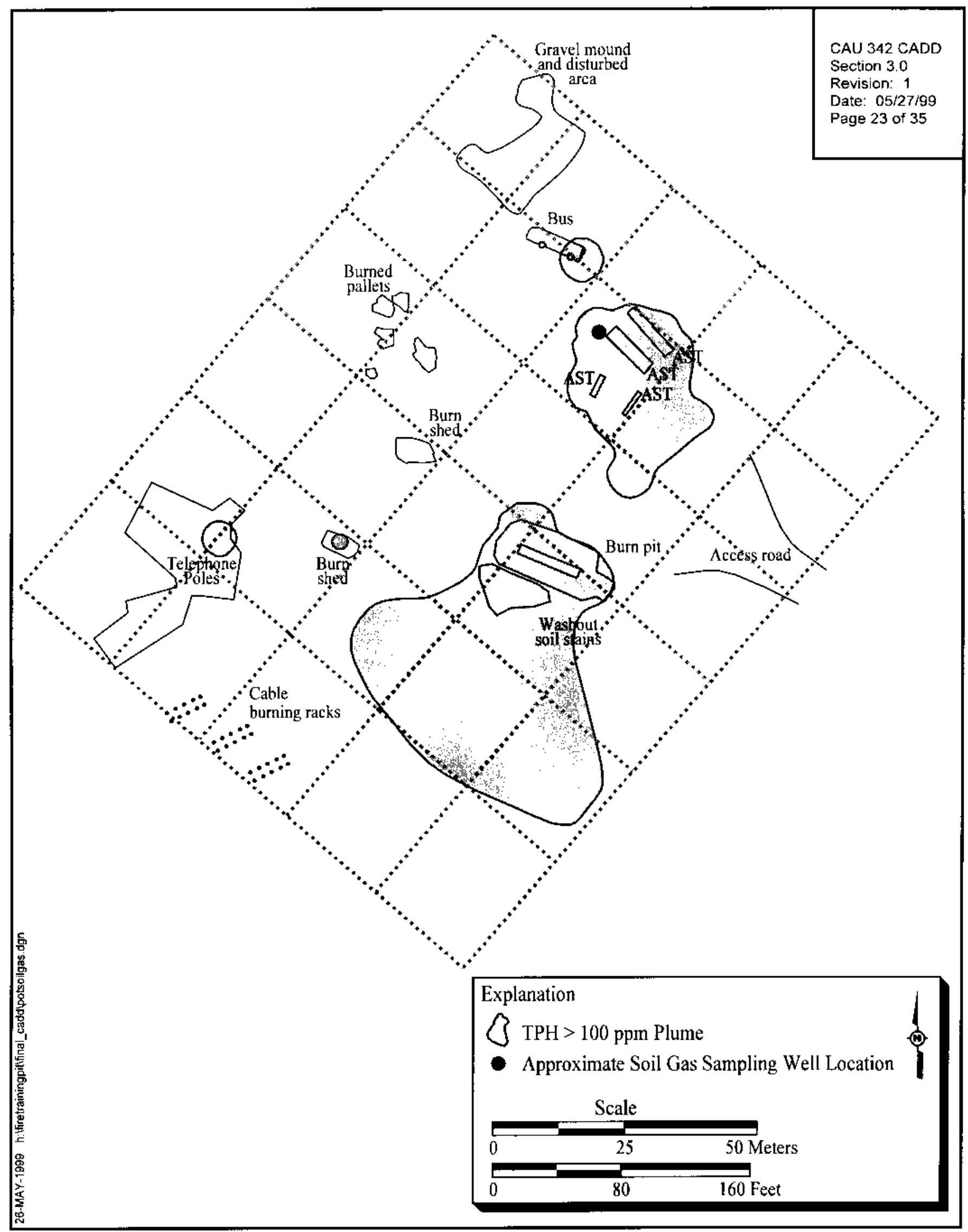

Figure 3-3

Potential Soil Gas Sampling Well Location 
implementation of administrative controls requires the coordination of all entities at a facility to ensure that the restrictions are enforced. An evaluation of NAC 445A.227 (2)(a-k) (NAC, 1996b) requirements is presented in Section 3.3. This evaluation provides support that the conditions at the CAU will not adversely impact the groundwater beneath the CAU or any nearby drinking water wells.

\subsection{Evaluation and Comparison of Alternatives}

The general corrective action standards and remedy selection decision factors described in Section 3.2 were used to conduct detailed and comparative analyses of each corrective action alternative. The advantages and disadvantages of each alternative were assessed to select a preferred alternative for CAU 342. Table 3-1 presents a summary of the detailed analysis of the alternatives. Table 3-2 presents the comparative analysis of alternatives. A summary of the costs for the alternatives is provided in Appendix D 
Table 3-1

Detailed Evaluation of Alternatives

(Page 1 of 6 )

\begin{tabular}{|c|c|c|c|c|}
\hline Evaluation Criteria & $\begin{array}{c}\text { Alternative } 1 \\
\text { No Further Action }\end{array}$ & $\begin{array}{c}\text { Alternative } 2 \\
\text { Closure in Place with Partial } \\
\text { Excavation, Disposal, and } \\
\text { Administrative Controls }\end{array}$ & $\begin{array}{c}\text { Alternative 3 } \\
\text { Partial Excavation, Disposal, In } \\
\text { Situ Bioremediation, and } \\
\text { Administrative Controls }\end{array}$ & $\begin{array}{c}\text { Alternative 4 } \\
\text { Partial Excavation, Disposal, } \\
\text { Monitoring, and Administrative } \\
\text { Controls }\end{array}$ \\
\hline \multicolumn{5}{|c|}{ Closure Standards } \\
\hline $\begin{array}{l}\text { Protection of Human } \\
\text { Health and the } \\
\text { Environment }\end{array}$ & $\begin{array}{l}\text { Does not meet corrective } \\
\text { action objective of preventing } \\
\text { exposure to the contaminated } \\
\text { soil zone. } \\
\text { Contaminants not impacting } \\
\text { groundwater as shown by } \\
\text { NAC } 445 A .227(2)(a-k) \\
\text { analysis. } \\
\text { No worker exposure } \\
\text { associated with } \\
\text { implementation. }\end{array}$ & 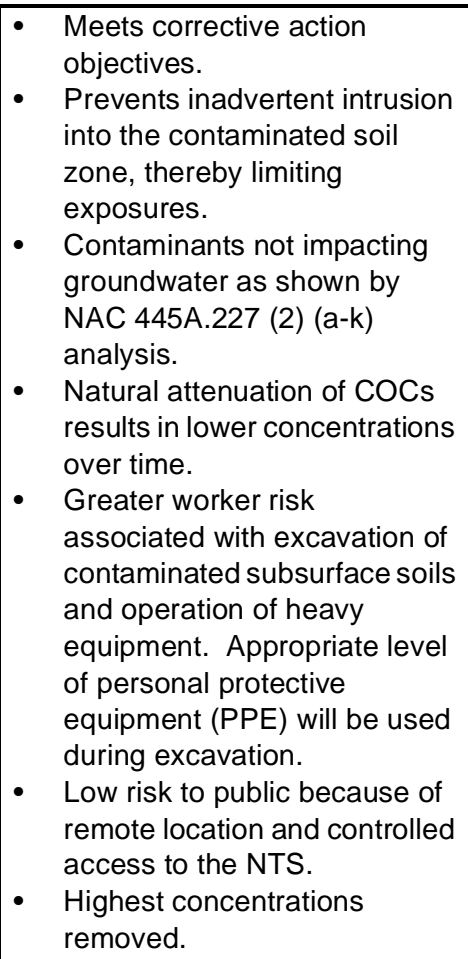 & 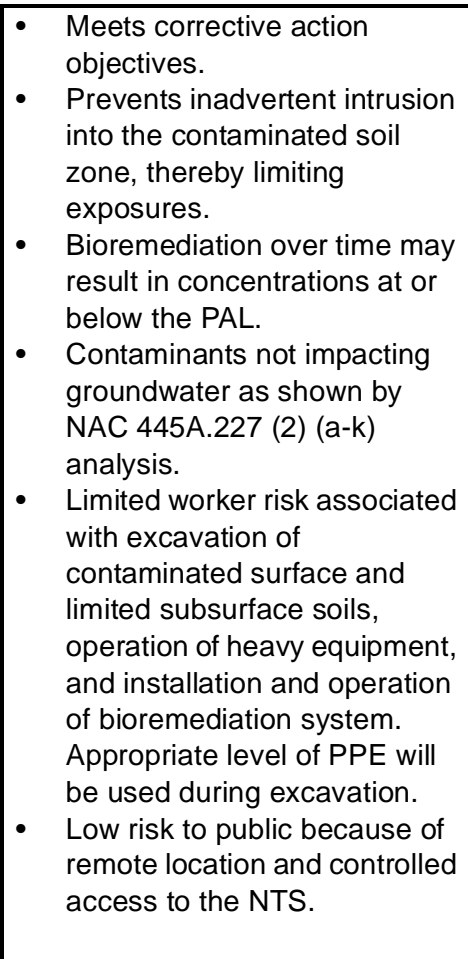 & 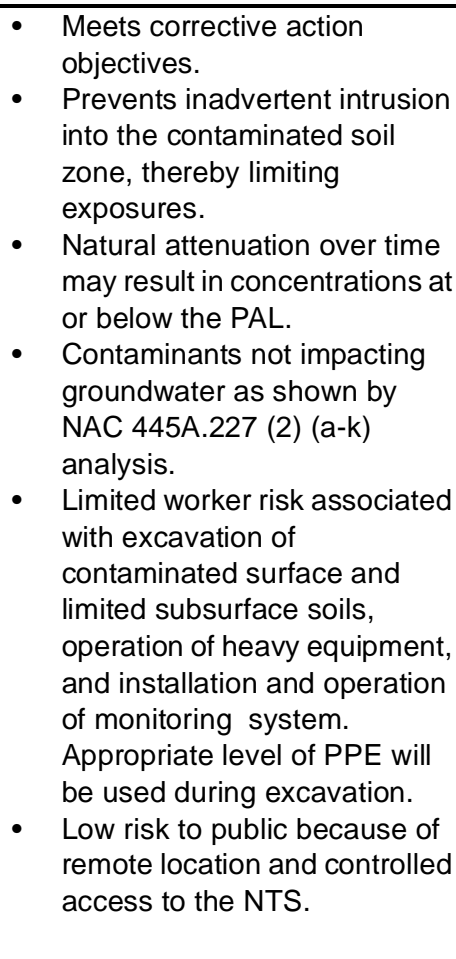 \\
\hline
\end{tabular}


Table 3-1

Detailed Evaluation of Alternatives

(Page 2 of 6 )

\begin{tabular}{|c|c|c|c|c|}
\hline Evaluation Criteria & $\begin{array}{c}\text { Alternative } 1 \\
\text { No Further Action }\end{array}$ & $\begin{array}{c}\text { Alternative } 2 \\
\text { Closure in Place with Partial } \\
\text { Excavation, Disposal, and } \\
\text { Administrative Controls }\end{array}$ & $\begin{array}{c}\text { Alternative } 3 \\
\text { Partial Excavation, Disposal, In } \\
\text { Situ Bioremediation, and } \\
\text { Administrative Controls }\end{array}$ & $\begin{array}{c}\text { Alternative 4 } \\
\text { Partial Excavation, Disposal, } \\
\text { Monitoring, and Administrative } \\
\text { Controls }\end{array}$ \\
\hline \multicolumn{5}{|c|}{ Closure Standards } \\
\hline $\begin{array}{l}\text { Compliance with Media } \\
\text { Cleanup Standards }\end{array}$ & $\begin{array}{l}\text { Does not comply with media } \\
\text { cleanup standards because } \\
\text { COCs remain at levels above } \\
\text { PALs, and no corrective action } \\
\text { is taken to prevent exposure } \\
\text { through inadvertent intrusion. } \\
\text { - No action implemented to } \\
\text { close the FTP. } \\
\text { Contaminants not impacting } \\
\text { groundwater as shown by } \\
\text { NAC 445A.227 (2) (a-k) } \\
\text { analysis. }\end{array}$ & $\begin{array}{l}\text { Complies with media cleanup } \\
\text { standards by removing } \\
\text { contaminated surface and } \\
\text { subsurface soils and } \\
\text { eliminating exposure } \\
\text { pathways. } \\
\text { - Natural attenuation of COC } \\
\text { results in lower concentrations } \\
\text { over time. } \\
\text { Exposure to the contaminated } \\
\text { soil through intrusive activities } \\
\text { is controlled. } \\
\text { Contaminants not impacting } \\
\text { groundwater as shown by } \\
\text { NAC 445A.227 (2) (a-k) } \\
\text { analysis. }\end{array}$ & $\begin{array}{l}\text { Complies with media cleanup } \\
\text { standards by removing } \\
\text { contaminated surface soils } \\
\text { and eliminating exposure } \\
\text { pathways. } \\
\text { - Concentrations may be } \\
\text { reduced to PAL level over } \\
\text { time by the bioremediation. } \\
\text { Contaminants not impacting } \\
\text { groundwater as shown by } \\
\text { NAC 445A.227 (2) (a-k) } \\
\text { analysis. }\end{array}$ & $\begin{array}{l}\text { - Complies with media cleanup } \\
\text { standards by removing } \\
\text { contaminated surface soils } \\
\text { and eliminating exposure } \\
\text { pathways. } \\
\text { - Concentrations may be } \\
\text { reduced to PAL level over } \\
\text { time by natural attenuation. } \\
\text { Contaminants not impacting } \\
\text { groundwater as shown by } \\
\text { NAC } 445 A .227 \text { (2) (a-k) } \\
\text { analysis. } \\
\text { A monitoring system will be } \\
\text { installed to verify natural } \\
\text { attenuation. }\end{array}$ \\
\hline $\begin{array}{l}\text { Control the Source(s) of } \\
\text { Release }\end{array}$ & $\begin{array}{l}\text { - Training exercises are no } \\
\text { longer conducted at the FTP. } \\
\text { The site elements (e.g., tanks, } \\
\text { bus, and structures) have } \\
\text { been removed. } \\
\text { The source(s) for release of } \\
\text { cOCs to the environment are } \\
\text { no longer viable. }\end{array}$ & $\begin{array}{l}\text { - Training exercises are no } \\
\text { longer conducted at the FTP. } \\
\text { The site elements (e.g., tanks, } \\
\text { bus, and structures) have } \\
\text { been removed. } \\
\text { The source(s) for release of } \\
\text { COCs to the environment are } \\
\text { no longer viable. } \\
\text { Contaminated surface and the } \\
\text { most highly contaminated } \\
\text { subsurface soils will be } \\
\text { removed to limit migration of } \\
\text { COCs to uncontaminated } \\
\text { areas. }\end{array}$ & $\begin{array}{l}\text { - Training exercises are no } \\
\text { longer conducted at the FTP. } \\
\text { The site elements (e.g., tanks, } \\
\text { bus, and structures) have } \\
\text { been removed. } \\
\text { The source(s) for release of } \\
\text { COCs to the environment are } \\
\text { no longer viable. } \\
\text { Contaminated surface and } \\
\text { limited subsurface soils will be } \\
\text { removed to limit migration of } \\
\text { COCs to uncontaminated } \\
\text { areas. }\end{array}$ & $\begin{array}{l}\text { Training exercises are no } \\
\text { longer conducted at the FTP. } \\
\text { The site elements (e.g., tanks, } \\
\text { bus, and structures) have } \\
\text { been removed. } \\
\text { The source(s) for release of } \\
\text { cOCs to the environment are } \\
\text { no longer viable. } \\
\text { Contaminated surface and } \\
\text { limited subsurface soils will be } \\
\text { removed to limit migration of } \\
\text { cOCs to uncontaminated } \\
\text { areas. }\end{array}$ \\
\hline
\end{tabular}


Table 3-1

Detailed Evaluation of Alternatives

(Page 3 of 6)

\begin{tabular}{|c|c|c|c|c|}
\hline Evaluation Criteria & $\begin{array}{c}\text { Alternative } 1 \\
\text { No Further Action }\end{array}$ & $\begin{array}{c}\text { Alternative } 2 \\
\text { Closure in Place with Partial } \\
\text { Excavation, Disposal, and } \\
\text { Administrative Controls }\end{array}$ & $\begin{array}{c}\text { Alternative } 3 \\
\text { Partial Excavation, Disposal, In } \\
\text { Situ Bioremediation, and } \\
\text { Administrative Controls }\end{array}$ & $\begin{array}{c}\text { Alternative } 4 \\
\text { Partial Excavation, Disposal, } \\
\text { Monitoring, and Administrative } \\
\text { Controls }\end{array}$ \\
\hline \multicolumn{5}{|c|}{ Closure Standards } \\
\hline $\begin{array}{l}\text { Comply with Applicable } \\
\text { Federal, State, and Local } \\
\text { Standards for Waste } \\
\text { Management }\end{array}$ & No waste generated & $\begin{array}{l}\text { Potentially characteristic } \\
\text { hazardous waste associated } \\
\text { with leachable cadmium } \\
\text { contamination at the burn pit } \\
\text { will be handled and disposed } \\
\text { of in compliance with } \\
\text { applicable regulations. } \\
\text { Other wastes, such as } \\
\text { hydrocarbon contaminated } \\
\text { soil, will be disposed } \\
\text { according to applicable } \\
\text { regulations in an appropriate } \\
\text { disposal facility. }\end{array}$ & $\begin{array}{l}\text { Potentially characteristic } \\
\text { hazardous waste associated } \\
\text { with leachable cadmium } \\
\text { contamination at the burn pit } \\
\text { will be handled and disposed } \\
\text { of in compliance with } \\
\text { applicable regulations. } \\
\text { Other wastes, such as } \\
\text { hydrocarbon contaminated } \\
\text { soil, will be disposed } \\
\text { according to applicable } \\
\text { regulations in an appropriate } \\
\text { disposal facility. }\end{array}$ & $\begin{array}{l}\text { Potentially characteristic } \\
\text { hazardous waste associated } \\
\text { with leachable cadmium } \\
\text { contamination at the burn pit } \\
\text { will be handled and disposed } \\
\text { of in compliance with } \\
\text { applicable regulations. } \\
\text { Other wastes, such as } \\
\text { hydrocarbon contaminated } \\
\text { soil, will be disposed } \\
\text { according to applicable } \\
\text { regulations in an appropriate } \\
\text { disposal facility. }\end{array}$ \\
\hline
\end{tabular}


Table 3-1

Detailed Evaluation of Alternatives

(Page 4 of 6 )

\begin{tabular}{|c|c|c|c|c|}
\hline Evaluation Criteria & $\begin{array}{c}\text { Alternative } 1 \\
\text { No Further Action }\end{array}$ & $\begin{array}{c}\text { Alternative } 2 \\
\text { Closure in Place with Partial } \\
\text { Excavation, Disposal, and } \\
\text { Administrative Controls }\end{array}$ & $\begin{array}{c}\text { Alternative } 3 \\
\text { Partial Excavation, Disposal, In } \\
\text { Situ Bioremediation, and } \\
\text { Administrative Controls }\end{array}$ & $\begin{array}{c}\text { Alternative } 4 \\
\text { Partial Excavation, Disposal, } \\
\text { Monitoring, and Administrative } \\
\text { Controls }\end{array}$ \\
\hline \multicolumn{5}{|c|}{ Closure Standards } \\
\hline \multicolumn{5}{|c|}{ Remedy Selection Decision Factors } \\
\hline $\begin{array}{l}\text { Short-Term Reliability and } \\
\text { Effectiveness }\end{array}$ & Not evaluated & $\begin{array}{l}\text { - Limited worker risk associated } \\
\text { with excavation and disposal } \\
\text { of contaminated surface and } \\
\text { subsurface soils through } \\
\text { exposure to COCs and } \\
\text { operation of heavy equipment. } \\
\text { Appropriate level of PPE will } \\
\text { be used during excavation. } \\
\text { - Limited environmental impact } \\
\text { during alternative } \\
\text { implementation because } \\
\text { removal areas are previously } \\
\text { disturbed and sparsely } \\
\text { vegetated. } \\
\text { Public protected by remote } \\
\text { location and NTS site access } \\
\text { controls. } \\
\text { Risks associated with } \\
\text { transportation minimized by } \\
\text { disposing of excavated } \\
\text { nonhazardous contaminated } \\
\text { soil at an appropriate site on } \\
\text { the NTS. }\end{array}$ & $\begin{array}{l}\text { Limited worker risk associated } \\
\text { with excavation and disposal } \\
\text { of contaminated surface soils } \\
\text { through exposure to COCs, } \\
\text { operation of heavy equipment, } \\
\text { and installation and operation } \\
\text { of bioremediation system. } \\
\text { Appropriate level of PPE will } \\
\text { be used during excavation. } \\
\text { Limited environmental impact } \\
\text { during alternative } \\
\text { implementation because } \\
\text { removal areas are previously } \\
\text { disturbed and sparsely } \\
\text { vegetated. } \\
\text { Emissions from the } \\
\text { bioremediation system would } \\
\text { be limited through design. } \\
\text { Public protected by remote } \\
\text { location and NTS site access } \\
\text { controls. } \\
\text { Risks associated with } \\
\text { transportation minimized by } \\
\text { disposing of excavated } \\
\text { nonhazardous contaminated } \\
\text { soil at an appropriate site on } \\
\text { the NTS. }\end{array}$ & $\begin{array}{l}\text { - Limited worker risk associated } \\
\text { with excavation and disposal } \\
\text { of contaminated surface soils } \\
\text { through exposure to COCs, } \\
\text { operation of heavy equipment, } \\
\text { and installation and operation } \\
\text { of monitoring system. } \\
\text { Appropriate level of PPE will } \\
\text { be used during excavation. } \\
\text { Limited environmental impact } \\
\text { during alternative } \\
\text { implementation because } \\
\text { removal areas are previously } \\
\text { disturbed and sparsely } \\
\text { vegetated. } \\
\text { Public protected by remote } \\
\text { location and NTS site access } \\
\text { controls. } \\
\text { Risks associated with } \\
\text { transportation minimized by } \\
\text { disposing of excavated } \\
\text { nonhazardous contaminated } \\
\text { soil at an appropriate site on } \\
\text { the NTS. } \\
\text { The site will be monitored to } \\
\text { verify natural attenuation and } \\
\text { to determine rate. }\end{array}$ \\
\hline
\end{tabular}


Table 3-1

Detailed Evaluation of Alternatives

(Page 5 of 6 )

\begin{tabular}{|c|c|c|c|c|}
\hline Evaluation Criteria & $\begin{array}{c}\text { Alternative } 1 \\
\text { No Further Action }\end{array}$ & $\begin{array}{c}\text { Alternative } 2 \\
\text { Closure in Place with Partial } \\
\text { Excavation, Disposal, and } \\
\text { Administrative Controls }\end{array}$ & $\begin{array}{c}\text { Alternative } 3 \\
\text { Partial Excavation, Disposal, In } \\
\text { Situ Bioremediation, and } \\
\text { Administrative Controls }\end{array}$ & $\begin{array}{c}\text { Alternative 4 } \\
\text { Partial Excavation, Disposal, } \\
\text { Monitoring, and Administrative } \\
\text { Controls }\end{array}$ \\
\hline \multicolumn{5}{|c|}{ Closure Standards } \\
\hline $\begin{array}{l}\text { Reduction of Toxicity, } \\
\text { Mobility, and/or Volume }\end{array}$ & Not evaluated & $\begin{array}{l}\text { - Removal of contaminated } \\
\text { surface soil would result in } \\
\text { reduction of mobility and } \\
\text { volume at the site; proper } \\
\text { disposal would result in } \\
\text { reduced mobility at the } \\
\text { disposal location. } \\
\text { Removal of higher } \\
\text { concentrations of } \\
\text { contaminated soil will result in } \\
\text { lower toxicity. } \\
\text { Natural attenuation will likely } \\
\text { result in a decrease in toxicity, } \\
\text { mobility, and volume of the } \\
\text { remaining contaminated soil } \\
\text { with time. }\end{array}$ & $\begin{array}{l}\text { Removal of contaminated } \\
\text { surface soil would result in } \\
\text { reduction of mobility and } \\
\text { volume at the site; proper } \\
\text { disposal would result in } \\
\text { reduced mobility at the } \\
\text { disposal location. } \\
\text { Bioremediation will result in } \\
\text { reduction of toxicity, mobility, } \\
\text { and volume of the remaining } \\
\text { contaminated soil with time. }\end{array}$ & $\begin{array}{l}\text { Removal of contaminated } \\
\text { surface soil would result in } \\
\text { reduction of mobility and } \\
\text { volume at the site; proper } \\
\text { disposal would result in } \\
\text { reduced mobility at the } \\
\text { disposal location. } \\
\text { Natural attenuation will result } \\
\text { in reduction of toxicity, } \\
\text { mobility, and volume of the } \\
\text { remaining contaminated soil } \\
\text { with time. }\end{array}$ \\
\hline $\begin{array}{l}\text { Long-Term Reliability and } \\
\text { Effectiveness }\end{array}$ & Not evaluated & $\begin{array}{l}\text { - } \text { Controls inadvertent intrusion. } \\
\text { - } \text { requinistred. } \\
\text { Natural attenuation of COC controls } \\
\text { concentrations will result in } \\
\text { lower risk with time. }\end{array}$ & $\begin{array}{ll}\text { - } & \text { Controls inadvertent intrusion. } \\
\text { - } & \text { } \text { required. } \\
\text { - } & \text { Bioremediation of COC } \\
\text { concentrations, potentially to } \\
\text { PALs, will result in lower risk } \\
\text { with time. } \\
\text { - Maintenance and system } \\
\text { monitoring required. }\end{array}$ & $\begin{array}{l}\text { - } \\
\text { - } \\
\text { Administrative controls } \\
\text { required. } \\
\text { - Natural attenuation of COC } \\
\text { concentrations, potentially to } \\
\text { PALs, will result in lower risk } \\
\text { with time. } \\
\text { - Maintenance and system } \\
\text { monitoring required. }\end{array}$ \\
\hline
\end{tabular}


Table 3-1

Detailed Evaluation of Alternatives

(Page 6 of 6 )

\begin{tabular}{|c|c|c|c|c|}
\hline Evaluation Criteria & $\begin{array}{c}\text { Alternative } 1 \\
\text { No Further Action }\end{array}$ & $\begin{array}{c}\text { Alternative } 2 \\
\text { Closure in Place with Partial } \\
\text { Excavation, Disposal, and } \\
\text { Administrative Controls }\end{array}$ & $\begin{array}{c}\text { Alternative } 3 \\
\text { Partial Excavation, Disposal, In } \\
\text { Situ Bioremediation, and } \\
\text { Administrative Controls }\end{array}$ & $\begin{array}{c}\text { Alternative } 4 \\
\text { Partial Excavation, Disposal, } \\
\text { Monitoring, and Administrative } \\
\text { Controls }\end{array}$ \\
\hline \multicolumn{5}{|c|}{ Closure Standards } \\
\hline Feasibility & Not evaluated & $\begin{array}{l}\text { Easily implementable. } \\
\text { - No buildings, utilities, or other } \\
\text { interferences at the site. } \\
\text { Coordination of all entities is } \\
\text { necessary to ensure } \\
\text { compliance to prevent } \\
\text { intrusion into contaminated } \\
\text { soil zones. }\end{array}$ & $\begin{array}{l}\text { Implementable at the site; } \\
\text { however, testing would be } \\
\text { required to facilitate proper } \\
\text { design. } \\
\text { No buildings, utilities, or other } \\
\text { interferences at the site. } \\
\text { Coordination of all entities is } \\
\text { necessary to ensure } \\
\text { compliance to prevent } \\
\text { intrusion into contaminated } \\
\text { soil zones. }\end{array}$ & $\begin{array}{l}\text { Easily implementable. } \\
\text { - No buildings, utilities, or other } \\
\text { interferences at the site. } \\
\text { Coordination of all entities is } \\
\text { necessary to ensure } \\
\text { compliance to prevent } \\
\text { intrusion into contaminated } \\
\text { soil zones. }\end{array}$ \\
\hline Cost & $\$ 0$ & $\$ 216,011$ & $\$ 710,115$ & $\$ 180,195$ \\
\hline
\end{tabular}


Table 3-2

\section{Comparative Evaluation of Alternatives}

\begin{tabular}{|c|c|}
\hline Evaluation Criteria & Comparative Evaluation \\
\hline \multicolumn{2}{|r|}{ Closure Standards } \\
\hline $\begin{array}{l}\text { Protection of Human Health and the } \\
\text { Environment }\end{array}$ & $\begin{array}{l}\text { Alternatives } 2,3 \text {, and } 4 \text { meet corrective action objectives; Alternative } 1 \text { does not. No worker exposure to risks associated } \\
\text { with Alternative } 1 \text {. Highest risks are associated with Alternative } 2 \text { due to increase in exposures to higher concentrations of } \\
\text { COCs and greater volumes. Slightly lower risks are associated with Alternatives } 3 \text { and 4. NAC 445A.227 (2) (a-k) analysis } \\
\text { shows the contaminants are not impacting groundwater. }\end{array}$ \\
\hline $\begin{array}{l}\text { Compliance with Media Cleanup } \\
\text { Standards }\end{array}$ & $\begin{array}{l}\text { Alternative } 1 \text { does not comply with media cleanup standards. Alternatives } 2,3 \text {, and } 4 \text { meet media cleanup standards by } \\
\text { limiting exposure pathways through administrative controls and by removing contaminated surface and subsurface soils. } \\
\text { Bioremediation under Alternative } 3 \text { may reduce COC concentrations to PALs. Natural attenuation in Alternatives } 1,2 \text {, and } \\
4 \text { may result in reduced concentrations over time. }\end{array}$ \\
\hline Control the Source(s) of the Release & $\begin{array}{l}\text { The source(s) to the FTP are no longer viable. Under Alternatives } 2,3 \text {, and } 4 \text {, removal of contaminated surface soils will } \\
\text { prevent spread of contaminants to uncontaminated areas. }\end{array}$ \\
\hline $\begin{array}{l}\text { Comply with Applicable Federal, State, } \\
\text { and Local Standards for Waste } \\
\text { Management }\end{array}$ & All generated wastes will be handled in accordance with applicable regulations and requirements. \\
\hline \multicolumn{2}{|r|}{ Remedy Selection Decision Factors } \\
\hline $\begin{array}{l}\text { Short-Term Reliability and } \\
\text { Effectiveness }\end{array}$ & $\begin{array}{l}\text { Limited risks to workers are associated with Alternatives } 2,3 \text {, and } 4 . \text { The general public is not exposed to risk from the } \\
\text { COCs under any of the alternatives. }\end{array}$ \\
\hline $\begin{array}{l}\text { Reduction of Toxicity, Mobility, and/or } \\
\text { Volume }\end{array}$ & $\begin{array}{l}\text { Alternatives } 2,3 \text {, and } 4 \text { result in a reduction of mobility and volume through removal of the contaminated surface soils. For } \\
\text { Alternatives } 2 \text { and } 4 \text {, natural attenuation will likely reduce these characteristics for the remaining contaminated soils with } \\
\text { time. Alternative } 3 \text { reduces these characteristics through in situ bioremediation. }\end{array}$ \\
\hline $\begin{array}{l}\text { Long-Term Reliability and } \\
\text { Effectiveness }\end{array}$ & $\begin{array}{l}\text { Residual risk is low for both Alternatives } 2,3 \text {, and } 4 \text {. All three will require administrative measures to control intrusive } \\
\text { activities. Alternatives } 3 \text { and } 4 \text { require long-term monitoring and maintenance associated with the bioremediation or } \\
\text { monitoring system. }\end{array}$ \\
\hline Feasibility & $\begin{array}{l}\text { Alternatives } 2,3 \text {, and } 4 \text { are feasible; however, Alternative } 3 \text { requires testing prior to the bioremediation system design. All } \\
\text { three require heavy equipment, operating personnel, and disposal of wastes. Alternative } 2 \text { would be the easiest to } \\
\text { implement. }\end{array}$ \\
\hline Cost & $\begin{array}{l}\text { The cost for Alternative } 1 \text { is } \$ 0 \text {. The estimated cost for Alternative } 2 \text { is } \$ 216,011 \text { for partial excavation, disposal, and } \\
\text { administrative controls. Alternative } 3 \text { is estimated to cost } \$ 710,115 \text { for partial excavation, disposal, and in situ } \\
\text { bioremediation. Alternative } 4 \text { is estimated to cost } \$ 180,195 \text { for partial excavation, disposal, and natural attenuation } \\
\text { monitoring. }\end{array}$ \\
\hline
\end{tabular}




\subsection{Recommended Alternative}

Based on the results of the detailed and comparative analysis of the potential corrective action alternatives presented in this document, the preferred corrective action alternative selected for implementation at CAU 342 is Alternative 4, Partial Excavation, Disposal, Monitoring, and Administrative Controls. Alternative 4 was chosen because it:

- Minimizes health risks by preventing public access and controlling worker access to the contaminated soil through removal of surface soils and administrative controls.

- Complies with waste management standards because all waste will be managed in accordance with applicable federal, state, and local requirements.

- Minimizes long-term risks through removal of contaminated surface and limited subsurface soils, administrative controls, and natural attenuation of the COCs.

- Utilizes standard construction equipment for removal of contaminated soil for ease of implementation; administrative controls are easily implemented because the site has controlled access.

- Monitoring provides evidence of natural attenuation.

- Provides most cost-effective method for achieving protection and for meeting closure requirements.

The preferred corrective action alternative was evaluated on its technical merits, focusing on performance, reliability, feasibility, and safety. The alternative was judged to meet all requirements for the technical components evaluated. The alternative meets all applicable state and federal regulations for closure of the site and will eliminate potential future exposure pathways to the contaminated soil at the FTP.

This alternative will present minor risks to site workers during corrective action implementation. Therefore, appropriate health and safety procedures will be developed and implemented. 


\subsection{References}

CFR, see Code of Federal Regulations.

Code of Federal Regulations. 1998. Title 40 CFR Parts 260 - 282, "RCRA Regulations."

Washington, DC: U.S. Government Printing Office.

DOE/NV, see U.S. Department of Energy, Nevada Operations Office.

EPA, see U.S. Environmental Protection Agency.

FFACO, see Federal Facility Agreement and Consent Order.

Federal Facility Agreement and Consent Order. 1996 (as amended). Agreed to by the State of Nevada, the U.S. Department of Energy, and the U.S. Department of Defense.

Jacobson, S. Reynolds Electrical \& Engineering Company, Inc. 1991. Interview with R. Gudeman and H. Hill about site historical information. Las Vegas, NV.

La Camera, R.J., and C.L. Westenburg. 1994. Selected Ground-Water Data for Yucca Mountain Region, Southern Nevada and Eastern California, Through December 1992, USGS-OFR-94-54. Carson City, NV: U.S. Geological Survey.

Laczniak, R.J., J.C. Cole, D.A. Sawyer, and D.A. Trudeau. 1996. Summary of Hydrogeological Controls on Ground-Water Flow at the Nevada Test Site, Nye County, Nevada, U.S. Geological Survey Water-Resources Investigations Report 96-4109. Denver, CO: U.S. Geological Survey.

NAC, see Nevada Administrative Code.

NRC, see National Research Council.

NRS, see Nevada Revised Statutes.

National Research Council. 1993. In Situ Bioremediation: When Does It Work? Washington, DC: National Academy Press.

Nevada Administrative Code. 1996a. NAC 444, "Solid Waste Disposal." Carson City, NV.

Nevada Administrative Code. 1996b. NAC 445A, "Water Pollution Control." Carson City, NV.

Nevada Administrative Code. 1996c. NAC 459, "Disposal and Evaluation of Contaminated Soil." Carson City, NV. 
Nevada Revised Statutes. 1995. NRS 459.400-459.600, "Disposal of Hazardous Waste.” Carson City, NV.

REECo, see Reynolds Electrical \& Engineering Company, Inc.

Reynolds Electrical \& Engineering Company, Inc. 1991. Work Plan Area 23 Fire Training Area, Phase I Site Characterization. Prepared for the U.S. Department of Energy, Nevada Operations Office, Environmental Restoration Program. Las Vegas, NV.

Robie, L., S. Reiner, and G. Locke. 1995. Ground-water Data for the Nevada Test Site, 1992, and for Selected Other Areas in South-Central Nevada, 1952-92, USGS OFR-95-284. Denver, CO: U.S. Geological Survey.

Shacklette, H.T., and J.G. Boerngen. 1984. Element Concentrations in Soils and Other Surficial Materials of the Conterminous United States, U.S. Geological Survey Professional Paper 1270. Washington, DC: U.S. Government Printing Office.

U.S. Department of Energy, Nevada Operations Office. 1994. Project Management Plan, Rev. 0. Las Vegas, NV.

U.S. Department of Energy, Nevada Operations Office. 1996a. Final Environmental Impact Statement for the Nevada Test Site and Off-Site Locations in the State of Nevada, Vol. I, DOE/EIS 0243. Las Vegas, NV.

U.S. Department of Energy, Nevada Operations Office. 1996b. Industrial Sites Quality Assurance Project Plan, Nevada Test Site, Nevada, Rev. 1, DOE/NV--372. Las Vegas, NV.

U.S. Department of Energy, Nevada Operations Office. 1996c. Record of Decision: Environmental Impact Statement for the Nevada Test Site and Off-Site Locations in the State of Nevada, 6450-01-P. Washington, DC.

U.S. Department of Energy, Nevada Operations Office. 1998. Corrective Action Investigation Plan for Corrective Action Unit 342: Area 23 Mercury Fire Training Pit, Nevada Test Site, Nevada, Rev. 0, DOE/NV--498. Las Vegas, NV: IT Corporation.

U.S. Environmental Protection Agency, Office of Research and Development. 1991. Guidance on Resource Conservation and Recovery Act (RCRA) Corrective Action Decision Documents, EPA/540/G-91/011. Washington, DC.

U.S. Environmental Protection Agency, Office of Solid Waste and Emergency Response. 1994. Final RCRA Corrective Action Plan, EPA/520-R-94-004. Washington, DC. 
Winograd, I.J. and W. Thordarson. 1975. Hydrologic and Hydrochemical Framework, South-Central Great Basin, Nevada-California, with Special Reference to the Nevada Test Site, U.S. Geological Survey Professional Paper 712C. Washington, DC: U.S. Government Printing Office. 


\section{Appendix A}

Corrective Action Investigation Report for Corrective Action Unit 342: Area 23 Mercury Fire Training Pit, Nevada Test Site 


\section{A.1.0 Introduction}

The report contained in this appendix presents the investigation activities and analytical results from the corrective action investigation conducted at CAU 342, Area 23 Mercury Fire Training Pit, which consists of CAS 23-56-01. The corrective action investigation was conducted in accordance with the requirements set forth in the Corrective Action Investigation Plan for Corrective Action Unit 342: Area 23 Mercury Fire Training Pit Nevada Test Site, Nevada (DOE/NV, 1998) as developed under the FFACO (1996).

The FTP is located in Area 23 of the NTS on the west side of the Mercury Bypass Road and was used between approximately 1965 and 1990 to train fire-fighting personnel. Additional information relating to the site history, planning, and scope of the investigation is presented in the CAIP (DOE/NV, 1998) and is not repeated in this report.

\section{A.1.1 Project Objectives}

The primary objectives for this project were to:

- Identify the presence and nature of COPCs at the FTP.

- Determine the vertical and lateral extent of COPCs at the FTP.

- Provide sufficient information and data to develop and evaluate appropriate corrective action for the CAU.

A conceptual site model was developed to support the DQO process (DOE/NV, 1998) and used to guide the investigation. The soil at the FTP was investigated by various techniques. A passive soil gas survey was conducted to qualitatively assess the presence of VOCs and TPH (DOE/NV, 1998). Surface and near-surface samples were collected for laboratory analysis at both random and biased sampling points using direct push as well as manual collection techniques. Subsurface soil at the FTP was investigated by drilling and collecting soil samples for field screening and laboratory anaylsis. Drilling locations were selected based on the conceptual site model. 


\section{A.1.2 Report Content}

This corrective action investigation report is intended to provide information and data in sufficient detail to support the selection of a preferred corrective action alternative in the CADD. The contents of this report are as follows:

- Section A.1.0 describes the investigation background, objectives, and the report content.

- Section A.2.0 provides information regarding the field activities and sampling methods.

- Section A.3.0 summarizes the results of the laboratory analysis from the investigation.

- Section A.4.0 discusses the quality assurance (QA) and quality control (QC) procedures that were followed and the results of the QA and QC activities.

- Section A.5.0 summarizes the significant results pertaining to the Mercury FTP corrective action investigation.

- Section A.6.0 cites the references.

To make this report a concise summary, the complete field documentation and laboratory data, including Field Activity Daily Logs, Sample Collection Logs, Analysis Request/Chain of Custody Forms, soil sample descriptions, laboratory certificates of analyses, analytical results, and surveillance results are not contained in this report. These documents are retained in project files as both hard copy files and electronic media. 


\section{A.2.0 Field Investigation and Sampling Activities}

Field investigation and sampling activities were divided into three phases. The first phase involved the characterization and removal of the surface features from the FTP (September 1997 - April 1998). This included sampling and disposal of the telephone poles and liquid waste contained in the ASTs; and removal of the four ASTs, burn tank, two wooden sheds, and various debris (Figure A.2-1). The second phase was the passive soil gas survey (December 1997). Details of these two phases are discussed in the CAIP (DOE/NV, 1998) and are not documented in this report. The third phase was the investigation of possible soil contamination at the site (May - June 1998). This was divided into two tasks: collection of surface and near-surface soil samples and collection of subsurface soil samples. Prior to sample collection, a biological resources survey was conducted. No endangered species were identified in the investigation area.

The soil sampling phase of the investigation was managed in accordance with the requirements set forth in the CAIP (DOE/NV, 1998). The field activities were performed in accordance with an approved Site-Specific Health and Safety Plan (IT, 1998b). The samples were collected and documented by following approved sampling, field activity documentation, sample collection documentation, decontamination, chain of custody, shipping, and radiation screening protocols and procedures as indicated in the CAIP (DOE/NV, 1998). Quality control samples (e.g., field blanks, equipment rinsate blanks, trip blanks, and sample duplicates) were collected as required by the Industrial Sites Quality Assurance Project Plan (QAPP) (DOE/NV, 1996) and approved procedures. During field activities, waste minimization practices were followed according to approved procedures, including segregation of the waste by waste stream.

\section{A.2.1 Site Description and Conditions}

The site investigation included an area approximately 350 by $450 \mathrm{ft}$ (DOE/NV, 1998). There are no buildings or utilities within the CAS. Remaining surface features include the burn pit; small pieces of debris and scrap from historic site activities; and hydrocarbon and ash stains. The burn pit is approximately 65 by $27 \mathrm{ft}$ and is defined by a low berm 2 in. to $10 \mathrm{in}$. high (Figure A.2-1). 


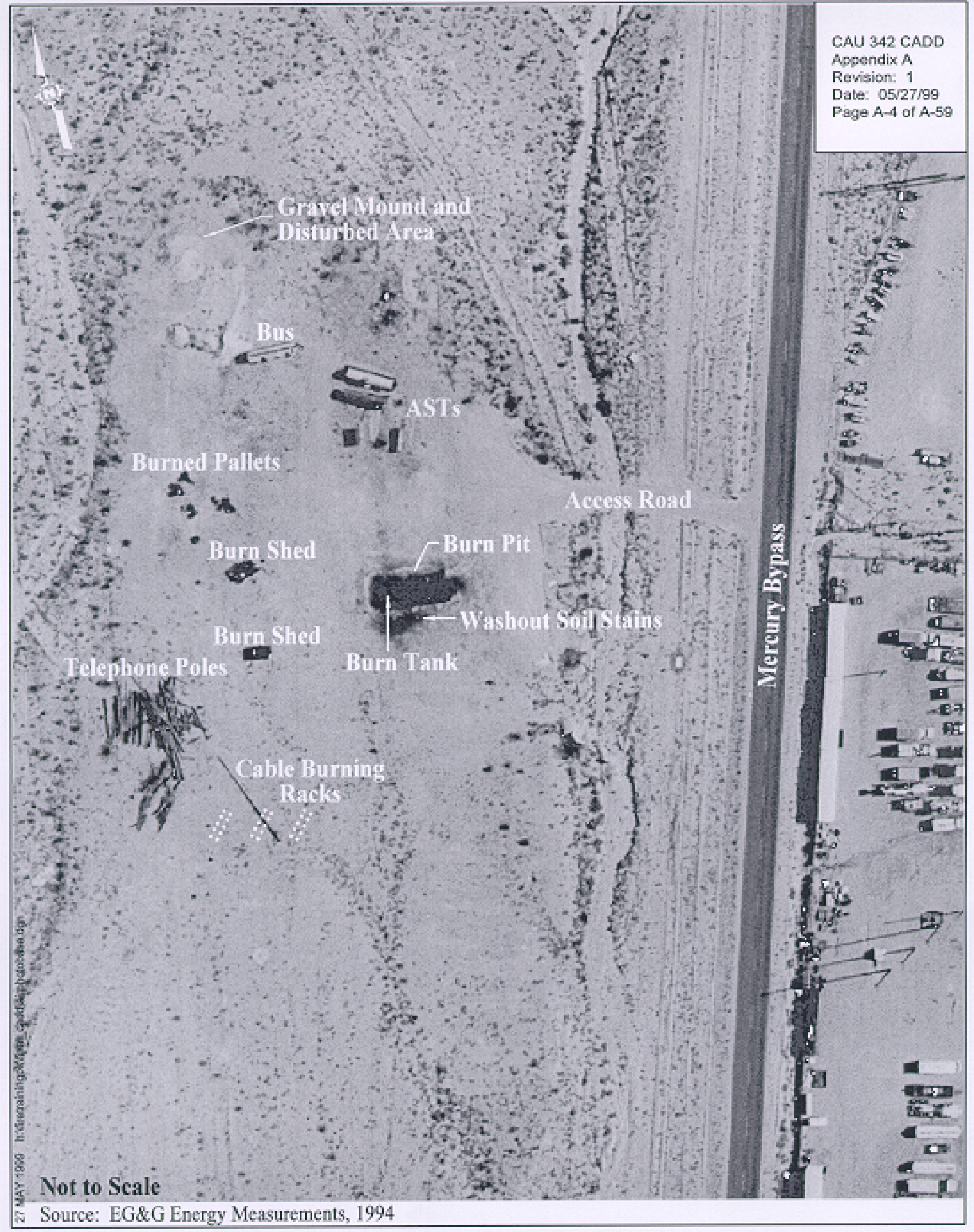

Figure A.2-1

Aerial View of the Mercury Fire Training Pit 


\section{A.2.2 Surface and Near-Surface Investigation}

Surface and near-surface samples were taken at 31 locations by a direct-push method (GeoProbe ${ }^{\circledR}$ ). Samples were collected at both random and biased locations. Biased samples were collected at each of the potentially contaminated site elements and noticeably stained soil locations. Random samples were collected from the approximate center of each grid cell (DOE/NV, 1998) which did not contain a biased sample location or a borehole.

Samples were collected by hand at three locations at the FTP. These samples were not discussed in the CAIP and were taken at the discretion of the Site Supervisor. Two of these sample locations were rock and soil piles located in the northwest corner of the site. There was no historical or site evidence that indicated contamination at these locations. The third sample location was an oil stain in the AST area.

The locations of surface and near-surface samples collected with the direct-push method and the surface samples collected by hand are presented on Figure A.2-2.

\section{A.2.2.1 Direct-Push Operation}

The direct-push equipment works by mechanically pushing and/or hammering a core barrel into the soil to the desired depth. The core barrel used at the FTP was $48 \mathrm{in.}$ long with an outside diameter of 2 in. The core barrel was lined with five 6-in. and one 4-in. long stainless steel sleeves. To obtain good soil recovery, the exact drive depth of the core barrel varied from 4.5 to $5.5 \mathrm{ft}$ bgs.

\section{A.2.2.2 Sample Collection}

Sample collection followed the procedures specified in the CAIP (DOE/NV, 1998). The core barrel was removed from the direct-push equipment and brought to the sample collection area. The core barrel was split open and screened for alpha and beta contamination. The breathing zone was also screened for VOCs. Sample sleeves were identified for collection. Teflon tape was placed over each end of the sleeve, the sleeve was capped, labeled, sealed with custody tape, and placed in an iced cooler with a trip blank. Each sample was made up of at least two sleeves. A third sleeve was submitted in some cases due to poor recovery in one of the sleeves designated for sample collection. Samples were collected at the locations identified in Table A.2-1. 


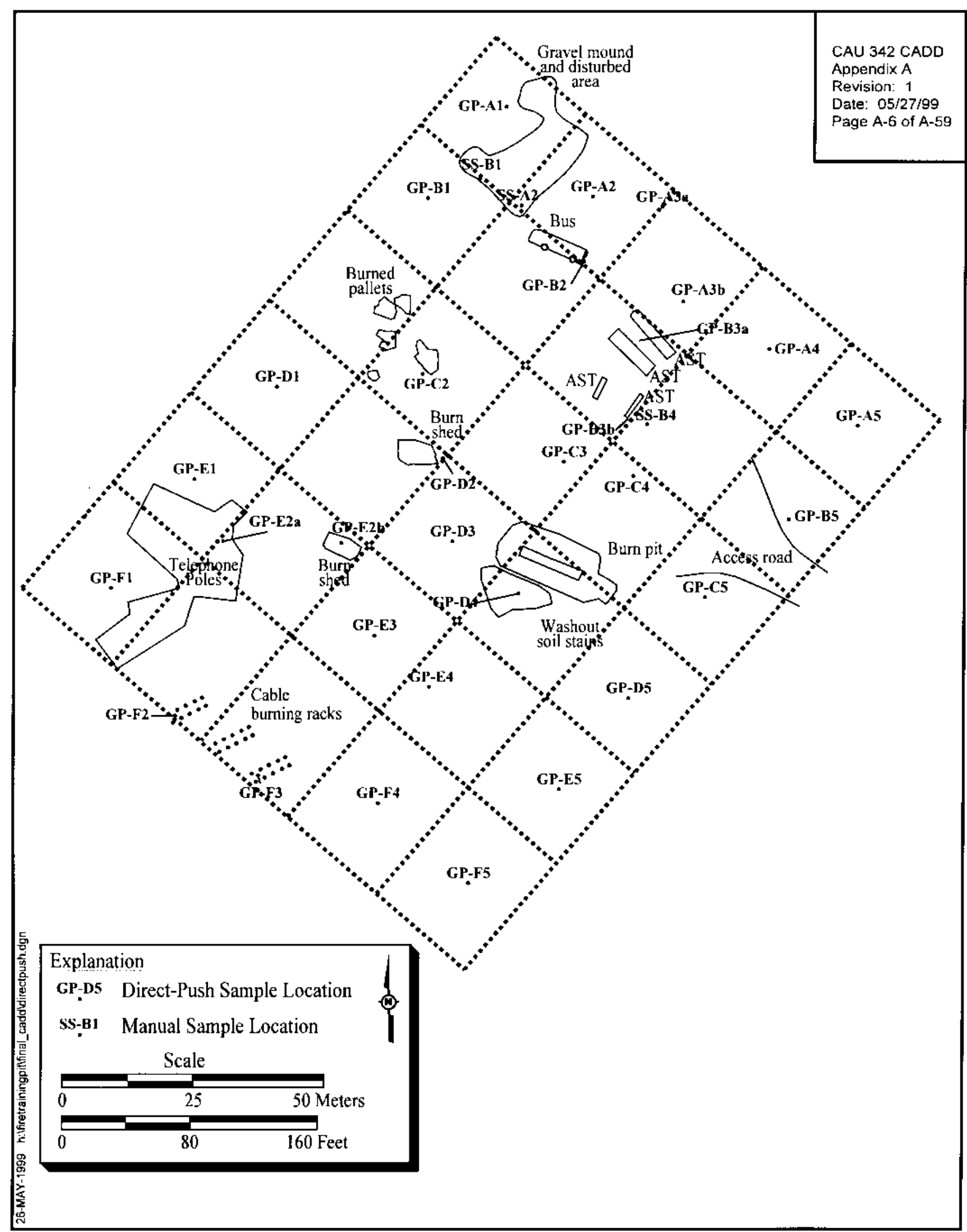

Figure A.2-2

Direct-Push and Manual Sample Collection Locations for Mercury Fire Training Pit 
All samples were analyzed for total VOCs, total SVOCs, total RCRA metals, TPH, and PCBs.

Samples collected from locations where physical evidence or site history indicated burning (e.g., cable racks, charcoal stains, and burn sheds) were analyzed for dioxins and furans. Surface samples were collected by hand for analyses using gamma spectroscopy at 18 of the 34 sample locations. Table A.2-1 summarize the analyses performed on each sample.

Table A.2-1

\section{Direct-Push and Surface Sample Locations and Analyses for Mercury Fire Training Pit}

(Page 1 of 4)

\begin{tabular}{|c|c|c|c|c|c|c|}
\hline $\begin{array}{l}\text { Sample } \\
\text { Location }^{\mathrm{a}}\end{array}$ & Site Element ${ }^{b}$ & $\begin{array}{l}\text { Sample } \\
\text { Number }\end{array}$ & $\begin{array}{c}\text { Start } \\
\text { Depth } \\
\text { (ft) }\end{array}$ & $\begin{array}{c}\text { End } \\
\text { Depth } \\
(\mathrm{ft})^{\mathrm{c}}\end{array}$ & $\begin{array}{c}\text { Sample } \\
\text { Type }\end{array}$ & $\begin{array}{l}\text { Analyses \& } \\
\text { Comments }^{d}\end{array}$ \\
\hline$\overline{\mathrm{NA}}$ & $\overline{\mathrm{NA}}$ & FTP00001 & $\overline{\mathrm{NA}}$ & $\overline{N A}$ & Trip Blank & VOCs only \\
\hline NA & NA & FTP00002 & NA & NA & Rinsate Blank & Dioxins/Furans \\
\hline NA & NA & FTP00003 & NA & NA & Trip Blank & VOCs only \\
\hline \multirow{2}{*}{ GP-F5 } & \multirow{2}{*}{ Random } & FTP00004 & 0 & 1 & \multirow{2}{*}{ Soil } & $--^{d}$ \\
\hline & & FTP00005 & 3 & 4 & & $--^{d}$ \\
\hline \multirow{2}{*}{ GP-F4 } & \multirow{2}{*}{$\begin{array}{l}\text { Random } \\
\left(\text { Drainage }^{\mathrm{e}}\right)\end{array}$} & FTP00006 & 0 & 1 & \multirow{2}{*}{ Soil } & $--^{d}$ \\
\hline & & FTP00007 & 3 & 4 & & $--^{d}$ \\
\hline \multirow{3}{*}{ GP-F3 } & \multirow{3}{*}{ Cable Racks } & FTP00008 & 0 & 1 & \multirow{3}{*}{ Soil } & Dioxins/Furans, Gamma \\
\hline & & FTP00009 & 3 & 4 & & $\begin{array}{c}\text { MS/MSD } \\
\text { Dioxins/Furans }\end{array}$ \\
\hline & & FTP00010 & 0 & 1 & & $\begin{array}{l}\text { Duplicate of FTP00008 } \\
\text { Dioxins/Furans, Gamma }\end{array}$ \\
\hline \multirow{2}{*}{ GP-F2 } & \multirow{2}{*}{ Cable Racks } & FTP00011 & 0 & 1 & \multirow{2}{*}{ Soil } & Dioxins/Furans \\
\hline & & FTP00012 & 3 & 4 & & Dioxins/Furans \\
\hline \multirow{2}{*}{ GP-F1 } & \multirow{2}{*}{ Random } & FTP00013 & 0 & 1 & \multirow{2}{*}{ Soil } & $--^{d}$ \\
\hline & & FTO00014 & 3 & 4 & & $--^{d}$ \\
\hline NA & NA & FTP00015 & NA & NA & Trip Blank & VOCs only \\
\hline NA & NA & FTP00016 & NA & NA & Field Blank & Dioxins/Furans \\
\hline NA & NA & FTP00017 & NA & NA & Trip Blank & VOCs only \\
\hline \multirow{2}{*}{ GP-E1 } & \multirow{2}{*}{ Random } & FTP00018 & 0 & 1 & \multirow{2}{*}{ Soil } & $--^{d}$ \\
\hline & & FTP00019 & 3 & 4 & & $--^{d}$ \\
\hline \multirow{2}{*}{ GP-E2a } & \multirow{2}{*}{ Telephone poles } & FTP00020 & 0 & 1 & \multirow{2}{*}{ Soil } & Gamma \\
\hline & & FTP00021 & 3 & 4 & & $--^{d}$ \\
\hline \multirow{2}{*}{ GP-E2b } & \multirow{2}{*}{ Burn shed } & FTP00022 & 0 & 1 & \multirow{2}{*}{ Soil } & Gamma \\
\hline & & FTP00023 & 3 & 4 & & $--^{d}$ \\
\hline
\end{tabular}


Table A.2-1

Direct-Push and Surface Sample Locations and Analyses for Mercury Fire Training Pit

(Page 2 of 4 )

\begin{tabular}{|c|c|c|c|c|c|c|}
\hline $\begin{array}{l}\text { Sample } \\
\text { Location }^{\mathrm{a}}\end{array}$ & Site Element ${ }^{b}$ & $\begin{array}{l}\text { Sample } \\
\text { Number }\end{array}$ & $\begin{array}{c}\text { Start } \\
\text { Depth } \\
\text { (ft) }\end{array}$ & $\begin{array}{c}\text { End } \\
\text { Depth } \\
(\mathrm{ft})^{\mathrm{c}}\end{array}$ & $\begin{array}{c}\text { Sample } \\
\text { Type }\end{array}$ & $\begin{array}{l}\text { Analyses \& } \\
\text { Comments }^{d}\end{array}$ \\
\hline \multirow{2}{*}{ GP-E3 } & \multirow{2}{*}{ Random } & FTP00024 & $\overline{0}$ & $\overline{11}$ & \multirow{2}{*}{ Soil } & $\overline{--d}$ \\
\hline & & FTP00025 & 3 & 4 & & $--^{d}$ \\
\hline \multirow{2}{*}{ GP-E4 } & \multirow{2}{*}{ Drainage $^{e}$} & FTP00026 & 0 & 1 & \multirow{2}{*}{ Soil } & $--^{d}$ \\
\hline & & FTP00027 & 3 & 4 & & $--^{d}$ \\
\hline \multirow{2}{*}{ GP-E5 } & \multirow{2}{*}{ Random } & FTP00028 & 0 & 1 & \multirow{2}{*}{ Soil } & Gamma \\
\hline & & FTP00029 & 3 & 4 & & $--^{d}$ \\
\hline NA & NA & FTP00030 & NA & NA & Rinsate blank & Dioxins/Furans \\
\hline NA & NA & FTP00031 & NA & NA & Trip blank & VOCs only \\
\hline \multirow{2}{*}{ GP-D5 } & \multirow{2}{*}{ Random } & FTP00032 & 0 & 1 & \multirow{2}{*}{ Soil } & $--^{d}$ \\
\hline & & FTP00033 & 3 & 4 & & $--^{d}$ \\
\hline \multirow{3}{*}{ GP-D4 } & \multirow{3}{*}{ Soil stains } & FTP00034 & 0 & 1 & \multirow{3}{*}{ Soil } & Dioxins/Furans, Gamma \\
\hline & & FTP00035 & 3 & 4 & & $\begin{array}{c}\text { MS/MSD } \\
\text { Dioxins/Furans }\end{array}$ \\
\hline & & FTP00036 & 0 & 1 & & $\begin{array}{l}\text { Duplicate of FTP00034 } \\
\text { Dioxins/Furans, Gamma }\end{array}$ \\
\hline \multirow{2}{*}{ GP-D3 } & \multirow{2}{*}{ Random } & FTP00037 & 0 & 1 & \multirow{2}{*}{ Soil } & $--^{d}$ \\
\hline & & FTP00038 & 3 & 4 & & $--^{d}$ \\
\hline \multirow{2}{*}{ GP-D2 } & \multirow{2}{*}{ Burn shed } & FTP00039 & 0 & 1 & \multirow{2}{*}{ Soil } & Gamma \\
\hline & & FTP00040 & 3 & 4 & & $--^{d}$ \\
\hline \multirow{2}{*}{ GP-D1 } & \multirow{2}{*}{ Random } & FTP00041 & 0 & 1 & \multirow{2}{*}{ Soil } & $--^{d}$ \\
\hline & & FTP00042 & 3 & 4 & & $--^{d}$ \\
\hline NA & NA & FTP00043 & NA & NA & Trip blank & VOCs only \\
\hline C1 & $N A^{g}$ & NA & NA & NA & NA & NA \\
\hline \multirow{2}{*}{ GP-C2 } & \multirow{2}{*}{ Burned pallets } & FTP00044 & 0 & 1 & \multirow{2}{*}{ Soil } & Gamma \\
\hline & & FTP00045 & 3 & 4 & & $--^{d}$ \\
\hline \multirow{2}{*}{ GP-C3 } & \multirow{2}{*}{ Soil stains } & FTP00046 & 0 & 1 & \multirow{2}{*}{ Soil } & $--^{d}$ \\
\hline & & FTP00047 & 3 & 4 & & $--^{d}$ \\
\hline $\mathrm{CD} C \mathrm{~A}$ & coilstoing & FTP00048 & 0 & 1 & Coil & Gamma \\
\hline GP-C4 & Soll stains & FTP00049 & 3 & 4 & soll & $--^{d}$ \\
\hline$C D C 5$ & Random & FTP00050 & 0 & 1 & Coil & $--^{d}$ \\
\hline GP-Co & haniaum & FTP00051 & 3 & 4 & soli & $--^{d}$ \\
\hline NA & NA & FTP00052 & NA & NA & Trip blank & VOCs only \\
\hline
\end{tabular}


Table A.2-1

Direct-Push and Surface Sample Locations and Analyses for Mercury Fire Training Pit

(Page 3 of 4 )

\begin{tabular}{|c|c|c|c|c|c|c|}
\hline $\begin{array}{l}\text { Sample } \\
\text { Location }^{\mathrm{a}}\end{array}$ & Site Element ${ }^{b}$ & $\begin{array}{l}\text { Sample } \\
\text { Number }\end{array}$ & $\begin{array}{c}\text { Start } \\
\text { Depth } \\
(\mathrm{ft})\end{array}$ & $\begin{array}{c}\text { End } \\
\text { Depth } \\
(\mathrm{ft})^{\mathrm{c}}\end{array}$ & $\begin{array}{c}\text { Sample } \\
\text { Type }\end{array}$ & $\begin{array}{l}\text { Analyses \& } \\
\text { Comments }^{d}\end{array}$ \\
\hline \multirow{2}{*}{ GP-B5 } & \multirow{2}{*}{$\begin{array}{c}\text { Random } \\
\text { (sample taken in } \\
\text { wash) }\end{array}$} & FTP00053 & 0 & 1 & \multirow{2}{*}{ Soil } & $--^{d}$ \\
\hline & & FTP00054 & 3 & 4 & & $--^{d}$ \\
\hline \multirow{2}{*}{ GP-B3b } & \multirow{2}{*}{$\begin{array}{l}\text { Soil stain } \\
\text { (small AST) }\end{array}$} & FTP00055 & 0 & 1 & \multirow{2}{*}{ Soil } & Gamma, TCLP Metals \\
\hline & & FTP00056 & 3 & 4 & & $--^{d}$ \\
\hline \multirow{3}{*}{ GP-B3a } & \multirow{3}{*}{$\begin{array}{l}\text { Soil stain } \\
\text { (large AST) }\end{array}$} & FTP00057 & 0 & 1 & \multirow{3}{*}{ Soil } & Gamma, TCLP Metals \\
\hline & & FTP00058 & 3 & 4 & & MS/MSD \\
\hline & & FTP00059 & 0 & 1 & & $\begin{array}{c}\text { Duplicate of FTP00057 } \\
\text { Gamma }\end{array}$ \\
\hline NA & NA & FTP00060 & NA & NA & Field blank & Dioxins/Furans \\
\hline NA & NA & FTP00061 & NA & NA & Trip blank & VOCs only \\
\hline \multirow{2}{*}{ GP-B2 } & \multirow{2}{*}{ Bus } & FTP00062 & 0 & 1 & \multirow{2}{*}{ Soil } & Gamma \\
\hline & & FTP00063 & 3 & 4 & & $--^{d}$ \\
\hline \multirow{2}{*}{ GP-B1 } & \multirow{2}{*}{ Random } & FTP00064 & 0 & 1 & \multirow{2}{*}{ Soil } & Dioxins/Furans, Gamma \\
\hline & & FTP00065 & 3 & 4 & & Dioxins/Furans \\
\hline NA & NA & FTP00066 & NA & NA & Trip blank & VOCs only \\
\hline \multirow{2}{*}{ GP-A1 } & \multirow{2}{*}{ Random } & FTP00067 & 0 & 1 & \multirow{2}{*}{ Soil } & Dioxins/Furans, Gamma \\
\hline & & FTP00068 & 3 & 4 & & Dioxins/Furans \\
\hline \multirow{2}{*}{ GP-A2 } & \multirow{2}{*}{ Random } & FTP00069 & 0 & 1 & \multirow{2}{*}{ Soil } & $--^{d}$ \\
\hline & & FTP00070 & 3 & 4 & & $--^{d}$ \\
\hline \multirow{2}{*}{ GP-A3a } & \multirow{2}{*}{$\begin{array}{l}\text { Soil stain } \\
\text { (burn area) }\end{array}$} & FTP00071 & 0 & 1 & \multirow{2}{*}{ Soil } & Dioxins/Furans, Gamma \\
\hline & & FTP00072 & 3 & 4 & & Dioxins/Furans \\
\hline \multirow{2}{*}{ GP-A3b } & \multirow{2}{*}{$\begin{array}{c}\text { Soil stain } \\
\text { (tire burn area) }\end{array}$} & FTP00073 & 0 & 1 & \multirow{2}{*}{ Soil } & Dioxins/Furans, Gamma \\
\hline & & FTP00074 & 3 & 4 & & Dioxins/Furans \\
\hline \multirow{2}{*}{ GP-A4 } & \multirow{2}{*}{ Random } & FTP00075 & 0 & 1 & \multirow{2}{*}{ Soil } & $--^{d}$ \\
\hline & & FTP00076 & 3 & 4 & & $--^{d}$ \\
\hline$A D \cap 5$ & Dondt & FTP00077 & 0 & 1 & Coil & $--^{d}$ \\
\hline GT-AS & nariucim & FTP00078 & 3 & 4 & soll & $--^{d}$ \\
\hline NA & NA & FTP00079 & NA & NA & Field blank & Dioxins/Furans \\
\hline NA & NA & FTP00080 & NA & NA & Trip blank & VOCs only \\
\hline NA & NA & FTP00081 & NA & NA & Rinsate blank & Dioxins/Furans \\
\hline NA & NA & FTP00082 & NA & NA & Trip blank & VOCs only \\
\hline SS-A2 & Soil pile & FTP00083 & 0.5 & 1.5 & Soil & $--^{d}$ \\
\hline
\end{tabular}


Table A.2-1

\section{Direct-Push and Surface Sample Locations and Analyses for Mercury Fire Training Pit}

(Page 4 of 4 )

\begin{tabular}{|c|c|c|c|c|c|c|}
\hline $\begin{array}{l}\text { Sample } \\
\text { Location }^{\mathrm{a}}\end{array}$ & Site Element ${ }^{\mathrm{b}}$ & $\begin{array}{l}\text { Sample } \\
\text { Number }\end{array}$ & $\begin{array}{c}\text { Start } \\
\text { Depth } \\
\text { (ft) }\end{array}$ & $\begin{array}{c}\text { End } \\
\text { Depth } \\
(\mathrm{ft})^{\mathrm{c}}\end{array}$ & $\begin{array}{c}\text { Sample } \\
\text { Type }\end{array}$ & $\begin{array}{l}\text { Analyses \& } \\
\text { Comments }^{d}\end{array}$ \\
\hline \multirow{2}{*}{ SS-B1 } & \multirow{2}{*}{ Soil pile } & $\overline{\text { FTP00084 }}$ & $\overline{0.5}$ & 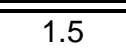 & \multirow{2}{*}{ Soil } & $\overline{--^{d}}$ \\
\hline & & FTP00085 & 0.5 & 1.5 & & Duplicate of FTP00084 \\
\hline SS-B4 & Soil stain & FTP00086 & 0 & 1 & Soil & $\begin{array}{c}\text { MS/MSD } \\
\text { TCLP Metals }\end{array}$ \\
\hline NA & NA & FTP00087 & NA & NA & Trip blank & VOCs only \\
\hline NA & NA & FTP00088 & NA & NA & Rinsate blank & Dioxins/Furans \\
\hline
\end{tabular}

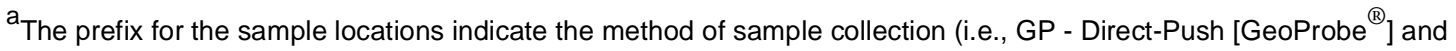
SS - Surface Sample collected by hand). See Figure A.2-2 for actual locations.

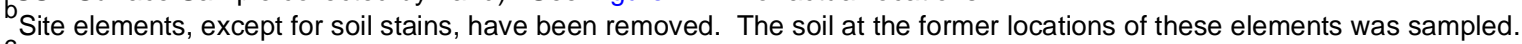

CThe start and end depths listed are approximate.

dAll samples were analyzed for the following unless otherwise noted: total VOCs; total SVOCs; total RCRA metals (arsenic, barium, cadmium, chromium, lead, mercury, selenium, silver) and zinc; TPH; and PCBs. Additional parameters are specified.

e This sample was collected in a natural drainage that originates from the "burn pit."

fSample "FTO00014" is correct. The "P" was replaced by the "O" due to a typo introduced into the database.

${ }^{9}$ Surface and near-surface samples were not collected using direct-push equipment because borehole B-2 was planned for this location (Table A.2-2).

NA $=$ Not applicable

MS/MSD = Matrix spike/matrix spike duplicate

\section{A.2.3 Subsurface Investigation}

Seventeen vertical boreholes were drilled at the FTP to investigate the subsurface soils. The rotary sonic ("sonic") drilling method was used to extract continuous cores from vertical borings. Recovery of continuous core allowed for detailed observations and sampling of the subsurface soil. Samples were collected from the cores at specified depth intervals for field-screening and laboratory analyses. Borings ranged from 15 to $70 \mathrm{ft}$ bgs. Field-screening for TPH (Hanby method) and VOCs (headspace screening) was used to guide the lateral and vertical extent of the investigation in the field. Sampling intervals and sample submission frequency were based on minimum requirements established during the DQO process, field-screening results, and the discretion of the Site Supervisor. Borehole locations are shown on Figure A.2-3. 


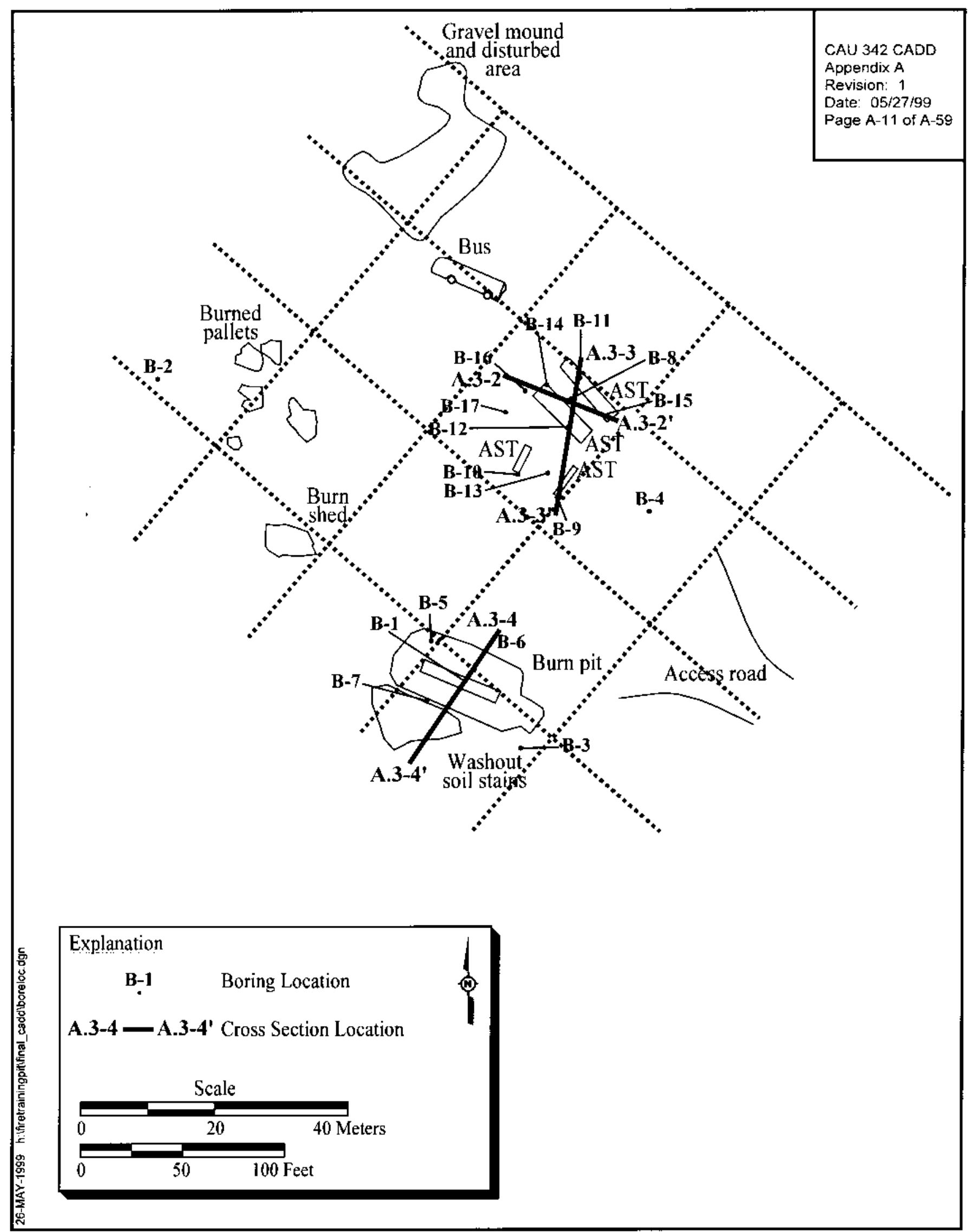

Figure A.2-3

Borehole Locations for Mercury Fire Training Pit 


\section{A.2.3.1 Drilling Operations}

The sonic drilling method uses vibration and rotation of the drill string to advance a core barrel and an outer casing. The casing is used to stabilize the hole and also minimizes potential cross contamination produced by soil from shallower depths falling down the hole (sloughing) as the core barrel is removed for core extrusion. After the bit at the end of the core barrel reaches the specified depth, the core barrel is withdrawn from the borehole and the contents are extruded into polyethylene (PE) bags. This investigation utilized 6-in. diameter core barrels with a 8-in. diameter casing. The casing was removed and the boreholes were filled with grout to complete each boring.

The sonic drilling method produced some heat from friction. On occasion, sample intervals were adjusted and samples were collected from a cooler section of the core. The temperature of the soil varied according to the difficulty of drilling (e.g., the soil was hotter when the ground was harder) due to the additional friction generated by driving the core barrel into harder and/or deeper conditions.

\section{A.2.3.2 Field Screening}

Field screening levels were established to guide the advancement of each borehole and selection of samples for laboratory analyses. The screening levels established were as follows:

- Total Petroleum Hydrocarbons - $100 \mathrm{mg} / \mathrm{kg}$ in accordance with the NDEP screening levels for TPH (NAC, 1996)

- Volatile Organic Compounds - 20 parts per million or 2.5 times background, whichever is higher (DOE/NV, 1998)

- Radioactivity - two times background levels (DOE/NV, 1998)

Field screening was preformed at 5-ft intervals to total depth or to $50 \mathrm{ft}$. Below $50 \mathrm{ft}$, field screening was performed at $10-\mathrm{ft}$ intervals. The field screening methods included:

- Total Petroleum Hydrocarbons - Hanby field testing kit manufactured by Hanby Environmental Laboratory Procedures, Inc.

- Volatile Organic Compounds - Headspace screening using a photoionization detector (PID) in conjunction with a warm water bath at a constant temperature.

- Radioactivity (alpha and beta) - Electra ${ }^{\mathrm{TM}}$ instrument 
At the discretion of the Site Supervisor, TPH field screening was not conducted at all specified locations to reduce use of TPH field screening reagents and minimize associated hazardous waste. The presence of odor and/or soil staining, VOC field screening results, and TPH field screening results in adjacent sample locations were used to select which locations would not be field screened. Supplementary field screening was conducted at the discretion of the Site Supervisor.

\section{A.2.3.3 Sample Collection}

Sample collection followed the procedures specified in the CAIP (DOE/NV, 1998) with the exception of the samples collected at varying depths due to heat in the soil core as explained in Section A.2.3.1. Soil cores were removed from the boreholes and transferred to the sampling area in approximately $2.5 \mathrm{ft}$ lengths contained in PE bags. The bags were split open and screened for alpha and beta emitting radionuclides. The soil and breathing zone were monitored for VOCs before sample collection using a PID. Samples were collected in appropriate containers with temporary sample labels. Samples to be analyzed for volatile parameters (total VOCs, TPH gasoline, TPH field screening, headspace field screening, and TCLP VOCs as appropriate) were collected directly from the soil cuttings immediately after required radiation field screening and VOC monitoring was performed. The remainder of the samples (TPH oil and diesel, SVOCs, total RCRA metals, PCBs, Dioxins and Furans, Gamma Spectroscopy, and TCLP metals as appropriate) were collected from soil representative of the sampling interval after homogenization in a stainless steel bowl. Samples were obtained at the locations specified in Table A.2-2.

After laboratory samples were identified, temporary labels were removed and the jars were labeled for shipment to the laboratory. Each sample container was then sealed with custody tape, wrapped in protective bubble wrap (if applicable), placed into a Ziploc ${ }^{\mathrm{TM}}$ bag, and placed in an iced cooler with a trip blank. Samples not submitted to the laboratory were containerized with other soil cores from the same boring upon removing or defacing temporary sample labels and removing sample jar lids.

Samples were analyzed for the parameters identified in Table A.2-2. 
Table A.2-2

Samples Collected During Subsurface Investigation at the Mercury Fire Training Pit (Page 1 of 3 )

\begin{tabular}{|c|c|c|c|c|c|}
\hline \begin{tabular}{|l|} 
Sample \\
Location
\end{tabular} & $\begin{array}{l}\text { Sample } \\
\text { Number }\end{array}$ & $\begin{array}{l}\text { Start Depth } \\
\text { (ft) }\end{array}$ & $\begin{array}{l}\text { End Depth } \\
\text { (ft) }\end{array}$ & Sample Type & $\begin{array}{l}\text { Analyses \& } \\
\text { Comments }^{\mathrm{a}}\end{array}$ \\
\hline $\mathrm{NA}$ & FTP00090 & $\mathrm{NA}$ & $\mathrm{NA}$ & Trip Blank & VOCs only \\
\hline NA & FTP00092 & NA & NA & Field Blank & Dioxins/Furans \\
\hline \multirow{7}{*}{$B-1$} & FTP00089 & 0 & 1 & Soil & $\begin{array}{l}\text { Gamma, TCLP Metals, TCLP } \\
\text { VOCs, Dioxins/Furans }\end{array}$ \\
\hline & FTP00091 & 4 & 5 & Soil & $\begin{array}{l}\text { TCLP Metals, TCLP VOCs, } \\
\text { Dioxins/Furans }\end{array}$ \\
\hline & FTP00094 & 19 & 20 & Soil & Dioxins/Furans, TCLP Metals \\
\hline & FTP00095 & 29 & 30 & Soil & Dioxins/Furans \\
\hline & FTP00093 & 30 & 31.5 & Soil & $\begin{array}{l}\text { Geotechnical \& Microbial } \\
\text { parameters only }\end{array}$ \\
\hline & FTP00096 & 34 & 35 & Soil & Dioxins/Furans \\
\hline & FTP00097 & 34 & 35 & Soil & $\begin{array}{c}\text { Dioxins/Furans } \\
\text { Duplicate of FTP00096 }\end{array}$ \\
\hline NA & FTP00098 & NA & NA & Trip Blank & VOCs only \\
\hline \multirow{3}{*}{ B-2 } & FTP00099 & 0 & 5 & Soil & MS/MSD \\
\hline & FTP00100 & 9 & 10 & Soil & $--^{a}$ \\
\hline & FTP00101 & 14 & 15 & Soil & $--^{a}$ \\
\hline \multirow{4}{*}{ B-3 } & FTP00103 & 4 & 5 & Soil & Dioxins/Furans \\
\hline & FTP00104 & 14 & 15 & Soil & Dioxins/Furans \\
\hline & FTP00105 & 19 & 20 & Soil & Dioxins/Furans \\
\hline & FTP00102 & 20 & 21.5 & Soil & $\begin{array}{l}\text { Geotechnical \& Microbial } \\
\text { parameters only }\end{array}$ \\
\hline NA & FTP00106 & NA & NA & Trip Blank & VOCS only \\
\hline \multirow{3}{*}{ B-4 } & FTP00107 & 4 & 5 & Soil & TCLP VOCs \\
\hline & FTP00108 & 14 & 15 & Soil & $--^{a}$ \\
\hline & FTP00109 & 19 & 20 & Soil & $--^{a}$ \\
\hline \multirow{6}{*}{ B-5 } & FTP00111 & 4 & 5 & Soil & Dioxins/Furans, TCLP Metals \\
\hline & FTP00110 & 5 & 6.5 & Soil & $\begin{array}{l}\text { Geotechnical \& Microbial } \\
\text { parameters only }\end{array}$ \\
\hline & FTP00112 & 9 & 10 & Soil & Dioxins/Furans, TCLP Metals \\
\hline & B5-14-15M & 16 & 17.5 & Soil & Microbial parameters only \\
\hline & FTP00113 & 24 & 25 & Soil & Dioxins/Furans \\
\hline & FTP00114 & 29 & 30 & Soil & Dioxins/Furans \\
\hline NA & FTP00115 & NA & NA & Trip Blank & VOCs only \\
\hline NA & FTP00116 & NA & NA & Field Blank & Dioxins/Furans \\
\hline NA & FTP00117 & NA & NA & Trip Blank & VOCs only \\
\hline NA & FTP00119 & NA & NA & Rinsate Blank & Dioxins/Furans \\
\hline
\end{tabular}


Table A.2-2

Samples Collected During Subsurface Investigation at the Mercury Fire Training Pit (Page 2 of 3 )

\begin{tabular}{|c|c|c|c|c|c|}
\hline \begin{tabular}{|c|} 
Sample \\
Location
\end{tabular} & $\begin{array}{l}\text { Sample } \\
\text { Number }\end{array}$ & $\begin{array}{l}\text { Start Depth } \\
\text { (ft) }\end{array}$ & $\begin{array}{l}\text { End Depth } \\
\text { (ft) }\end{array}$ & Sample Type & $\begin{array}{l}\text { Analyses \& } \\
\text { Comments }^{\mathrm{a}}\end{array}$ \\
\hline \multirow{4}{*}{ B-6 } & FTP00120 & $\overline{4}$ & $\overline{5}$ & $\overline{\text { Soil }}$ & Dioxins/Furans \\
\hline & FTP00121 & 14 & 15 & Soil & Dioxins/Furans \\
\hline & FTP00118 & 16 & 17.5 & Soil & Geotechnical parameters only \\
\hline & FTP00122 & 19 & 20 & Soil & Dioxins/Furans \\
\hline \multirow{3}{*}{ B-7 } & FTP00123 & 4 & 5 & Soil & Dioxins/Furans \\
\hline & FTP00124 & 14 & 15 & Soil & Dioxins/Furans \\
\hline & FTP00125 & 19 & 20 & Soil & Dioxins/Furans \\
\hline NA & FTP00126 & NA & NA & Trip Blank & VOCs only \\
\hline \multirow{6}{*}{ B-8 } & FTP00128 & 9 & 10 & Soil & TCLP Metals \\
\hline & B8-14-15M & 14 & 15 & Soil & Microbial parameters only \\
\hline & FTP00129 & 34 & 35 & Soil & $--^{a}$ \\
\hline & FTP00130 & 49 & 50 & Soil & $--^{a}$ \\
\hline & FTP00131 & 59 & 60 & Soil & $--^{a}$ \\
\hline & FTP00132 & 69 & 70 & Soil & $--^{a}$ \\
\hline NA & FTP00127 & NA & NA & Trip Blank & VOCs only \\
\hline \multirow{3}{*}{ B-9 } & FTP00133 & 9 & 10 & Soil & TCLP Metals \\
\hline & FTP00134 & 19 & 20 & Soil & $--^{a}$ \\
\hline & FTP00135 & 24 & 25 & Soil & $--^{a}$ \\
\hline \multirow{5}{*}{$B-10$} & FTP00136 & 14 & 15 & Soil & $--^{a}$ \\
\hline & FTP00137 & 29 & 30 & Soil & MS/MSD \\
\hline & FTP00138 & 34 & 35 & Soil & $--^{a}$ \\
\hline & FTP00139 & 34 & 35 & Soil & Duplicate of FTP00138 \\
\hline & FTP00140 & 39 & 40 & Soil & $--^{a}$ \\
\hline NA & FTP00141 & NA & NA & Trip Blank & VOCs only \\
\hline NA & FTP00142 & NA & NA & Rinsate Blank & Dioxins/Furans \\
\hline NA & FTP00143 & NA & NA & Trip Blank & VOCs only \\
\hline NA & FTP00144 & NA & NA & Field Blank & Dioxins/Furans \\
\hline \multirow{3}{*}{ B-11 } & FTP00145 & 19 & 20 & Soil & $--^{a}$ \\
\hline & FTP00146 & 39 & 40 & Soil & $--^{a}$ \\
\hline & FTP00147 & 44 & 45 & Soil & $--^{a}$ \\
\hline \multirow{4}{*}{ B-12 } & FTP00149 & 19 & 20 & Soil & $--^{a}$ \\
\hline & FTP00148 & 35 & 36.5 & Soil & $\begin{array}{l}\text { Geotechnical \& Microbial } \\
\text { parameters only }\end{array}$ \\
\hline & FTP00150 & 49 & 50 & Soil & $--^{a}$ \\
\hline & FTP00151 & 69 & 70 & Soil & $--^{a}$ \\
\hline NA & FTP00152 & NA & NA & Trip Blank & VOCs only \\
\hline B-13 & FTP00153 & 39 & 40 & Soil & $--^{a}$ \\
\hline
\end{tabular}


Table A.2-2

Samples Collected During Subsurface Investigation at the Mercury Fire Training Pit (Page 3 of 3 )

\begin{tabular}{|c|c|c|c|c|c|}
\hline $\begin{array}{l}\text { Sample } \\
\text { Location }\end{array}$ & $\begin{array}{l}\text { Sample } \\
\text { Number }\end{array}$ & $\begin{array}{l}\text { Start Depth } \\
\text { (ft) }\end{array}$ & $\begin{array}{l}\text { End Depth } \\
\text { (ft) }\end{array}$ & Sample Type & $\begin{array}{l}\text { Analyses \& } \\
\text { Comments }^{\mathrm{a}}\end{array}$ \\
\hline \multirow{4}{*}{ B-14 } & FTP00154 & 24 & 25 & Soil & TCLP Metals \\
\hline & B14-29-30M & 29 & 30 & Soil & Microbial parameters only \\
\hline & FTP00155 & 39 & 40 & Soil & $--^{a}$ \\
\hline & FTP00156 & 68 & 69 & Soil & $--^{a}$ \\
\hline B-15 & FTP00157 & 26 & 27 & Soil & $--^{a}$ \\
\hline \multirow{5}{*}{ B-16 } & FTP00160 & 18.5 & 19 & Soil & $--^{a}$ \\
\hline & FTP00161 & 33 & 34 & Soil & $--^{a}$ \\
\hline & FTP00158 & 40 & 41.5 & Soil & Geotechnical parameters only \\
\hline & FTP00159 & 50 & 51.5 & Soil & $\begin{array}{l}\text { Geotechnical \& Microbial } \\
\text { parameters only }\end{array}$ \\
\hline & FTP00162 & 54 & 55 & Soil & $--^{a}$ \\
\hline \multirow{2}{*}{ B-17 } & FTP00163 & 29 & 30 & Soil & $--^{a}$ \\
\hline & FTP00164 & 51.5 & 52.5 & Soil & $--^{a}$ \\
\hline
\end{tabular}

aAll soil samples were analyzed for the following unless otherwise noted: total VOCs; total SVOCs; total RCRA metals (arsenic, barium, cadmium, chromium, lead, mercury, selenium, silver); TPH; and PCBs. Additional parameters are specified.

NA = Not applicable

MS/MSD = Matrix spike/matrix spike duplicate

\section{A.2.4 Waste Management}

Investigation derived waste was segregated into the following waste streams:

- Personal protective equipment and disposable sampling equipment

- Decontamination rinsate

- Soil and debris (plastic sheeting, sample jars, PE bags) incidental to sample collection

- Plastic used under drill rig and to line decontamination sumps

- Personal protective equipment, sampling debris, spent solvent, soil, and rinsate generated from the use of the Hanby field screening kit

Potentially hazardous waste generated during the investigation was placed in 55-gallon drums, labeled as "Hazardous Waste - Pending Analysis," and placed in a 90-day Hazardous Waste 
Accumulation Area. The amount, type, and source of waste placed into each drum was recorded in a waste management log.

A total of 8955 -gallon drums of waste were generated during the investigation. The waste in 13 drums was characterized as hazardous and turned over to the NTS prime contractor for shipment to an off-site treatment, storage, and disposal facility. Waste was characterized as hazardous due to elevated lead (Sample FTP00011) or cadmium (Samples FTP00089 and FTP00091) concentrations, or because it was associated with TPH field testing kits which utilize carbon tetrachloride as a solvent. The remaining waste was characterized as sanitary and turned over to the NTS prime contractor for disposal in an on-site sanitary waste disposal unit.

\section{A.2.5 Geology}

The FTP is located on an alluvial slope. The surface slopes toward the southwest from Red Mountain (carbonate rock) toward Mercury Valley and consists of detrital material composed of silty sands, gravels, and cobbles. Localized caliche is present to 55-ft bgs. Some cobbles up to 6-in. in diameter were noted.

Field descriptions performed by the field geologist for each boring were recorded on a Visual Classification of Soil Log, and indicate that the stratigraphy is dominated by moderate to poorly sorted gravelly sand, with occasional silty gravelly sand. Small lenses of silt and clay are also present, along with isolated caliche layers. The caliche was noted as follows:

- B-10 Approximately 3-in. thick caliche layer noted at 11 to $12 \mathrm{ft}$ bgs and 24 to $25 \mathrm{ft}$ bgs.

- B-12 Caliche layers noted at 12 to $13 \mathrm{ft}$ bgs, 42 to $42.5 \mathrm{ft}$ bgs, $53 \mathrm{ft}$ bgs, and 57.5 to $60 \mathrm{ft}$ bgs.

- B-13 Approximately 3-in. thick caliche layer noted at $25 \mathrm{ft}$ bgs.

- B-17 Approximately 2-in. thick caliche layer noted at $51.5 \mathrm{ft}$ bgs.

The caliche layers in boreholes B-10, B-12, B-13, and B-17 correspond with either decreased or below detection level TPH field screening readings, indicating that the caliche is acting as an impediment to contaminant migration. See Appendix B for the complete soil boring logs. 


\section{A.2.6 Hydrology}

Average annual precipitation for valleys in the South-Central Great Basin range from 3 to 6 in.

(Winograd and Thordarson, 1975). Precipitation events are ephemeral and highly variable in the arid environment. Ponding of precipitation within the burn pit is possible. The burn pit is surrounded by a low berm ranging from 2-in. to 10-in. high, and enclosing a 2,400 $\mathrm{ft}^{2}$ area. Standing water is unlikely for the remainder of the FTP because the site is well drained by adjacent stream drainages on the east and west. The elevation at the site is approximately 3,740 ft above sea level (USGS; 1983a and b). At Mercury Valley the depth to groundwater ranges from 800 to 1,100 $\mathrm{ft}$ bgs (Winograd and Thordarson, 1975; Robie et al., 1995). 


\section{A.3.0 Investigation Results}

The analytical results of samples collected from the FTP have been compiled and evaluated to determine the presence and/or extent of contamination. The analytical results are summarized in the following subsections. The complete laboratory result data packages are in the project files.

During the investigation activities, 167 samples (133 soil and 34 liquid samples) were collected and submitted for laboratory analysis. Eight soil samples were submitted for bioassessment analysis. Seven were submitted for geotechnical analysis. Six field duplicates were collected and submitted for laboratory analysis. Nine samples were resubmitted for additional analysis (TCLP metals) based on review of initial results. The recollection of one sample for PCB analysis was required after initial results were rejected during validation.

The analytical parameters and laboratory analytical methods requested for this investigation are presented in Table A.3-1. The analytical parameters were selected through the application of site knowledge using the EPA's Guidance for the Data Quality Objectives Process (EPA, 1994a). Preliminary action levels for off-site laboratory analytical methods were determined during the DQO process and are based on NAC 445A.2272 (NAC, 1996) and the EPA Region IX Preliminary Remediation Goals (PRGs) (EPA, 1996a) for chemical parameters under the industrial scenario. The results of the DQO process are documented in the CAIP (DOE/NV, 1998). Sampling activities were designed to detect contaminants of potential concern and conducted to either prove or disprove the assumptions made in the DQO process.

Samples collected from the FTP were analyzed by Quanterra Environmental Services in Earth City, Missouri. Additional analyses (TCLP and totals metals) for several samples were performed at DataChem Laboratories Inc., in Salt Lake City, Utah. Geotechnical samples were analyzed by Converse Consulting in Las Vegas, Nevada. The bioassessment was performed by IT Corporation in Knoxville, Tennessee. Third-party data validation was performed by Lockheed-Martin Environmental Services in Las Vegas, Nevada. 


\section{Table A.3-1 \\ Laboratory Analytical Methods Used for the Mercury Fire Training Pit Investigation Soil Samples}

\begin{tabular}{|c|c|}
\hline Chemical and Radiological Parameter & Analytical Method \\
\hline Total petroleum hydrocarbons (diesel/oil \& gasoline) & EPA 8015B (modified) ${ }^{a}$ \\
\hline $\begin{array}{l}\text { Total RCRA metals (arsenic, barium, cadmium, chromium, lead, } \\
\text { selenium, silver, and mercury) and zinc }\end{array}$ & EPA $6010 \mathrm{~B} / 7470 \mathrm{~A} / 7471 \mathrm{~A}^{\mathrm{a}}$ \\
\hline \multirow{2}{*}{ TCLP metals } & EPA1311/7470A/7471A ${ }^{a}$ \\
\hline & EPA $1311 / 6010 B^{a}$ \\
\hline Total volatile organic compounds & EPA $8260 B^{a}$ \\
\hline TCLP volatile organic compounds & EPA $1311 / 8260 B^{a}$ \\
\hline Total semivolatile organic compounds & EPA $8270 C^{a}$ \\
\hline Dioxins and Furans & EPA $8280^{a}$ \\
\hline Total polychlorinated biphenyls & EPA $8082^{a}$ \\
\hline Gamma-Emitting Radionuclides & HASL $300,4.5 .2 .3^{b}$ \\
\hline Geotechnical and Hydraulic Parameters & Method \\
\hline Initial moisture content & ASTM D 2216 \\
\hline Dry bulk density & EM-1110-2-1906 \\
\hline Calculated porosity & EM-1110-2-1906 ${ }^{d}$ \\
\hline Saturated hydraulic conductivity & ASTM D 5084 \\
\hline Unsaturated hydraulic conductivity & Not analyzed \\
\hline Particle-size distribution & ASTM D $422^{\mathrm{C}}$ \\
\hline Water-release (moisture retention) curve & ASTM D 3152 \\
\hline Bioassessment Parameters & Method \\
\hline Soil $\mathrm{pH}$ and moisture & \multirow{4}{*}{ Laboratory specific $^{f}$} \\
\hline Background nutrient concentrations & \\
\hline Microbial enumerations & \\
\hline Microbial stimulation test & \\
\hline
\end{tabular}

${ }^{a}$ EPA Test Methods for Evaluating Solid Waste, 3rd Edition, Parts 1-4, SW-846 (EPA, 1996b)

${ }^{b}$ Environmental Measurements Laboratory Procedures Manual, HASL-300, U. S. Department of Energy (DOE, 1992)

${ }^{c}$ Annual Book of American Society for Testing and Materials (ASTM) Standards, Section 4, "Construction," Volume 04.08, "Soil and Rock (1)," and Volume 04.09, "Soil and Rock (11)," 1996

'U.S. Army Corps of Engineers (USACE), Engineer Manual (EM) 1110-2-1906, "Laboratory Soils Testing," Appendix II, 1970

${ }^{\mathrm{e}}$ Test requested but not performed by laboratory due to soil characteristics

${ }^{\mathrm{f}}$ Techniques described in Bioassessment Report Nevada Test Site CAU 342; Area 23 Mercury Fire Training Pit,

IT Corporation, 1998a 


\section{A.3.1 Total Petroleum Hydrocarbon Analytical Results}

The TPH compounds detected above minimum reporting limits (DOE/NV, 1998) are provided in Table A.3-2. Concentrations exceeding the action level of $100 \mathrm{mg} / \mathrm{kg}$ are shaded. Diesel, waste oil, gasoline, and unknown hydrocarbons were detected in the soil samples. The unknown hydrocarbons were detected in the diesel and waste oil analyses of the soil samples but did not match either the diesel or the waste oil peak patterns. These unknown hydrocarbons could be attributed to aromatic, halogenated and nonhalogenated volatile, and semivolatile compounds, and/or other petroleum hydrocarbons (i.e., nondiesel, nongasoline, and nonwaste oil) present in the samples.

Table A.3-2

Soil Sample Results for Total Petroleum Hydrocarbons Detected Above Minimum Reporting Limits, Mercury Fire Training Pit, Nevada Test Site (Page 1 of 2)

\begin{tabular}{|c|c|c|c|c|c|c|c|}
\hline \multirow{2}{*}{$\begin{array}{l}\text { Sample } \\
\text { Location }\end{array}$} & \multirow{2}{*}{$\begin{array}{l}\text { Sample } \\
\text { Number }\end{array}$} & \multirow{2}{*}{$\begin{array}{c}\text { Start Depth } \\
\text { (ft) }\end{array}$} & \multirow{2}{*}{$\begin{array}{l}\text { End Depth } \\
\text { (ft) }\end{array}$} & \multicolumn{4}{|c|}{ Contaminant of Potential Concern $(\mathrm{mg} / \mathrm{kg})$} \\
\hline & & & & Diesel & Waste Oil & Gasoline & $\begin{array}{l}\text { Unknown } \\
\text { Hydrocarbon }\end{array}$ \\
\hline GP-E2a & FTP00020 & 0 & 1 & $\begin{array}{l}- \\
-\end{array}$ & -- & -- & 440 \\
\hline GP-E2a & FTP00021 & 3 & 4 & -- & -- & -- & 420 \\
\hline GP-E2b & FTP00022 & 0 & 1 & -- & -- & -- & 130 \\
\hline GP-E3 & FTP00024 & 0 & 1 & -- & -- & -- & 45 \\
\hline GP-E3 & FTP00025 & 3 & 4 & -- & -- & -- & 100 \\
\hline GP-E4 & FTP00026 & 0 & 1 & -- & -- & -- & 230 \\
\hline GP-E4 & FTP00027 & 3 & 4 & -- & -- & -- & 420 \\
\hline GP-E5 & FTP00028 & 0 & 1 & -- & -- & -- & 180 \\
\hline GP-E5 & FTP00029 & 3 & 4 & -- & -- & -- & 370 \\
\hline GP-D4 & FTP00034 & 0 & 1 & -- & -- & -- & 210 \\
\hline GP-D4 & FTP00035 & 3 & 4 & -- & -- & -- & 590 \\
\hline GP-D4 & FTP00036 & 0 & 1 & -- & -- & -- & 760 \\
\hline GP-C4 & FTP00048 & 0 & 1 & 250 & -- & -- & -- \\
\hline GP-C4 & FTP00049 & 3 & 4 & -- & -- & -- & 3,000 \\
\hline GP-B3b & FTP00055 & 0 & 1 & -- & -- & -- & 4,000 \\
\hline GP-B3b & FTP00056 & 3 & 4 & 2,800 & -- & -- & -- \\
\hline GP-B3a & FTP00057 & 0 & 1 & -- & -- & -- & 410 \\
\hline GP-B3a & FTP00058 & 3 & 4 & 2,500 & -- & -- & -- \\
\hline GP-B3a & FTP00059 & 0 & 1 & -- & -- & -- & 130 \\
\hline GP-B2 & FTP00062 & 0 & 1 & -- & 1,400 & -- & -- \\
\hline SS-B4 & FTP00086 & 0 & 1 & -- & -- & -- & 4,000 \\
\hline B-1 & FTP00089 & 0 & 1 & $4,100(\mathrm{~J})$ & -- & $4.8(\mathrm{Y})$ & -- \\
\hline B-1 & FTP00091 & 4 & 5 & $3,400(\mathrm{~J})$ & -- & $5.2(\mathrm{Y})$ & -- \\
\hline B-1 & FTP00094 & 19 & 20 & $10,000(\mathrm{~J})$ & -- & $1.7(\mathrm{Y})$ & -- \\
\hline B-3 & FTP00103 & 4 & 5 & -- & -- & -- & 37 \\
\hline
\end{tabular}


Table A.3-2

Soil Sample Results for Total Petroleum Hydrocarbons Detected Above Minimum Reporting Limits, Mercury Fire Training Pit, Nevada Test Site

(Page 2 of 2)

\begin{tabular}{|c|c|c|c|c|c|c|c|}
\hline \multirow{2}{*}{$\begin{array}{l}\text { Sample } \\
\text { Location }\end{array}$} & \multirow{2}{*}{$\begin{array}{l}\text { Sample } \\
\text { Number }\end{array}$} & \multirow{2}{*}{$\begin{array}{c}\text { Start Depth } \\
\text { (ft) }\end{array}$} & \multirow{2}{*}{$\begin{array}{l}\text { End Depth } \\
\text { (ft) }\end{array}$} & \multicolumn{4}{|c|}{ Contaminant of Potential Concern $(\mathrm{mg} / \mathrm{kg})$} \\
\hline & & & & Diesel & Waste Oil & Gasoline & $\begin{array}{c}\text { Unknown } \\
\text { Hydrocarbon }\end{array}$ \\
\hline$\overline{\mathrm{B}-3}$ & $\overline{\text { FTP00104 }}$ & $\overline{14}$ & $\overline{15}$ & $\overline{---}$ & $\overline{---}$ & $\overline{---}$ & $\overline{\overline{46}}$ \\
\hline B-4 & FTP00107 & 4 & 5 & -- & -- & -- & 27 \\
\hline B-4 & FTP00108 & 14 & 15 & -- & 230 & -- & -- \\
\hline B-4 & FTP00109 & 19 & 20 & 140 & -- & -- & -- \\
\hline B-5 & FTP00111 & 4 & 5 & -- & -- & -- & 3,300 \\
\hline B-5 & FTP00112 & 9 & 10 & -- & -- & -- & 10,000 \\
\hline B-7 & FTP00124 & 14 & 15 & -- & -- & -- & 61 \\
\hline B-8 & FTP00128 & 9 & 10 & $16,000(\mathrm{~J})$ & -- & $530(Y)$ & -- \\
\hline B-8 & FTP00129 & 34 & 35 & -- & -- & $1.6(\mathrm{Y})$ & -- \\
\hline B-9 & FTP00133 & 9 & 10 & $13,000(\mathrm{~J})$ & -- & $4.6(\mathrm{Y})$ & -- \\
\hline B-10 & FTP00136 & 14 & 15 & $7,600(\mathrm{~J})$ & -- & $9.3(\mathrm{Y})$ & -- \\
\hline B-10 & FTP00139 & 34 & 35 & -- & -- & -- & 32 \\
\hline B-11 & FTP00145 & 19 & 20 & $3,000(\mathrm{~J})$ & -- & $58(Y)$ & -- \\
\hline B-12 & FTP00149 & 19 & 20 & $7,500(\mathrm{~J})$ & -- & $54(Y)$ & -- \\
\hline B-14 & FTP00154 & 24 & 25 & $18,000(\mathrm{~J})$ & -- & $3,000(\mathrm{~J})$ & -- \\
\hline B-14 & FTP00155 & 39 & 40 & 57 & -- & $11(\mathrm{~J})$ & -- \\
\hline B-16 & FTP00160 & 18.5 & 19 & $5,400(\mathrm{~J})$ & -- & $320(\mathrm{~J})$ & -- \\
\hline B-16 & FTP00161 & 33 & 34 & -- & -- & $2.5(\mathrm{~J})$ & 43 \\
\hline B-16 & FTP00162 & 54 & 55 & -- & -- & $13(\mathrm{~J})$ & -- \\
\hline B-17 & FTP00163 & 29 & 30 & -- & -- & $1.2(\mathrm{~J})$ & -- \\
\hline
\end{tabular}

-- = Not detected above minimum reporting limits

$\mathrm{J}=$ Estimated value

$\mathrm{Y}=$ The chromatogram patterns do not match the peak patterns

Shaded area $=$ Analytical result exceeds the $100 \mathrm{mg} / \mathrm{kg}$ NDEP established action level

The majority of the petroleum hydrocarbon contamination is confined to two general areas of the FTP: the burn pit and the fuel storage area (location of ASTs). These areas are depicted in the contaminant distribution diagram shown in Figure A.3-1. Contamination associated with site elements discussed in Table 3-1 of the CAIP (DOE/NV, 1998), as well as additional locations, is described in the following subsection.

\section{A.3.1.1 Aboveground Storage Tanks Area}

Diesel, gasoline, and unknown hydrocarbons were detected in the AST area. The contamination appears to have had at least three point sources: one at the former location of the rail car AST as 


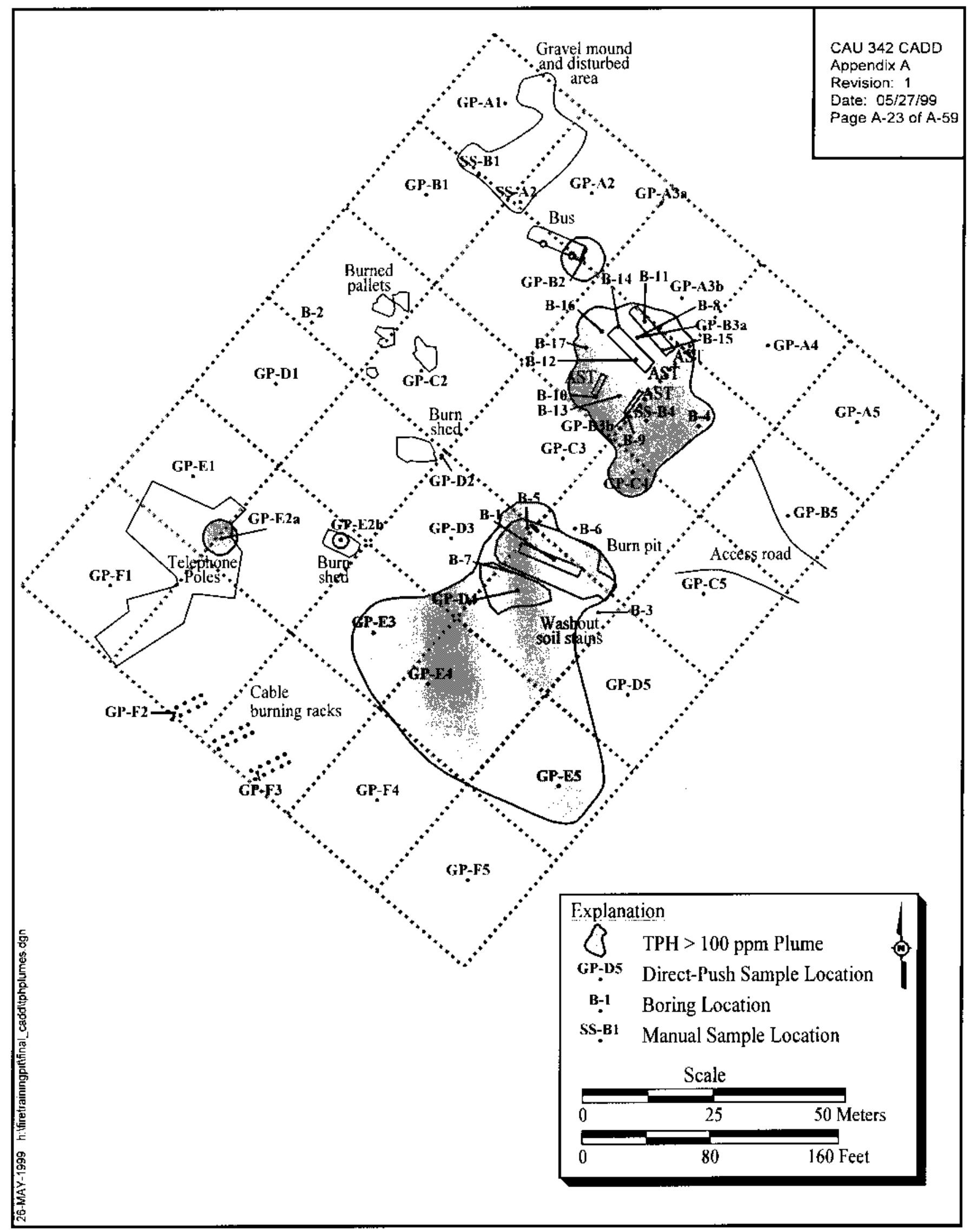

Figure A.3-1

Lateral Extent of the TPH Plumes at the Mercury Fire Training Pit 
evidenced by a surface soil stain and the other two are from the former locations of the small ASTs also evidenced by surface soil stains. No surface stain was evident in the former location of the "green tanker" AST. Each stain appears to be the result of leakage from the ASTs. Each of these sources appear to have contributed to a subsurface plume of contamination.

The source of the largest lobe of the plume appears to have been one or both of the large ASTs (rail car and green tanker [Figure A.2-1]) that were used at the FTP. A surface stain approximately $1 \mathrm{ft}$ in diameter was evident at the former location of the rail car. Samples were collected from the location of the stain by both direct-push equipment (GP-B3a) and subsurface drilling (B-8). Subsequent stepout borings (B-11, B-12, B-14, B-15, B16, And B-17) were drilled to asses the lateral and vertical extent of the plume. The maximum depth of this lobe of the plume is approximately $50-\mathrm{ft}$ bgs as shown in the interpretive cross sections shown in Figure A.3-2 and Figure A.3-3.

The sources of the two smaller lobes of the plume appear to have been the two small ASTs that were stored on site. Small surface stains were evident at the former location of each of the small ASTs. The easternmost of these stains was sampled by direct-push equipment (GP-B3b) and subsurface drilling (B-9). The westernmost stain was sampled by subsurface drilling (B-10). The maximum depth of the contamination is no greater than $20-\mathrm{ft}$ bgs from the easternmost stain and no more than $30-\mathrm{ft}$ bgs from the westernmost stain. The horizontal extent of these lobes of the plume is not well defined but is thought to have a radius no greater then the total depth of the contamination in this part of the plume. A single stepout boring (B-13) was drilled between B-9 and B-10. No TPH was detected in borehole B-13. This suggests that there are two or three plumes, not one continuous plume (Figure A.3-2 and Figure A.3-3). However, due to the proximity of the surrounding detections of TPH, the plumes are assumed to be contiguous for the purposes of modeling the lateral extent of the TPH contamination (Figure A.3-1).

As shown in Figure A.3-1, the combined lobes of the AST plume have a maximum length and width of approximately 130 by $80 \mathrm{ft}$.

\section{A.3.1.2 Burn Area Near Bus}

Four samples were obtained by direct-push equipment (GP-B1 and GP-A1) within the historical burn area near the bus. No petroleum hydrocarbons were detected above minimum reporting limits. 


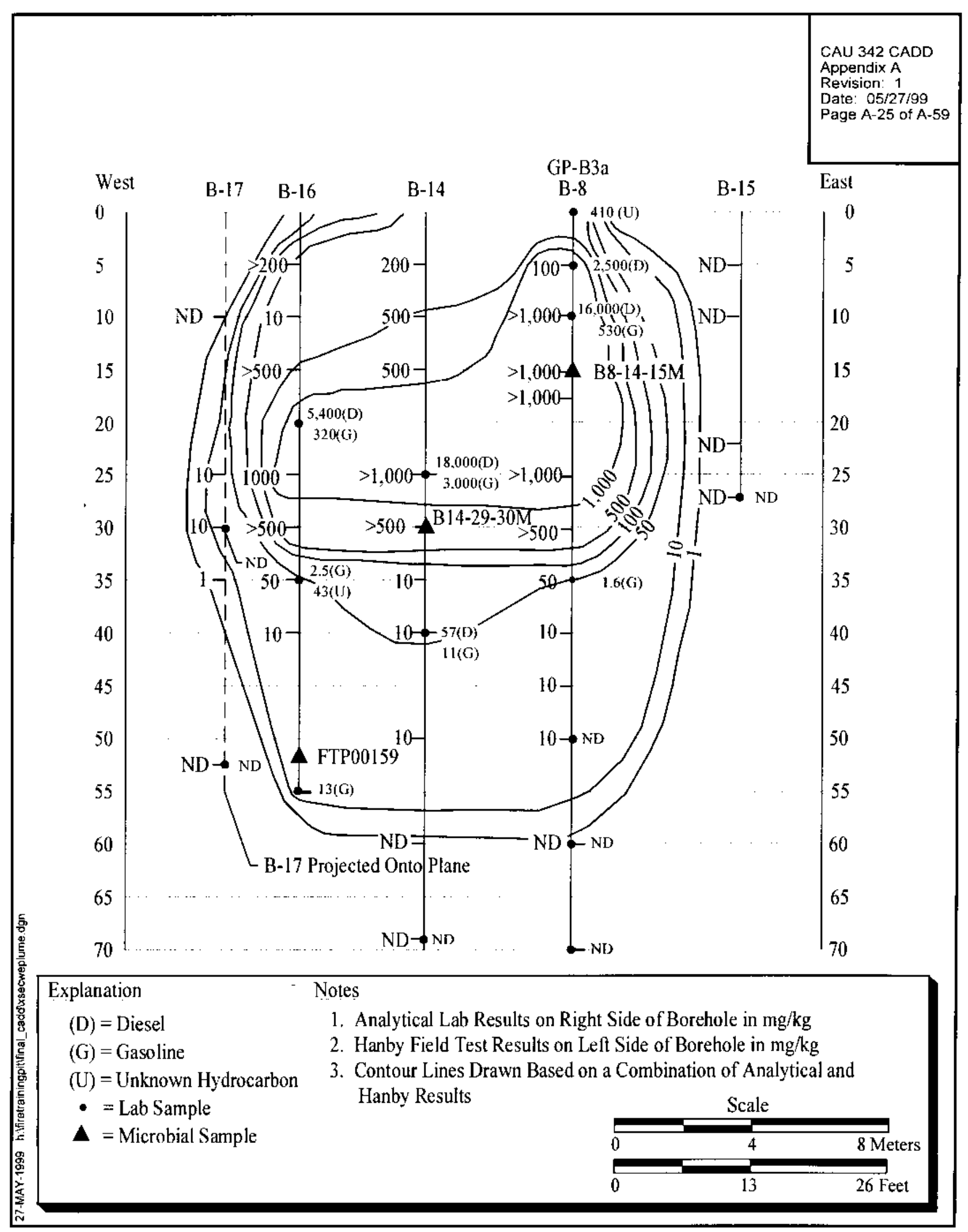

Figure A.3-2

Cross Section of AST Subsurface Plume (West/East) 


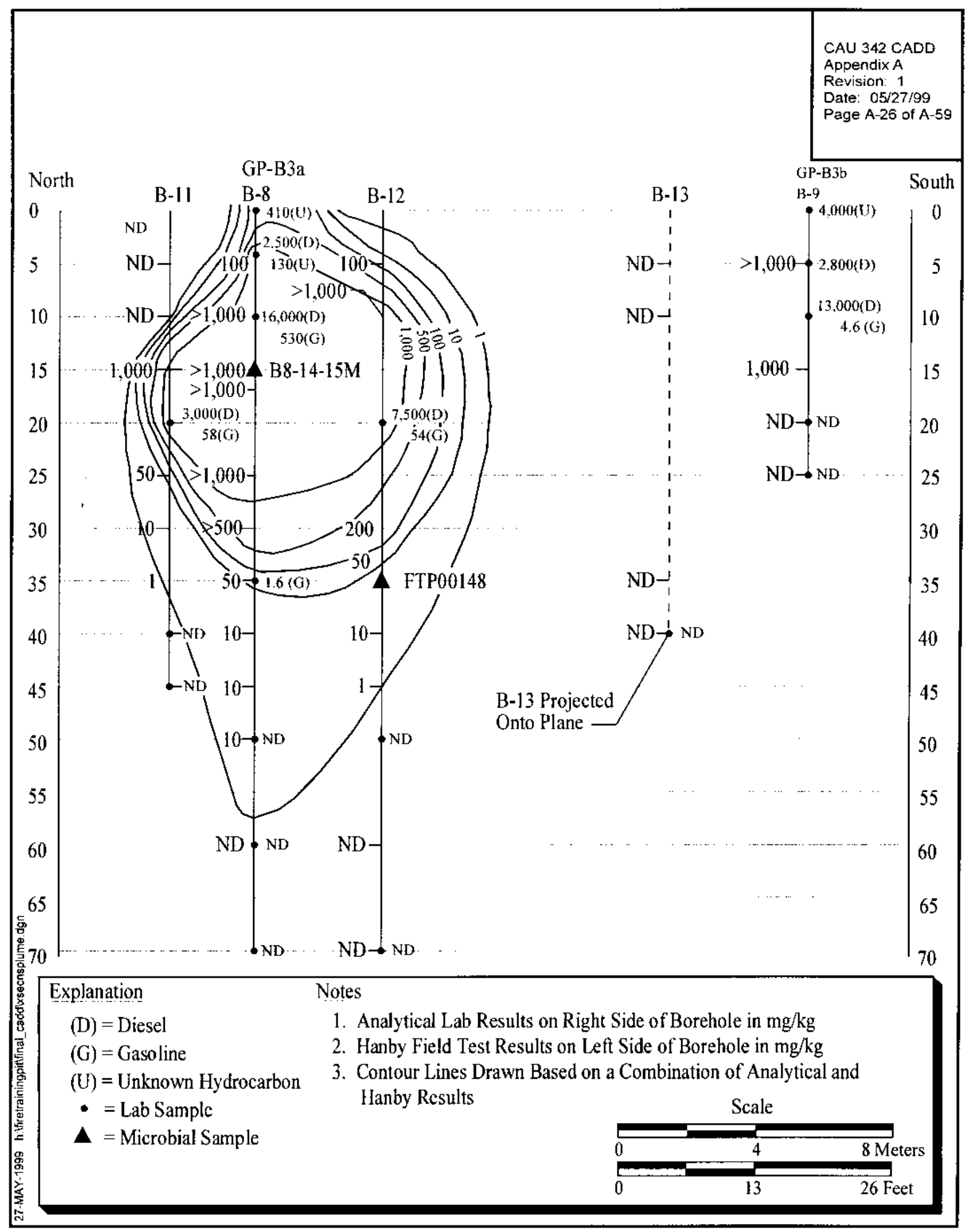

Figure A.3-3

Cross Section of AST Subsurface Plume (North/South) 
Borehole B-2 was drilled just south of this area in a spot identified by the passive soil gas survey as likely hydrocarbon contamination area (DOE/NV, 1998). No hydrocarbons were identified in samples collected from borehole B-2.

\section{A.3.1.3 Burn Pit}

Diesel, gasoline, and unknown hydrocarbons were detected in this area. The surface area inside the berm is heavily stained. Two boreholes (B-1 and B-5) were drilled inside the berm. Step-out boreholes were drilled on the south side berm (B-7), approximately $15 \mathrm{ft}$ from the southeast corner of the burn pit (B-3), and approximately $10 \mathrm{ft}$ from middle of the north side of the burn pit (B-6), as shown in Figure A.2-3. The contamination extends from the surface of the burn pit to a depth of approximately 30-ft bgs as shown in the interpretive cross section (Figure A.3-4). There was no TPH contamination detected above $100 \mathrm{mg} / \mathrm{kg}$ in the boreholes outside the berm. The plume is assumed to have the same approximate dimensions as the berm defining the burn pit. Therefore, the burn pit plume has a length (east - west) of approximately $65 \mathrm{ft}$ and a width (north - south) of approximately $27 \mathrm{ft}$. Surface contamination extends downgradient of the burn pit (Figure A.3-1) as discussed in Section A.3.1.8.

\section{A.3.1.4 Bus}

Two samples were obtained by direct-push (GP-B2) from a soil stain at the approximate former location of the bus. Waste oil was detected above the PALs in the sample collected at the 0 to $1 \mathrm{ft}$ bgs interval at this location. No petroleum hydrocarbons were detected above the minimum reporting limits in the sample collected from the 3- to 4-ft bgs interval.

\section{A.3.1.5 Cable Racks}

Four samples were obtained by direct-push (GP-F3 and GP-F2) from the former location of the cable racks. No petroleum hydrocarbons were detected above minimum reporting limits.

\section{A.3.1.6 Pallets and Wood Debris}

Two samples were obtained by direct-push (GP-C2) at the former location of the pallets and wood debris. No petroleum hydrocarbons were detected above minimum reporting limits. 


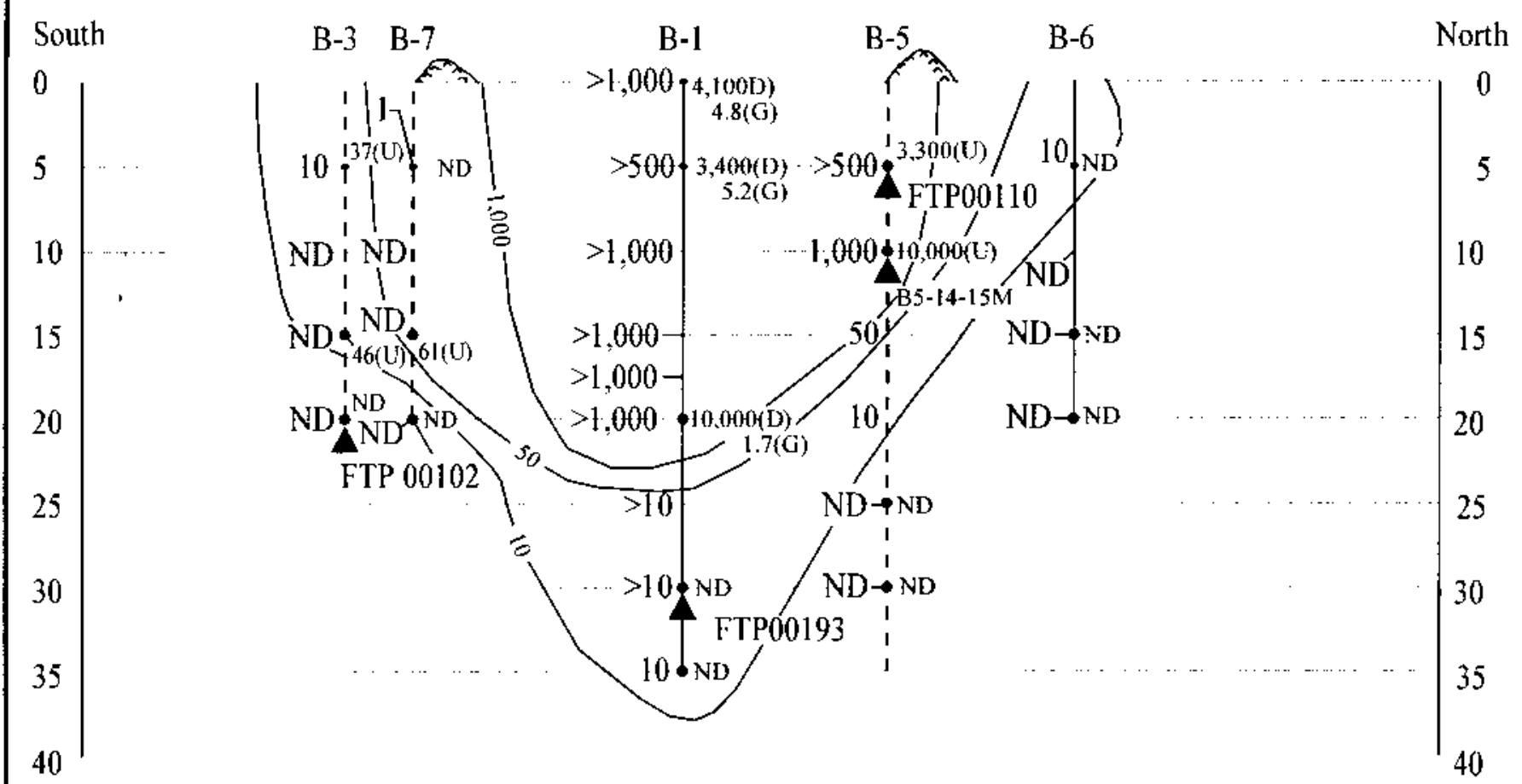

B-3, B-5, and B-7 Projected Onto Plane

Explanation

(D) $=$ Diesel

(G) = Gasoline

$(\mathrm{U})=$ Unknown

- = Lab Sample

$\boldsymbol{\Delta}$ = Microbial Sample
Notes

1. Analytical Lab Results on Right Side of Borehole in $\mathrm{mg} / \mathrm{kg}$

2. Hanby Field Test Results on Left Side of Borehole in $\mathrm{mg} / \mathrm{kg}$

3. Contour Lines Drawn Based on a Combination of Analytical and Hanby Results

Scale

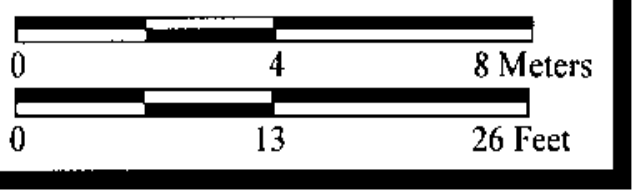

Figure A.3-4 Cross Section of Burn Pit Plume 


\section{A.3.1.7 Sheds}

Two samples were collected by direct-push (GP-E2b and GP-D2) from the former locations of the burn sheds. An unknown hydrocarbon was detected above the PAL in the sample collected at the 0- to 1-ft bgs interval at the GP-E2b location (southernmost shed). No petroleum hydrocarbons were detected above minimum reporting limits in the sample collected at the 3- to 4-ft bgs interval of the GP-E2b location or at either interval of the GP-D2 location (northernmost shed).

\section{A.3.1.8 Stained Soil Areas}

Several areas of surface staining not specifically covered under another heading were sampled. Two main areas of surface stains were sampled by direct-push: the area downgradient of the burn pit, and the area downgradient of the AST area. A small surface stain near the AST area was also sampled.

A total of 16 samples were obtained by direct-push in the area downgradient of the burn pit. Surface staining is evident in this area and is believed to have originated from overflow and surface runoff from the burn pit (Figure A.2-1). An unknown hydrocarbon was detected in both the 0- to 1-ft bgs and the 3- to 4-ft bgs intervals in direct-push locations GP-E5, GP-E4, GP-E3, and GP-D4 closest to the burn pit (Figure A.3-1). Sample location GP-E4 was located in the middle of a shallow natural drainage originating from the southwest corner of the burn pit (Figure A.2-1). No petroleum hydrocarbons were detected above minimum reporting limits at sample location GP-F4 which is further downgradient in the same natural drainage. No petroleum hydrocarbons were detected above minimum reporting limits in sample locations GP-F5, GP-F4, and GP-F2 which are also further downgradient (Figure A.3-1).

Four samples were obtained by direct-push in the area downgradient of the AST area. Surface staining is evident in this area and is believed to have originated from leaking hoses transferring fuel from the AST area to the burn pit and from surface runoff from the AST area (Figure A.2-1). Diesel was detected in the 0 - to 1 -ft bgs interval and an unknown hydrocarbon was detected in the 3- to 4-ft bgs interval at sample location GP-C4 (Figure A.3-1). No petroleum hydrocarbons were detected above minimum reporting limits at sample location GP-C3.

One sample was collected using hand collection methods from a surface stain to the east of the former locations of the small ASTs. The stain has a diameter of approximately $2 \mathrm{ft}$ and appears to be the 
result of a localized spill of oil or other heavy hydrocarbon. An unknown hydrocarbon was detected in the sample collected at this location (SS-B4).

The vertical extent of the contamination associated with these stains has not been defined; however, it is expected to be limited due to release mechanisms, surface grade, and low precipitation rates.

\section{A.3.1.9 Telephone Poles}

Two samples were obtained by direct-push (GP-E2a) at the former location of the telephone poles. Unknown hydrocarbons were detected above the PAL at the both the 0- to 1-ft and 3- to 4-ft bgs intervals at this location. Staining is evident in this area; however, it appears to be associated with debris from the telephone poles and not hydrocarbon staining.

\section{A.3.1.10 Tire Burn Area}

Two areas containing burned tire and other debris were sampled by direct-push (GP-A3a and GP-A3b). No petroleum hydrocarbons were detected above minimum reporting limits.

\section{A.3.1.11 Borehole B-4}

Borehole B-4 was drilled at the center of the area identified in the CAIP as a possible chlorinated hydrocarbon plume based on the soil gas survey (DOE/NV, 1998). Waste oil was detected above the PAL in the sample collected from the 14- to 15-ft bgs interval and diesel was detected above the PAL in the sample collected from the 19- to 20 -ft bgs interval. No samples were collected from lower depths because field screening results were negative (nondetects). No chlorinated hydrocarbons were identified in samples collected from this borehole.

\section{A.3.2 Total Volatile Organic Compound Analytical Results}

The total VOC analytical results above the minimum reporting limits (DOE/NV, 1998), along with the associated PALs, are presented in Table A.3-3. Data indicate that constituents were either not present above the minimum reporting limits or, if present, were below the PALs, except for one sample in which xylene was detected above the PAL. 
Table A.3-3

Soil Sample Results for Total Volatile Organic Compounds Detected Above the Minimum Reporting Limit, Mercury Fire Training Pit, Nevada Test Site

(Page 1 of 3)

\begin{tabular}{|c|c|c|c|c|c|c|c|c|c|c|c|c|c|c|c|c|}
\hline \multirow[b]{2}{*}{ 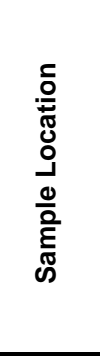 } & \multirow[b]{2}{*}{ 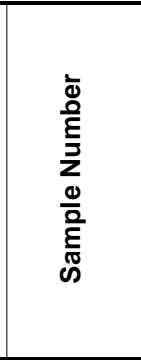 } & \multirow[b]{2}{*}{ 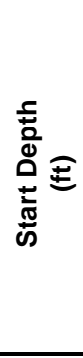 } & \multirow[b]{2}{*}{ 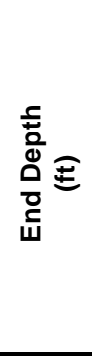 } & \multicolumn{13}{|c|}{ Contaminant of Potential Concern $(\mu \mathrm{g} / \mathrm{kg})$} \\
\hline & & & & 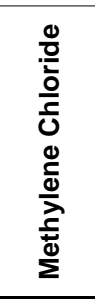 & 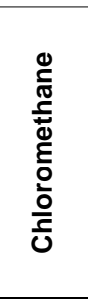 & 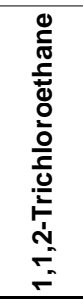 & 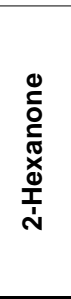 & $\frac{\underline{r}}{\underline{\underline{\Sigma}}}$ & 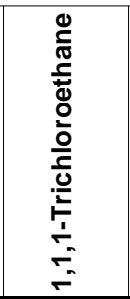 & 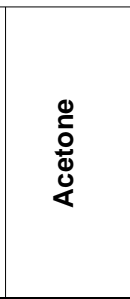 & 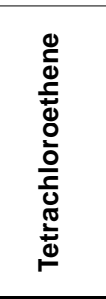 & 觉 & $\begin{array}{l}\stackrel{0}{0} \\
\stackrel{0}{0} \\
\stackrel{0}{\varrho}\end{array}$ & 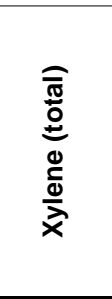 & 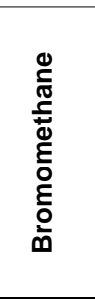 & 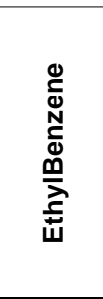 \\
\hline \multicolumn{4}{|c|}{ Preliminary Action Levels ${ }^{a}$} & 18,000 & 2,600 & 1,500 & $\mathbf{N I}$ & $2,800,000$ & $3,000,000$ & $8,800,000$ & 17,000 & $27,000,000$ & 880,000 & 320,000 & 23,000 & 230,000 \\
\hline GP-F2 & FTP00011 & 0 & 1 & $42(B)$ & $\overline{--}$ & $\overline{--}$ & $\overline{--}$ & $\overline{--}$ & $\overline{--}$ & $\overline{--}$ & $\overline{--}$ & $\overline{--}$ & -- & -- & -- & $\overline{--}$ \\
\hline GP-E2a & FTP00020 & 0 & 1 & $39(\mathrm{~B})$ & -- & -- & -- & -- & -- & -- & -- & -- & -- & -- & -- & -- \\
\hline GP-E2b & FTP00022 & 0 & 1 & $34(B)$ & $6(\mathrm{~J})$ & -- & -- & -- & -- & -- & -- & -- & -- & -- & -- & -- \\
\hline GP-E3 & FTP00024 & 0 & 1 & $39(\mathrm{~B})$ & -- & -- & -- & -- & -- & -- & -- & -- & -- & -- & -- & -- \\
\hline GP-E4 & FTP00026 & 0 & 1 & $46(B)$ & -- & -- & -- & -- & -- & -- & -- & -- & -- & -- & -- & -- \\
\hline GP-E5 & FTP00028 & 0 & 1 & $43(B)$ & -- & -- & -- & -- & -- & -- & -- & -- & -- & -- & - & -- \\
\hline GP-D5 & FTP00032 & 0 & 1 & -- & -- & -- & $7(\mathrm{~J})$ & $6(\mathrm{~J})$ & -- & -- & -- & -- & -- & -- & -- & -- \\
\hline GP-D5 & FTP00033 & 3 & 4 & -- & -- & -- & -- & -- & -- & -- & -- & -- & -- & -- & -- & - \\
\hline GP-D3 & FTP00037 & 0 & 1 & 40 (B) & -- & -- & -- & -- & -- & -- & -- & -- & -- & -- & -- & -- \\
\hline GP-C3 & FTP00047 & 3 & 4 & $41(\mathrm{~J})$ & -- & -- & -- & -- & -- & $76(\mathrm{~J})$ & -- & -- & -- & -- & -- & -- \\
\hline GP-C4 & FTP00048 & 0 & 1 & -- & -- & -- & -- & -- & 7 & -- & -- & -- & -- & -- & -- & -- \\
\hline GP-C4 & FTP00049 & 3 & 4 & -- & -- & -- & -- & -- & 51 & -- & 8 & -- & -- & -- & -- & -- \\
\hline GP-C5 & FTP00051 & 3 & 4 & $31(\mathrm{~J})$ & -- & -- & -- & -- & -- & -- & -- & -- & -- & -- & -- & -- \\
\hline GP-B3b & FTP00055 & 0 & 1 & -- & -- & -- & -- & -- & 12 & -- & $20(\mathrm{~J})$ & -- & -- & -- & -- & -- \\
\hline GP-B3b & FTP00056 & 3 & 4 & -- & -- & -- & -- & -- & 34 & -- & $100(\mathrm{~J})$ & -- & -- & -- & -- & -- \\
\hline GP-B3a & FTP00058 & 3 & 4 & -- & -- & -- & -- & -- & -- & -- & $6(\mathrm{~J})$ & -- & -- & -- & -- & -- \\
\hline GP-A3b & FTP00074 & 3 & 4 & $6(\mathrm{~B})$ & -- & -- & -- & -- & -- & $32(\mathrm{~B})$ & -- & 14 (BJ) & -- & -- & - & - \\
\hline SS-B4 & FTP00086 & 0 & 1 & -- & -- & -- & -- & $8(\mathrm{~J})$ & 13 & $120(\mathrm{~J})$ & $34(\mathrm{~J})$ & -- & -- & -- & -- & -- \\
\hline
\end{tabular}


Table A.3-3

Soil Sample Results for Total Volatile Organic Compounds Detected Above the Minimum Reporting Limit, Mercury Fire Training Pit, Nevada Test Site

(Page 2 of 3)

\begin{tabular}{|c|c|c|c|c|c|c|c|c|c|c|c|c|c|c|c|c|}
\hline \multirow[b]{2}{*}{ 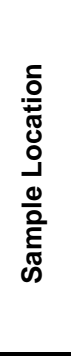 } & \multirow[b]{2}{*}{ 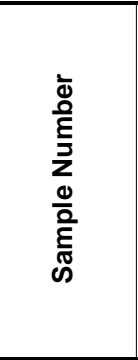 } & \multirow[b]{2}{*}{ 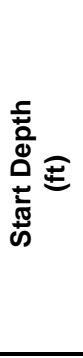 } & \multirow[b]{2}{*}{ 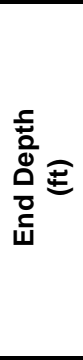 } & \multicolumn{13}{|c|}{ Contaminant of Potential Concern $(\mu \mathrm{g} / \mathrm{kg})$} \\
\hline & & & & 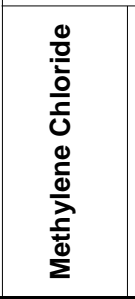 & 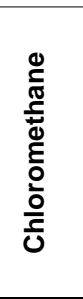 & 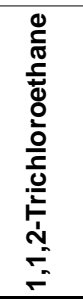 & 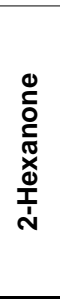 & $\frac{\underline{r}}{\underline{\underline{\Sigma}}}$ & 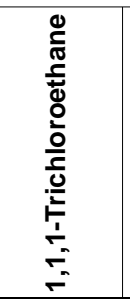 & $\begin{array}{l}\stackrel{0}{c} \\
\stackrel{0}{0} \\
\stackrel{0}{4}\end{array}$ & 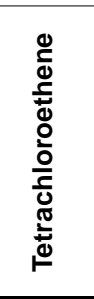 & 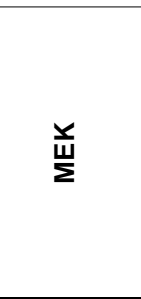 & $\begin{array}{l}\stackrel{0}{\bar{D}} \\
\stackrel{0}{0}\end{array}$ & 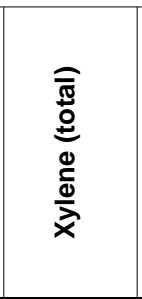 & 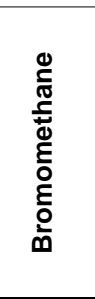 & 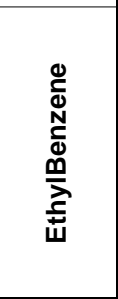 \\
\hline \multicolumn{4}{|c|}{ Preliminary Action Levels ${ }^{a}$} & 18,000 & 2,600 & 1,500 & NI & $2,800,000$ & $3,000,000$ & $8,800,000$ & 17,000 & $27,000,000$ & 880,000 & 320,000 & 23,000 & 230,000 \\
\hline $\mathrm{B}-1$ & FTP00089 & 0 & 1 & $8(\mathrm{~J})$ & $\overline{--}$ & -- & -- & $\overline{--}$ & $\overline{--}$ & $350(\mathrm{~J})$ & -- & $68(\mathrm{~J})$ & -- & -- & $\overline{--}$ & -- \\
\hline B-1 & FTP00091 & 4 & 5 & 28 & -- & -- & -- & -- & 38 & $190(\mathrm{~J})$ & -- & $67(\mathrm{~J})$ & $6(\mathrm{~J})$ & -- & -- & -- \\
\hline B-1 & FTP00094 & 19 & 20 & $13(\mathrm{~J})$ & -- & 98 & -- & -- & $9(\mathrm{~J})$ & -- & -- & -- & -- & -- & -- & -- \\
\hline B-1 & FTP00095 & 29 & 30 & -- & -- & 40 & -- & -- & -- & -- & -- & -- & -- & -- & -- & -- \\
\hline B-1 & FTP00096 & 34 & 35 & -- & -- & $10(\mathrm{~J})$ & -- & -- & -- & -- & -- & -- & -- & -- & -- & -- \\
\hline B-2 & FTP00099 & 0 & 5 & 8 & -- & -- & -- & -- & -- & -- & -- & -- & -- & -- & -- & -- \\
\hline B-2 & FTP00100 & 9 & 10 & 7 & -- & -- & -- & -- & -- & -- & -- & -- & -- & -- & -- & -- \\
\hline B-2 & FTP00101 & 14 & 15 & -- & -- & -- & -- & -- & -- & -- & -- & -- & -- & -- & $34(\mathrm{~J})$ & -- \\
\hline B-3 & FTP00103 & 4 & 5 & -- & -- & -- & -- & -- & -- & -- & -- & -- & -- & -- & $39(\mathrm{~J})$ & -- \\
\hline B-4 & FTP00109 & 19 & 20 & -- & -- & -- & -- & -- & -- & -- & -- & -- & -- & -- & $16(\mathrm{~J})$ & -- \\
\hline B-5 & FTP00112 & 9 & 10 & -- & -- & $9(\mathrm{~J})$ & -- & -- & 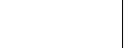 & -- & -- & -- & -- & -- & -- & -- \\
\hline B-5 & FTP00114 & 29 & 30 & -- & -- & 6 & -- & -- & -- & -- & -- & -- & -- & -- & -- & -- \\
\hline B-6 & FTP00120 & 4 & 5 & -- & -- & -- & -- & -- & -- & -- & -- & -- & -- & -- & -- & -- \\
\hline B-8 & FTP00128 & 9 & 10 & 3,000 (BJ) & -- & -- & -- & -- & -- & $43,000(\mathrm{~J})$ & -- & -- & -- & 25,000 (J) & -- & -- \\
\hline B-8 & FTP00129 & 34 & 35 & -- & -- & -- & -- & -- & -- & -- & -- & -- & -- & -- & -- & -- \\
\hline B-10 & FTP00137 & 29 & 30 & -- & -- & -- & -- & -- & -- & -- & -- & -- & -- & 53 & -- & -- \\
\hline B-12 & FTP00150 & 49 & 50 & -- & -- & -- & -- & -- & -- & -- & -- & -- & -- & $1,800(\mathrm{~J})$ & -- & -- \\
\hline B-14 & FTP00154 & 24 & 25 & -- & -- & -- & -- & -- & -- & -- & -- & -- & $47,000(\mathrm{~J})$ & $480,000(\mathrm{~J})$ & -- & $58,000(\mathrm{~J})$ \\
\hline
\end{tabular}


Table A.3-3

Soil Sample Results for Total Volatile Organic Compounds Detected Above the Minimum Reporting Limit, Mercury Fire Training Pit, Nevada Test Site

(Page 3 of 3)

\begin{tabular}{|c|c|c|c|c|c|c|c|c|c|c|c|c|c|c|c|c|}
\hline \multirow[b]{2}{*}{ 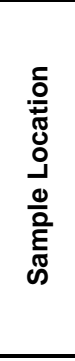 } & \multirow[b]{2}{*}{ 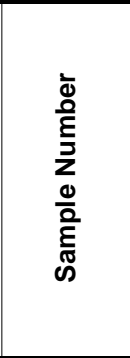 } & \multirow[b]{2}{*}{ 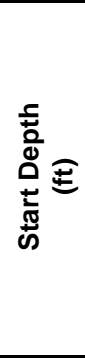 } & \multirow[b]{2}{*}{ 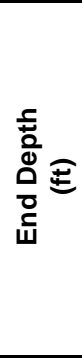 } & \multicolumn{13}{|c|}{ Contaminant of Potential Concern $(\mu \mathrm{g} / \mathrm{kg})$} \\
\hline & & & & 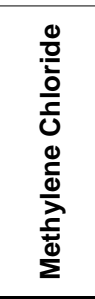 & 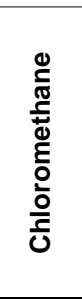 & 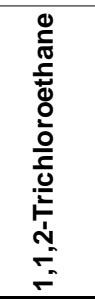 & 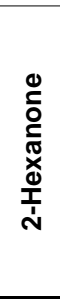 & $\frac{\underline{\mathbf{r}}}{\underline{\underline{\Sigma}}}$ & 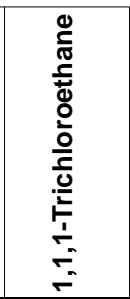 & $\begin{array}{l}0 \\
\stackrel{0}{0} \\
\stackrel{0}{0} \\
\stackrel{0}{<}\end{array}$ & 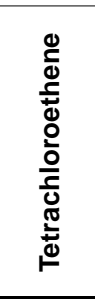 & 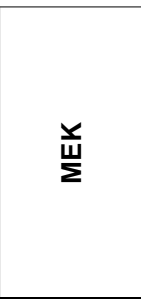 & 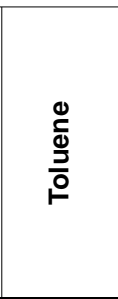 & 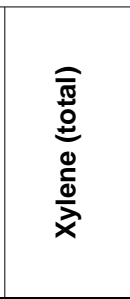 & 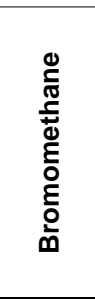 & 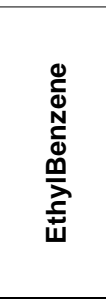 \\
\hline \multicolumn{4}{|c|}{ Preliminary Action Levels ${ }^{a}$} & 18,000 & 2,600 & 1,500 & NI & $2,800,000$ & $3,000,000$ & $8,800,000$ & 17,000 & $27,000,000$ & 880,000 & 320,000 & 23,000 & 230,000 \\
\hline B-15 & FTP00157 & 26 & 27 & $\overline{---}$ & $\overline{---}$ & -- & -- & $\overline{---}$ & $\overline{---}$ & $\overline{---}$ & -- & -- & $\overline{---}$ & $7(\mathrm{~J})$ & -- & $\overline{---}$ \\
\hline B-16 & FTP00160 & 18.5 & 19 & -- & $15(\mathrm{~J})$ & -- & -- & -- & -- & -- & -- & -- & $4,900(\mathrm{~J})$ & $44,000(\mathrm{~J})$ & -- & $6,900(\mathrm{~J})$ \\
\hline B-16 & FTP00161 & 33 & 34 & -- & -- & -- & -- & -- & -- & -- & -- & -- & -- & 120 & -- & -- \\
\hline B-16 & FTP00162 & 54 & 55 & -- & -- & -- & -- & -- & -- & $16(\mathrm{~J})$ & -- & -- & -- & -- & -- & -- \\
\hline B-17 & FTP00163 & 29 & 30 & -- & -- & -- & -- & -- & -- & $10(\mathrm{~J})$ & -- & -- & -- & 56 & -- & -- \\
\hline B-17 & FTP00164 & 51.5 & 52.5 & -- & -- & -- & -- & -- & -- & $31(\mathrm{~J})$ & -- & -- & -- & -- & -- & -- \\
\hline
\end{tabular}

${ }^{a}$ Environmental Protection Agency Region IX, Industrial PRG (EPA, 1996a)

$\mathrm{NI}=$ Not identified

$\mathrm{BJ}=$ Analyte found in associated blank; estimated value

$\mathrm{J}=$ Estimated value

$\mathrm{B}=$ Analyte found in associated blank

-- = Not detected above minimum reporting limit

Darker shaded area $=$ Analytical result exceeds the preliminary action level 
Xylene was detected in boreholes B-8, B-10, B-12, B-14, B-15, B-16, and B-17. The highest detections $(>10,000$ micrograms per kilogram $[\mu \mathrm{g} / \mathrm{kg}])$ were recorded within the center of the large lobe of the AST area hydrocarbon plume. The lone sample in which xylene (B-14, 24- to 25-ft bgs) was detected above the PAL corresponds with the highest TPH detection suggesting that the xylene is limited to only the highest hydrocarbon contaminated zones of the AST plume.

Ethylbenzene and toluene were detected in boreholes B-14 and B-16 also corresponding to the area of highest petroleum hydrocarbon contamination in the AST plume.

Acetone, methylene chloride, and methylethyl ketone (MEK) were detected at very low levels indicative of laboratory contamination. With the exception of detections of acetone and methylene chloride in elevated levels in one sample (FTP00128) from the 9- to 10-ft bgs interval in borehole B-8, the detections of these three compounds do not correspond to any other elevated constituents detected during this investigation. One detection of toluene (B-1, 4- to 5-ft bgs) also falls into this description.

Other VOCs detected during the investigation are limited to methylene chloride; chloromethane; 1,1,2-trichloroethane; 2-hexanone; methyl isobutyl ketone (MIBK); 1,1,1-trichloroethane; acetone; tetrachloroethane; and bromomethane. In most cases, the detections correspond to samples in which hydrocarbons were detected.

In all cases except for the one xylene detection described above, the levels detected were below the PALs.

\section{A.3.3 TCLP Volatile Organic Compounds Analytical Results}

Three samples (FTP00089, FTP00091, and FTP00107) were analyzed for TCLP VOCs to support waste management decisions. Sample FTP00107 was collected at a location (B-4, 4- to 5-ft bgs) identified in the CAIP (DOE/NV, 1998) as a likely place for chlorinated hydrocarbon contamination. Samples FTP00089 and FTP00091 were collected from B-1 at 0- to 1-ft bgs and 4- to 5-ft bgs, respectively. No constituents were identified above RCRA regulatory levels in any of these samples. No VOCs were identified in this sample, or in other samples from borehole B-4 or borehole B-1, above PALs. 


\section{A.3.4 Total Semivolatile Organic Compound Analytical Results}

The total SVOC analytical results above minimum reporting limits (DOE/NV, 1998), along with the associated PALs, are presented in Table A.3-4. The laboratory data indicate that constituents were either not present above the minimum reporting limits, or if present, were present below the PALs.

Detected SVOCs were identified within the TPH contaminated areas described in Section A.3.1 and probably represent chemicals associated with TPH constituents and degradation products.

\section{A.3.5 Total RCRA Metals and Zinc Analytical Results}

The total RCRA metals and zinc detected above the minimum reporting limits are presented in Table A.3-5. Arsenic was detected above the PAL of $2.4 \mathrm{mg} / \mathrm{kg}$ in all of the samples analyzed. The arsenic concentrations for the samples analyzed ranged from $2.5 \mathrm{mg} / \mathrm{kg}$ to $5.9 \mathrm{mg} / \mathrm{kg}$ with two exceptions; samples FTP00021 and FTP00054 had the highest arsenic concentrations of $10.8 \mathrm{mg} / \mathrm{kg}$ and $7.0 \mathrm{mg} / \mathrm{kg}$, respectively. Although these concentrations exceed the PAL for arsenic, these concentrations are not unusual for the State of Nevada (Shacklette and Boerngen, 1984) and are considered representative of ambient conditions.

\section{A.3.6 TCLP Metals Analytical Results}

The TCLP metals detected above the minimum reporting limits are presented in Table A.3-6. These samples were taken to support waste characterization decisions. Originally, only two samples (FTP00089 and FTP00091), collected at the top of borehole B-1, were analyzed for TCLP metals. This was considered to be the most likely location to find RCRA metals above the maximum toxicity characteristic limits based on sample results of the residue that was found inside the burn tank (DOE/NV, 1998). Cadmium was detected above the regulatory limit of $1 \mathrm{mg} / \mathrm{L}$ (CFR, 1998) in both samples. Cadmium was not detected above the minimum reporting limits for total metals analysis in either of these samples.

Additional samples from within the burn pit (FTP00094, FTP00111, and FTP00112) as well as other samples containing high diesel concentrations were analyzed for TCLP metals. No cadmium or other RCRA metals were detected in these samples above the toxicity characteristic limits. This suggests one of the following conclusions: matrix interference (high diesel concentration) masked the 
Table A.3-4

Soil Sample Results for Total Semivolatile Organic Compounds Detected Above Minimum Reporting Limits, Mercury Fire Training Pit, Nevada Test Site

\begin{tabular}{|c|c|c|c|c|c|c|c|c|c|c|c|}
\hline \multirow[b]{2}{*}{ 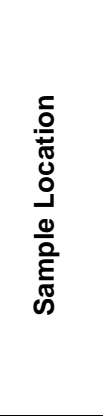 } & \multirow[b]{2}{*}{ 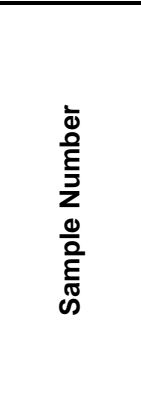 } & \multirow[b]{2}{*}{ 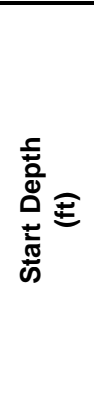 } & \multirow[b]{2}{*}{ 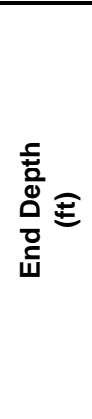 } & \multicolumn{8}{|c|}{ Contaminant of Potential Concern $(\mu \mathrm{g} / \mathbf{k g})$} \\
\hline & & & & 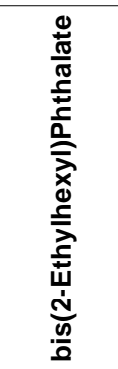 & 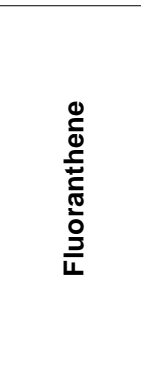 & 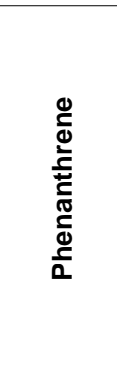 & 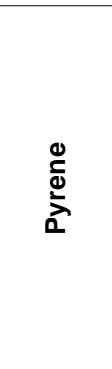 & 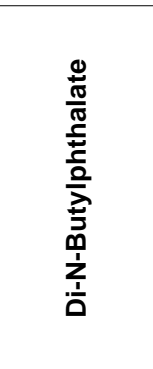 & 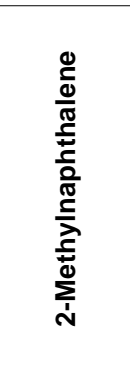 & 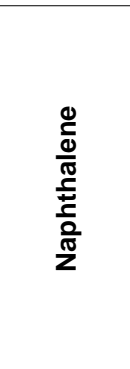 & 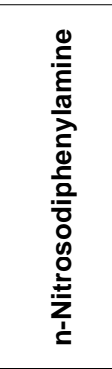 \\
\hline \multicolumn{4}{|c|}{ Preliminary Action Levels ${ }^{a}$} & 140,000 & $27,000,000$ & $\mathbf{N I}$ & 100,000 & $68,000,000$ & $\mathbf{N I}$ & 240,000 & 390,000 \\
\hline GP-F2 & FTP00011 & 0 & 1 & 720 & $\overline{---}$ & -- & -- & $\overline{--}$ & -- & -- & -- \\
\hline GP-E2a & FTP00020 & 0 & 1 & -- & 2,100 & 2,100 & 1,400 & -- & -- & -- & -- \\
\hline GP-E4 & FTP00026 & 0 & 1 & 1,700 & -- & -- & -- & -- & -- & -- & -- \\
\hline GP-C4 & FTP00048 & 0 & 1 & -- & -- & -- & -- & $220(\mathrm{~J})$ & -- & -- & -- \\
\hline GP-B3a & FTP00057 & 0 & 1 & -- & -- & -- & -- & $230(\mathrm{~J})$ & -- & -- & -- \\
\hline GP-B3a & FTP00059 & 0 & 1 & -- & -- & -- & -- & -- & -- & -- & -- \\
\hline GP-B2 & FTP00062 & 0 & 1 & -- & -- & -- & -- & $230(\mathrm{~J})$ & -- & -- & -- \\
\hline B-8 & FTP00128 & 9 & 10 & -- & -- & $4,600(\mathrm{~J})$ & -- & -- & $1,4000(\mathrm{~J})$ & $7,800(\mathrm{~J})$ & $4,700(\mathrm{~J})$ \\
\hline B-8 & FTP00132 & 69 & 70 & -- & -- & -- & -- & $150(\mathrm{~J})$ & -- & -- & -- \\
\hline B-9 & FTP00133 & 9 & 10 & $1,200(\mathrm{~J})$ & -- & 4,000 & -- & -- & 9,800 & $2,900(\mathrm{~J})$ & -- \\
\hline B-10 & FTP00136 & 14 & 15 & -- & -- & $1,800(\mathrm{~J})$ & -- & -- & -- & -- & -- \\
\hline B-11 & FTP00145 & 19 & 20 & -- & -- & -- & -- & -- & 7,900 & 4,100 & -- \\
\hline B-12 & FTP00149 & 19 & 20 & -- & -- & -- & -- & -- & -- & 3,500 & -- \\
\hline B-14 & FTP00154 & 24 & 25 & -- & -- & -- & -- & -- & $35,000(\mathrm{~J})$ & $19,000(\mathrm{~J})$ & -- \\
\hline B-16 & FTP00160 & 18.5 & 19 & -- & -- & -- & -- & -- & $11,000(\mathrm{~J})$ & $5,500(\mathrm{~J})$ & -- \\
\hline B-16 & FTP00160 & 18.5 & 19 & -- & -- & -- & -- & -- & $3,800(E)$ & $4,200(E)$ & -- \\
\hline
\end{tabular}

aU.S. Environmental Protection Agency Region IX, Industrial PRGs (EPA, 1996a)

$\mathrm{E}=$ Compound concentration exceeds calibration range

$\mathrm{J}=$ Estimated value

-- = Not detected above minimum reporting limit

$\mathrm{NI}=$ Not identified

$\mu \mathrm{g} / \mathrm{kg}=$ Microgram per kilogram 
Table A.3-5

Soil Sample Results for Total RCRA Metals and Zinc Detected Above Minimum Reporting Limits, Mercury Fire Training Pit, Nevada Test Site (Page 1 of 5 )

\begin{tabular}{|c|c|c|c|c|c|c|c|c|c|}
\hline \multirow{2}{*}{$\begin{array}{l}\text { Sample } \\
\text { Location }\end{array}$} & \multirow{2}{*}{$\begin{array}{l}\text { Sample } \\
\text { Number }\end{array}$} & \multirow{2}{*}{$\begin{array}{c}\text { Start } \\
\text { Depth } \\
\text { (ft) }\end{array}$} & \multirow{2}{*}{$\begin{array}{l}\text { End } \\
\text { Depth } \\
\text { (ft) }\end{array}$} & \multicolumn{6}{|c|}{ Contaminant of Potential Concern $(\mathrm{mg} / \mathrm{kg})$} \\
\hline & & & & Arsenic & Barium & Chromium & Lead & Mercury & Zinc \\
\hline \multicolumn{4}{|c|}{ Preliminary Action Levels ${ }^{a}$} & 2.4 & 100,000 & 450 & 1,000 & 510 & 100,000 \\
\hline GP-F5 & FTP00004 & 0 & 1 & $4.7(\mathrm{~J})$ & 103 & $9.4(\mathrm{~J})$ & $8.5(\mathrm{~J})$ & -- & 39.6 \\
\hline GP-F5 & FTP00005 & 3 & 4 & $4.4(J)$ & 67.5 & $5.1(\mathrm{~J})$ & $3.5(\mathrm{~J})$ & -- & 12.2 \\
\hline GP-F4 & FTP00006 & 0 & 1 & $4.4(J)$ & 103 & $6.7(\mathrm{~J})$ & $7.8(\mathrm{~J})$ & -- & 20.4 \\
\hline GP-F4 & FTP00007 & 3 & 4 & $5.4(\mathrm{~J})$ & 46.7 & $4.0(\mathrm{~J})$ & $6.6(\mathrm{~J})$ & -- & 6.5 \\
\hline GP-F3 & FTP00008 & 0 & 1 & $3.9(\mathrm{~J})$ & 90.9 & $7.1(\mathrm{~J})$ & $5.6(\mathrm{~J})$ & -- & 18.0 \\
\hline GP-F3 & FTP00009 & 3 & 4 & $3.6(\mathrm{~J})$ & 40.1 & $3.7(\mathrm{~J})$ & $2.8(\mathrm{~J})$ & -- & 6.6 \\
\hline GP-F3 & FTP00010 & 0 & 1 & $4.4(\mathrm{~J})$ & 101 & $9.2(\mathrm{~J})$ & $21.3(\mathrm{~J})$ & -- & 28.0 \\
\hline GP-F2 & FTP00011 & 0 & 1 & $5.3(\mathrm{~J})$ & 328 & 15.1 (J) & $318(\mathrm{~J})$ & -- & $88.0(\mathrm{~J})$ \\
\hline GP-F2 & FTP00012 & 3 & 4 & $5.3(\mathrm{~J})$ & 34.9 & $7.2(\mathrm{~J})$ & $2.8(\mathrm{~J})$ & -- & 5.9 \\
\hline GP-F1 & FTP00013 & 0 & 1 & $4.3(\mathrm{~J})$ & 73.2 & $6.2(\mathrm{~J})$ & $3.8(\mathrm{~J})$ & -- & 13.7 \\
\hline GP-F1 & FTO00014 & 3 & 4 & $5.1(\mathrm{~J})$ & 61.8 & $3.4(\mathrm{~J})$ & $2.2(\mathrm{~J})$ & -- & 6.5 \\
\hline GP-E1 & FTP00018 & 0 & 1 & $3.6(\mathrm{~J})$ & 74.5 & $5.1(\mathrm{~J})$ & $3.6(\mathrm{~J})$ & -- & 12.6 \\
\hline GP-E1 & FTP00019 & 3 & 4 & $4.6(\mathrm{~J})$ & 64.0 & $4.6(\mathrm{~J})$ & $3.1(\mathrm{~J})$ & -- & 10.5 \\
\hline GP-E2a & FTP00020 & 0 & 1 & $5.4(\mathrm{~J})$ & 107 & $10.1(\mathrm{~J})$ & $13.6(\mathrm{~J})$ & -- & 48.3 \\
\hline GP-E2a & FTP00021 & 3 & 4 & $10.8(\mathrm{~J})$ & 54.3 & $4.5(\mathrm{~J})$ & $2.4(\mathrm{~J})$ & -- & 6.4 \\
\hline GP-E2b & FTP00022 & 0 & 1 & $4.6(\mathrm{~J})$ & 102 & $8.0(\mathrm{~J})$ & 7.7 (J) & -- & 28.6 \\
\hline GP-E2b & FTP00023 & 3 & 4 & $3.1(\mathrm{~J})$ & 28.6 & $2.8(\mathrm{~J})$ & $1.7(\mathrm{~J})$ & -- & 4.1 \\
\hline GP-E3 & FTP00024 & 0 & 1 & $5.5(\mathrm{~J})$ & 93.5 & $8.3(\mathrm{~J})$ & $8.3(\mathrm{~J})$ & -- & 23.7 \\
\hline GP-E3 & FTP00025 & 3 & 4 & $3.0(\mathrm{~J})$ & 32.4 & $2.6(\mathrm{~J})$ & $1.8(\mathrm{~J})$ & -- & $2.6(\mathrm{~J})$ \\
\hline GP-E4 & FTP00026 & 0 & 1 & $5.9(\mathrm{~J})$ & 88.8 & 10.3 (J) & $9.6(\mathrm{~J})$ & -- & 32.9 \\
\hline GP-E4 & FTP00027 & 3 & 4 & $4.1(\mathrm{~J})$ & 45.5 & $3.1(\mathrm{~J})$ & $3.7(\mathrm{~J})$ & -- & 4.5 \\
\hline GP-E5 & FTP00028 & 0 & 1 & $4.4(\mathrm{~J})$ & 107 & $11.2(\mathrm{~J})$ & $7.1(\mathrm{~J})$ & -- & 28.1 \\
\hline GP-E5 & FTP00029 & 3 & 4 & $2.9(\mathrm{~J})$ & 46.7 & $3.8(\mathrm{~J})$ & $2.3(\mathrm{~J})$ & -- & 11.2 \\
\hline GP-D5 & FTP00032 & 0 & 1 & $4.9(\mathrm{~J})$ & 97.1 & $9.3(\mathrm{~J})$ & $6.9(\mathrm{~J})$ & -- & 27.9 \\
\hline GP-D5 & FTP00033 & 3 & 4 & $3.9(\mathrm{~J})$ & 46.4 & $3.4(\mathrm{~J})$ & $2.4(\mathrm{~J})$ & -- & 6.1 \\
\hline GP-D4 & FTP00034 & 0 & 1 & $3.0(\mathrm{~J})$ & 65.1 & $6.7(\mathrm{~J})$ & $3.0(\mathrm{~J})$ & -- & 14.7 \\
\hline GP-D4 & FTP00035 & 3 & 4 & $4.6(\mathrm{~J})$ & 62.6 & $7.0(\mathrm{~J})$ & $3.3(\mathrm{~J})$ & -- & 11.9 \\
\hline GP-D4 & FTP00036 & 0 & 1 & $3.5(\mathrm{~J})$ & 72.3 & $4.7(\mathrm{~J})$ & $3.5(\mathrm{~J})$ & -- & 16.7 \\
\hline
\end{tabular}


Table A.3-5

Soil Sample Results for Total RCRA Metals and Zinc Detected Above Minimum Reporting Limits, Mercury Fire Training Pit, Nevada Test Site

(Page 2 of 5 )

\begin{tabular}{|c|c|c|c|c|c|c|c|c|c|}
\hline \multirow{2}{*}{$\begin{array}{l}\text { Sample } \\
\text { Location }\end{array}$} & \multirow{2}{*}{$\begin{array}{l}\text { Sample } \\
\text { Number }\end{array}$} & \multirow{2}{*}{$\begin{array}{c}\text { Start } \\
\text { Depth } \\
\text { (ft) }\end{array}$} & \multirow{2}{*}{$\begin{array}{l}\text { End } \\
\text { Depth } \\
\text { (ft) }\end{array}$} & \multicolumn{6}{|c|}{ Contaminant of Potential Concern $(\mathrm{mg} / \mathrm{kg})$} \\
\hline & & & & Arsenic & Barium & Chromium & Lead & Mercury & Zinc \\
\hline \multicolumn{4}{|c|}{ Preliminary Action Levels ${ }^{a}$} & 2.4 & 100,000 & 450 & 1,000 & 510 & 100,000 \\
\hline GP-D3 & FTP00037 & 0 & 1 & $5.3(\mathrm{~J})$ & 99.7 & $11.3(\mathrm{~J})$ & $7.7(\mathrm{~J})$ & -- & 30.6 \\
\hline GP-D3 & FTP00038 & 3 & 4 & $3.9(J)$ & 39.4 & $3.1(\mathrm{~J})$ & $3.1(\mathrm{~J})$ & -- & 5.6 \\
\hline GP-D2 & FTP00039 & 0 & 1 & $5.1(\mathrm{~J})$ & 94.5 & $7.8(\mathrm{~J})$ & $86.4(\mathrm{~J})$ & -- & 89.1 \\
\hline GP-D2 & FTP00040 & 3 & 4 & $4.6(\mathrm{~J})$ & 52.5 & $3.9(\mathrm{~J})$ & $2.5(\mathrm{~J})$ & -- & 12.7 \\
\hline GP-D1 & FTP00041 & 0 & 1 & $3.9(\mathrm{~J})$ & 92.4 & $6.2(\mathrm{~J})$ & $5.5(\mathrm{~J})$ & -- & 22.2 \\
\hline GP-D1 & FTP00042 & 3 & 4 & 4.7 (J) & 48.9 & $3.8(\mathrm{~J})$ & $2.3(\mathrm{~J})$ & -- & 6.3 \\
\hline GP-C2 & FTP00044 & 0 & 1 & 5.6 & 101 & 11.2 & 13.1 & 0.19 & 29.7 \\
\hline GP-C2 & FTP00045 & 3 & 4 & 5.3 & 44.5 & 3.7 & 2.7 & -- & 5.7 \\
\hline GP-C3 & FTP00046 & 0 & 1 & 3.1 & 43.1 & 2.8 & 2.1 & -- & 3.8 \\
\hline GP-C3 & FTP00047 & 3 & 4 & 4.3 & 72.0 & 5.1 & 3.5 & -- & 12.4 \\
\hline GP-C4 & FTP00048 & 0 & 1 & 3.5 & 74.6 & 6.5 & 2.9 & -- & 9.1 \\
\hline GP-C4 & FTP00049 & 3 & 4 & 4.0 & 48.3 & 3.5 & 3.3 & -- & 7.5 \\
\hline GP-C5 & FTP00050 & 0 & 1 & 5.4 & 108 & 10.3 & 7.6 & -- & 31.3 \\
\hline GP-C5 & FTP00051 & 3 & 4 & 3.9 & 59.4 & 4.2 & 2.8 & -- & 8.0 \\
\hline GP-B5 & FTP00053 & 0 & 1 & 3.9 & 58.9 & 4.9 & 4.4 & -- & 10.9 \\
\hline GP-B5 & FTP00054 & 3 & 4 & 7.0 & 53.3 & 4.5 & 2.9 & -- & 8.6 \\
\hline GP-B3b & FTP00055 & 0 & 1 & 3.5 & 60.8 & 6.0 & 5.6 & -- & 4.7 \\
\hline GP-B3b & FTP00056 & 3 & 4 & 4.5 & 52.6 & 5.2 & 2.6 & -- & 7.9 \\
\hline GP-B3a & FTP00057 & 0 & 1 & 3.7 & 54.1 & 4.6 & 4.6 & -- & 70.5 \\
\hline GP-B3a & FTP00058 & 3 & 4 & 4.5 & 52.1 & 3.9 & 3.2 & -- & 6.9 \\
\hline GP-B3a & FTP00059 & 0 & 1 & 2.6 & 42.3 & 4.2 & 7.0 & -- & 145 \\
\hline GP-B2 & FTP00062 & 0 & 1 & 3.4 & 71.2 & 5.6 & 4.4 & -- & 17.0 \\
\hline GP-B2 & FTP00063 & 3 & 4 & 3.4 & 43.6 & 3.2 & 2.1 & -- & 5.1 \\
\hline GP-B1 & FTP00064 & 0 & 1 & 3.8 & 96.7 & 9.3 & 5.1 & -- & 18.6 \\
\hline GP-B1 & FTP00065 & 3 & 4 & 2.8 & 48.9 & 2.6 & 2.2 & -- & 5.7 \\
\hline BP-A1 & FTP00067 & 0 & 1 & 4.7 & 104 & 10.8 & 20.9 & -- & 54.9 \\
\hline GP-A1 & FTP00068 & 3 & 4 & 5.2 & 47.6 & 4.1 & 3.1 & -- & 8.8 \\
\hline GP-A2 & FTP00069 & 0 & 1 & 3.4 & 58.2 & 3.9 & 2.9 & -- & 9.6 \\
\hline
\end{tabular}


Table A.3-5

Soil Sample Results for Total RCRA Metals and Zinc Detected Above Minimum Reporting Limits, Mercury Fire Training Pit, Nevada Test Site (Page 3 of 5 )

\begin{tabular}{|c|c|c|c|c|c|c|c|c|c|}
\hline \multirow{2}{*}{$\begin{array}{l}\text { Sample } \\
\text { Location }\end{array}$} & \multirow{2}{*}{$\begin{array}{l}\text { Sample } \\
\text { Number }\end{array}$} & \multirow{2}{*}{$\begin{array}{l}\text { Start } \\
\text { Depth } \\
\text { (ft) }\end{array}$} & \multirow{2}{*}{$\begin{array}{l}\text { End } \\
\text { Depth } \\
\text { (ft) }\end{array}$} & \multicolumn{6}{|c|}{ Contaminant of Potential Concern $(\mathrm{mg} / \mathrm{kg})$} \\
\hline & & & & Arsenic & Barium & Chromium & Lead & Mercury & Zinc \\
\hline \multicolumn{4}{|c|}{ Preliminary Action Levels ${ }^{a}$} & 2.4 & 100,000 & 450 & 1,000 & 510 & 100,000 \\
\hline GP-A2 & FTP00070 & 3 & 4 & 3.5 & 36.6 & 3.5 & 2.1 & -- & 5.8 \\
\hline GP-A3a & FTP00071 & 0 & 1 & 5.2 & 116 & 12.2 & 52.8 & -- & 119 \\
\hline GP-AЗa & FTP00072 & 3 & 4 & 3.3 & 51.7 & 3.5 & 2.3 & -- & 5.9 \\
\hline GP-A3b & FTP00073 & 0 & 1 & 4.1 & 77.2 & 5.1 & 3.3 & -- & 12.1 \\
\hline GP-A3b & FTP00074 & 3 & 4 & 3.9 & 25.8 & 2.1 & 2.0 & -- & 2.5 \\
\hline GP-A4 & FTP00075 & 0 & 1 & 4.1 & 99.0 & 7.3 & 6.9 & -- & 22.7 \\
\hline GP-A4 & FTP00076 & 3 & 4 & 3.1 & 37.5 & 2.9 & 2.0 & -- & 4.7 \\
\hline GP-A5 & FTP00077 & 0 & 1 & 4.6 & 54.8 & 3.2 & 6.0 & -- & 6.2 \\
\hline GP-A5 & FTP00078 & 3 & 4 & 2.9 & 33.5 & 2.5 & 1.8 & -- & 3.7 \\
\hline SS-A2 & FTP00083 & 0.5 & 1.5 & 4.3 & 61.7 & 4.2 & 25.1 & -- & 88.6 \\
\hline SS-B1 & FTP00084 & 0.5 & 1.5 & 4.0 & 59.1 & 3.6 & 7.6 & 0.45 & 26.1 \\
\hline SS-B1 & FTP00085 & 0.5 & 1.5 & 3.9 & 65.9 & 4.3 & 7.7 & 0.47 & 25.9 \\
\hline SS-B4 & FTP00086 & 0 & 1 & 3.9 & 81.1 & 7.7 & 6.2 & -- & 21.3 \\
\hline B-1 & FTP00089 & 0 & 1 & 2.5 & 43.1 & $2.8(\mathrm{~J})$ & 4.4 & -- & NA \\
\hline B-1 & FTP00091 & 4 & 5 & 3.3 & 30.7 & $1.8(\mathrm{~J})$ & 2.0 & -- & NA \\
\hline B-1 & FTP00094 & 19 & 20 & 5.4 & 44.6 & $4.6(\mathrm{~J})$ & 3.2 & -- & NA \\
\hline B-1 & FTP00094A & 19 & 20 & $--^{c}$ & 46.0 & 4.2 & 5.6(B) & NA & NA \\
\hline B-1 & FTP00095 & 29 & 30 & 5.1 & 46.2 & $3.1(\mathrm{~J})$ & 3.9 & -- & NA \\
\hline B-1 & FTP00096 & 34 & 35 & 4.1 & 52.1 & $2.8(\mathrm{~J})$ & 4.2 & -- & NA \\
\hline B-1 & FTP00097 & 34 & 35 & 4.3 & 47.7 & $2.8(\mathrm{~J})$ & 3.5 & -- & NA \\
\hline B-2 & FTP00099 & 0 & 5 & 3.5 & 80.4 & $4.6(\mathrm{~J})$ & 5.2 & -- & NA \\
\hline B-2 & FTP00100 & 9 & 10 & 4.6 & 32.8 & $2.3(\mathrm{~J})$ & 2.0 & -- & NA \\
\hline B-2 & FTP00101 & 14 & 15 & 3.7 & 31.6 & $2.1(\mathrm{~J})$ & 1.8 & -- & NA \\
\hline B-3 & FTP00103 & 4 & 5 & 3.0 & 40.2 & $2.0(\mathrm{~J})$ & 1.8 & -- & NA \\
\hline B-3 & FTP00104 & 14 & 15 & 5.9 & 45.6 & $2.6(\mathrm{~J})$ & 2.9 & -- & NA \\
\hline B-3 & FTP00105 & 19 & 20 & 4.5 & 42.6 & $2.5(\mathrm{~J})$ & 2.3 & -- & NA \\
\hline B-4 & FTP00107 & 4 & 5 & 3.6 & 60.6 & 2.8 & 2.3 & -- & NA \\
\hline B-4 & FTP00108 & 14 & 15 & 4.8 & 51.3 & 2.8 & 2.6 & -- & NA \\
\hline
\end{tabular}


Table A.3-5

Soil Sample Results for Total RCRA Metals and Zinc Detected Above Minimum Reporting Limits, Mercury Fire Training Pit, Nevada Test Site (Page 4 of 5)

\begin{tabular}{|c|c|c|c|c|c|c|c|c|c|}
\hline \multirow{2}{*}{$\begin{array}{l}\text { Sample } \\
\text { Location }\end{array}$} & \multirow{2}{*}{$\begin{array}{l}\text { Sample } \\
\text { Number }\end{array}$} & \multirow{2}{*}{$\begin{array}{c}\text { Start } \\
\text { Depth } \\
\text { (ft) }\end{array}$} & \multirow{2}{*}{$\begin{array}{l}\text { End } \\
\text { Depth } \\
\text { (ft) }\end{array}$} & \multicolumn{6}{|c|}{ Contaminant of Potential Concern $(\mathrm{mg} / \mathrm{kg})$} \\
\hline & & & & Arsenic & Barium & Chromium & Lead & Mercury & Zinc \\
\hline \multicolumn{4}{|c|}{ Preliminary Action Levels ${ }^{a}$} & 2.4 & 100,000 & 450 & 1,000 & 510 & 100,000 \\
\hline B-4 & FTP00109 & 19 & 20 & 3.1 & 32.6 & 2.0 & 2.2 & -- & $\mathrm{NA}$ \\
\hline B-5 & FTP00111 & 4 & 5 & 3.5 & 40.7 & 2.2 & 2.1 & -- & NA \\
\hline B-5 & FTP00112 & 9 & 10 & 3.7 & 62.1 & 4.4 & 3.2 & -- & NA \\
\hline B-5 & FTP00113 & 24 & 25 & 4.3 & 51.7 & 2.3 & 3.1 & -- & NA \\
\hline B-5 & FTP00114 & 29 & 30 & 3.7 & 47.1 & 2.7 & 3.0 & -- & NA \\
\hline B-6 & FTP00120 & 4 & 5 & 3.4 & 43.5 & 2.4 & 1.8 & -- & NA \\
\hline B-6 & FTP00121 & 14 & 15 & 3.9 & 56.1 & 2.7 & 2.7 & -- & NA \\
\hline B-6 & FTP00122 & 19 & 20 & 3.6 & 32.5 & 2.7 & 1.8 & -- & NA \\
\hline B-7 & FTP00123 & 4 & 5 & 3.2 & 35.6 & 2.6 & 2.4 & -- & NA \\
\hline B-7 & FTP00124 & 14 & 15 & 2.7 & 44.5 & 1.8 & 2.0 & -- & NA \\
\hline B-7 & FTP00125 & 19 & 20 & 3.5 & 35.7 & 2.8 & 2.5 & -- & NA \\
\hline B-8 & FTP00128 & 9 & 10 & 3.5 & 45.2 & 2.2 & 2.7 & -- & NA \\
\hline B-8 & FTP00129 & 34 & 35 & 3.4 & 57.4 & 3.3 & 3.5 & -- & NA \\
\hline B-8 & FTP00130 & 49 & 50 & 3.5 & 43.8 & 3.3 & 3.8 & -- & NA \\
\hline B-8 & FTP00131 & 59 & 60 & 3.7 & 36.2 & 2.3 & 2.6 & -- & NA \\
\hline B-8 & FTP00132 & 69 & 70 & 3.9 & 132 & 3.2 & 3.3 & -- & NA \\
\hline B-9 & FTP00133 & 9 & 10 & 4.9 & 67.3 & 3.1 & 2.4 & -- & NA \\
\hline B-9 & FTP00134 & 19 & 20 & 3.5 & 60.1 & 2.8 & 2.8 & -- & NA \\
\hline B-9 & FTP00135 & 24 & 25 & 4.0 & 48.0 & 3.3 & 3.7 & -- & NA \\
\hline B-10 & FTP00136 & 14 & 15 & 3.3 & 24.0 & 2.4 & 1.4 & -- & NA \\
\hline B-10 & FTP00137 & 29 & 30 & 4.3 & 44.6 & 3.0 & 3.4 & -- & NA \\
\hline B-10 & FTP00138 & 34 & 35 & 3.7 & 43.0 & 2.8 & 2.3 & -- & NA \\
\hline B-10 & FTP00139 & 34 & 35 & 3.9 & 41.7 & 3.1 & 2.3 & -- & NA \\
\hline B-10 & FTP00140 & 39 & 40 & 3.5 & 36.7 & 3.1 & 2.3 & -- & NA \\
\hline B-11 & FTP00145 & 19 & 20 & $3.9(\mathrm{~J})$ & 38.5 & $3.0(\mathrm{~J})$ & $2.9(\mathrm{~J})$ & -- & NA \\
\hline B-11 & FTP00146 & 39 & 40 & $3.9(\mathrm{~J})$ & 41.1 & $3.0(\mathrm{~J})$ & $2.2(\mathrm{~J})$ & -- & NA \\
\hline B-11 & FTP00147 & 44 & 45 & $3.1(\mathrm{~J})$ & 35.6 & $2.7(\mathrm{~J})$ & $2.0(\mathrm{~J})$ & -- & NA \\
\hline B-12 & FTP00149 & 19 & 20 & $3.6(\mathrm{~J})$ & 28.7 & $2.6(\mathrm{~J})$ & $2.8(\mathrm{~J})$ & -- & NA \\
\hline B-12 & FTP00150 & 49 & 50 & $3.1(\mathrm{~J})$ & 35.4 & $3.4(\mathrm{~J})$ & $2.0(\mathrm{~J})$ & -- & NA \\
\hline
\end{tabular}


Table A.3-5

Soil Sample Results for Total RCRA Metals and Zinc Detected Above Minimum Reporting Limits, Mercury Fire Training Pit, Nevada Test Site

(Page 5 of 5 )

\begin{tabular}{|c|c|c|c|c|c|c|c|c|c|}
\hline \multirow{2}{*}{$\begin{array}{l}\text { Sample } \\
\text { Location }\end{array}$} & \multirow{2}{*}{$\begin{array}{l}\text { Sample } \\
\text { Number }\end{array}$} & \multirow{2}{*}{$\begin{array}{c}\text { Start } \\
\text { Depth } \\
\text { (ft) }\end{array}$} & \multirow{2}{*}{$\begin{array}{c}\text { End } \\
\text { Depth } \\
\text { (ft) }\end{array}$} & \multicolumn{6}{|c|}{ Contaminant of Potential Concern $(\mathrm{mg} / \mathrm{kg})$} \\
\hline & & & & Arsenic & Barium & Chromium & Lead & Mercury & Zinc \\
\hline \multicolumn{4}{|c|}{ Preliminary Action Levels ${ }^{a}$} & 2.4 & 100,000 & 450 & 1,000 & 510 & 100,000 \\
\hline $\mathrm{B}-12$ & FTP00151 & 69 & 70 & $4.5(\mathrm{~J})$ & 55.9 & $4.0(\mathrm{~J})$ & $3.6(\mathrm{~J})$ & -- & NA \\
\hline B-13 & FTP00153 & 39 & 40 & 3.8 & 45.9 & 3.1 & 2.2 & -- & NA \\
\hline B-14 & FTP00154 & 24 & 25 & 4.4 & 55.4 & 3.5 & 3.8 & -- & NA \\
\hline B-14 & FTP00155 & 39 & 40 & 3.8 & 33.9 & 4.6 & 2.3 & -- & NA \\
\hline B-14 & FTP00156 & 68 & 69 & 4.4 & 104 & 3.3 & 4.1 & -- & NA \\
\hline B-15 & FTP00157 & 26 & 27 & 3.8 & 39.8 & 2.8 & 2.7 & -- & NA \\
\hline B-16 & FTP00160 & 18.5 & 19 & 2.9 & 25.0 & 1.9 & 1.5 & -- & NA \\
\hline B-16 & FTP00161 & 33 & 34 & 3.4 & 41.1 & 3.2 & 3.2 & -- & NA \\
\hline B-16 & FTP00162 & 54 & 55 & 3.2 & 40.7 & 3.2 & 2.6 & -- & NA \\
\hline B-17 & FTP00163 & 29 & 30 & 4.3 & 38.8 & 3.2 & 3.3 & -- & NA \\
\hline B-17 & FTP00164 & 51.5 & 52.5 & 3.6 & 47.0 & 3.3 & 2.7 & -- & NA \\
\hline
\end{tabular}

aU.S. Environmental Protection Agency Region IX, Industrial PRGs (EPA, 1996a)

${ }^{b}$ Sample FTP00094 was reanalyzed for total RCRA metals by DataChem Laboratories, Inc., as sample FTP00094A

${ }^{\mathrm{C}}$ The method detection limit for arsenic was $6.0 \mathrm{mg} / \mathrm{kg}$ for sample FTP00094A

$\mathrm{J}=$ Estimated value

$B$ = Analyte found in associated blank

$\mathrm{NA}=$ Not analyzed

$--=$ Not detected above minimum reporting limits

cadmium contamination in the totals analysis of samples FTP00089 and FTP00091 and the cadmium contamination is confined to an isolated area of the burn pit; or laboratory anomaly occurred in the TCLP analysis of samples FTP00089 and FTP00091.

\section{A.3.7 Dioxins and Furans Analytical Results}

No dioxins or furans were detected above the minimum reporting limits (DOE/NV, 1998).

\section{A.3.8 Polychlorinated Biphenyls Analytical Results}

No PCBs were detected above the minimum reporting limits (DOE/NV, 1998). 
Table A.3-6

Soil Sample Results for TCLP Metals Detected Above Minimum Reporting Limits, Mercury Fire Training Pit, Nevada Test Site

\begin{tabular}{|c|c|c|c|c|c|c|}
\hline \multirow{2}{*}{$\begin{array}{l}\text { Sample } \\
\text { Location }\end{array}$} & \multirow{2}{*}{ Sample Number ${ }^{a}$} & \multirow{2}{*}{$\begin{array}{c}\text { Start Depth } \\
\text { (ft) }\end{array}$} & \multirow{2}{*}{$\begin{array}{c}\text { End Depth } \\
\text { (ft) }\end{array}$} & \multicolumn{3}{|c|}{ Contaminant of Potential Concern (mg/L) } \\
\hline & & & & Barium & Cadmium & Chromium \\
\hline \multicolumn{4}{|c|}{ Maximum Concentration for the Toxicity Characteristic $^{b}$} & 100.0 & 1.0 & 5.0 \\
\hline GP-B3b & FTP00055A & 0 & 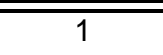 & 0.69 & -- & -- \\
\hline GP-B3a & FTP00057A & 0 & 1 & 0.57 & -- & -- \\
\hline SS-B4 & FTP0086A & 0 & 1 & 0.68 & -- & -- \\
\hline B-1 & FTP00089 & 0 & 1 & $0.5(B)$ & 10.4 & -- \\
\hline B-1 & FTP00091 & 4 & 5 & $0.42(\mathrm{~B})$ & 1.6 & -- \\
\hline B-1 & FTP00094A & 19 & 20 & 0.74 & -- & -- \\
\hline B-5 & FTP00111A & 4 & 5 & 0.5 & -- & -- \\
\hline$B-5$ & FTP00112A & 9 & 10 & 0.73 & -- & -- \\
\hline B-8 & FTP00128A & 9 & 10 & 0.44 & -- & -- \\
\hline B-9 & FTP00133A & 9 & 10 & 0.96 & -- & 0.045 \\
\hline B-14 & FTP00154A & 24 & 25 & 0.47 & -- & -- \\
\hline
\end{tabular}

aThe "A" after a sample number signifies additional analysis not originally requested. These samples were analyzed by DATACHEM Laboratories.

b40 CFR 261.24, "Identification and Listing of Hazardous Waste" (CFR, 1998)

$--=$ Not detected above minimum reporting limits

$\mathrm{B}=$ Analyte found in associated blank

\section{A.3.9 Gamma Spectroscopy Results}

Radionuclides detected above minimum reporting limits (DOE/NV, 1998), along with the associated background concentrations, are presented in Table A.3-7. Radionuclide concentrations in soil samples obtained at the FTP were compared to concentrations in soil samples taken from background locations (Atlan-Tech, 1992; McArthur and Miller, 1989). No man-made radionuclides associated with nuclear testing were detected. Both the concentrations of the detected radionuclides and their distribution support the conclusion that the radionuclides in the FTP soil samples are not distinguishable from soil samples taken from background locations.

One sample (FTP00073) had a detectable result for Potassium-40 $\left({ }^{40} \mathrm{~K}\right)$ greater than the typical background concentration. Potassium-40 is a natural primordial radionuclide. The concentration of ${ }^{40} \mathrm{~K}$ in background locations is highly variable. The baseline and preoperations surface soil samples 
Table A.3-7

\section{Soil Sample Results for Detected Radioactive Isotopes, Mercury Fire Training Pit, Nevada Test Site}

\begin{tabular}{|c|c|c|c|c|c|c|c|c|c|c|}
\hline \multirow{2}{*}{$\begin{array}{l}\text { Sample } \\
\text { Location }\end{array}$} & \multirow{2}{*}{$\begin{array}{l}\text { Sample } \\
\text { Number }\end{array}$} & \multirow{2}{*}{$\begin{array}{c}\text { Start } \\
\text { Depth } \\
\text { (ft) }\end{array}$} & \multirow{2}{*}{$\begin{array}{c}\text { End } \\
\text { Depth } \\
\text { (ft) }\end{array}$} & \multicolumn{7}{|c|}{ Contaminant of Potential Concern $(\mathrm{pCi} / \mathrm{g})$} \\
\hline & & & & Bismuth-214 & Lead-210 & Lead-212 & Lead-214 & Potassium-40 & Thallium-208 & Cesium-137 \\
\hline \multicolumn{4}{|c|}{ Background Concentrations } & $0.21-3.21^{a}$ & $0.21-3.21^{a}$ & $0.18-2.4^{\mathrm{a}}$ & $0.21-3.21^{a}$ & $2.7-34.2^{\mathrm{a}}$ & $0.2-3.4^{\mathrm{b}}$ & $0.04-7.0^{\mathrm{a}}$ \\
\hline GP-F3 & FTP00008 & 0 & 1 & $0.94 \pm 0.29$ & -- & $0.79 \pm 0.20$ & $0.79 \pm 0.20$ & $11.7 \pm 3.1$ & $0.46 \pm 0.14$ & -- \\
\hline GP-F3 & FTP00010 & 0 & 1 & -- & -- & $0.80 \pm 0.18$ & $0.84 \pm 0.19$ & $4.53 \pm 2.91$ & -- & $0.89 \pm 0.19$ \\
\hline GP-E2a & FTP00020 & 0 & 1 & -- & -- & $0.79 \pm 0.23$ & $0.89 \pm 0.24$ & $13.4 \pm 3.68$ & -- & $0.72 \pm 0.19$ \\
\hline GP-E2b & FTP00022 & 0 & 1 & -- & -- & $0.85 \pm 0.19$ & $0.63 \pm 0.18$ & $9.48 \pm 3.36$ & -- & -- \\
\hline GP-E5 & FTP00028 & 0 & 1 & $1.27 \pm 0.36$ & -- & $1.14 \pm 0.22$ & $1.04 \pm 0.25$ & $12.4 \pm 4.3$ & -- & -- \\
\hline GP-D4 & FTP00034 & 0 & 1 & -- & $2.46 \pm 1.11$ & $0.66 \pm 0.19$ & $0.81 \pm 0.22$ & $8.38 \pm 3.23$ & -- & -- \\
\hline GP-D4 & FTP00036 & 0 & 1 & -- & -- & $0.85 \pm 0.21$ & $0.83 \pm 0.21$ & $10.1 \pm 5.6$ & -- & -- \\
\hline GP-D2 & FTP00039 & 0 & 1 & $1.30 \pm 0.34$ & -- & $0.72 \pm 0.24$ & $0.78 \pm 0.21$ & $12.1 \pm 6.8$ & -- & -- \\
\hline GP-C2 & FTP00044 & 0 & 1 & -- & -- & $0.99 \pm 0.2$ & $0.95 \pm 0.21$ & $13.9 \pm 3.48$ & -- & -- \\
\hline GP-C4 & FTP00048 & 0 & 1 & -- & -- & $0.87 \pm 0.22$ & $0.76 \pm 0.24$ & -- & -- & -- \\
\hline GP-B3b & FTP00055 & 0 & 1 & -- & -- & $1.21 \pm 0.3$ & -- & $10.7 \pm 6.1$ & -- & -- \\
\hline GP-B3a & FTP00057 & 0 & 1 & -- & -- & $0.92 \pm 0.29$ & $1.01 \pm 0.3$ & $16.9 \pm 9.2$ & $0.46 \pm 0.18$ & -- \\
\hline GP-B3a & FTP00059 & 0 & 1 & $1.10 \pm 0.29$ & -- & $1.08 \pm 0.23$ & $1.05 \pm 0.21$ & $7.69 \pm 2.97$ & $0.46 \pm 0.13$ & $0.39 \pm 0.17$ \\
\hline GP-B2 & FTP00062 & 0 & 1 & -- & -- & $0.64 \pm 0.16$ & $0.83 \pm 0.19$ & $9.47 \pm 3.14$ & -- & -- \\
\hline GP-B1 & FTP00064 & 0 & 1 & $1.13 \pm 0.31$ & -- & $1.21 \pm 0.25$ & $1.23 \pm 0.27$ & $23.8 \pm 5.6$ & $0.55 \pm 0.15$ & -- \\
\hline GP-A1 & FTP00067 & 0 & 1 & -- & -- & $0.91 \pm 0.26$ & -- & $11.8 \pm 6.9$ & -- & -- \\
\hline GP-A3a & FTP00071 & 0 & 1 & -- & -- & $1.24 \pm 0.29$ & $0.70 \pm 0.27$ & $10.2 \pm 6.09$ & -- & -- \\
\hline GP-A3b & FTP00073 & 0 & 1 & -- & -- & $0.72 \pm 0.24$ & $0.83 \pm 0.24$ & $65.2 \pm 7.4$ & -- & $0.46 \pm 0.23$ \\
\hline B-1 & FTP00089 & $\overline{0}$ & 1 & - & - & $0.34 \pm 0.10$ & -- & -- & - & - \\
\hline
\end{tabular}

${ }^{\mathrm{a}}$ Background concentration listed or derived in Off-Site Radiation Exposure Review Project, Phase // Soils Program (McArthur and Miller, 1989)

${ }^{b}$ Background concentration listed in Environmental Monitoring Report for the Proposed Ward Valley California Low-Level Radioactive Waste (LLRW) Facility (Atlan-Tech, 1992)

Note: All concentrations are assigned "J" (estimated) qualifiers.

$--=$ Not detected above contract required detection limit.

$\mathrm{pCi} / \mathrm{g}=$ Picocuries per gram

taken from Ward Valley, CA had ${ }^{40} \mathrm{~K}$ concentrations ranging from 26 picocuries per gram (pCi/g) to a maximum of $97.7 \mathrm{pCi} / \mathrm{g}$ (Atlan-Tech, 1992). It ranges from 2.7 to $34.2 \mathrm{pCi} / \mathrm{g}$ in surface sample taken from background locations is the states of Nevada, Utah, and Arizona (McArthur and Miller, 1989).

Section 4.2 of the CAIP states that 25 percent of the surface samples will be analyzed using gamma spectroscopy. Eighteen of 34 surface samples were analyzed and one sample from the 0- to 1-ft bgs interval of B-1. Section 4.3.2 of the CAIP states that 25 percent of the drilling samples will be analyzed using gamma spectroscopy (DOE/NV, 1998). Subsurface samples were not analyzed using 
gamma spectroscopy because process knowledge, lack of driving forces, site monitoring did not indicate that radiological contamination should be present in subsurface soil.

It is concluded that no man-made radionuclides have been added to the FTP.

\section{A.3.10 Bioassessment and Geotechnical Results}

Eight bioassessment and seven geotechnical samples were collected (see Table A.2-1 and Table A.2-2 for sample locations). All geotechnical and the majority of the bioassessment samples (samples FTP00093, FTP00105, FTP00111, FTP00118, FTP00148, FTP00158, and FTP00159) were collected in brass sleeves using a California modified split-spoon sampler. In each case, the soil from the uppermost sleeve was transferred to a sample jar, labeled, sealed with custody tape, and submitted to the IT Technology Center for analyses. The remaining two sleeves were capped, labeled, sealed with custody tape, and submitted to Converse Consulting for analysis. Additional bioassessment samples (samples B5-14-15M, B8-14 15M, and B14-29-30M) were collected using the methods described in Section A.2.3.3.

The data were collected to provide input for the evaluation of corrective actions. The findings are summarized in this document, and both data reports are maintained in the contractors files.

\section{A.3.10.1 Bioassessment Results}

A bioassessment was performed on eight soil samples to investigate the feasibility of using bioremediation at the FTP (Appendix E). Bioassessment is a series of tests designed to evaluate the physical, chemical, and microbiological characteristics of a site. The bioassessment consisted of determination of nutrient availability, $\mathrm{pH}$, microbial population density, and the ability of the microbial populations to grow under enhanced conditions. Based on the results of the bioassessment, soil conditions are suitable for bioremediation of contaminated soil at the FTP. The results of the bioassessment are summarized below:

- Viable microbial populations exist at the site and appear to be well adapted to site conditions.

- Heterotrophic populations and hydrocarbon degraders responded favorably to oxygenation but the benefits of oxygentation and nutrient addition were only significant in sample 
B8-14-15M. Nutrient addition to the vadose zone is not recommended until in situ respiration rates decline.

- The optimal $\mathrm{pH}$ for microbial activity is between 6 and 8 . The $\mathrm{pH}$ values for all of the FTP samples were above 8. Although the $\mathrm{pH}$ values fall outside of the typical range for successful biodegradation, microbes adapted to alkaline desert soils appear capable of sustaining aerobic biodegradation.

- Phosphate levels are moderate and ammonia levels are less than the detection limit of $4 \mathrm{mg} / \mathrm{kg}$ for six out of eight of the samples.

- Moisture levels were generally low and may limit biodegradation.

\section{A.3.10.2 Geotechnical Results}

The results of the geotechnical observations suggest that the stratigraphy is dominated by moderate to poorly sorted gravelly sand, with occasional silty gravelly sand. Small lenses of silt and clay are also present, along with isolated caliche layers. See Appendix B for complete soil boring logs. The results of the laboratory analysis of the geotechnical samples are presented in Appendix C. 


\section{A.4.0 Quality Assurance}

The results of the QA/QC activities for the Mercury FTP corrective action investigation sampling events are summarized in the following text. Detailed information regarding the QA program is contained in the Industrial Sites QAPP (DOE/NV, 1996).

Quality control results are typically judged in terms of precision, accuracy, representativeness, completeness, and comparability and are described in the following sections.

\section{A.4.1 Precision}

Precision is a quantitative measure of the variability of a group of measurements from their average value. Precision is assessed for inorganic analysis by collecting and analyzing duplicate field samples and comparing the results with the original sample. Precision is also assessed for inorganic analysis by preparing, analyzing, and comparing laboratory duplicates from one or more field samples. Precisions is assessed for organic analysis by preparing, analyzing, and comparing matrix spike and matrix spike duplicates from one or more field samples. Precision is reported as relative percent difference (RPD) which is calculated as the difference between the measured concentrations of duplicate samples, divided by the average of the two concentrations, and multiplied by 100 .

\section{A.4.2 Accuracy}

Analytical accuracy is defined as the nearness of a measurement to the true or accepted reference value. It is the composite of the random and systematic components of the measurement system and measures bias in the measurement system. The random component of accuracy is measured and documented through the analyses of spiked samples. Sampling accuracy is assessed by evaluating the results of spiked samples and laboratory control samples. Accuracy measurements are calculated as percent recovery by dividing the measured sample concentration by the true concentration and multiplying the quotient by 100 .

Field accuracy is assessed by confirming that the documents of record track the sample from its origin, through transfer of custody, to disposal. The goal of field accuracy is for all samples to be collected from the correct locations at the correct time, placed in correctly labeled containers with the 
correct preservative, and sealed with custody tape to prevent tampering. All samples in this sampling event were properly collected and forwarded to the laboratories as described above.

\section{A.4.3 Representativeness}

Representativeness expresses the degree to which sample data accurately and precisely represent a characteristic of a population, parameter variations at a sampling point, or an environmental condition (EPA, 1987). Sample representativeness was achieved through the implementation of a sampling program designed to ensure proper sampling locations, number of samples, and the use of validated analytical methods. Representativeness was assessed through analysis of duplicate samples. Representativeness of the samples taken in this sampling event was assured by collecting the specified number of samples (DOE/NV, 1998) and by analyzing them by the approved analytical methods shown in Table A.3-1.

\section{A.4.4 Completeness}

Completeness is defined as a percentage of measurements made that are judged to be valid. A sampling and analytical requirement of 80 percent completeness was established for this project (DOE/NV, 1996).

The specified sampling locations were utilized as planned. All samples were collected as specified in the CAIP (DOE/NV, 1998), and all sample containers reached the laboratory intact and properly preserved (when applicable). Sample temperatures were maintained during shipment to the laboratory, and sample chain of custody was maintained during sample storage and/or shipment.

The analyses of the 117 soil samples and 6 duplicates collected from the FTP (CAU 342) were submitted to the laboratories produced 15,340 results. During data evaluation, 50 results were rejected. Thus, a completion level of over 99 percent was achieved.

\section{A.4.5 Comparability}

Comparability is a qualitative parameter expressing the confidence with which one data set can be compared to another (EPA, 1987). To ensure comparability, the FTP field and sampling activities were performed and documented in accordance with approved procedures, and all samples were 
collected in accordance with the CAIP (DOE/NV, 1998), except where noted in Section A.4.8. Approved standardized methods and procedures were also used to analyze and report the data (e.g., Contract Laboratory Program [CLP] and/or CLP-like data packages). This approach ensures that the data from this project can be compared to other data sets. Based on the minimum comparability requirements specified in the Industrial Sites QAPP (DOE/NV, 1996), all requirements were met.

Field (i.e., sample-handling) documentation, laboratory nonconformance reports, and the precision and accuracy of quality-control sample results were evaluated for their effect on the results of the associated environmental soil samples. The environmental sample results were then qualified according to processes outlined in the following sections. Documentation of the data qualifications resulting from these reviews is retained in project files as both hard copy and electronic media.

\section{A.4.6 Tier I and Tier II Data Evaluations}

All laboratory data from samples collected at the FTP have been evaluated for data quality according to the EPA Functional Guidelines (EPA, 1994b and c). These guidelines are implemented in a tiered process and are presented in the following text. No data rejected during the data evaluation process were used to draw the conclusions presented in the CADD. Only valid data, whether estimated (i.e., J-qualified) or not, were used.

The changes resulting from the data evaluation process were documented in project files and were summarized in memoranda for each sample delivery group (SDG). These memoranda are maintained in project files and are available for inspection upon request.

\section{A.4.6.1 Tier I Evaluation}

Tier I evaluation for both chemical and radiological analysis examines (but is not limited to):

- Sample count/type consistent with chain of custody

- Analysis count/type consistent with chain of custody

- Correct sample matrix

- Significant problems stated in cover letter or case narrative

- Completeness of certificates of analysis

- Completeness of CLP or CLP-like packages

- Completeness of signatures, dates, and times on chain of custody 
- Condition-upon-receipt variance form included

- Requested analyses performed on all samples

- Date received/analyzed given for each sample

- Correct concentration units indicated

- Electronic data transfer supplied

- Results reported for field and laboratory QC samples

- Whether or not the deliverable met the overall objectives of the project

\section{A.4.6.2 Tier II Evaluation}

Tier II evaluation for both chemical and radiological analysis examines (but is not limited to):

\section{Chemical:}

- Sample date, preparation date, and analysis date for each sample

- Holding time criteria met

- QC batch association for each sample

- Cooler temperature upon receipt

- Sample $\mathrm{pH}$ for aqueous samples, as required

- Detection limits properly adjusted for dilution, as required

- Blank contamination evaluated and applied to sample results/qualifiers

- $\quad$ MS/MSD percent recoveries (\%R) and RPDs evaluated and applied to laboratory results/qualifiers

- Field duplicate RPDs evaluated using professional judgement and applied to laboratory results/qualifiers

- Laboratory duplicate RPDs evaluated and applied to laboratory results/qualifiers

- Surrogate $\% \mathrm{R}$ evaluated and applied to laboratory results/qualifiers

- Laboratory control sample \%R evaluated and applied to laboratory results/qualifiers

- Initial and continuing calibration evaluated and applied to laboratory results/qualifiers

- Internal standard evaluated and applied to laboratory results/qualifiers

- Recalculation of 10 percent of laboratory results from raw data 


\section{Radioanalytical:}

- Blank contamination evaluated and applied to sample results/qualifiers

- Certificate of Analysis consistent with data package documentation

- QC sample results (duplicates, laboratory control samples) evaluated and applied to laboratory result qualifiers

- Sample results, error, and minimum detectable activity evaluated and applied to laboratory result qualifiers

- Detector system calibrated to National Institute for Standards and Technology (NIST) traceable sources

- Calibration sources preparation documented, demonstrating proper preparation and appropriateness for sample matrix, emission energies, and concentrations

- Detector system response to daily, weekly, and monthly background and calibration checks for peak energy, peak centroid, peak full-width half-maximum, and peak efficiency

- NIST-traceable tracers, appropriate for the analysis performed, and recoveries that met QC requirements

- Documentation of all QC sample preparation complete and properly performed

- Spectra lines, emissions, particle energies, peak areas, and background peak areas support the identified radionuclide and its concentration

- QC sample results (e.g., calibration source concentration, percent recovery, and RPD) verified

- Radionuclides and their concentration appropriate considering their decay schemes, half-lives, and process knowledge and history of the facility and site

- Each identified line in spectra verified against emission libraries and calibration results

\section{A.4.6.3 Tier III Evaluation}

Data quality considerations that are included in EPA data review functional guidelines (EPA, 1994b and c) as a Tier III review include, but are not limited to, the additional evaluations:

\section{Chemical:}

- Mass spectrometer tuning criteria

- Initial and continuing calibration verification 
- Internal standard evaluation

- Organic compound quantitation

- Inductively coupled plasma (ICP) interference check sample evaluation

- Graphite furnace atomic absorption quality control

- ICP serial dilution effects

- Recalculation of all laboratory results from raw data

\section{Radioanalytical:}

- QC sample results (e.g., calibration source concentration, percent recovery, and RPD) verified

- Radionuclides and their concentration appropriate considering their decay schemes, half-lives, and process knowledge and history of the facility and site

- Each identified line in spectra verified against emission libraries and calibration results

- Independent identification of spectra lines, area under the peaks, and quantification of radionuclide concentration in a random number of sample results

Tier III review of at least five percent of the sample analytical data was performed by Lockheed-Martin Environmental Services in Las Vegas, Nevada. Changes to the data resulting from this review have been documented in project files.

\section{A.4.7 Quality Control Samples}

Twenty-two trip blanks, six field blanks, six equipment rinsate blanks, six MS/MSDS, and six field duplicates were collected and submitted for laboratory analysis as shown in Tables A.2-1 and A.2-2. The samples and duplicates were assigned individual sample numbers and sent to the laboratory "blind." Additional samples were selected by the laboratory to be analyzed as laboratory duplicates. The field blanks were taken by placing distilled water into appropriate sample bottles and preserving them according to the requirements specified in the Industrial Sites QAPP (DOE/NV, 1996). The equipment rinsate blanks were obtained by collecting the final rinse solution (i.e., distilled water), which was poured over the decontaminated sampling equipment into the appropriate sample bottles and preserved as applicable. The trip blanks, which were received sealed and preserved from the laboratory, were placed in each cooler containing samples for VOC analysis. The results of the QC samples are discussed in the following sections. 


\section{A.4.7.1 Field Quality Control Samples}

Review of the field-collected blank analytical data for the investigation sampling indicates that cross-contamination from field methods did not occur during sample collection. Field and equipment rinsate blanks were analyzed for the parameters listed in Tables A.2-1 and A.2-2, and trip blanks were analyzed for VOCs only. None of the results for these field-collected blanks exceeded the minimum laboratory reporting limits (DOE/NV, 1998).

During the sampling event, six field duplicate soil samples were sent as blind samples to the laboratory to be analyzed for the investigation parameters listed in Tables A.2-1 and A.2-2. For these samples, the duplicate results precision (i.e., RPDs between the environmental sample results and their corresponding field duplicate sample results) were evaluated against the guidelines set forth in EPA Functional Guidelines (EPA, 1994b and c). The EPA Functional Guidelines state that there are no required review criteria for field duplicate analyses comparability, but allow the data reviewer to exercise professional judgement. The RPD between the environmental sample results and their corresponding field duplicate sample results exceeded the 20 percent criteria stated in the Industrial Sites QAPP (DOE/NV, 1996) for some target analytes (acetone, chromium, lead, and zinc). The variability in the results between the environmental samples and their corresponding field duplicate samples could be attributed to nonhomogeneous samples and the difficulties associated with collecting identical field samples. It is expected that soil field duplicate results will have a greater variance than water matrices.

The laboratory duplicate samples were compared to the criteria set forth in the EPA Functional Guidelines (EPA, 1994c) and the associated sample results were qualified accordingly. Both detections and nondetections have been qualified as estimated ( $\mathrm{J}$ and $\mathrm{UJ}$, respectively) if the relative percent difference between an environmental sample and its laboratory field duplicate fell outside established criteria.

Six field samples were selected for use as MS/MSD samples. The percent recoveries of these samples (a measure of accuracy) and the relative percent differences in these sample results (a measure of precision) were compared to EPA Functional Guideline criteria (EPA, 1994b and c). The results were used to qualify associated environmental sample results accordingly. 
The EPA Functional Guidelines for review of organic data state that no data qualification action is taken on the basis of MS/MSD results alone. The data reviewer exercises professional judgement in considering these results in conjunction with the results of laboratory control samples (LCSs) and other QC criteria in applying qualifications to the data.

The inorganic data review in EPA Functional Guidelines allows professional judgement to be applied in evaluating the results of both matrix spikes. Generally, if the spike recovery is greater than the upper acceptance limits, nondetections are not qualified. If the spike recovery is greater than the upper acceptance limits or less than the lower acceptance limit, positive results are qualified as estimated (J) and nondetections are qualified as estimated (UJ), respectively. If the spike recovery is less than 30 percent (grossly low), positive results are not qualified and nondetections are qualified unusable $(\mathrm{R})$.

\section{A.4.7.2 Laboratory Quality Control Samples}

Analysis of method QC blanks and surrogate spikes for organic analyses, method blanks, preparation blanks, initial and continuing calibration blanks for total metals and TCLP metals, and LCS were performed for each SDG by Quanterra Environmental Services laboratory. The results of these analyses were used to qualify associated environmental sample results according to EPA Functional Guidelines (EPA, 1994b and c).

The EPA Functional Guidelines (EPA, 1994b and c) state that no qualification action is taken if a compound is found in an associated blank, but not in the sample or if a compound is found in the sample, but not in an associated blank. The action taken when a compound is detected in both the sample and the associated blank varies depending upon the analyte involved and is described in the “The 5X/10X Rule."

For most VOCs and SVOCs, if an analyte is detected in the sample and was also detected in an associated blank the result is qualified as undetected (U) if the sample concentration is less than five times $(5 \mathrm{X})$ the blank concentration.

For the common laboratory contaminants (e.g., methylene chloride, acetone, MEK, and phthalate esters [especially bis(2-ethylhexyl)phthalate]), the factor is raised to ten times (10X) the blank 
concentration. The sample result is elevated to the quantitation limit if it is less than the quantitation limit or remains unaltered if the sample result is greater than or equal to the quantitation limit.

For inorganics (i.e., metals), sample results greater than the instrument detection limit, but less than five times $(5 \mathrm{X})$ the amount found in an associated blank, are qualified as undetected $(\mathrm{U})$. There are no metallic common laboratory contaminants, so there is no "10X Rule" for metals, and the sample result is never altered. When applying the $5 \mathrm{X}$ criteria to soil sample data or calibration blank data, the raw data results are used to evaluate and qualify the reported results on the Certificates of Analysis.

Surrogate spikes, or system monitoring compounds, are added to the environmental samples analyzed by chromatographic techniques for VOCs, SVOCs, gasoline, and diesel. Surrogate compounds are analytes that are not expected to be present in associated environmental samples, but behave the same as similar target compounds chromatographically. Known amounts of each surrogate are added prior to sample preparation and are carried throughout the preparation/analysis procedure. The percent recoveries of these surrogate compounds give some measure of the anticipated recoveries of the target compounds whose chromatographic behavior they mimic.

If any surrogate percent recoveries are out of the acceptable range (which differs for each surrogate in each method), laboratory protocol calls for the sample to be reprepared and/or reanalyzed. When the surrogate recoveries are acceptable on the second run, only the second analysis results are reported. When both analyses yield the same unacceptable range, the results of both analyses are reported.

The evaluation of surrogate spike percent recovery results is not straightforward. The functional guidelines suggest several optional approaches, but require the data reviewer to exercise professional judgement in reviewing surrogate data and qualifying associated data as estimated ( $\mathrm{J}$ or $\mathrm{UJ}$, for detections or nondetections, respectively) or unusable (R). Documentation of data qualifications resulting from the application of these guidelines is retained in the project files as both hard copy and electronic media.

One laboratory duplicate analysis for metals was performed for each SDG. The duplicate results are compared to the results of the original sample to give a measure of analytical laboratory precision. If the results from a duplicate analysis for a particular analyte fall outside the control limits, the EPA Functional Guidelines for Inorganic Data Review (EPA, 1994c) call for all results for that analyte in 
all associated samples of the same matrix to be qualified as estimated (J). Documentation of data qualifications resulting from the application of these guidelines is retained in the project files as both hard copy and electronic media.

Laboratory control samples, also known as blank spikes, consist of known quantities of target compounds added to purified sand or deionized, distilled water and analyzed along with the environmental samples in the sample delivery group. The percent recoveries of the compounds in the LCS give a measure of laboratory accuracy. The functional guidelines call for the data reviewer to use professional judgement to qualify associated data according to established criteria.

Documentation of data qualifications resulting from the application of these guidelines is retained in project files as both hard copy and electronic media.

\section{A.4.8 Field Nonconformances}

During the corrective action investigation, one QA surveillance was conducted by IT Corporation to verify that sampling activities were performed in accordance with applicable requirements. The results of the surveillance indicated no findings, deficiencies, or nonconformances with sampling activities as they met the requirements of the plans and procedures governing the activities at the site. Documentation of these results is retained in project files.

\section{A.4.9 Laboratory Nonconformances}

Laboratory nonconformances are generally due to inconsistencies in analytical instrumentation operation, sample preparations, extractions, and fluctuations in internal standard and calibration results. Several laboratory nonconformances were documented for this project. These nonconformances have been accounted for in the data qualification process. Data were rejected as a result of these nonconformances. One additional sample was collected for PCB analysis to compensate for rejected data. Documentation of these results is retained in project files. 


\section{A.5.0 Summary}

Analysis of the data generated from corrective action investigation activities conducted at the FTP indicates the following:

- A subsurface plume or plumes of TPH greater than $100 \mathrm{mg} / \mathrm{kg} \mathrm{TPH}$ is associated with the AST area. The combined lateral extent does not exceed approximately 130 by $80 \mathrm{ft}$. The plume(s) originated from at least three surface sources (ASTs which have been removed) and extends vertically to an approximate depth of $50 \mathrm{ft}$ bgs.

- A subsurface plume of TPH greater than $100 \mathrm{mg} / \mathrm{kg}$ TPH is associated with the burn pit. The plume has approximate lateral dimensions of 65 by $27 \mathrm{ft}$. The plume originates from excess fuel not burned in the burn pit and has an approximate depth of $30 \mathrm{ft}$ bgs.

- Surface contamination is evident in contiguous areas downgradient from both the AST area and burn pit. Total surface contamination includes $16,300 \mathrm{ft}^{2}$ and $5,830 \mathrm{ft}^{2}$ areas and three areas with much less vertical and lateral extent. This surface contamination is believed to have originated from runoff from surface contamination in both the AST area and burn pit. The depth of this contamination is not well defined.

- Surface contamination was evident at the telephone poles, one burn shed (southernmost), and the bus.

- Arsenic concentrations were above the PAL of $2.4 \mathrm{mg} / \mathrm{kg}$ and ranged from $2.5 \mathrm{mg} / \mathrm{kg}$ to $5.9 \mathrm{mg} / \mathrm{kg}$ with two exceptions, samples FTP00021 and FTP00054 had the highest arsenic concentrations of $10.8 \mathrm{mg} / \mathrm{kg}$ and $7.0 \mathrm{mg} / \mathrm{kg}$ respectively. These arsenic concentrations are not unusual for the State of Nevada and represent naturally occurring (background) concentrations.

- Xylene was detected above the PAL in one sample collected from the area of highest TPH contamination in the AST subsurface plume.

- No other chemical constituents were detected above the PALs.

- Other VOCs and SVOCs detected appear to be associated with the areas of TPH contamination.

- Radiological analytical results were not distinguishable from background concentrations (PALs) (DOE/NV, 1998). 


\section{A.6.0 References}

ASTM, see American Society for Testing and Materials.

American Society for Testing and Materials. 1996. Section 04.08 and 04.09, "Construction." In Annual Book of ASTM Standards. Philadelphia, PA.

Atlan-Tech, Inc. 1992. Environmental Monitoring Report for the Proposed Ward Valley California Low-Level Radioactive Waste (LLRW) Facility. Rosewell, GA.

CFR, see Code of Federal Regulations.

Code of Federal Regulations. 1998. Title 40 CFR Parts 260 - 282, "RCRA Regulations."

Washington, DC: U.S. Government Printing Office.

DOE, see U.S. Department of Energy.

DOE/NV, see U.S. Department of Energy, Nevada Operations Office.

EG\&G Energy Measurements. 1994. Aerial photograph number 7895-6. Nellis Air Force Base, NV: Remote Sensing Laboratory Photo Library.

EPA, see U.S. Environmental Protection Agency.

FFACO, see Federal Facility Agreement and Consent Order.

Federal Facility Agreement and Consent Order. 1996 (as amended). Agreed to by the State of Nevada, the U.S. Department of Energy, and the U.S. Department of Defense.

IT, see IT Corporation.

IT Corporation. 1998a. Bioassessment Report, Nevada Test Site, CAU 342, Area 23 Mercury Fire Training Pit. Knoxville, TN.

IT Corporation. 1998b. Site-Specific Health and Safety Plan, Mercury Fire Training Pit, Nevada Test Site. Las Vegas, NV.

McArthur, R.D., and F.L. Miller, Jr. 1989. Off-Site Radiation Exposure Review Project (ORERP), Phase II Soil Program, DOE/NV/10384-23, Publication No. 45064. Las Vegas, NV:

Desert Research Institute.

NAC, see Nevada Administrative Code. 
Nevada Administrative Code. 1996. NAC 445A.227, "Contamination of soil: Order by director of corrective action; factors to be considered in determining whether corrective action is required." Carson City, NV.

Robie, L., S. Reiner, and G. Locke. 1995. Ground-water Data for the Nevada Test Site, 1992, and for Selected Other Areas in South-Central Nevada, 1952-92, USGS OFR-95-284. Denver, CO: U.S. Geological Survey.

Shacklette, H.T., and J.G. Boerngen. 1984. Element Concentrations in Soils and Other Surficial Materials of the Conterminous United States, U.S. Geological Survey Professional Paper 1270. Washington, DC: U.S. Government Printing Office.

USACE, see U.S. Army Corps of Engineers.

U.S. Army Corps of Engineers. 1970. "Laboratory Soils Testing.” In Engineering Manual 1110-2-1906, Appendix II. Washington, DC.

U.S. Department of Energy. 1992. Environmental Measurements Laboratory Procedures Manual, HASL-300, 27th Edition, Vol. 1. New York, NY.

U.S. Department of Energy, Nevada Operations Office. 1996. Industrial Sites Quality Assurance Project Plan, Nevada Test Site, Nevada, Rev. 1, DOE/NV--372. Las Vegas, NV.

U.S. Department of Energy, Nevada Operations Office. 1998. Corrective Action Investigation Plan for CAU 342: Area 23 Mercury Fire Training Pit Nevada Test Site, Nevada, DOE/NV--498, UC-700. Las Vegas, NV: IT Corporation.

U.S. Environmental Protection Agency. 1987. Data Quality Objectives for Remedial Response Activities, EPA/540/G-87-003. Washington, DC.

U.S. Environmental Protection Agency. 1994a. Guidance for the Data Quality Objectives Process, EPA QA/G-4. Washington, DC.

U.S. Environmental Protection Agency. 1994b. Contract Laboratory Program National Functional Guidelines for Organic Data Review, EPA 540/R-94/012. Washington, DC.

U.S. Environmental Protection Agency. 1994c. Contract Laboratory Program National Functional Guidelines for Inorganic Data Review, EPA 540/R-94/013. Washington, DC.

U.S. Environmental Protection Agency. 1996a. Memo from S.J. Smucker to PRG Table Mailing List regarding Region IX Preliminary Remediation Goals (PRGs), 1 August. San Francisco, CA.

U.S. Environmental Protection Agency. 1996b. Test Methods for Evaluating Solid Waste, Physical/Chemical Methods, SW-846, CD ROM which contains updates for 1986, 1992, 1994, and 1996. Washington, DC. 
USGS, see U.S. Geological Survey.

U.S. Geological Survey. 1983a. "Camp Desert Rock Quadrangle, Nevada-Nye County," 7.5 Minute Series, Topographic Map.

U.S. Geological Survey. 1983b. "Mercury Quadrangle, Nevada-Nye County," 7.5 Minute Series, Topographic Map.

Winograd, I.J., and W. Thordarson. 1975. Hydrogeologic and Hydrochemical Framework, Southcentral Great Basin, Nevada-California, with Special Reference to the Nevada Test Site, U.S. Geological Survey Professional Paper 712C. Washington, DC: U.S. Government Printing Office. 


\section{Appendix B}

Soil Boring Logs 


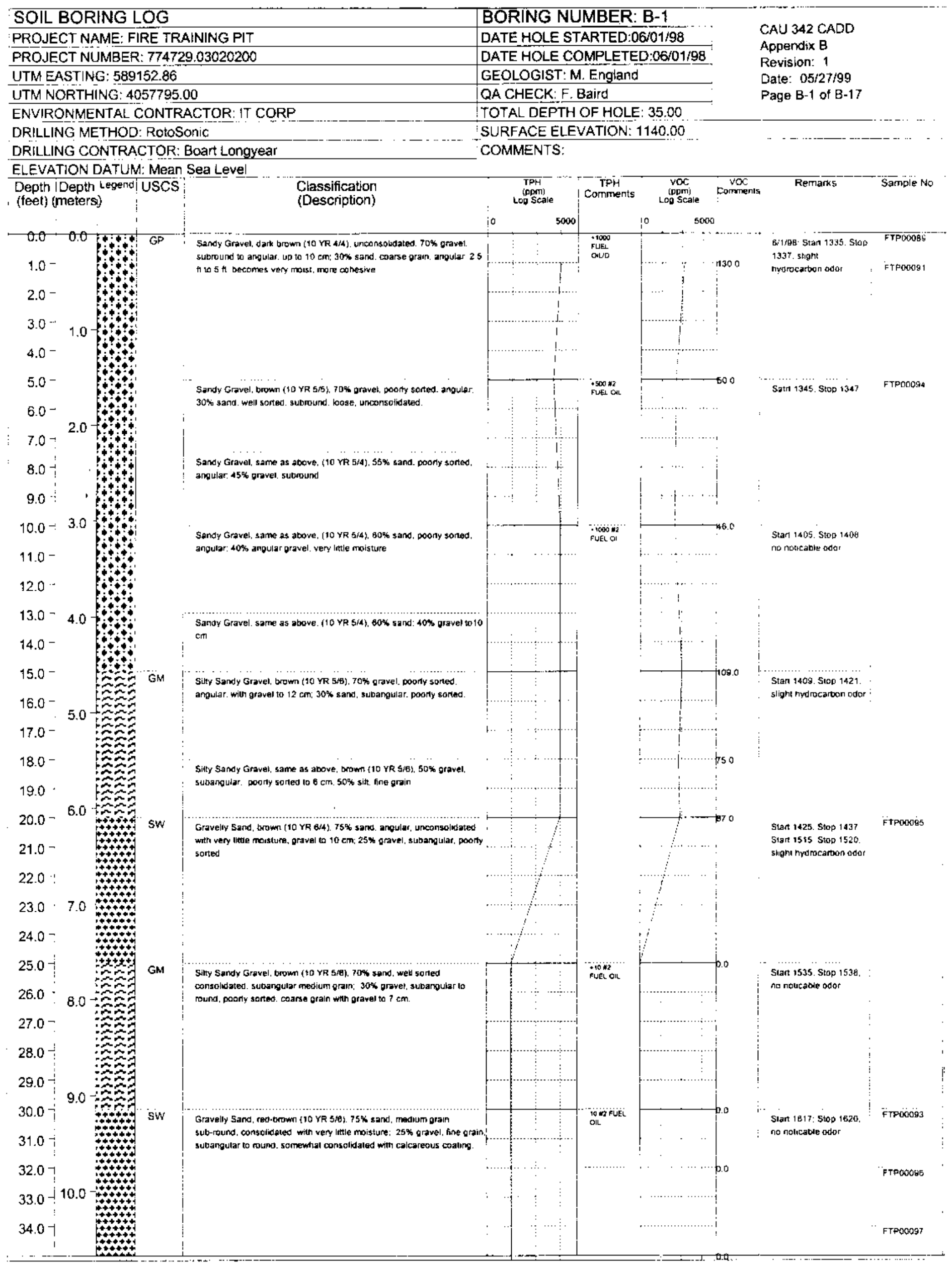




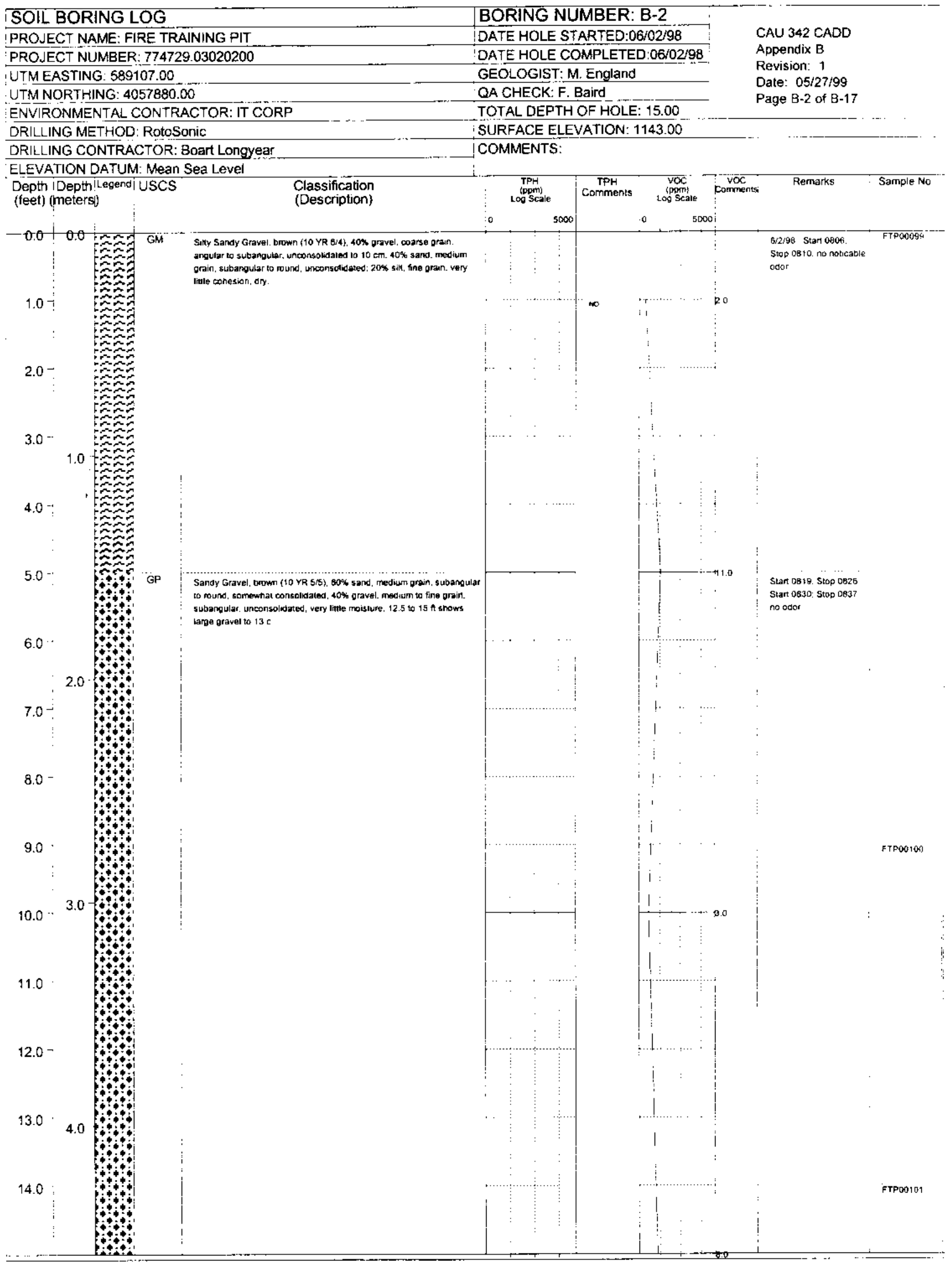




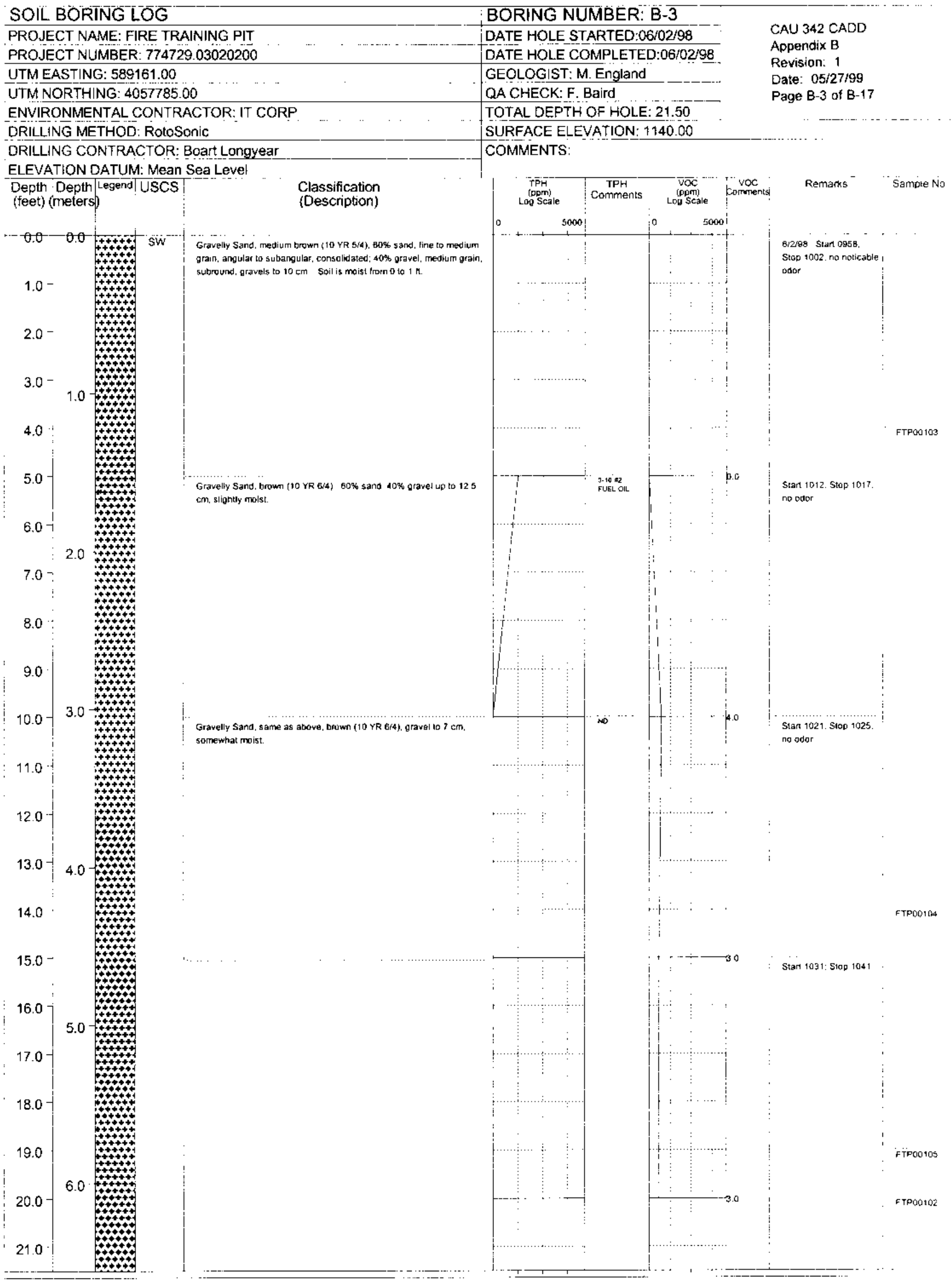




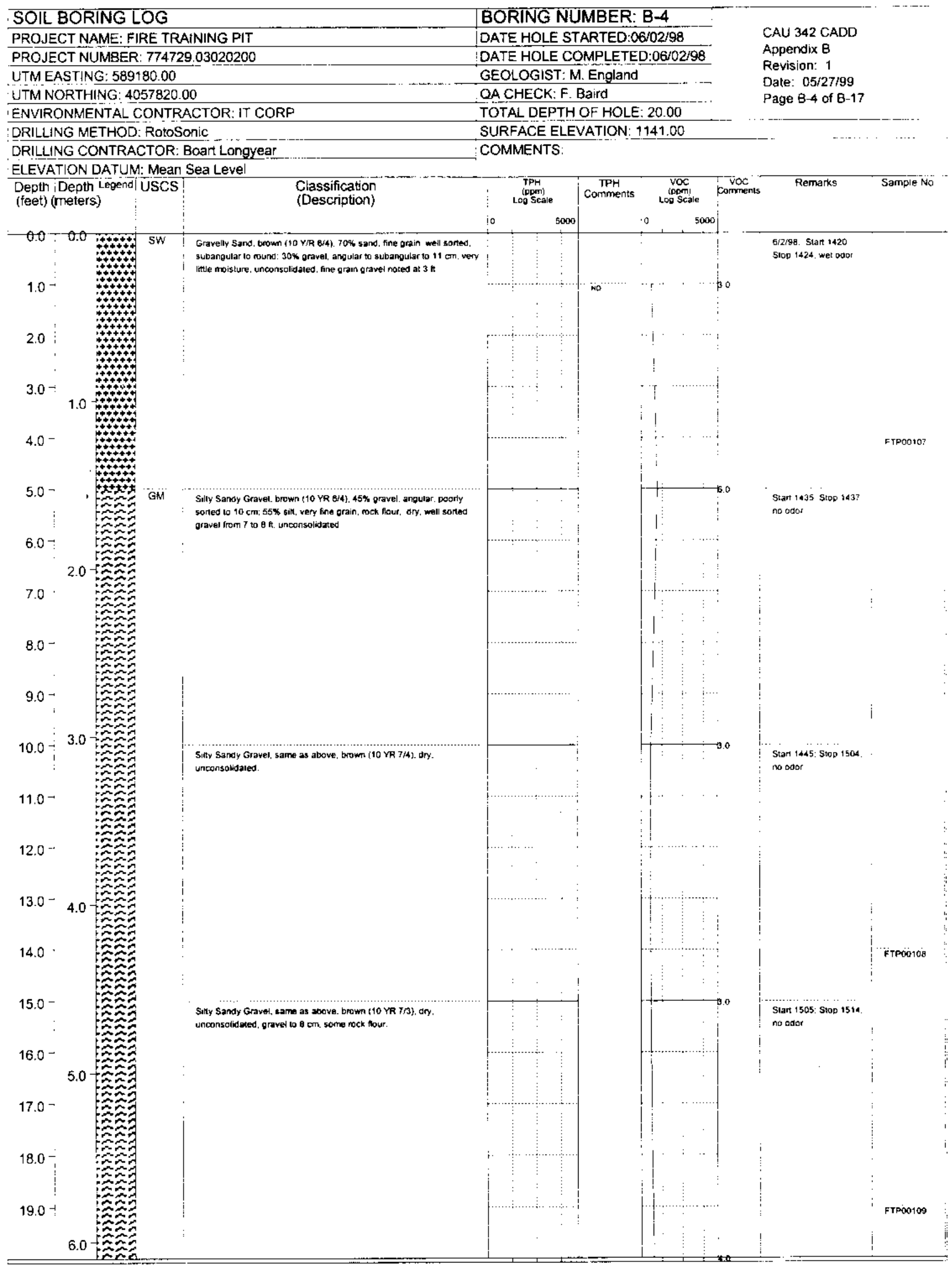




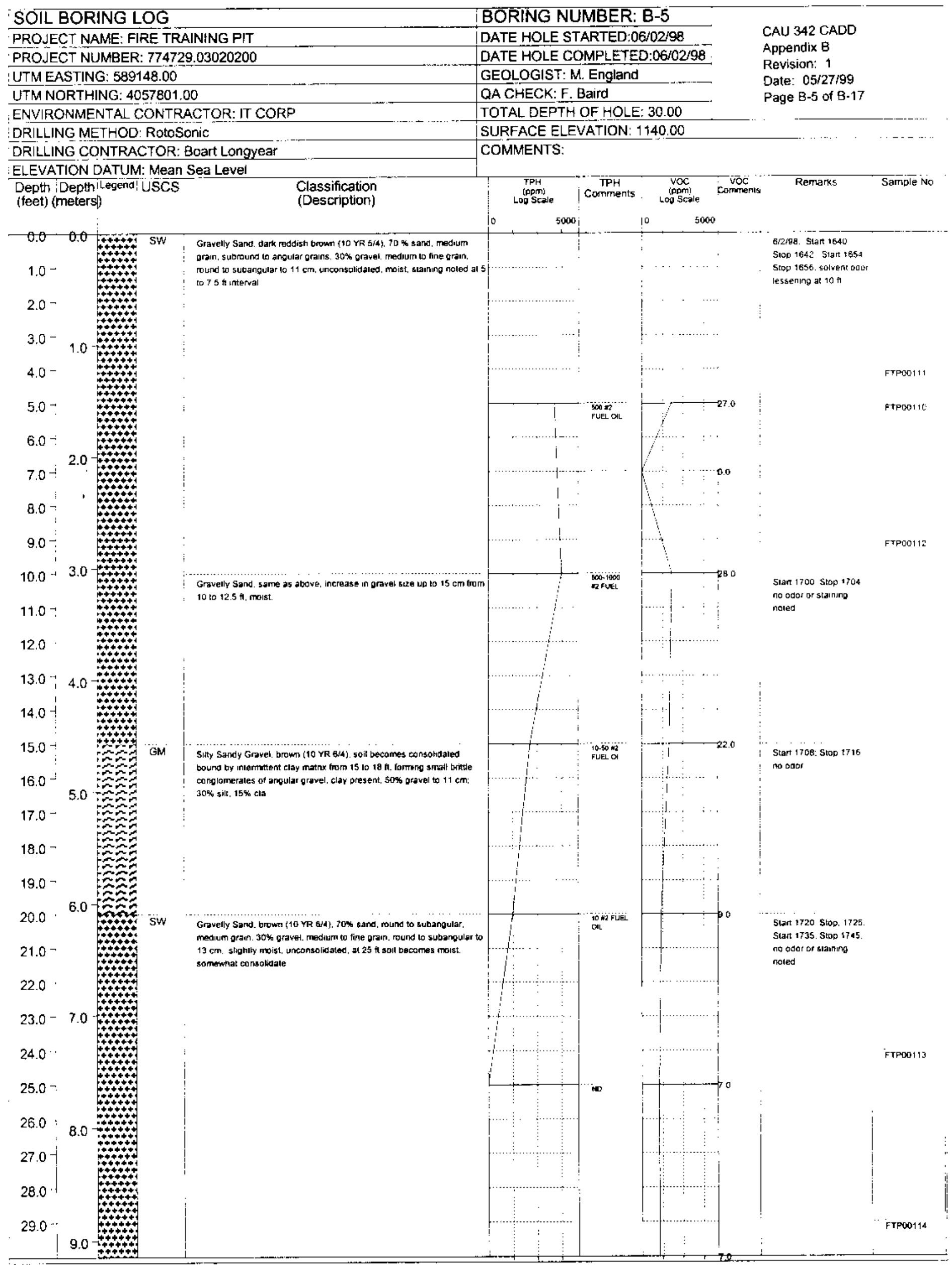




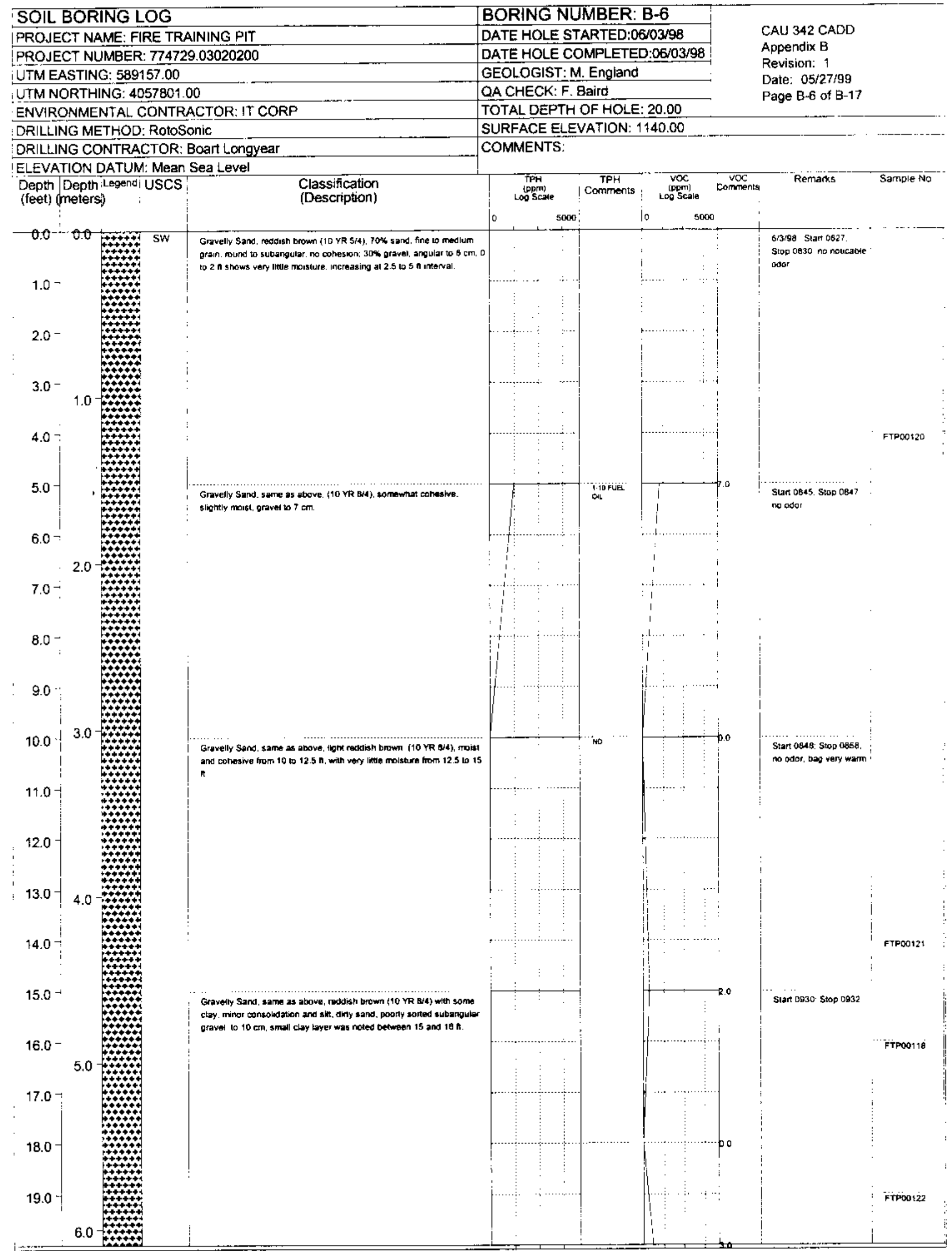




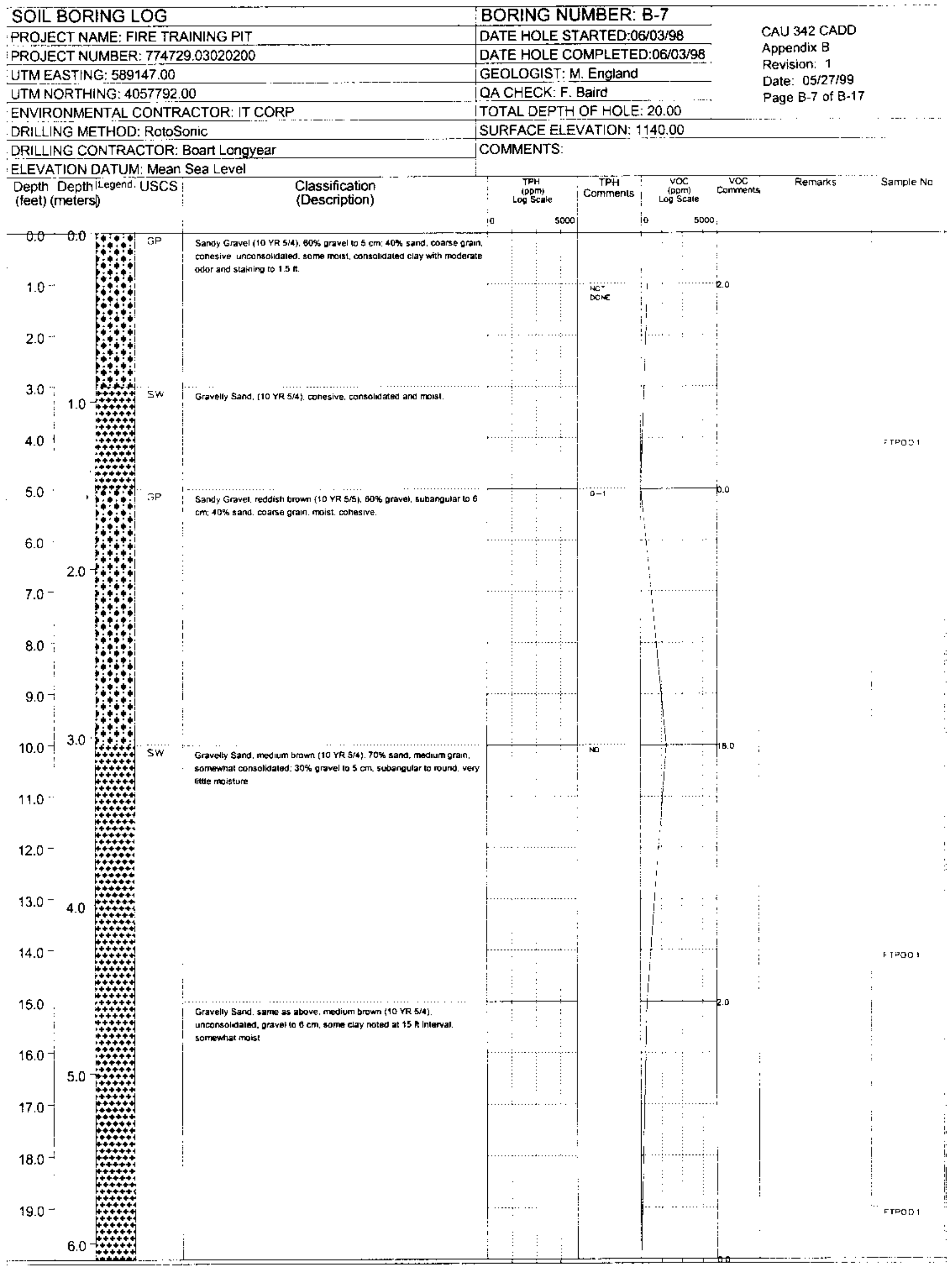




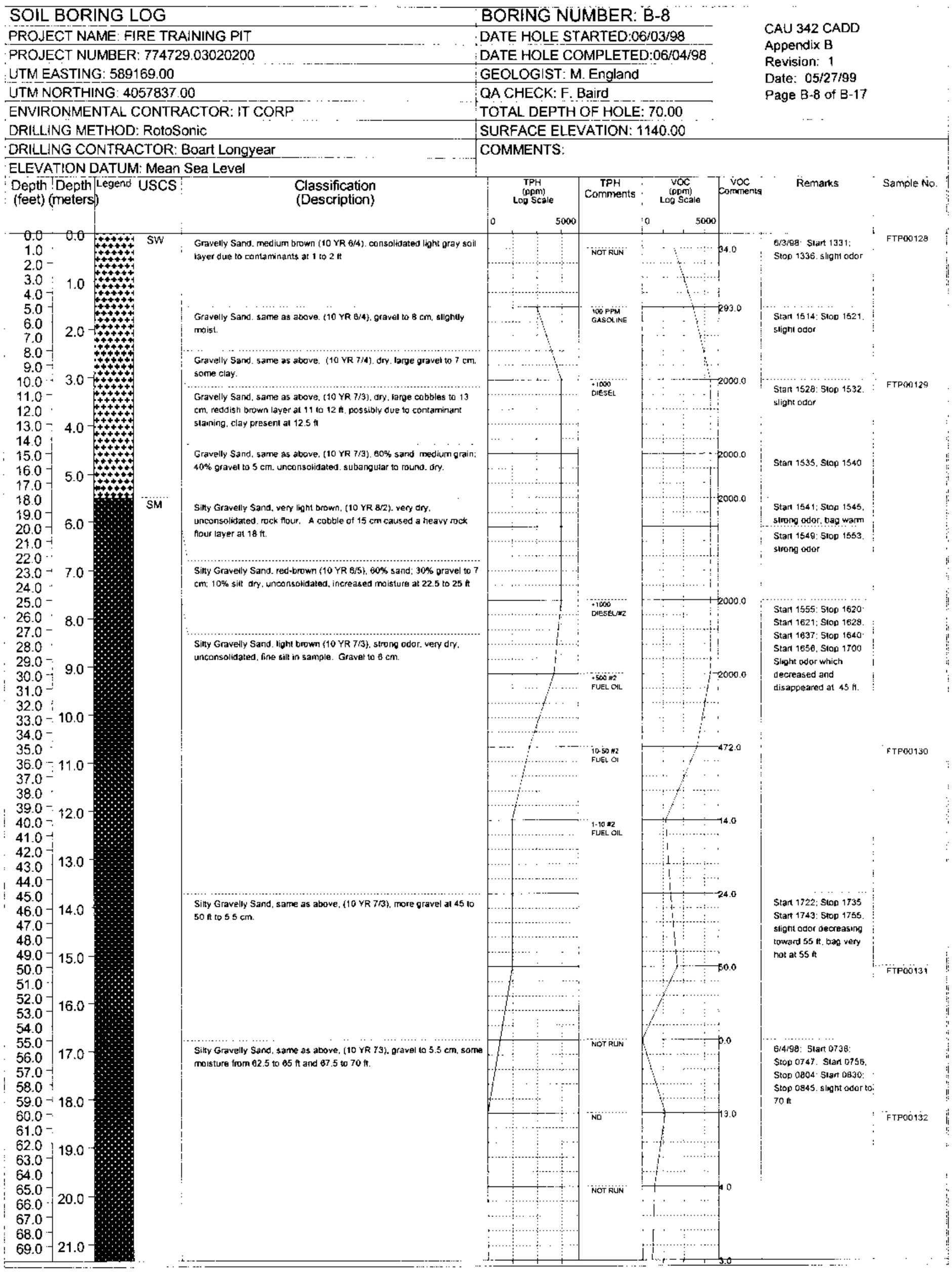




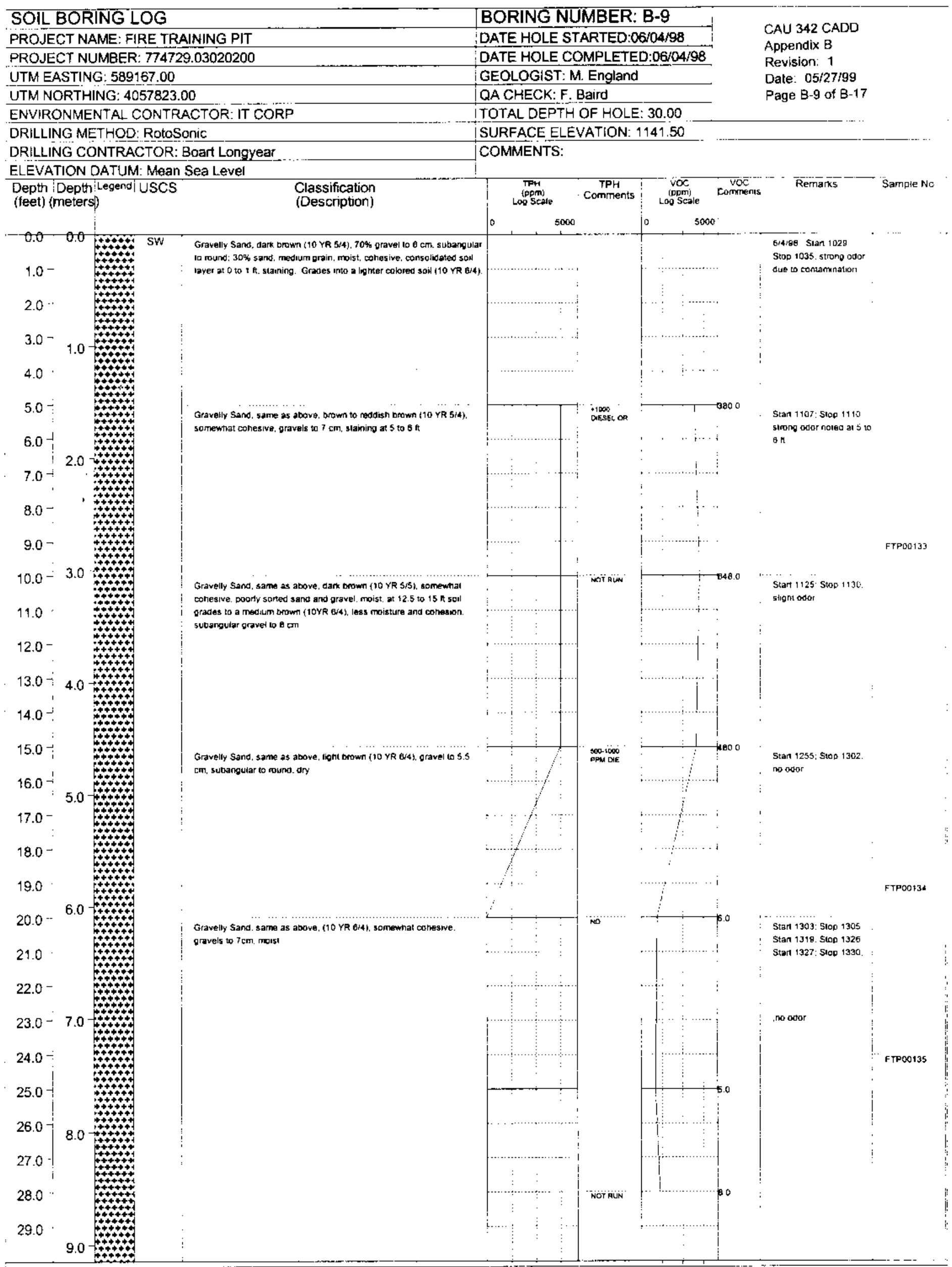




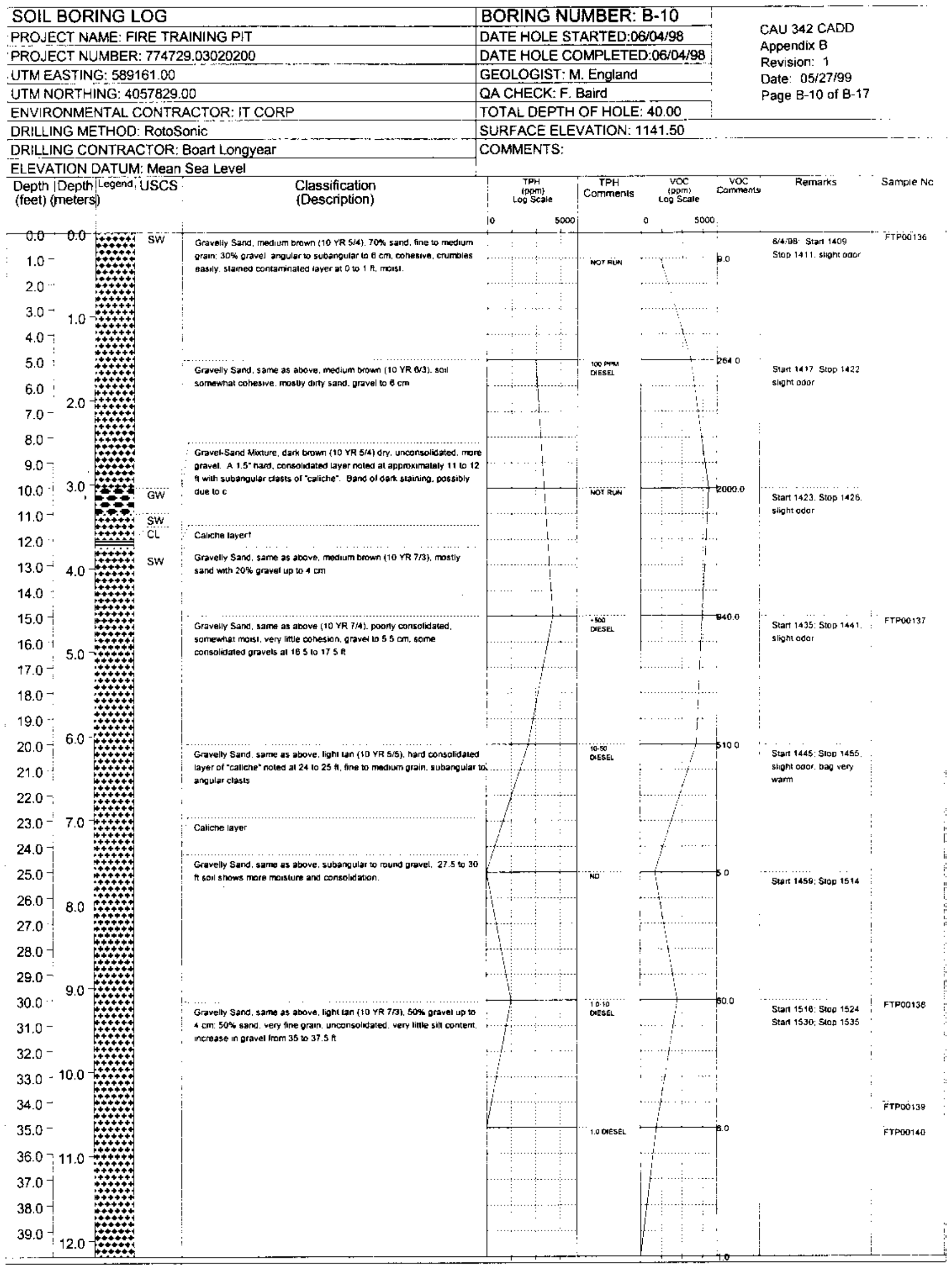




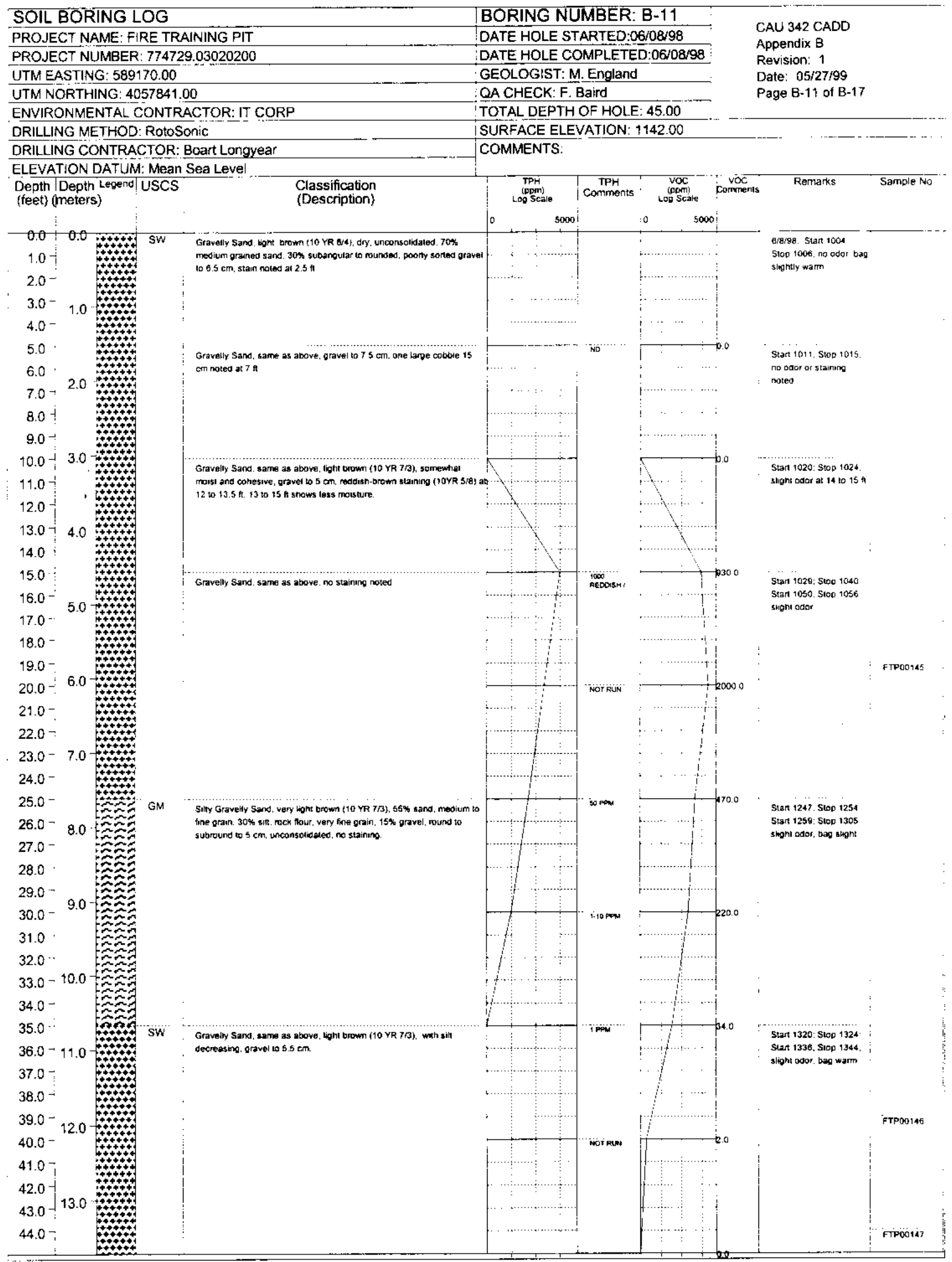




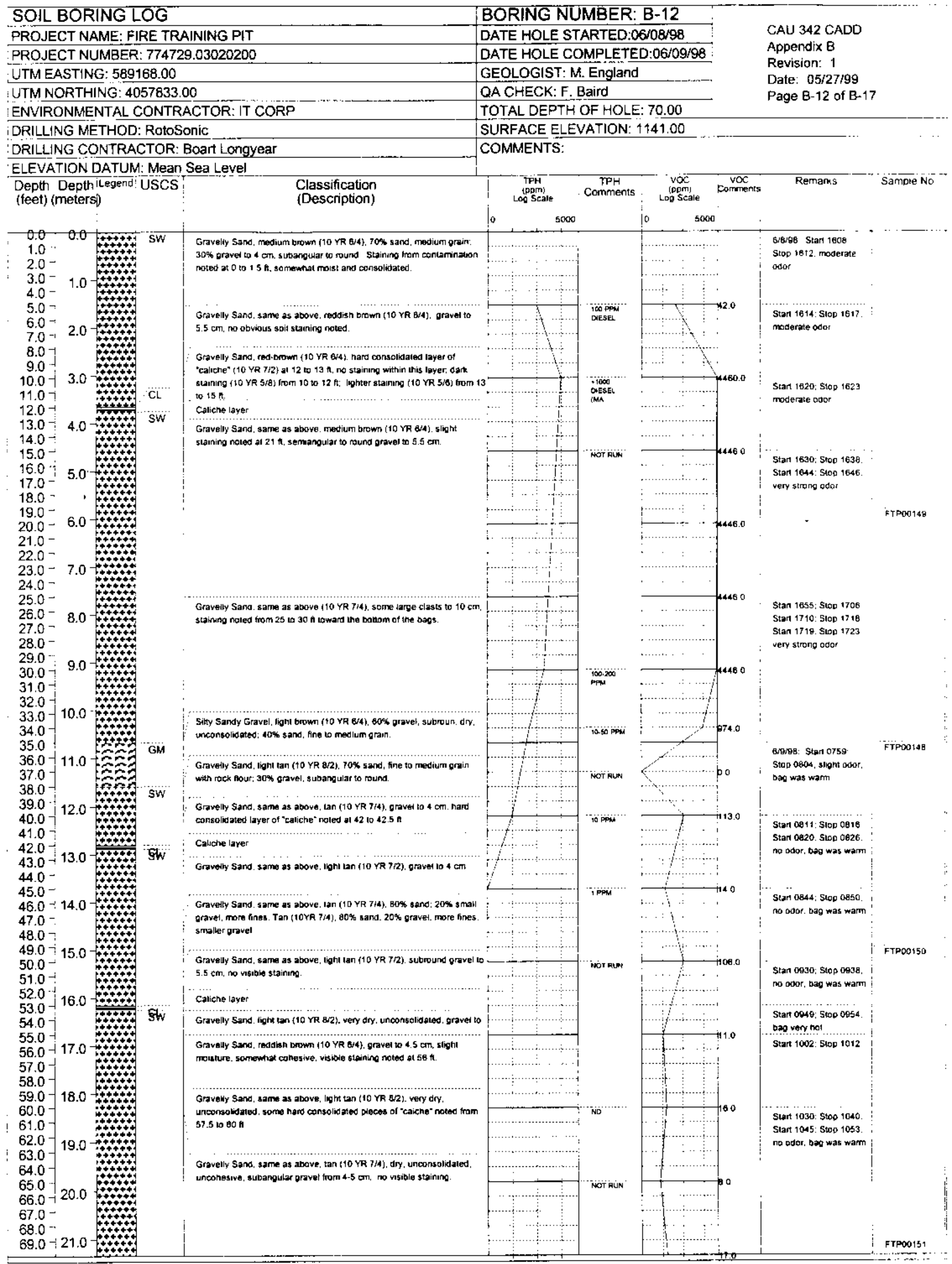




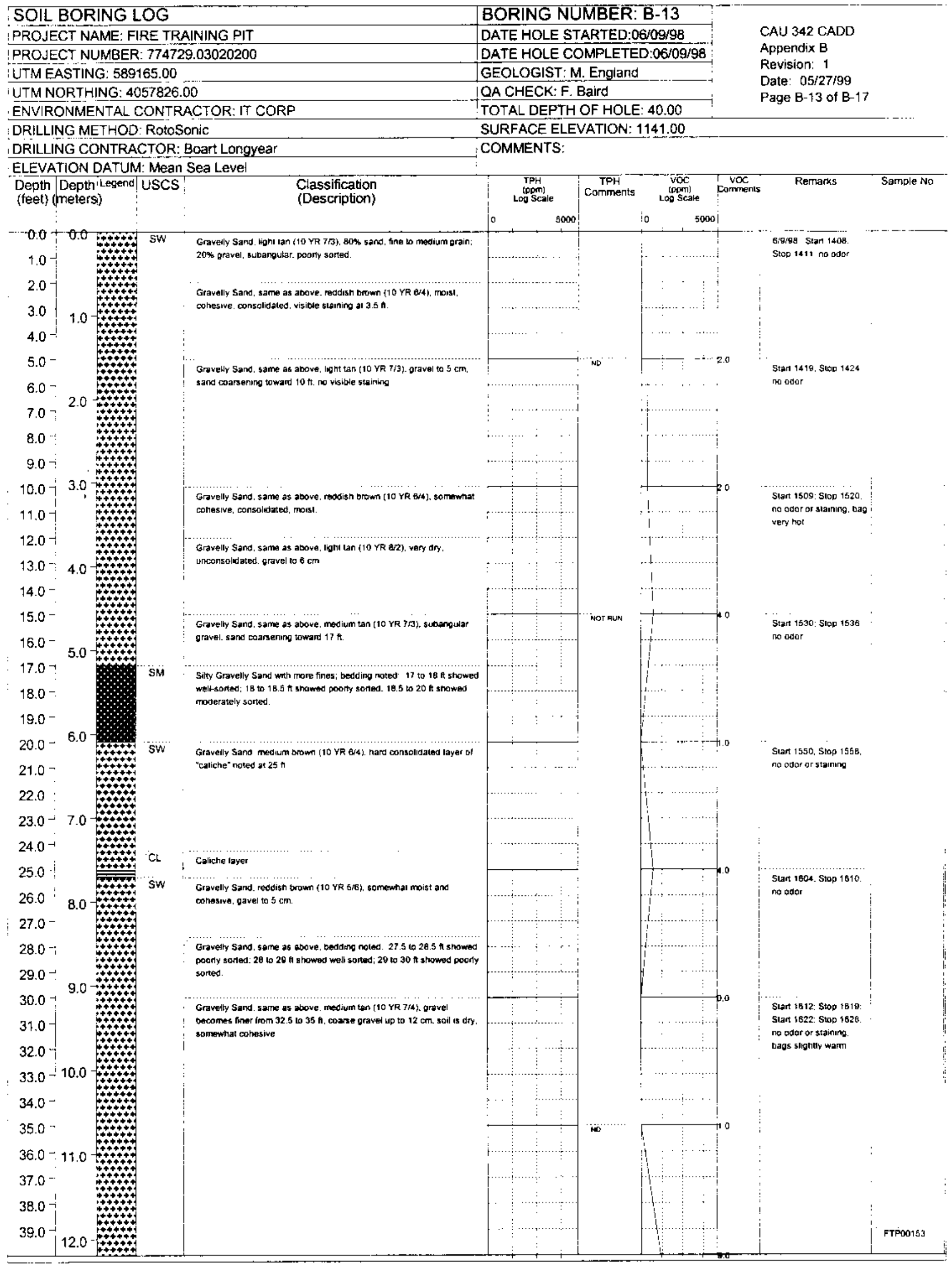




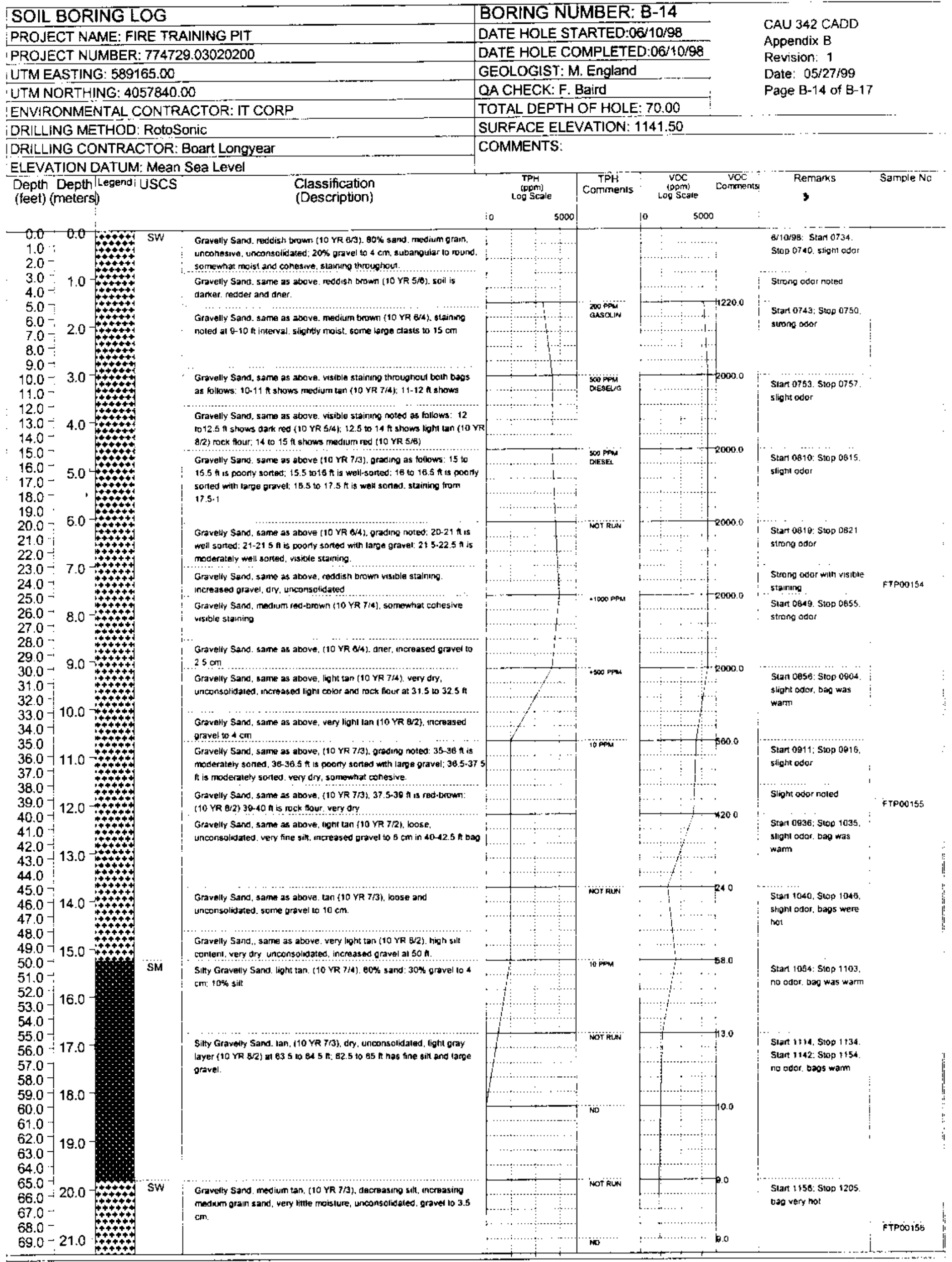




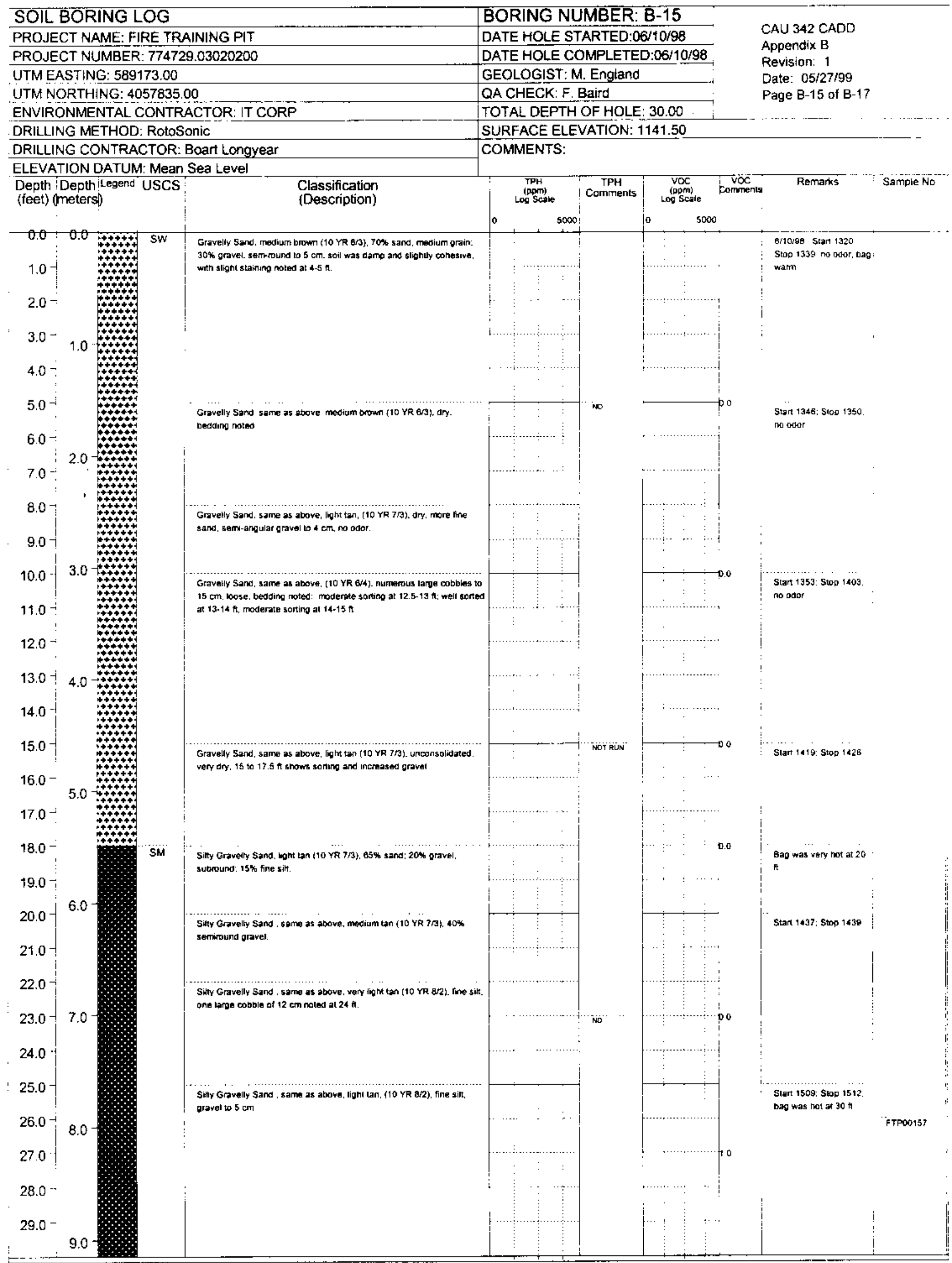




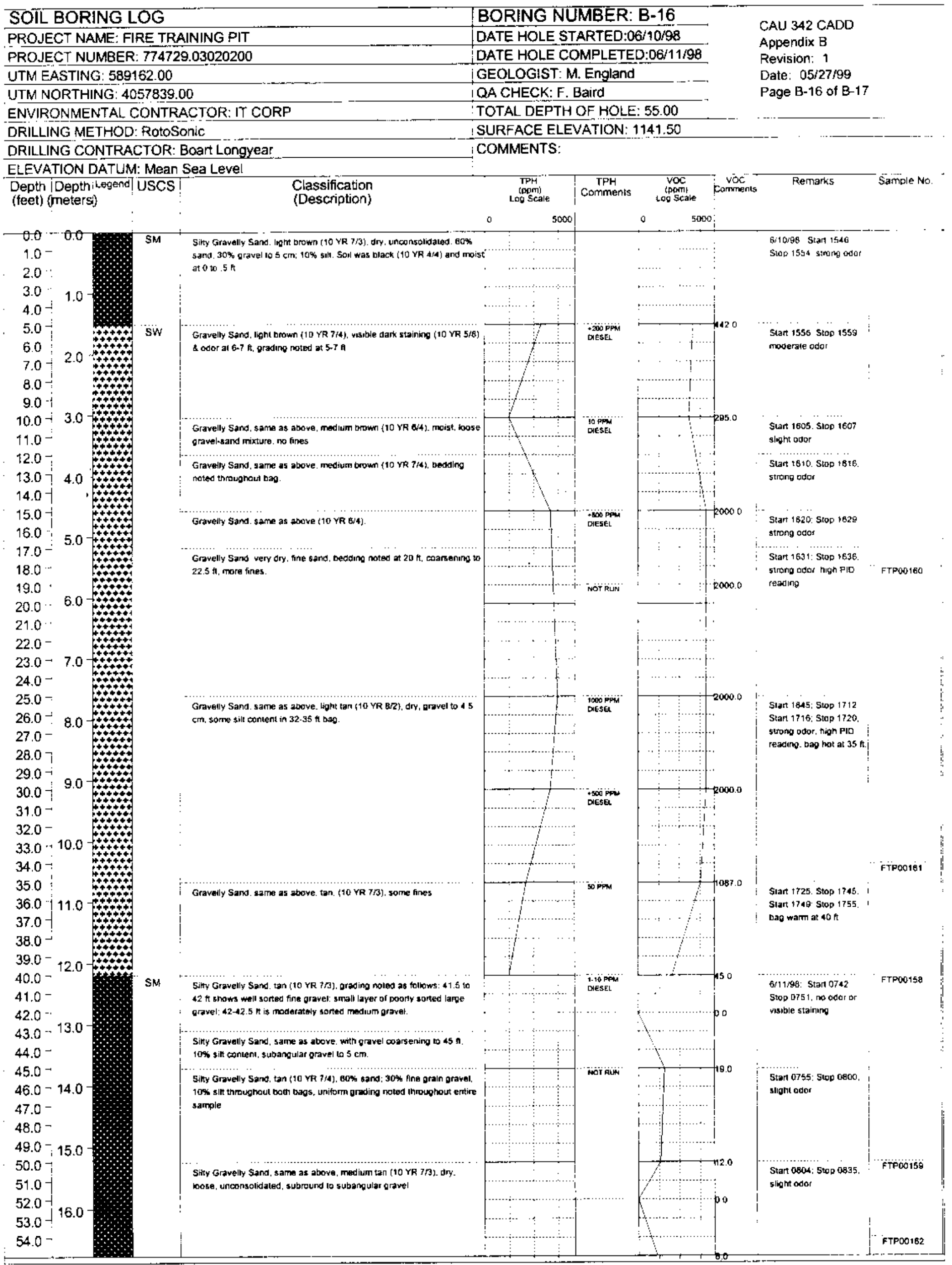




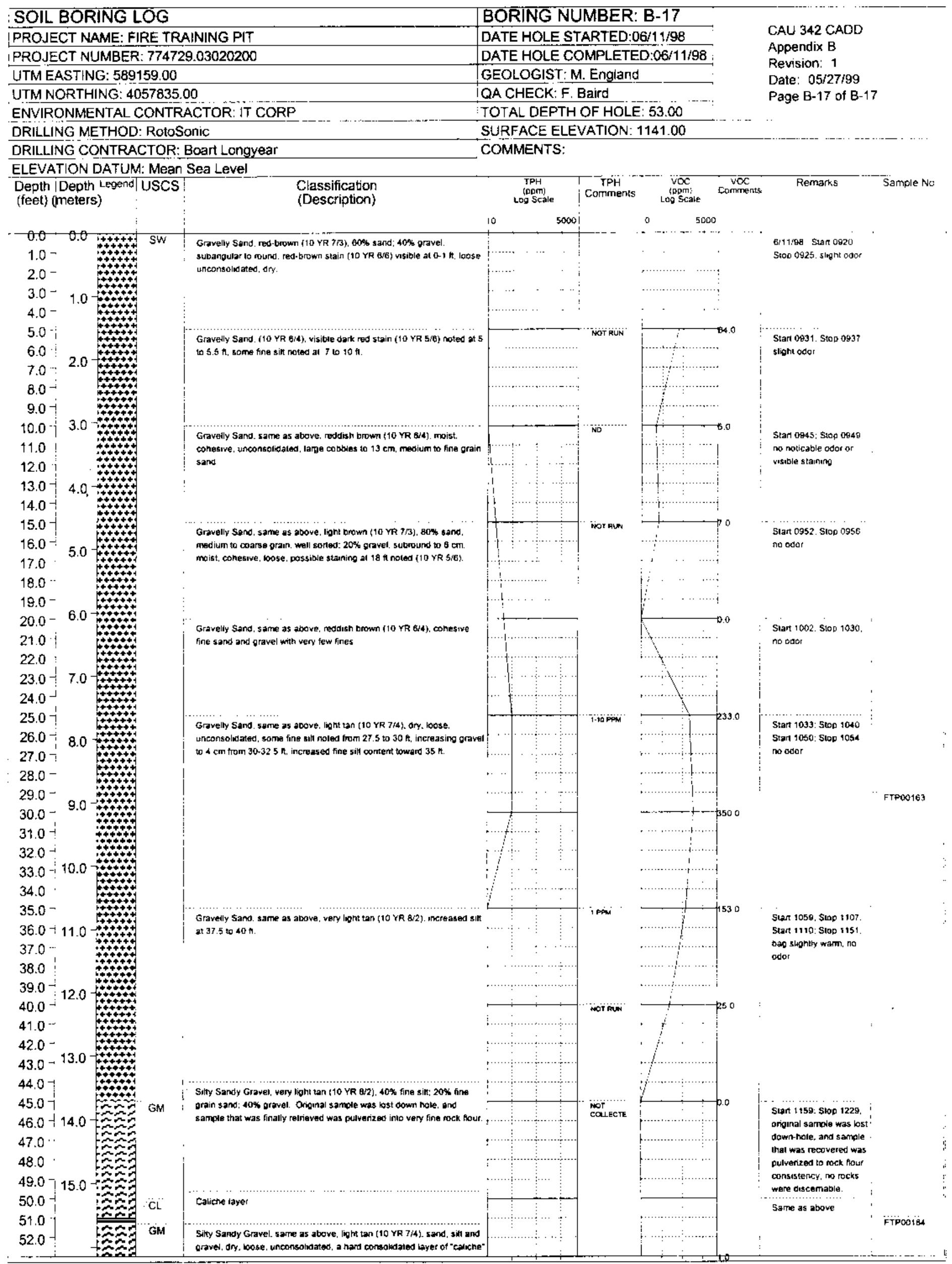




\section{Appendix C}

Geotechnical Sample Results 
Project: $\quad$ CAU 342 Mercury FTP

Report to: International Technology Corporation

Attention : Mr. Ken Beach

Sample Identification
Page : $\quad 1$ of 2

Date of Report : 9-24-98

Project No. : $\mathbf{7 7 4 7 2 9 . 0 3 0 2 0 3 0}$

Reported By: Nancy E. Reid

Reviewed By: Kurt Tolivasia, P.E.

Director of Field Services

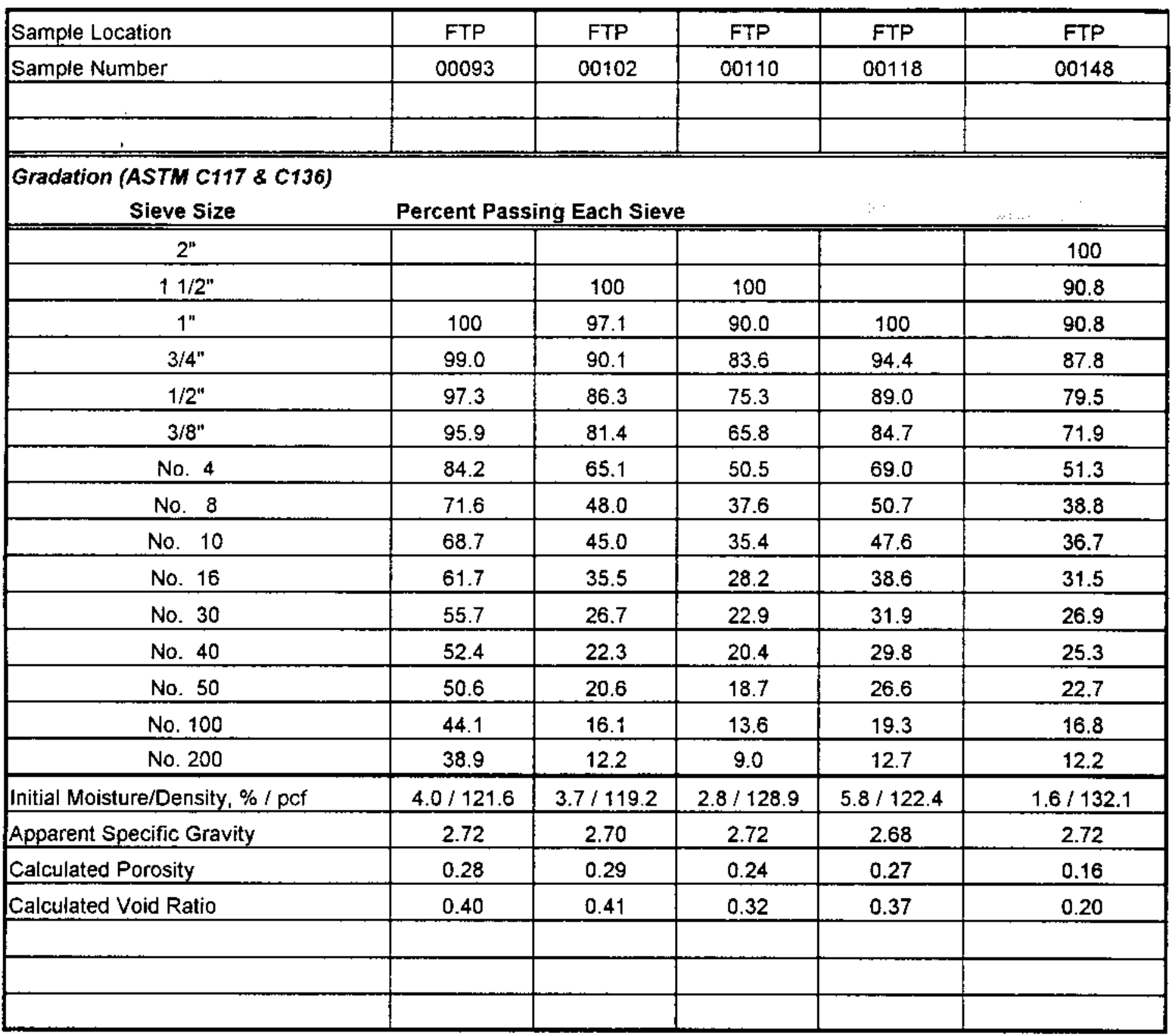

Comments: Hydrometer Analysis (ASTM D422) Not Performed on Sample 00110 ,

Sampled Contaminated with Drillers Foam. 


\section{CONVERSE CONSULTANTS}

REPORT OF AGGREGATE AND SOIL. TEST RESULTS
CAU 342 CADD

Appendix $\mathrm{C}$

Revision: 1

Date: $05 / 27 / 99$

Page $\mathrm{C}-2$ of $\mathrm{C}-23$

Project: $\quad$ CAU 342 Mercury FTP

Report to : International Technology Corporation

Attention: Mr. Ken Beach

Sample Identification :

Reported By: Nancy E. Reid

Reviewed By: Kurt Tolivasia, P.E.

Director of Field Services

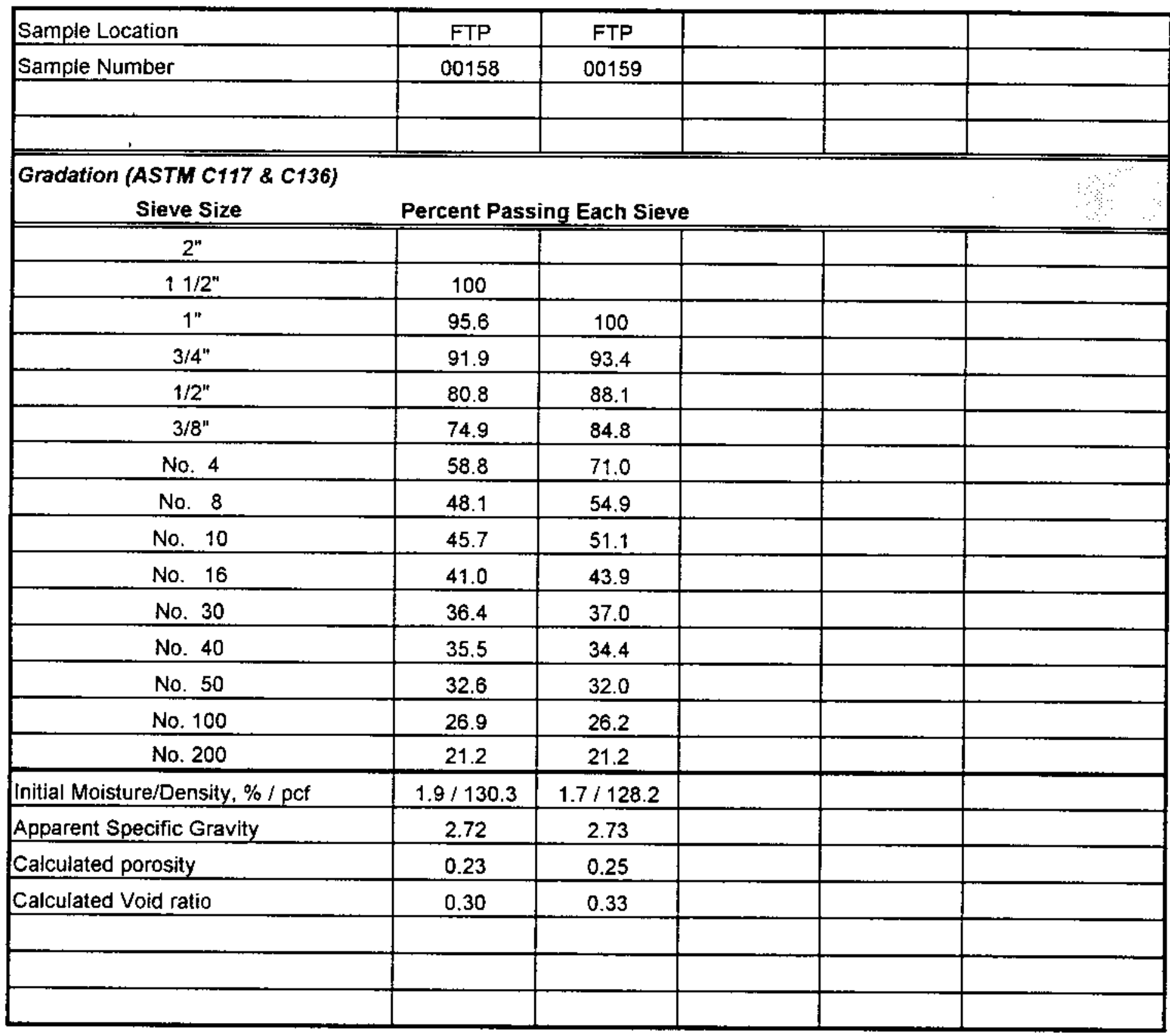

Comments: 


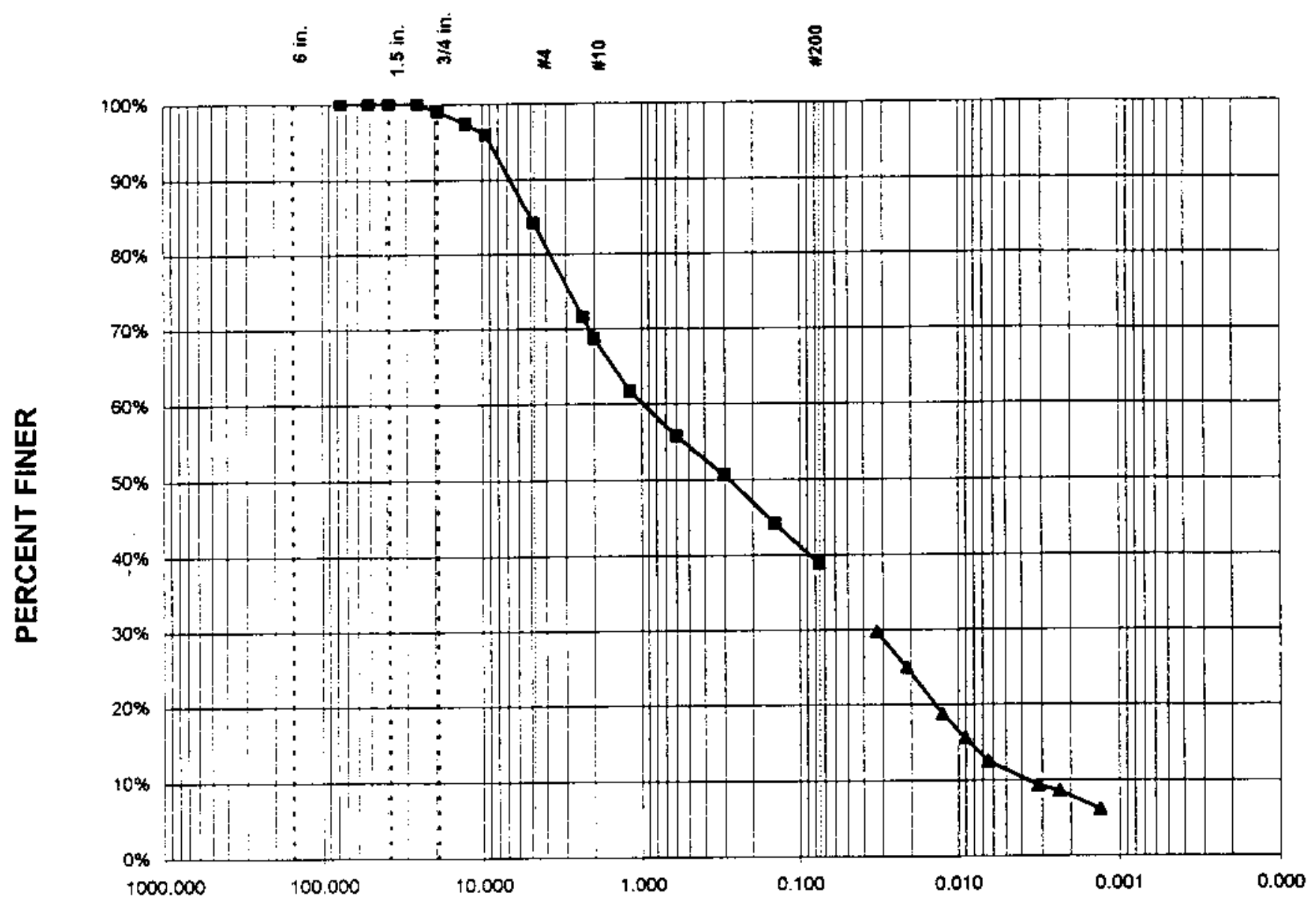

GRAIN SIZE - $\mathrm{mm}$

HYDROMETER TEST SUMMARY

$\begin{array}{rlll}\% \text { GRAVEL }= & 15.79 \% & D_{85}=5.0 & D_{15}= \\ \% \text { SAND }= & 45.34 \% & D_{60}=1.0 & D_{10}= \\ \% \text { SILT \& CLAY }= & 38.87 \% & D_{60}=0.3 & C_{U}= \\ & & D_{30}= & C_{C}=\end{array}$

Project No.: 774729.03020300

Client: International Technology Corporation

Project Name: CAU 342 Mercury FTP

Sample No.: FTP00093

Material Description: Clayey Sand with Gravel 


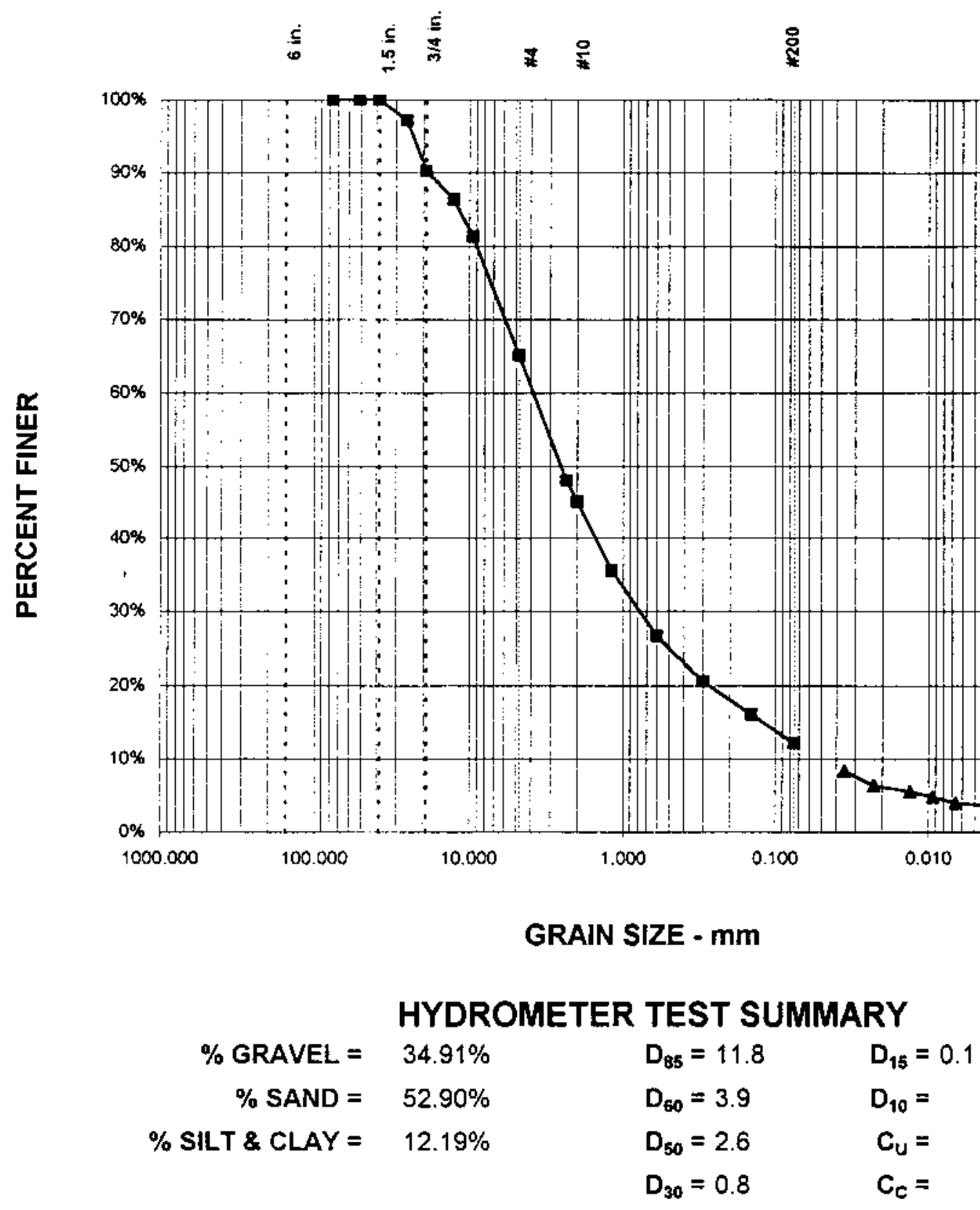

Project No: $\quad 774729.03020300$

Client: International Technology Corporation

Project Name: CAU 342 Mercury FTP

Sample No.: FTP00102

Material Description: Clayey Sand with Gravel

GRAIN SIZE DISTRIBUTION TEST REPORT with HYDROMETER CONVERSE CONSULTANTS, INC. 


\section{GRAIN SIZE DISTRIBUTION GRAPH}

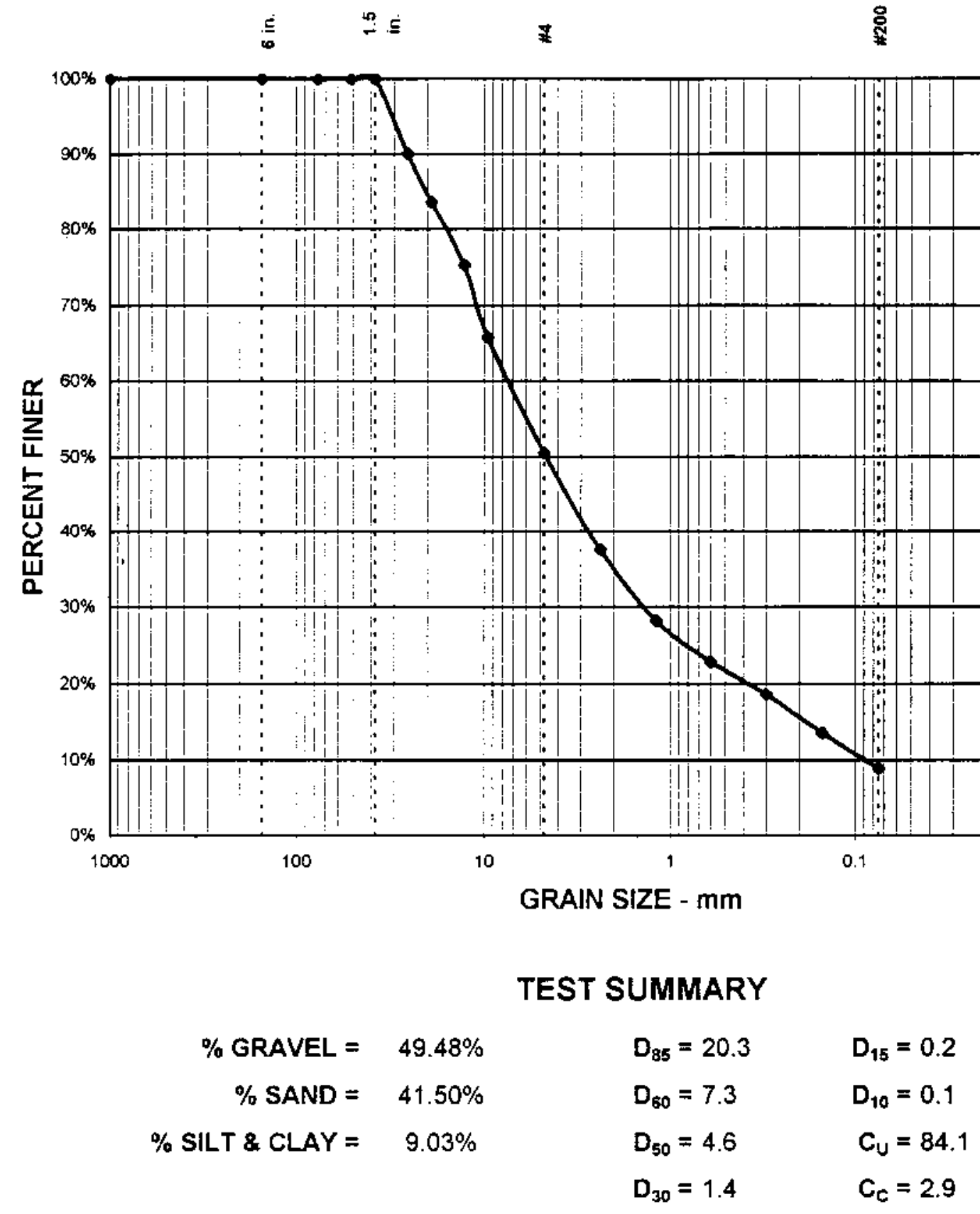

Project No.: 774729.03020300

Project Name: International Technology Corporation

Date: 23-Sep-98

Sample No: FTP00110

Material Description: Well Graded Gravel with Silt \& Sand

GRAIN SIZE DISTRIBUTION TEST REPORT 


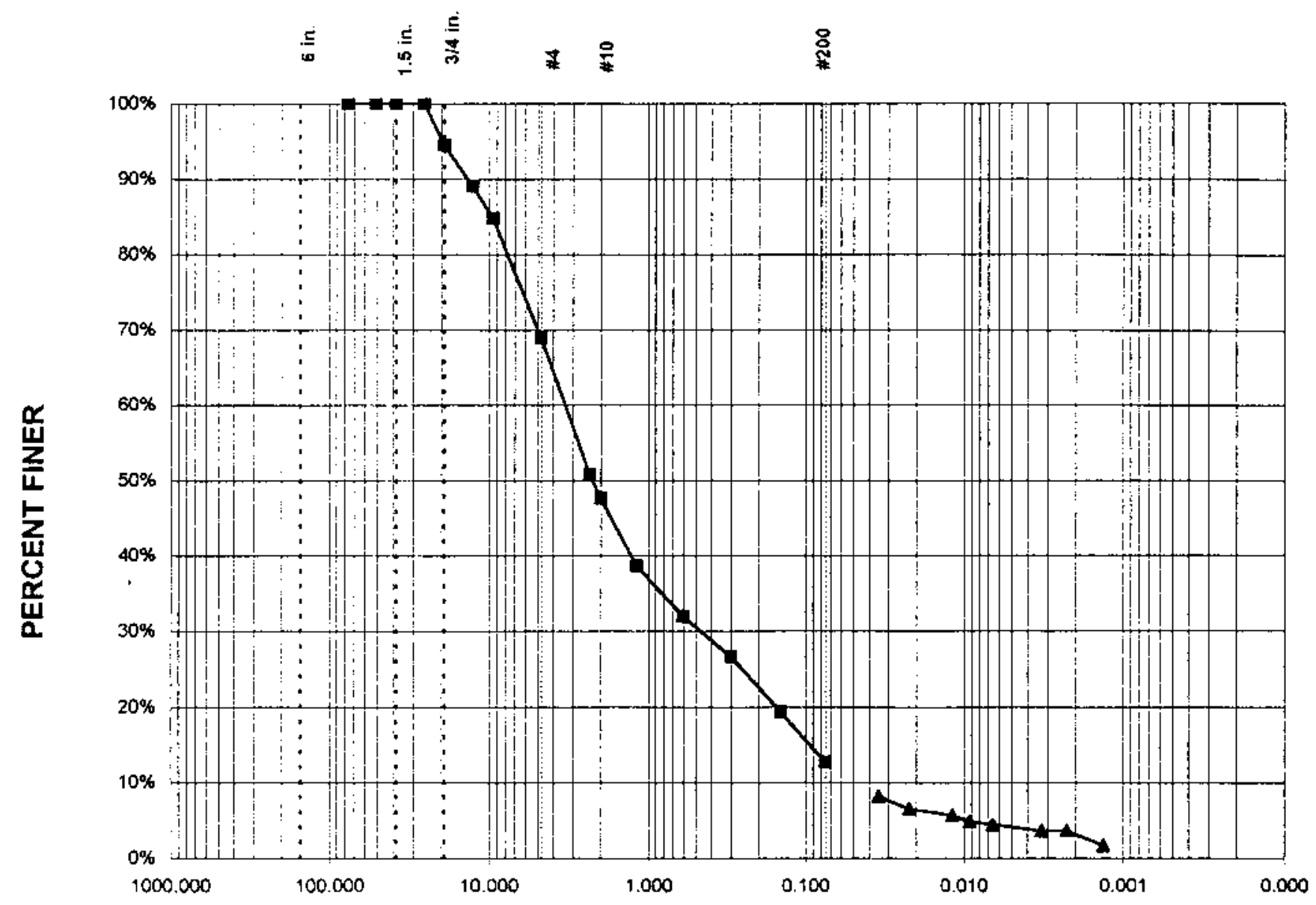

GRAIN SIZE - mm

HYDROMETER TEST SUMMARY

$\begin{array}{rlll}\text { \% GRAVEL }= & 31.03 \% & D_{85}=9.7 & D_{15}=0.1 \\ \% \text { SAND }= & 56.27 \% & D_{80}=3.4 & D_{10}= \\ \% \text { SILT \& CLAY }= & 12.70 \% & D_{50}=2.3 & C_{U}= \\ & & D_{30}=0.5 & C_{C}=\end{array}$

Project No.: 774729.03020300

Client: International Technology Corporation

Project Name: CAU 342 Mercury FTP

Sample No.: FTP00118

Material Description: Silty Sand with Gravel 


\section{GRAIN SIZE DISTRIBUTION GRAPH}

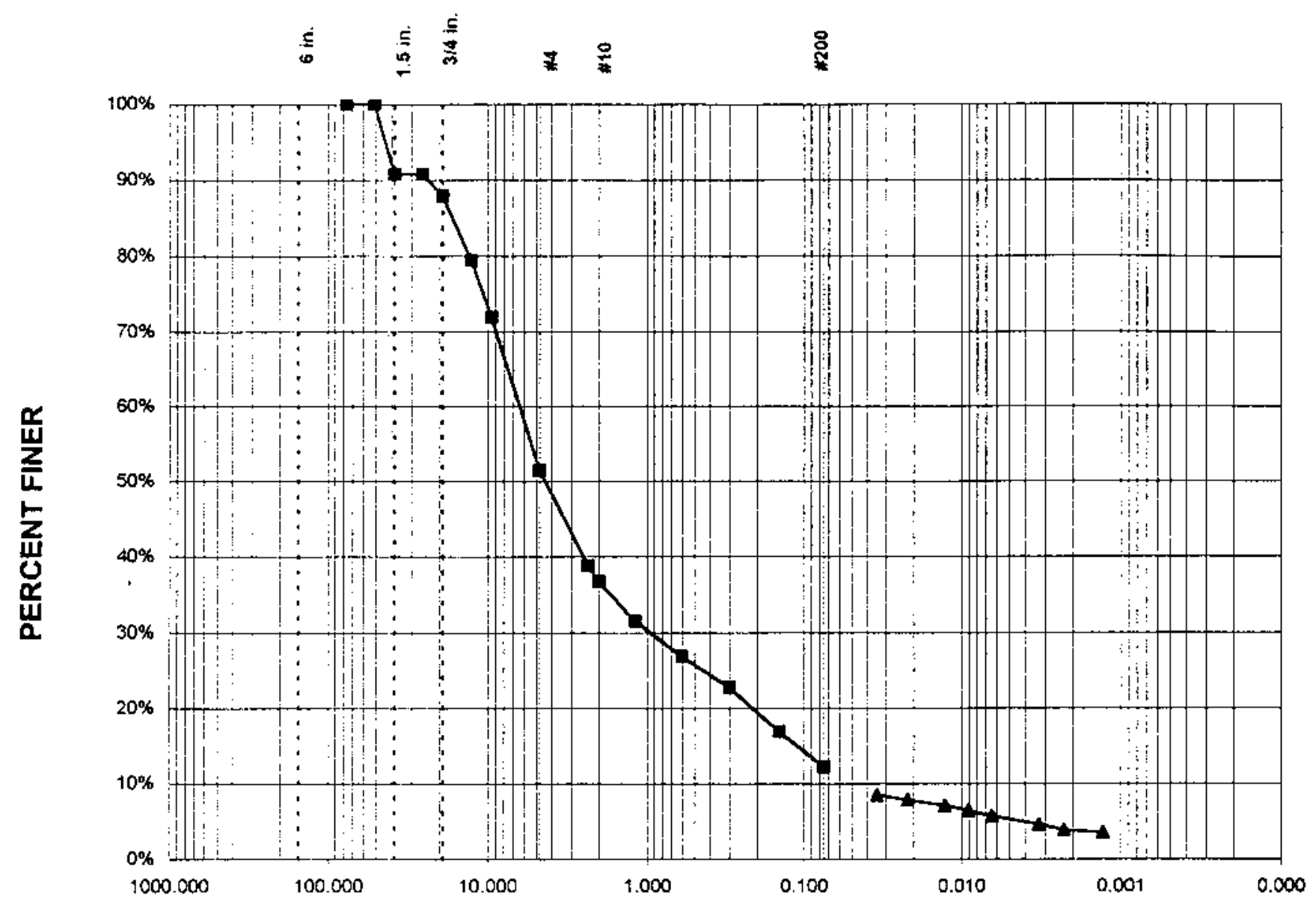

GRAIN SIZE - mm

\section{HYDROMETER TEST SUMMARY}

$\begin{array}{rlll}\text { \% GRAVEL }=48.67 \% & D_{85}=16.6 & D_{15}=0.1 \\ \% \text { SAND }=39.17 \% & D_{60}=6.4 & D_{10}= \\ \% \text { SILT \& CLAY }= & 12.16 \% & D_{50}=4.4 & C_{u}= \\ & & D_{30}=0.9 & C_{C}=\end{array}$

Project No.: 774729.03020300

Client: International Technology Corporation

Project Name: CAU 342 Mercury FTP

Sample No.: FTP00148

Material Description: Silty Gravel with Sand

GRAIN SIZE DISTRIBUTION TEST REPORT with HYDROMETER 


\section{GRAIN SIZE DISTRIBUTION GRAPH}

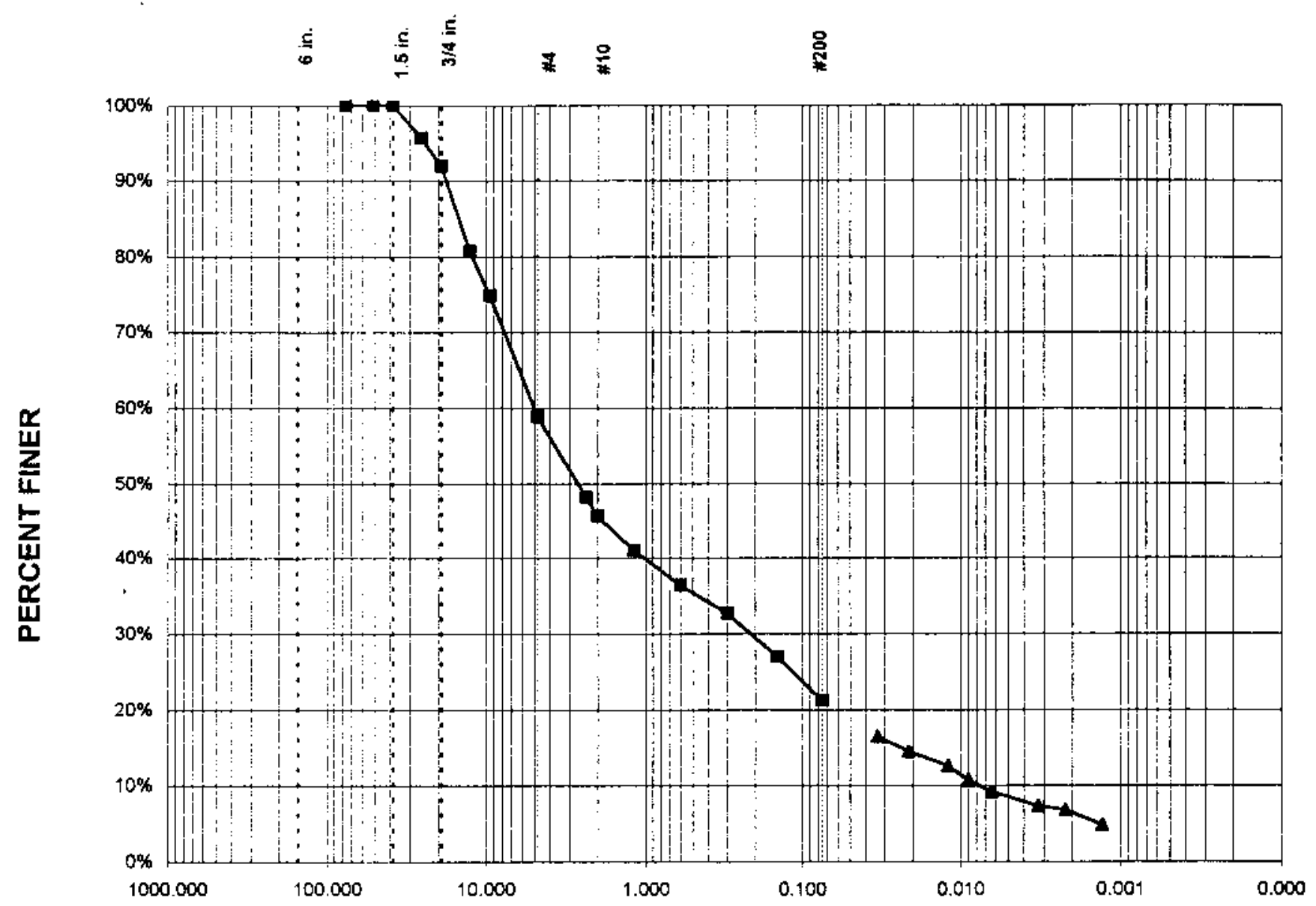

GRAIN SIZE - mm

HYDROMETER TEST SUMMARY

$\begin{array}{rlll}\% \text { GRAVEL }= & 41.16 \% & D_{85}=14.8 & D_{15}= \\ \% \text { SAND }= & 37.67 \% & D_{60}=5.0 & D_{10}= \\ \% \text { SILT \& CLAY }= & 21.17 \% & D_{50}=2.7 & C_{U}= \\ & & D_{30}=0.2 & C_{C}=\end{array}$

Project No.: 774729.03020300

Client: International Technology Corporation

Project Name: CAU 342 Mercury FTP

Sample No.: FTP00158

Material Description: Clayey Gravel with Sand 


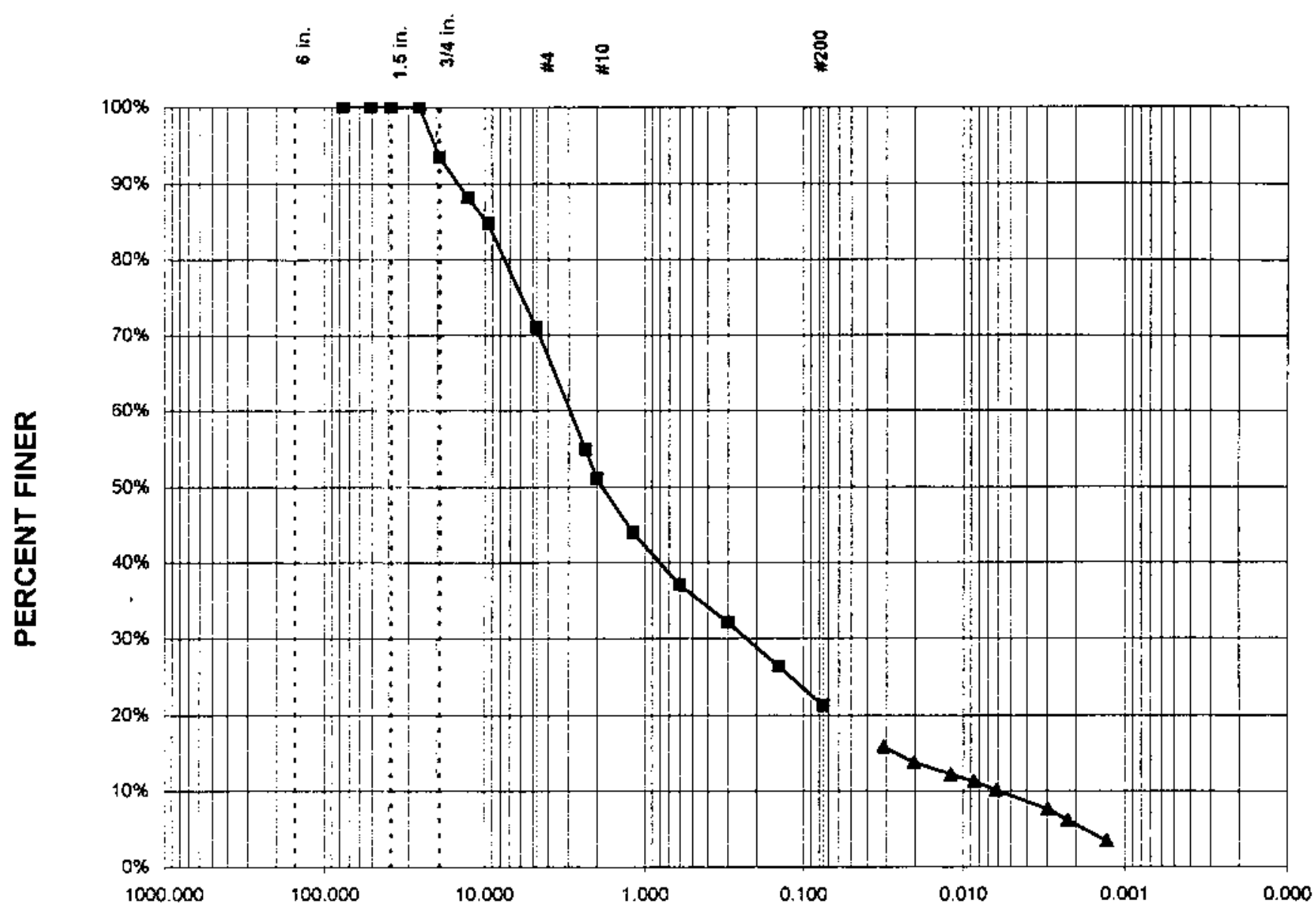

GRAIN SIZE - mm

HYDROMETER TEST SUMMARY

$\begin{array}{rlll}\text { \% GRAVEL }= & 29.01 \% & \mathrm{D}_{85}=9.7 & \mathrm{D}_{15}= \\ \% \text { SAND }= & 49.81 \% & \mathrm{D}_{60}=2.9 & \mathrm{D}_{10}= \\ \% \text { SILT \& CLAY }= & 21.17 \% & \mathrm{D}_{50}=1.7 & \mathrm{C}_{\mathrm{U}}= \\ & & \mathrm{D}_{30}=0.2 & \mathrm{C}_{\mathrm{C}}=\end{array}$

Project No.: 774729.03020300

Client: International Technology Corporation

Project Name: CAU 342 Mercury FTP

Sample No.: FTP00159

Material Description: Clayey Sand with Gravel 


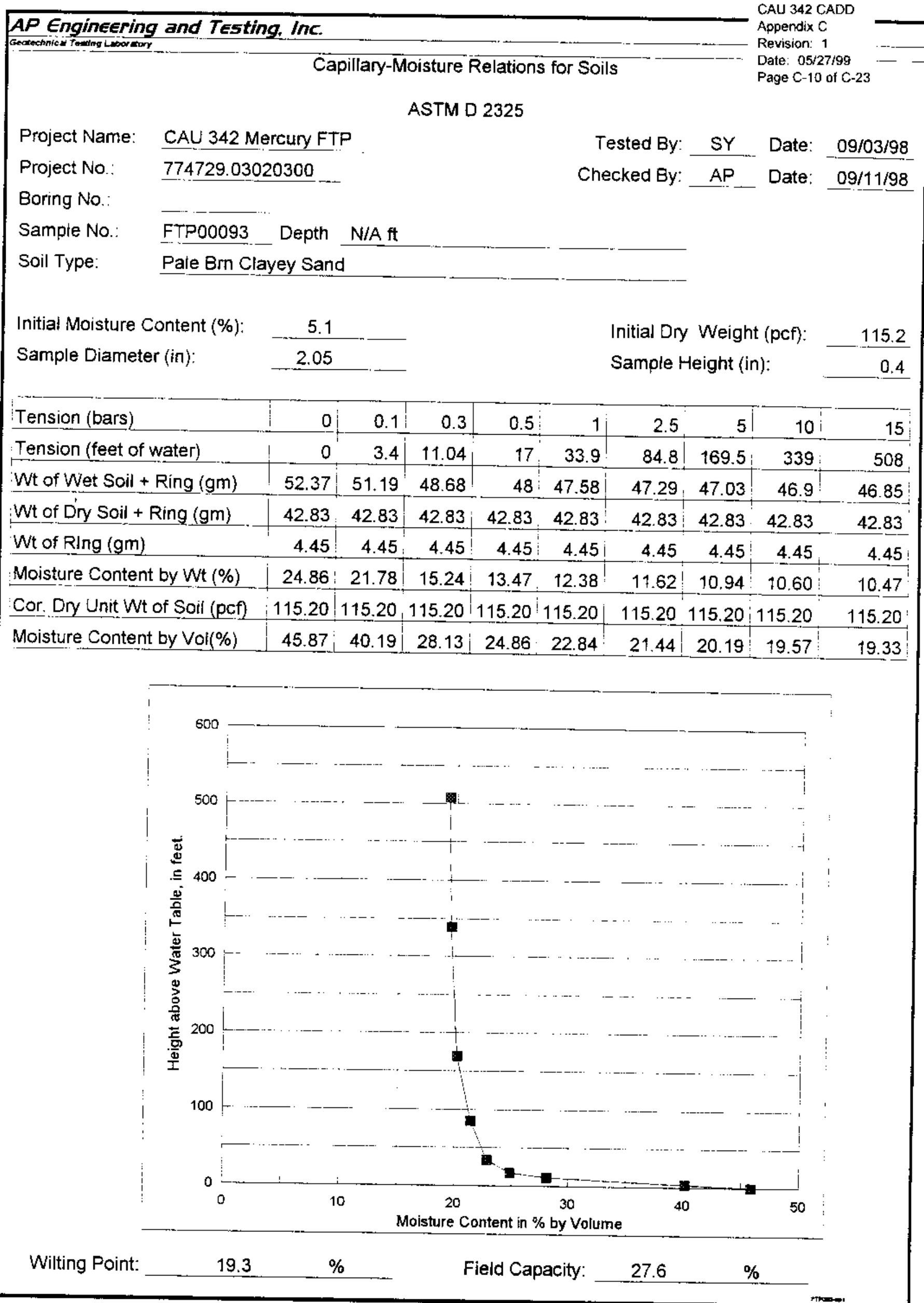


AP Engineering and Testing. Inc.

Capillary-Moisture Relations for Soils

ASTM D 2325

Project Name: $\quad$ CAU 342 Mercury FTP

Project No: : $\quad 774729.03020300$

Tested By: SY_Date: 09/03/98

Checked By: AP

Boring No.:

Sample No.: FTP00102 Depth N/A ft

Soil Type: $\quad$ Pale Brn Clayey Sand

Initial Moisture Content (\%):

5.6

Initial Dry Weight (pcf):

117.2

Sample Diameter (in):

2.05

Sample Height (in):

0.4

\begin{tabular}{|l|r|r|r|r|r|r|r|r|r|}
\hline Tension (bars) & 0 & 0.1 & 0.3 & 0.5 & 1 & 2.5 & 5 & 10 & 15 \\
\hline Tension (feet of water) & 0 & 3.4 & 11.04 & 17 & 33.9 & 84.8 & 169.5 & 339 & 508 \\
\hline Wt of Wet Soil + Ring (gm) & 54.31 & 52.47 & 49.97 & 49.34 & 48.85 & 48.55 & 48.23 & 48.08 & 48.01 \\
\hline Wt of Dry Soil + Ring (gm) & 43.68 & 43.68 & 43.68 & 43.68 & 43.68 & 43.68 & 43.68 & 43.68 & 43.68 \\
\hline Wt of RIng (gm) & 4.14 & 4.14 & 4.14 & 4.14 & 4.14 & 4.14 & 4.14 & 4.14 & 4.14 \\
\hline Moisture Content by Wt (\%) & 26.88 & 22.23 & 15.91 & 14.31 & 13.08 & 12.32 & 11.51 & 11.13 & 10.95 \\
\hline Cor. Dry Unit Wt of Soil (pcf) & 110.40 & 110.40 & 110.40 & 110.40 & 110.40 & 110.40 & 110.40 & 110.40 & 110.40 \\
\hline Moisture Content by Vol(\%) & 47.54 & 39.31 & 28.13 & 25.31 & 23.12 & 21.78 & 20.35 & 19.68 & 19.37 \\
\hline
\end{tabular}

600

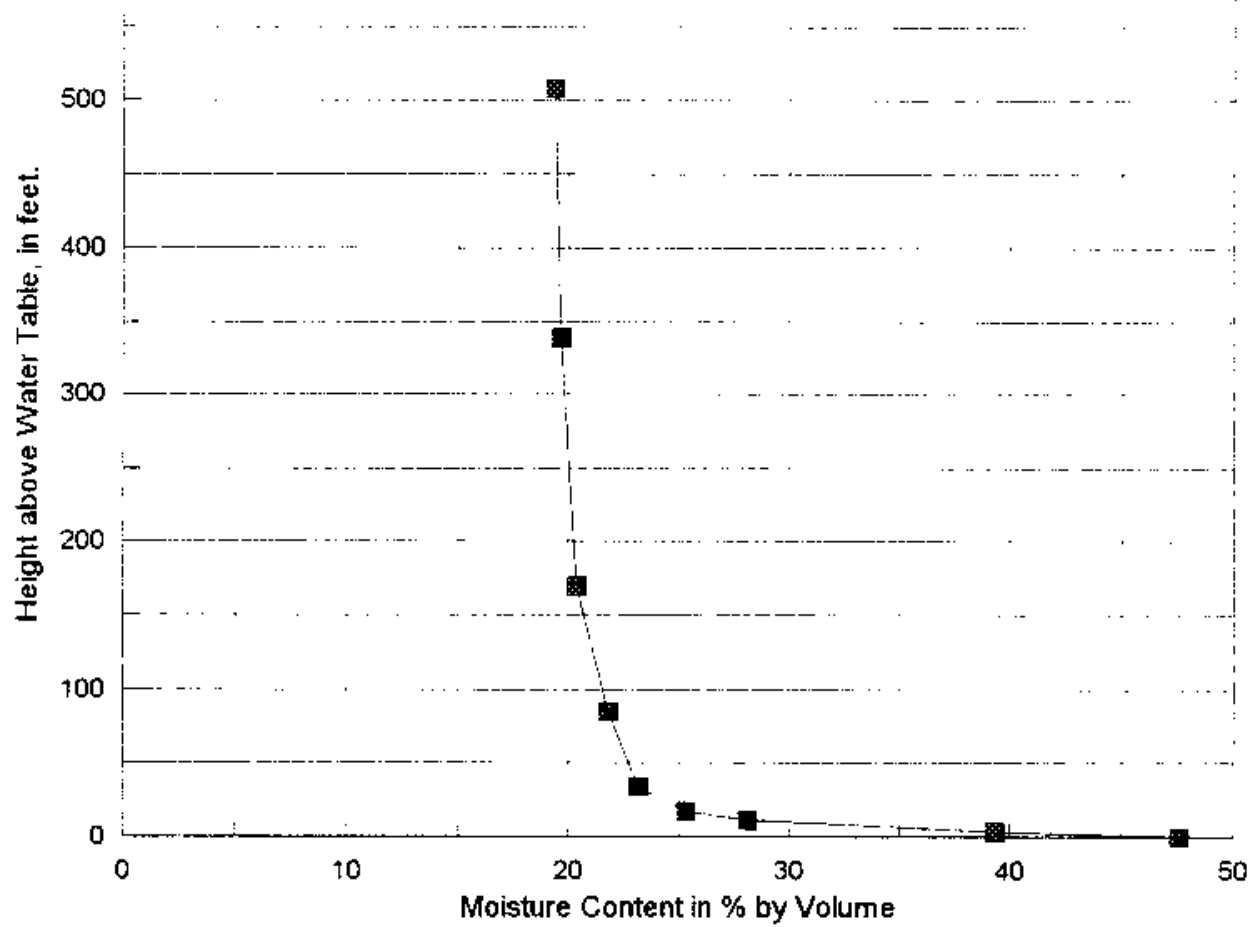

Wilting Point:

19.4

$\%$

Field Capacity:

27.7

$\%$ 
AP Engineering and Testing. InC.

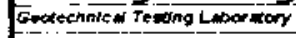

Capillary-Moisture Relations for Soils

CAU 342 CADD

Appendix C

Revision: 1

Date: $05 / 27 / 99$

Page C-12 of C-23
Project Name: CAU 342 Mercury FTP

Project No: $\quad$ 774729.03020300

Boring No:

Sample No:

Soll Type:
FTP00110 Depth N/A ft

Pale Brn Clayey Sand
Tested By: SY Date: 09/03/98

Checked By: AP

Date: $09 / 11 / 98$

\begin{tabular}{|c|c|c|c|c|c|c|c|c|c|}
\hline Initial Moisture Content (\%): & 5.1 & & & & & Initial Dry & Weigh & $(\mathrm{pcf}):$ & 108.7 \\
\hline Sampte Diameter (in): & 2.05 & & & & & Sample & eight (ir & & 0.4 \\
\hline Tension (bars) & 0 & 0.1 & 0.3 & 0.5 & $1:$ & 2.5 & 5 & 10 & 15 \\
\hline Tension (feet of water) & 0 & 3.4 & 11.04 & 17 & 33.9 & 84.8 & 169.5 & 339 & 508 \\
\hline Wt of Wet Soil + Ring (gm) & 48.42 & 45.51 & 45.02 & 44.89 & 44.53 & 44.18 & 44.02 & 43.98 & 43.94 \\
\hline Wt of Dry Soii + Ring (gm) & 39.5 & 39.5 & 39.5 & 39.5 & 39.5 & 39.5 & 39.5 & 39.5 & 39.5 \\
\hline Wt of RIng (gm) & 4.36 & 4.36 & 4.36 & 4.36 & 4.36 & 4.36 & 4.36 & 4.36 & 4.36 \\
\hline Moisture Content by Wt (\%) & 25.38 & 17.10 & 15.71 & 15.34 & 14.31: & 13.32 & 12.86 & 12.75 & 12.64 \\
\hline Cor. Dry Unit Wt of Soil (pcf) & 108.66 & 108.66 & 108.66 & 108.66 & 108.66 & 108.66 & 108.66 & 108.66 & 108.66 \\
\hline Moisture Content by Vol(\%) & 44.18 & 29.77 & 27.34 & 26.70 & 24.91 & 23.18 & 22.39 & 22.19 & 21.99 \\
\hline
\end{tabular}

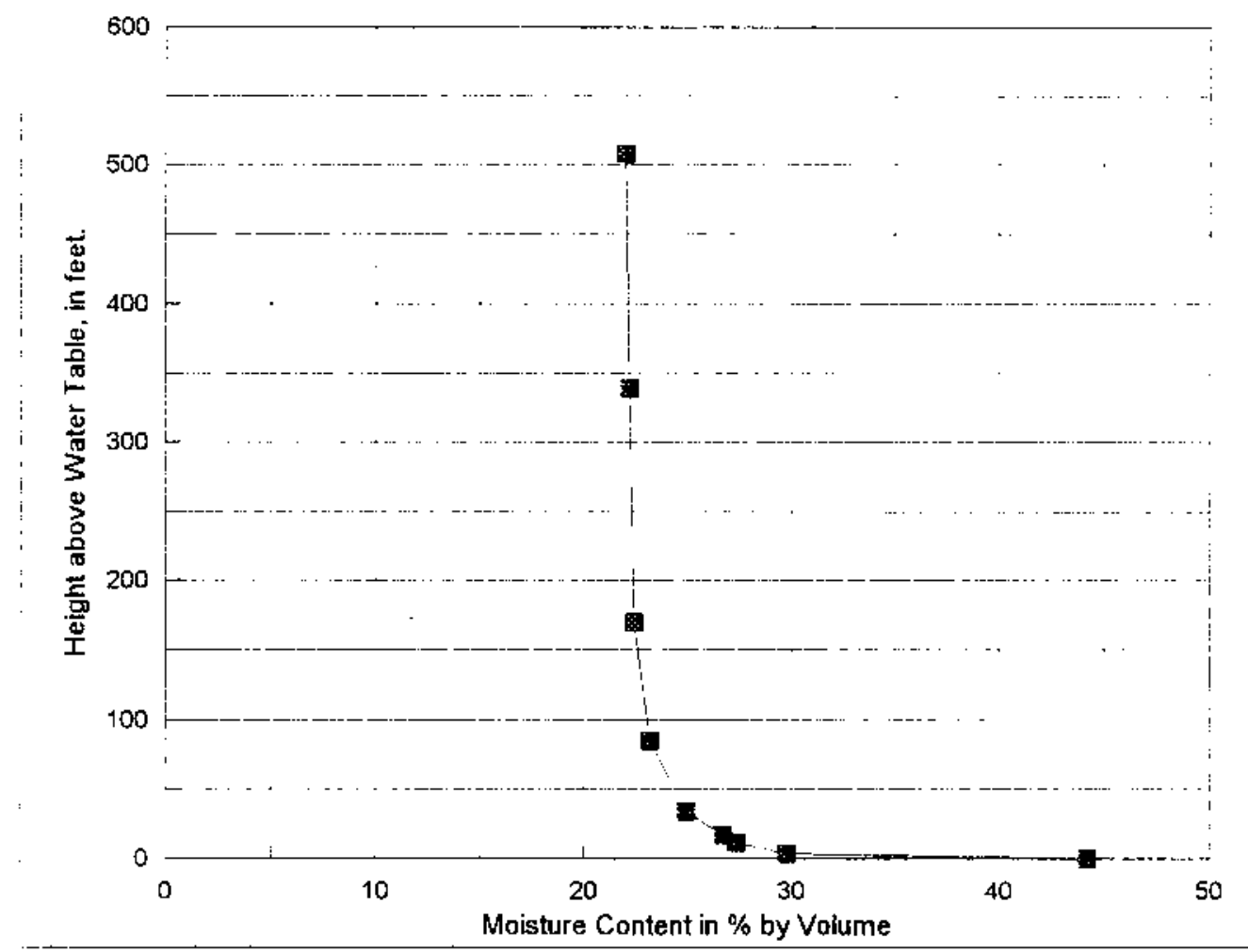

Wilting Point:

22.0

$\%$

Field Capacity:

27.2

$\%$ 
AP Engineering and Testing, Inc.

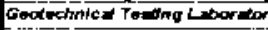

Capillary-Moisture Relations for Soils

ASTM D 2325

Project Name: CAU 342 Mercury FTP

Project No: $\quad 774729.03020300$

Boring No:

Sample No: FTP00118 Depth N/Aft

Soil Type: $\quad$ Pale Brn Clayey Sand

Initial Moisture Content (\%):

Sample Diameter (іп):

$\begin{array}{r}7.2 \\ \hline 2.05 \\ \hline\end{array}$

Initial Dry Weight (pcf):

Sample Height (in):

Tested By: SY Date: 09/03/98

Checked By: AP Date: 09/11/98

Revision: 1

Date: 05/27/99

Page $\mathrm{C}-13$ of $\mathrm{C}-23$

\begin{tabular}{|l|r|r|r|r|r|r|r|r|r|}
\hline Tension (bars) & 0 & 0.1 & 0.3 & 0.5 & 1 & 2.5 & 5 & 10 & 15 \\
\hline Tension (feet of water) & 0 & 3.4 & 11.04 & 17 & 33.9 & 84.8 & 169.5 & 339 & 508 \\
\hline Wt of Wet Soil + Ring (gm) & 51.24 & 50.06 & 47.6 & 47.17 & 46.96 & 46.66 & 46.44 & 46.38 & 46.33 \\
\hline Wt of Dry Soil + Ring (gm) & 42.75 & 42.75 & 42.75 & 42.75 & 42.75 & 42.75 & 42.75 & 42.75 & 42.75 \\
\hline Wt of RIng (gm) & 4.4 & 4.4 & 4.4 & 4.4 & 4.4 & 4.4 & 4.4 & 4.4 & 4.4 \\
Moisture Content by Wt (\%) & 22.14 & 19.06 & 12.65 & 11.53 & 10.98 & 10.20 & 9.62 & 9.47 & 9.34 \\
\hline Cor. Dry Unit Wt of Soil (pcf) & 116.18 & 116.18 & 116.18 & 116.18 & 116.18 & 116.18 & 116.18 & 116.18 & 116.18 \\
\hline Moisture Content by Vol(\%) & 41.20 & 35.47 & 23.53 & 21.45 & 20.43 & 18.97 & 17.91 & 17.61 & 17.37 \\
\hline
\end{tabular}

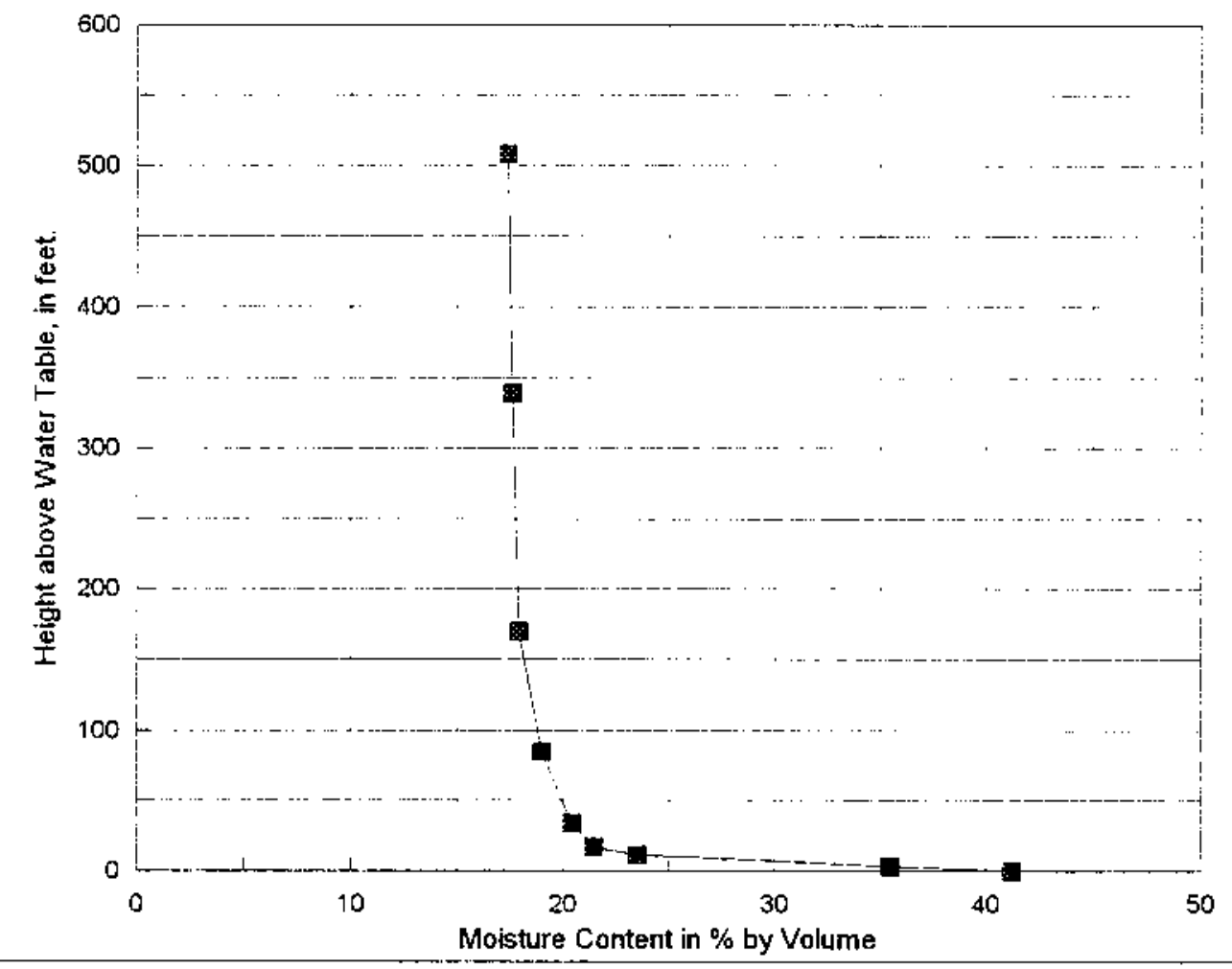

Wilting Point:

17.4

Field Capacity:

23.2

$\%$ 


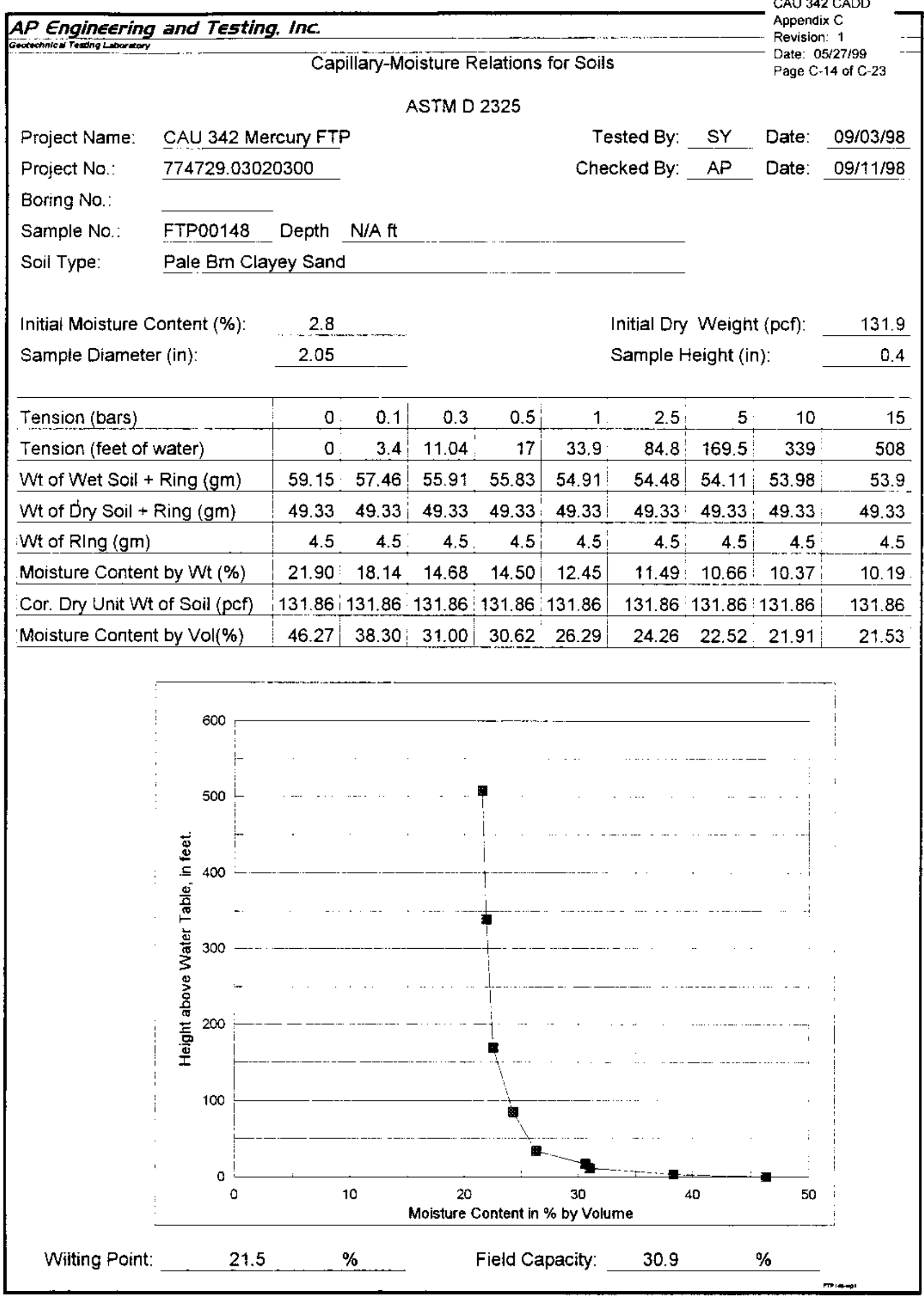




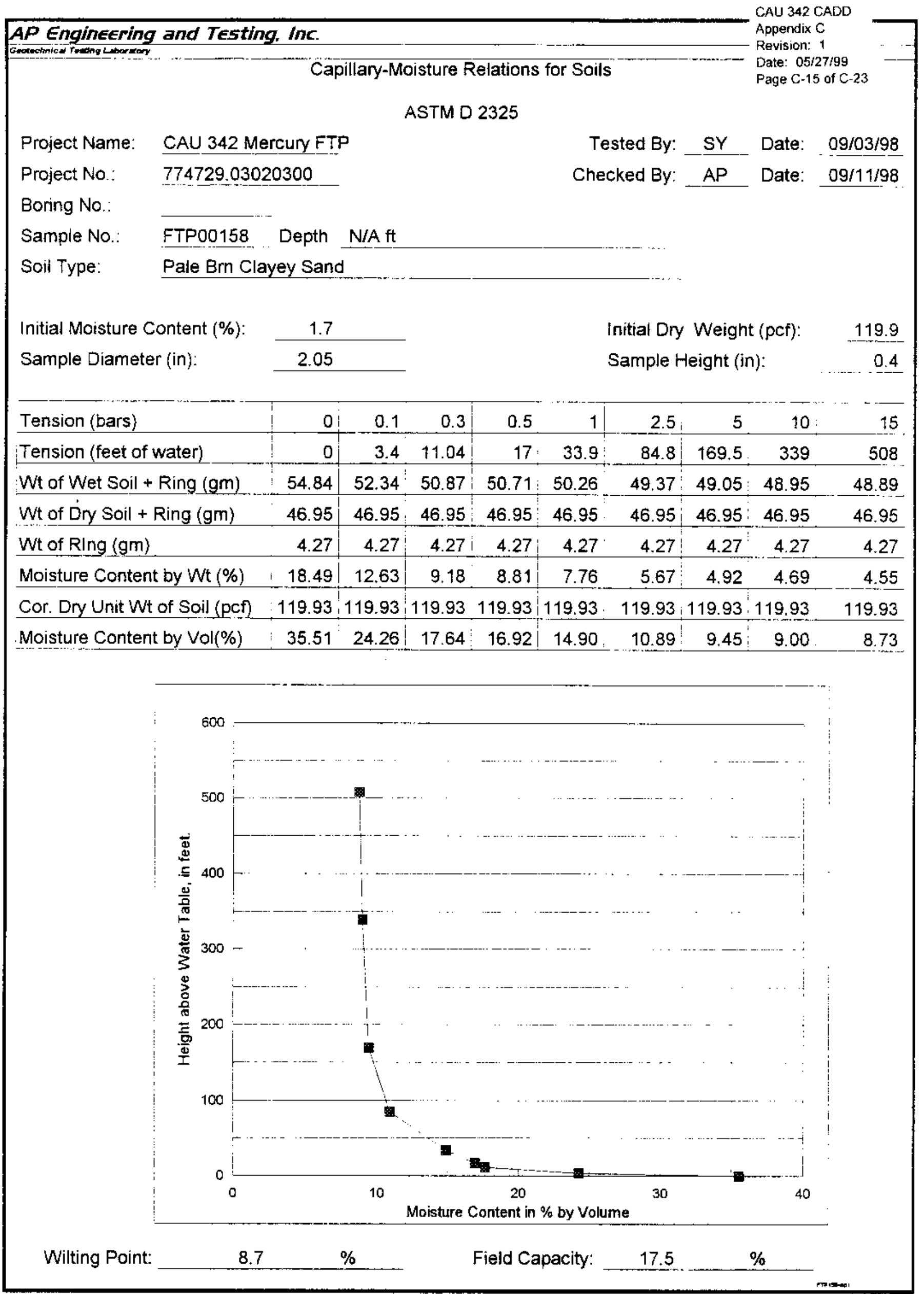


ASTM D 2325

Project Name: CAU 342 Mercury FTP

Project No:: $\quad 774729.03020300$

Boring No.:

Sample No:

Soil Type:

\section{FTP00159 Depth N/A ft}

Pale Brn Sandy Silt
Initial Moisture Content (\%):

Sample Diameter (in):

$\begin{array}{r}4.0 \\ \hline 2.05 \\ \hline\end{array}$

Initial Dry Weight (pcf):

Sample Height (in):
108.1

0.4

\begin{tabular}{|c|c|c|c|c|c|c|c|c|c|}
\hline Tension (bars) & 0 & 0.1 & 0.3 & 0.5 & 1 & 2.5 & 5 & 10 & 15 \\
\hline Tension (feet of water) & 0 & 3.4 & 11.04 & 17 & 33.9 & 84.8 & 169.5 & 339 & 508 \\
\hline Wt of Wet Soil + Ring $(\mathrm{gm})$ & 51.2 & 50.88 & 48.94 & 47.8 & 47.32 & 46.83 & 46.47 & 46.22 & 46.14 \\
\hline Wt of Dry Soil + Ring (gm) & 41.22 & 41.22 & 41.22 & 41.22 & 41.22 & 41.22 & 41.22 & 41.22 & 41.22 \\
\hline iWto & 4.5 & 4.5 & 4.5 & 4.5 & 4.5 & 4.5 & 4.5 & 4.5 & 4 \\
\hline Moisture Content by Wt (\%) & 27.18 & 26.31 & 21.02 & 17.92 & 16.61 & 15.28 & 14.30 & 13.62 & 13.40 \\
\hline Cor. Ury und wi o & 108.11 & 108.11 & 108.11: & 108.11 & 108.11 & 108.11 & 108.11 & 108.11 & 108.11 \\
\hline Moisture Content by Vol(\%) & 47.06 & 45.55 & $36.41:$ & 31.03 & 28.77 & 26.46 & 24.76 & 23.58 & 23.20 \\
\hline
\end{tabular}

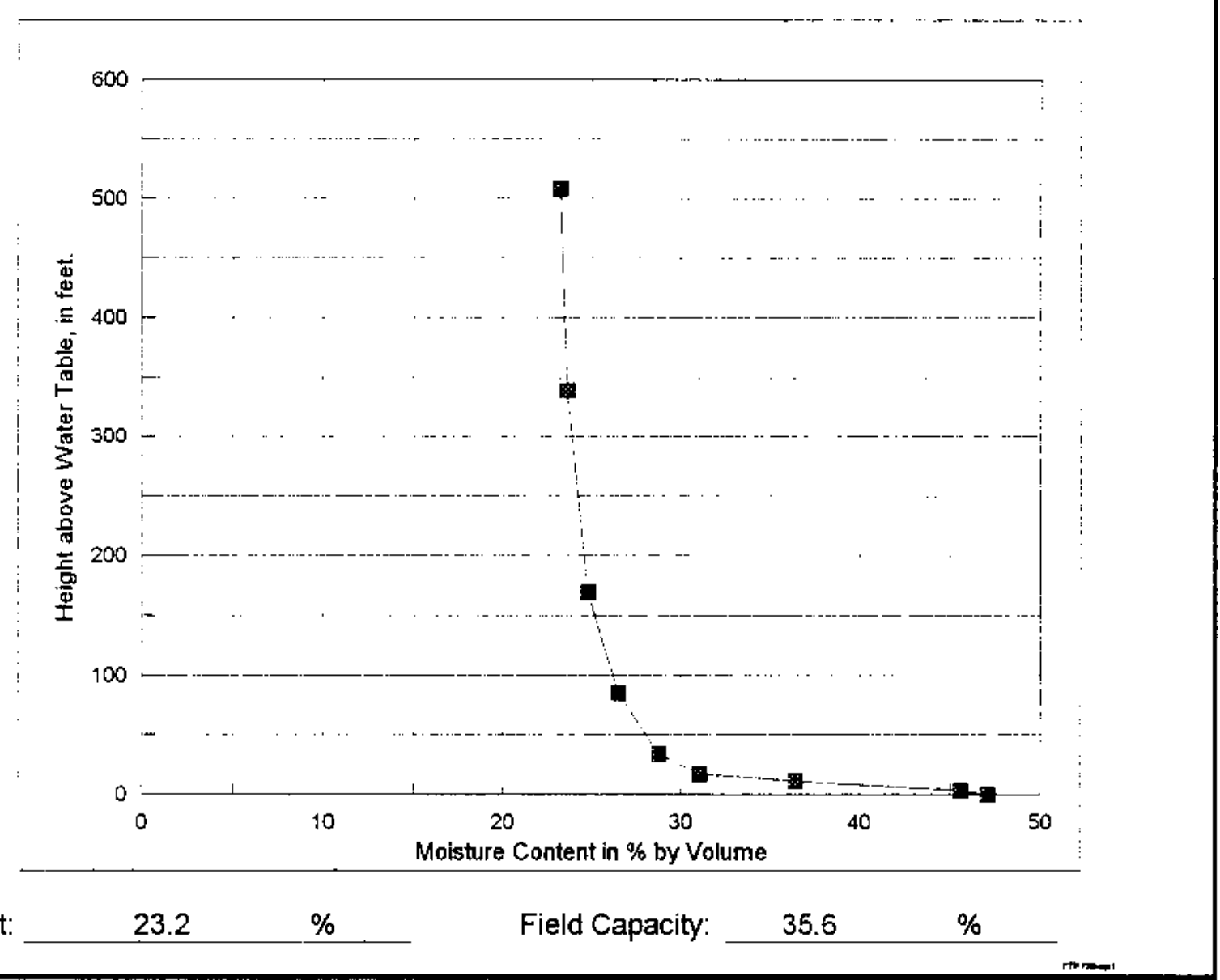

Wilting Point: 23.2

Field Capacity: 


\section{FLEXIBLE WALL HYDRAULIC CONDUCTIVITY TEST \\ ASTM D5084}

$\begin{array}{ll}\text { Project Name: } & \text { CAU } 342 \text { Mercury FTP } \\ \text { Project No: } & \text { R74729.03020300 } \\ \text { Boring No.: } & \text { FTPO0093 Depth: N/A feet } \\ \text { Sample No:: } & \text { Pale Brn Clayey Sand } \\ \text { Soil Description: } & \text { Brass Tube } \\ \text { Test Condition: } & \text { Confining Pressure }=\end{array}$

\begin{tabular}{|c|c|c|c|}
\hline Tested by & $\mathrm{KK}$ & Date & $09 / 08 / 98$ \\
\hline Calculated by & SY & Date & $09 / 10 / 98$ \\
\hline Checked by & $\mathrm{AP}$ & Date & $09 / 11 / 98$ \\
\hline
\end{tabular}

\section{INITIAL CONDITION OF SPECIMEN}

Diameter (d)

Sample Area (A)

Length (L)

Weight Before

Wet Density

Dry Density

$\frac{2.415}{2.30}+\frac{4.58}{344.5}+{ }_{\text {in }}^{\text {in }}$

124.5

118.4 pef pct
Container No.

Wt. Wet Soil+Container(gms)

Wt. Dry Soil+Container(gms)

Wt. Container (gms)

Moisture, (\%)

$\begin{array}{r}\text { Before } \\ \hline \hline-\frac{214.41}{211.02} \\ \hline-\frac{145.17}{5.1}\end{array}$

\section{IEST RESULTS}

\begin{tabular}{|c|cccccccc}
\hline $\begin{array}{c}\text { Time } \\
(\mathrm{min})\end{array}$ & $\begin{array}{c}\text { Flow Rdg } \\
(\mathrm{cm})\end{array}$ & $\begin{array}{c}\text { Burette } \\
\text { Factor }\end{array}$ & $\begin{array}{c}\mathrm{Q} \\
(\mathrm{cc})\end{array}$ & $\begin{array}{c}\text { Head, } \mathrm{h} \\
(\mathrm{psi})\end{array}$ & $\begin{array}{c}\mathrm{h} / \mathrm{L} \\
\mathrm{Q} / \mathrm{t}\end{array}$ \\
\hline 0 & 0.2 & 0.486 & 0.0 & 3.0 & 36.1 & 0.000000 \\
\hline 1 & 4.3 & 0.486 & 2.0 & 3.0 & 36.1 & 0.033210 \\
\hline 3 & 13.2 & 0.486 & 6.3 & 3.0 & 36.1 & 0.036045 \\
\hline 4 & 18.1 & 0.486 & 8.7 & 3.0 & 36.1 & 0.039690 \\
\hline 5 & 23.0 & 0.486 & 11.1 & 3.0 & 36.1 & 0.039690 \\
\hline 5.5 & 25.2 & 0.486 & 12.2 & 3.0 & 36.1 & 0.035640 \\
\hline
\end{tabular}

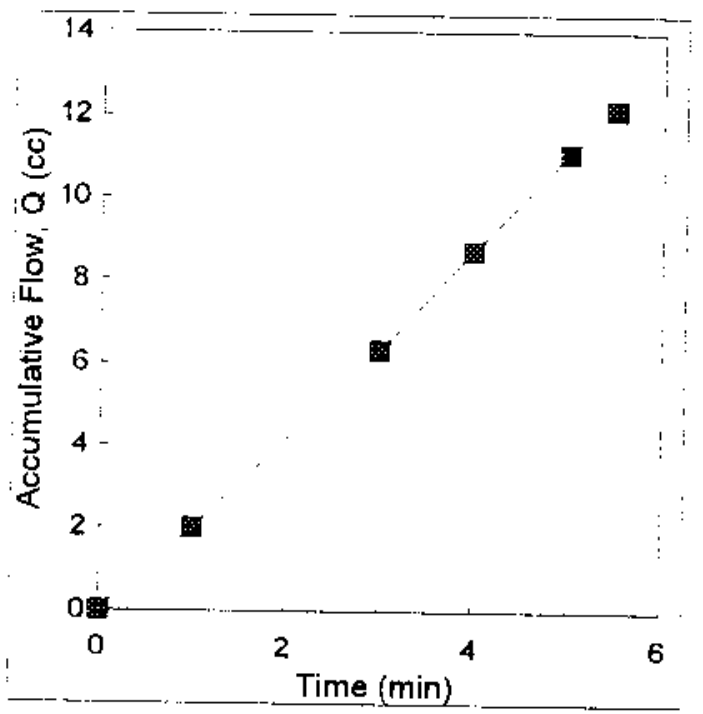

Hydraulic Conductivity (cm/sec): $3.59 \mathrm{E}-05$ 
FLEXIBLE WALL HYDRAULIC CONDUCTIVITY TEST

ASTM D5084

Project Name:

Project No.

Boring No:

Sample No.:

Soil Description:

Test Condition:
CAU 342 Mercury FTP

774729.03020300

FTP00102 Depth: N/A feet

Pate Brown Clayey Sand

Brass Tube

Confining Pressure =

$\begin{array}{rr}\text { Tested by } & \text { KK } \\ \text { Calculated by } & \text { SY } \\ \text { Checked by } & \text { AP }\end{array}$

Date $09 / 07 / 98$

Date $09 / 10 / 98$

Date $09 / 11 / 98$

\section{INITIAL CONDITION OF SPECIMEN}

Diameter (d)

Sample Area (A)

Length (L)

Weight Before

$\frac{\frac{2.415}{4.58}}{2.20} \frac{308.82}{2}-{ }_{\text {in }}^{\text {in }}$

Wet Density

Dry Density

116.7
110.4

Container No.

Wt. Wet Soil+Container(gms)

Wt. Dry Soil+Container(gms)

Wt. Container (gms)

Moisture, (\%)

\begin{tabular}{|c|c|}
\hline Before & After \\
\hline 634.26 & 385.86 \\
\hline 628.28 & 339.82 \\
\hline 522.21 & 50.18 \\
\hline 5.6 & 15.9 \\
\hline
\end{tabular}

\section{TEST RESULTS}

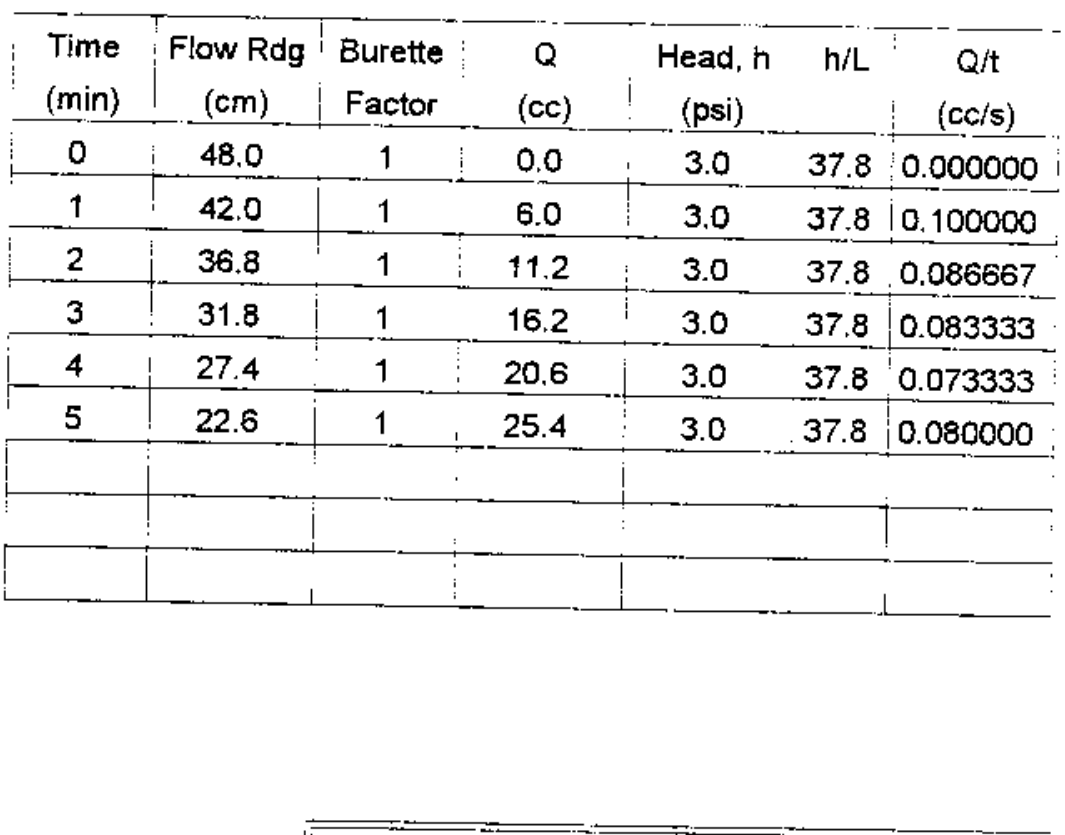

Hydraulic Conductivity (cm/sec): $7.07 \mathrm{E}-05$ 


\section{FLEXIBLE WALL HYDRAULIC CONDUCTIVITY TEST ASTM D5084}

Project Name: $\quad$ CAU 342 Mercury FTP

Project No: $\quad 774729.03020300$

Boring No:

Sample No.:

Soil Description:

Test Condition:
FTP00110 Depth: N/A feet

Pale Brown Silty Sand w/ gravel

Brass Tube

Confining Pressure $=$

$\begin{array}{rr}\text { Tested by } & K K \\ \text { Calculated by } & \text { SY } \\ \text { Checked by } & \text { AP }\end{array}$

$\begin{array}{ll}\text { Date } & \frac{09 / 07 / 98}{0 \text { Date }} \\ \text { Date } & 09 / 10 / 98 \\ 09 / 11 / 98\end{array}$

\section{INITLAL CONDITION OF SPECIMEN}

Diameter (d)

Sample Area (A)

Length $(L)$

Weight Before

Wet Density

Dry Density

\begin{tabular}{cc}
2.415 & in \\
\hline 4.58 & in $^{2}$ \\
\hline 3.60 & in \\
\hline 513.19 & ${ }^{9}$
\end{tabular}

118.5

112.8 pcf pef
Container No.

Wt. Wet Soil+Container(gms) Wt. Dry Soil+Container(gms) Wt. Container (gms)

Moisture, (\%)

$\begin{array}{r}\multicolumn{1}{c}{\text { Before }} \\ \hline 689.22 \\ \hline 684.84 \\ \hline 598.48 \\ \hline 5.1 \\ \hline\end{array}$

\section{TEST RESULTS}

\begin{tabular}{|c|c|ccccccc}
\hline $\begin{array}{c}\text { Time } \\
(\mathrm{min})\end{array}$ & $\begin{array}{c}\text { Flow Rdg } \\
(\mathrm{cm})\end{array}$ & $\begin{array}{c}\text { Furette } \\
\text { Factor }\end{array}$ & $\begin{array}{c}Q \\
(\mathrm{cc})\end{array}$ & $\begin{array}{c}\text { Head, h } \\
(\mathrm{psi})\end{array}$ & $\mathrm{h} / \mathrm{L}$ & $\begin{array}{c}\text { Q/t } \\
(\mathrm{cc} / \mathrm{s})\end{array}$ \\
\hline 0 & 45.5 & 1 & 0.0 & 1.0 & 7.69 & 0.0000000 \\
\hline 1 & 38.4 & 1 & 7.1 & 1.0 & 7.69 & 0.118333 \\
\hline 2 & 33.0 & 1 & 12.5 & 1.0 & 7.69 & 0.090000 \\
\hline 3 & 28.0 & 1 & 17.5 & 1.0 & 7.69 & 0.083333 \\
\hline 5 & 19.5 & 1 & 26.0 & 1.0 & 7.69 & 0.070833 \\
\hline 8 & 8.0 & 1 & 37.5 & 1.0 & 7.69 & 0.063889 \\
\hline & & & & & & \\
\hline & & & & & & & \\
\hline & & & & & & & \\
\hline
\end{tabular}

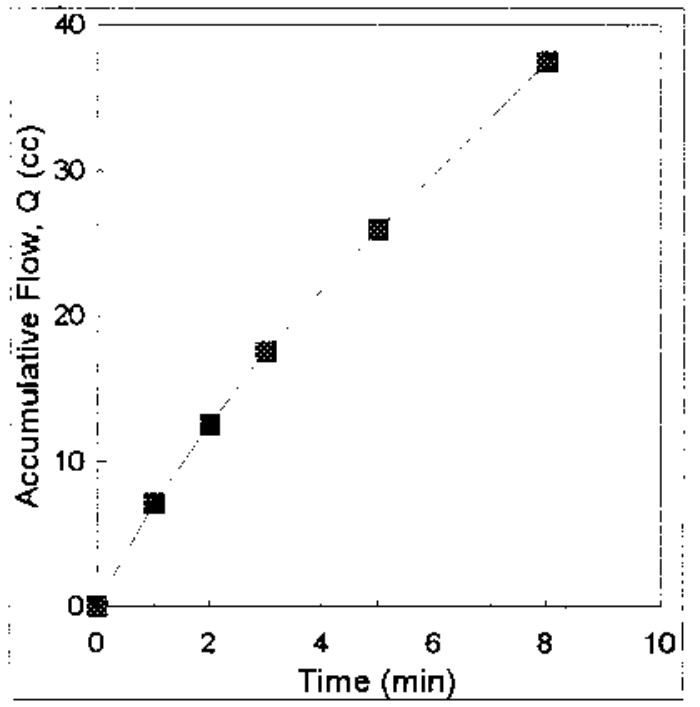


FLEXIBLE WALL HYDRAULIC CONDUCTIVITY TEST

ASTM D5084

Project Name: $\quad$ CAU 342 Mercury FTP

Project No: $\quad 774729.03020300$

Boring No:

Sample No.:

Soil Description:

Test Condition:
FTP00118 Depth: N/A feet

Pale Brown Silty Sand w/ gravel

Brass Tube

Confining Pressure $=$

5 PS!

$\begin{array}{rr}\text { Tested by } & \text { KK } \\ \text { Calculated by } & \text { SY } \\ \text { Checked by } & \text { AP }\end{array}$

$\begin{array}{ll}\text { Date } & -\frac{09 / 07 / 98}{09 / 10 / 98} \\ \text { Date } & -09 / 11 / 98 \\ \text { Date } & -09 / 11 / 2\end{array}$

\section{INITIAL CONDITION OF SPECIMEN}

Diameter (d)

Sample Area (A)

Length (L)

Weight Before

Wet Density

Dry Density

$\frac{2.415}{4.58}$
$\frac{3.10}{457.09}$${ }^{\text {in }}{ }^{2}$

122.6

114.3 pcf pef
Container No.

Wt. Wet Soil+Container(gms)

Wt. Dry Soil+Container(gms)

Wt. Container (gms)

Moisture, $(\%)$

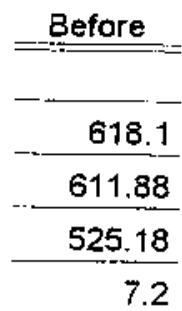

\section{TEST RESULTS}

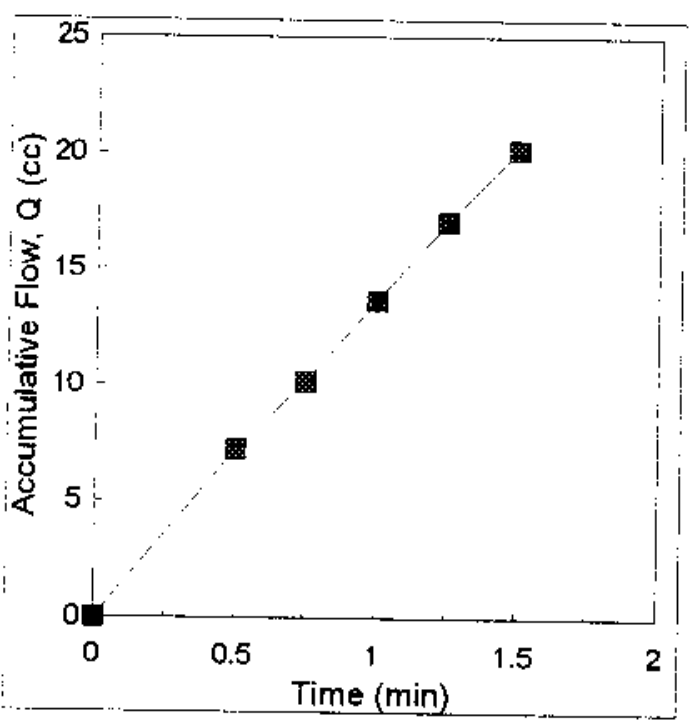

\begin{tabular}{|c|c|c|c|ccc|c}
\hline $\begin{array}{c}\text { Time } \\
(\mathrm{min})\end{array}$ & $\begin{array}{c}\text { Flow Rdg } \\
(\mathrm{cm})\end{array}$ & $\begin{array}{c}\text { Burette } \\
\text { Factor }\end{array}$ & $\begin{array}{c}\mathrm{Q} \\
(\mathrm{cc})\end{array}$ & $\begin{array}{c}\text { Head, } \mathrm{h} \\
\text { (psi) }\end{array}$ & $\mathrm{h} / \mathrm{L}$ & $\begin{array}{c}\mathrm{Q} / \mathrm{t} \\
(\mathrm{cc} / \mathrm{s})\end{array}$ \\
\hline 0 & 2.0 & 0.474 & 0.0 & 1.0 & 8.93 & 0.000000 \\
\hline 0.5 & 17.2 & 0.474 & 7.2 & 1.0 & 8.93 & 0.240160 \\
\hline 0.75 & 23.4 & 0.474 & 10.1 & 1.0 & 8.93 & 0.195920 \\
\hline 1 & 30.9 & 0.474 & 13.7 & 1.0 & 8.93 & 0.237000 \\
\hline 1.25 & 38.0 & 0.474 & 17.1 & 1.0 & 8.93 & 0.224360 \\
\hline 1.5 & 44.6 & 0.474 & 20.2 & 1.0 & 8.93 & 0.208560 \\
\hline & & & & & & \\
\hline & & & & & & \\
\hline
\end{tabular}




\section{FLEXIBLE WALL HYDRAULIC CONDUCTIVITY TEST \\ ASTM D5084}

Project Name: $\quad$ CAU 342 Mercury FTP

Project No: $\quad 774729.03020300$

Boring No:

Sample No:

Soil Description:

Test Condition:
FTP00148

Depth: N/A feet

Pale Brown Clayey Sand

Brass Tube

Confining Pressure $=$

$\begin{array}{rr}\text { Tested by } & \text { KK } \\ \text { Calculated by } & \text { SY } \\ \text { Checked by } & \text { AP }\end{array}$

\begin{tabular}{ll} 
Date & $09 / 07 / 98$ \\
Date & $09 / 10 / 98$ \\
Date & $09 / 11 / 98$ \\
\hline
\end{tabular}

\section{INITIAL CONDITION OF SPECIMEN}

Diameter (d)

Sample Area (A)

Length (L)

Weight Before

Wet Density

Dry Density

\begin{tabular}{rl}
2.415 & in \\
\hline 4.58 & in $^{2}$ \\
\hline 1.80 & in \\
\hline 288.42 & 9
\end{tabular}

133.2 129.5 pcf pcf
Container No.

Wt. Wet Soil+Container(gms)

Wt. Dry Soil+Container(gms)

Wt. Container (gms)

Moisture, (\%)

\begin{tabular}{|c|c|}
\hline Before & After \\
\hline 267.73 & 348.15 \\
\hline 264.37 & 320.51 \\
\hline 145.17 & 52.85 \\
\hline 2.8 & 10.3 \\
\hline
\end{tabular}

\section{TEST RESULTS}

\begin{tabular}{|c|c|c|c|c|c|c}
\hline $\begin{array}{c}\text { Time } \\
(\mathrm{min})\end{array}$ & $\begin{array}{c}\text { Fiow Rdg } \\
(\mathrm{cm})\end{array}$ & $\begin{array}{c}\text { Burette } \\
\text { Factor }\end{array}$ & $\begin{array}{c}\mathrm{Q} \\
(\mathrm{cc})\end{array}$ & $\begin{array}{c}\text { Head, h } \\
(\mathrm{psi})\end{array}$ & $\mathrm{h} / \mathrm{L}$ & $\begin{array}{c}\mathrm{Q} / \mathrm{t} \\
(\mathrm{cc} / \mathrm{s})\end{array}$ \\
\hline 0 & 4.7 & 2.449 & 0.0 & 3.0 & 46.2 & 0.000000 \\
\hline 6 & 8.5 & 2.449 & 9.3 & 3.0 & 46.2 & 0.025851 \\
\hline 14 & 12.5 & 2.449 & 19.1 & 3.0 & 46.2 & 0.020408 \\
\hline 21 & 16.0 & 2.449 & 27.7 & 3.0 & 46.2 & 0.020408 \\
\hline 30 & 20.2 & 2.449 & 38.0 & 3.0 & 46.2 & 0.019048 \\
\hline 44 & 26.5 & 2.449 & 53.4 & 3.0 & 46.2 & 0.018368 \\
\hline & & & & & & \\
\hline & & & & & & \\
\hline & & & & & & \\
\hline
\end{tabular}

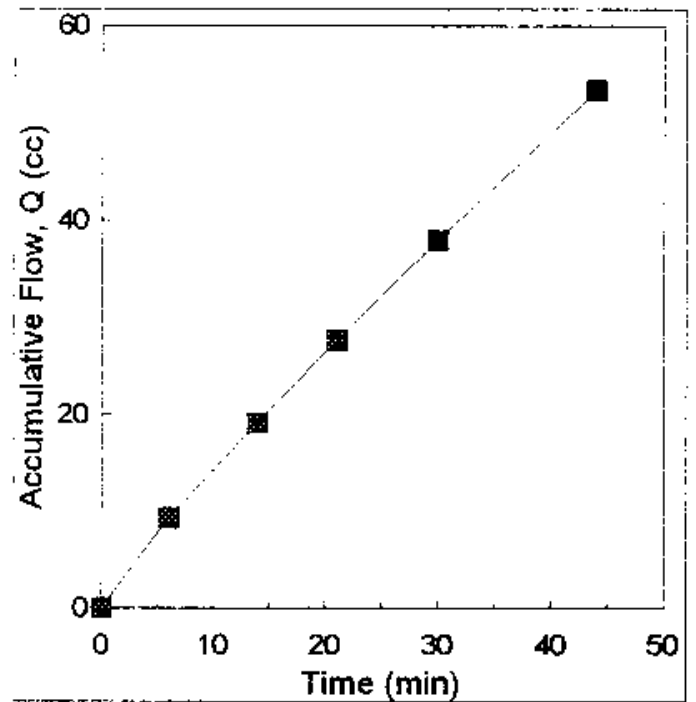




\section{FLEXIBLE WALL HYDRAULIC CONDUCTIVITY TEST \\ ASTM D5084}

Project Name:

Project No::

Boring No.:

Sample No:

Soil Description:

Test Condition:
CAU 342 Mercury FTP

774729.03020300

FTP00158

Depth: N/A feet

Pale Brown Silty Sand

Brass Tube

Confining Pressure =

\begin{tabular}{rr} 
Tested by & KK \\
Calculated by & SY \\
Checked by & AP \\
\cline { 2 - 2 }
\end{tabular}

Date 09/08/98

Date $\quad 09 / 10 / 98$

Date $09 / 11 / 98$

\section{INITIAL CONDITION OF SPECIMEN}

Diameter $(d)$

Sample Area (A)

Length $(L)$

Weight Before

Wet Density

Dry Density

$\frac{2.415}{4.58} \frac{\text { in }}{3.20}$ in

pcf pct

\begin{tabular}{rr}
121.1 & pcf \\
\hline 19.1 & pct
\end{tabular}

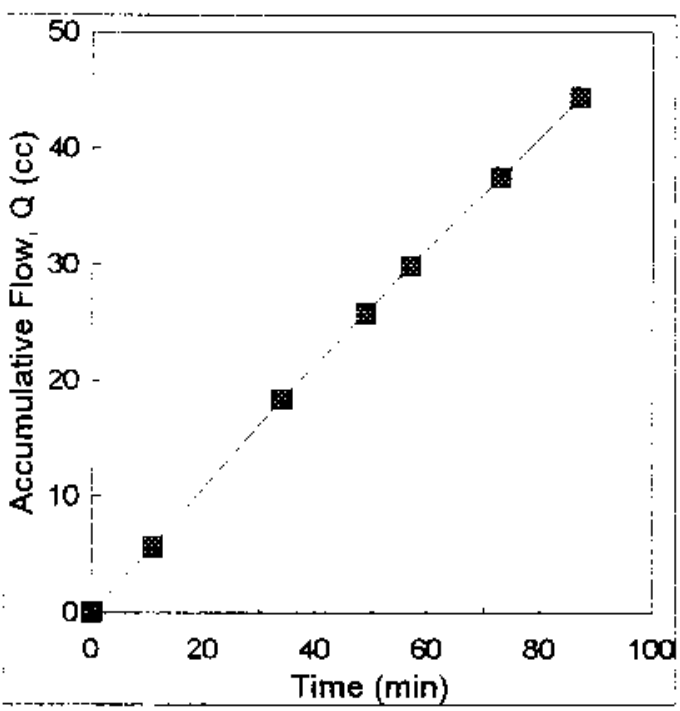

\section{TEST RESULTS}

Container No.

Wt. Wet Soil+Container(gms)

Wt. Dry Soil+Container(gms)

Wt. Container (gms)

Moisture, (\%)

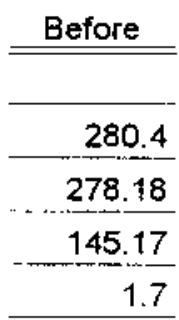

\begin{tabular}{|c|cc:c|c|c|c}
\hline $\begin{array}{c}\text { Time } \\
(\mathrm{min})\end{array}$ & $\begin{array}{c}\text { Flow Rdg } \\
(\mathrm{cm})\end{array}$ & $\begin{array}{c}\text { Burette } \\
\text { Factor }\end{array}$ & $\begin{array}{c}\mathrm{Q} \\
(\mathrm{cc})\end{array}$ & $\begin{array}{c}\text { Head, h } \\
(\mathrm{psi})\end{array}$ & $\mathrm{h} / \mathrm{L}$ & $\begin{array}{c}\mathrm{Q} / \mathrm{t} \\
(\mathrm{cc} / \mathrm{s})\end{array}$ \\
\hline 0 & 4.7 & 2.388 & 0.0 & 3.0 & 26 & 0.000000 \\
\hline 11 & 7.1 & 2.388 & 5.7 & 3.0 & 26 & 0.008684 \\
\hline 34 & 12.4 & 2.388 & 18.4 & 3.0 & 26 & 0.009171 \\
\hline 49 & 15.5 & 2.388 & 25.8 & 3.0 & 26 & 0.008225 \\
\hline 57 & 17.2 & 2.388 & 29.9 & 3.0 & 26 & 0.008458 \\
\hline 73 & 20.4 & 2.388 & 37.5 & 3.0 & 26 & 0.007960 \\
\hline 87 & 23.3 & 2.388 & 44.4 & 3.0 & 26 & 0.008244 \\
\hline & & & & & & \\
\hline
\end{tabular}




\section{FLEXIBLE WALL HYDRAULIC CONDUCTMITY TEST \\ ASTM D5084}

$\begin{array}{ll}\text { Project Name: } & \text { CAU } 342 \text { Mercury FTP } \\ \text { Project No:: } & 774729.03020300 \\ \text { Boring No.: } & \text { FTP00159 Depth: N/A feet } \\ \text { Sample No.: } & \text { Pale Brown Sandy Silt } \\ \text { Soil Description: } & \text { Brass Tube } \\ \text { Test Condition: } & \text { Confining Pressure }=\quad 5 \text { PSI }\end{array}$

\begin{tabular}{rr} 
Tested by & KK \\
\hline Calculated by & SY \\
Checked by & AP
\end{tabular}

$\begin{array}{ll}\text { Date } & 09 / 08 / 98 \\ \text { Date } & 09 / 10 / 98 \\ \text { Date } \quad 09 / 11 / 98\end{array}$

\section{INITIAL CONDITION OF SPECIMEN}

Diameter (d)

Sample Area (A)

Length (L)

Weight Before

Wet Density

Dry Density
2.415

\begin{tabular}{rl}
2.415 & in \\
\hline 4.58 & in ${ }^{2}$ \\
\hline 1.80 & in \\
\hline 257.77 & 9
\end{tabular}

119.0

114.4 pef pcf
Container No.

Wt. Wet Soil+Container(gms)

Wt. Dry Soil+Container(gms)

Wt. Container (gms)

Moisture, (\%)

\begin{tabular}{|c|c|}
\hline Before & After \\
\hline 598.85 & 310.16 \\
\hline 595.87 & 276.28 \\
\hline 522.18 & 27.34 \\
\hline 4.0 & 13.6 \\
\hline
\end{tabular}

\section{TESTRESULTS}

\begin{tabular}{|c|c|c|c|c|c|c|}
\hline $\begin{array}{c}\text { Time } \\
\text { (min) }\end{array}$ & $\begin{array}{c}\text { Flow Rdg } \\
(\mathrm{cm})\end{array}$ & $\begin{array}{l}\text { Burette } \\
\text { Factor }\end{array}$ & $\begin{array}{c}\mathrm{Q} \\
(\mathrm{cc})\end{array}$ & $\begin{array}{c}\text { Head, h } \\
\text { (psi) }\end{array}$ & $\begin{array}{c}\mathrm{Q} / \mathrm{t} / \mathrm{L} \\
(\mathrm{cc} / \mathrm{s})\end{array}$ \\
\hline 13 & 42.0 & 1 & 0.0 & 3.0 & 46.2 & 0.000000 \\
\hline 28 & 36.8 & 1 & 5.2 & 3.0 & 46.2 & 0.006667 \\
\hline 81 & 15.6 & 1 & 26.4 & 3.0 & 46.2 & 0.005063 \\
\hline 89 & 13.0 & 1 & 29.0 & 3.0 & 46.2 & 0.005417 \\
\hline 104 & 9.2 & 1 & 32.8 & 3.0 & 46.2 & 0.004222 \\
\hline 119 & 5.0 & 1 & 37.0 & 3.0 & 46.2 & 0.004667 \\
\hline & & & & & & \\
\hline
\end{tabular}

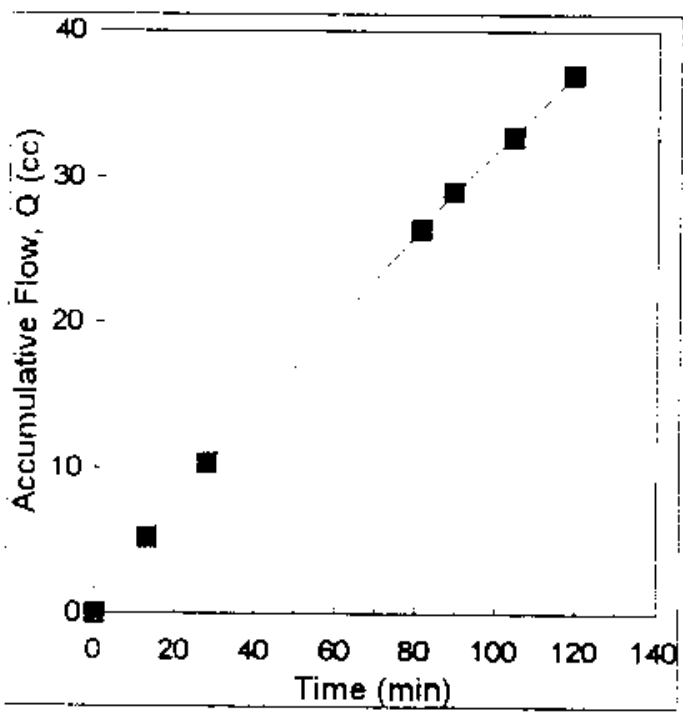


Appendix D

Cost Estimates 


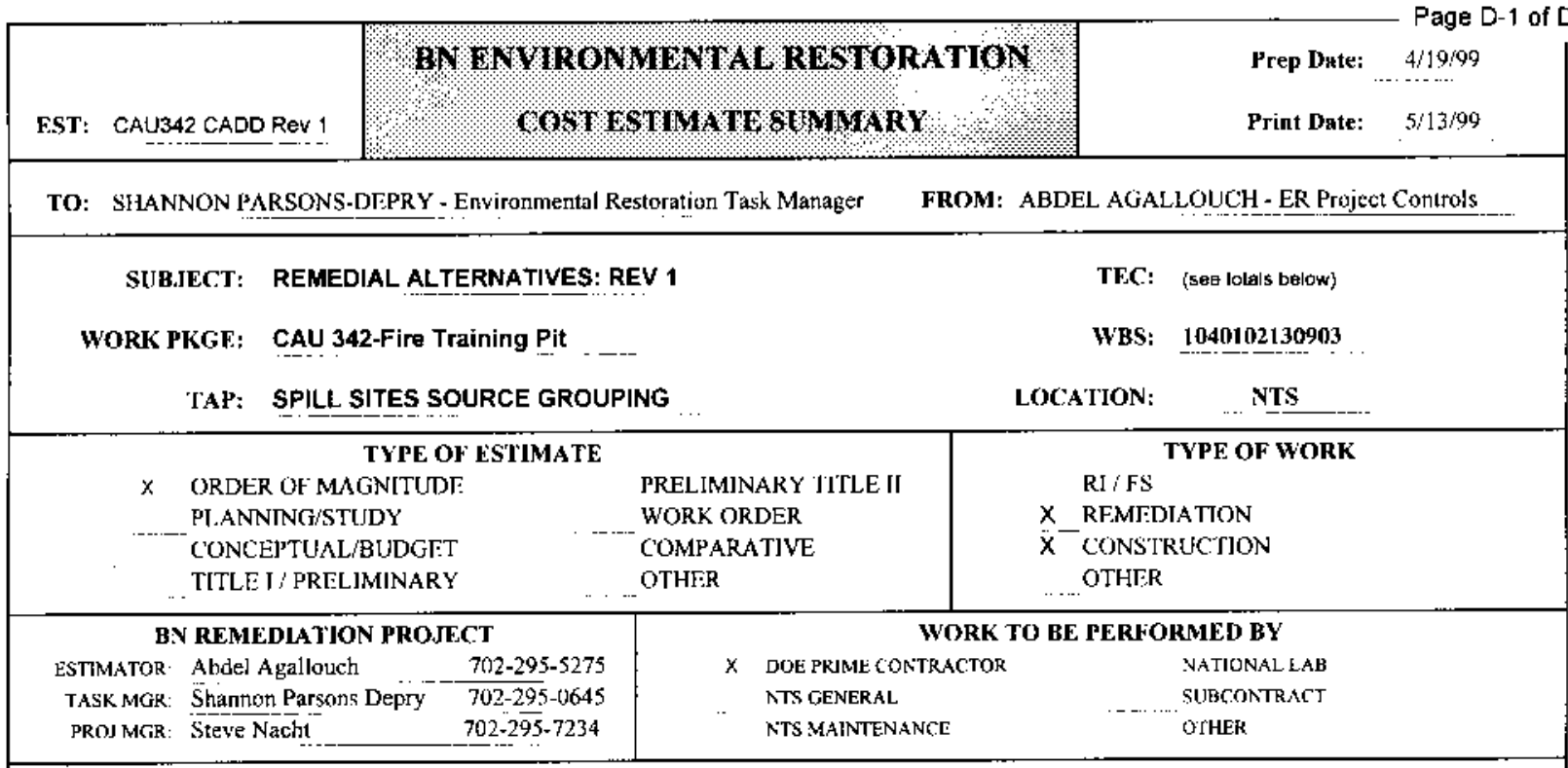

\section{STATEMENT OF WORK:}

This estimate has been prepared to provide remedial alternative costs for the closure of Corrective Action Unit (CAU) 342 , an environmental restoration site listed in the Federal Facilities and Consent Order (FFACO). CAU 342 is specificatly described as the Area 23 Fire Training Pit . Four alternatives will be evaluated for closure of the site: I ) No Further action no associated costs or administrative controls, II) Closure by administrative controls, partial cxcavation and drilling, III) Closure by bioremediation and partial excavation, and IV) Closure by gas vapor monitoring and partial excavation. This estimate will be used to identify the most cost effective alternative for closure of the site while being protective of human health and the environment. Total estimated costs are intended for comparative analysis of remedial field work and field management only. Costs for project management, plan preparation, project support, or other overhead functions are not included.

SCOPE

Provide site closure using one of the following alternatives:

I) NO FURTHER ACTION -NO ASSOCIATED COSTS OR ADMINISTRATIVE CONTROLS

II) PARTIAL EXCAVATION AND DRILLING

III) BIOREMIDIATION AND PARTIAL EXCAVATION

IV) PARTIAL EXCAVATION AND GAS VAPOR MONITORING

\section{BASIS OF ESTLMATE AND ASSUMPTLONS}

\section{Alternative U: Partial excavation and drilling}

- The total volume of excavation is approximately $2100 \mathrm{CY}$, including a $20 \%$ expansion factor and will be disposed of at the Area 6 TPH landfill. Assume clean fill material will be used from the stockpile of material at decon pond in area 6 .

- Process and transport of $150 \mathrm{CY}$ of pea gravel from batch plant to the site

- The excavation depths will range from $1 \mathrm{ft}$ to $5 \mathrm{ft}$

- Assume 6 loads/day (is) $20 \mathrm{CY} /$ load for a total of $120 \mathrm{CY} /$ day, will be excavated, disposed of and backfilled.

- Assume excavation will require 17 days

- Backfill material for excavated areas will be compacted using a backhoe/loader.

- Fence line survey for use restriction document will be required.

- Labor costs are based on a $10 \mathrm{hr}$ day, 4 day week schedule.

- Assume no hazardous material will be encountered during the excavation operations.

- 320 feet deep wells will be drilled at different locations for a total of 60 linear feet. Assume drilling of the wells will require 2 days for mobe and demobe, 4 days of drilling

- The majority of soil with TPH concentrations greater than $10,000 \mathrm{mg} / \mathrm{Kg}$ will be excavated using an $81 / 2 \mathrm{ft}$ diameter auger.

- Assume 20 samples will be, collected and analyzed for TPH

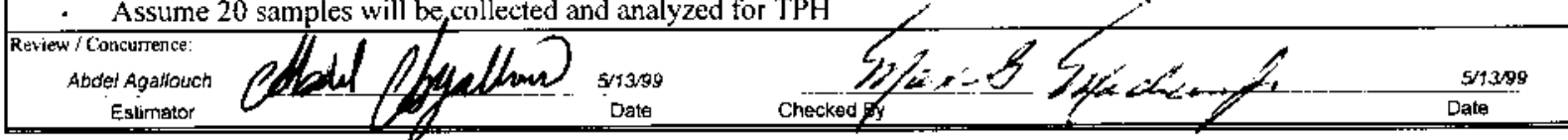




\section{Appendix E}

Bioassessment Report, Nevada Test Site, CAU 342 (Area 23 Mercury Fire Training Pit) 


\section{BIOASSESSMENT REPORT NEVADA TEST SITE CAU 342 (AREA 23 MERCURY FIRE TRAINING PIT)}

Prepared for:

IT CORPORATION

LAS VEGAS, NEVADA

Prepared by:

IT CORPORATION 312 DIRECTORS DRIVE KNOXVILLE, TENNESSEE 37923

IT PROJECT NO. 774729

MAY 1999

REVISION 1 
List of Tables

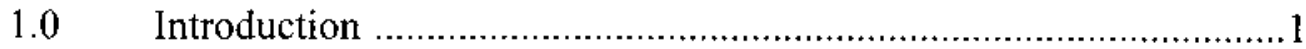

$2.0 \quad$ Bioassessment Test Results .......................................................2

$2.1 \quad \mathrm{pH}$ and Soil Moisture ................................................2

2.2 Background Nutrient Concentrations .................................. 3

2.3 Microbial Enumerations .................................................. 3

2.4 Microbial Stimulation Test........................................... 4

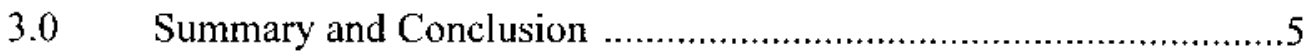

Tables 
$1 \quad$ Nutrient Content, and $\mathrm{pH}$, of Site Samples. . . . . . . . . . . .

2 Enumeration of the Microbial Population Density in Site Samples. . . . . . .8

3 Stimulation of the Growth of Site Microbes by Enhanced Oxygenation. . . . .9 and Nutrient Augmentation 


\subsection{Introduction}

IT Corporation was contracted to conduct a site bioassessment on samples collected from the Nevada Test Site, Corrective Action Unit 342 (Area 23 Mercury Fire 'Training Pit). The Biotechnology Applications Center received eight soil samples on June 26, 1998. The samples were collected June 1998. In order to investigate the feasibility of bioremediation at the Fire Training Pit (FTP), a bioassessment was performed on eight site soil samples.

Bioremediation is an environmental remediation tool that uses bacteria to oxidize a wide variety of wastes. Bacteria can transform most natural and man-made organic compounds given appropriate environmental conditions and an adequate acclimation period. The biological conversion of organic compounds into biomass, carbon dioxide, and water makes bioremediation an attractive remedial alternative.

The FTP was used from the early 1960s through the early 1990s for fire suppression training exercises. Fires were ignited using off-specification or rust-contaminated fuels; various firesuppressant chemicals were used to extinguish the fires. The chemicals of potential concern (COPCs) consist mainly of hydrocarbons and possibly other volatile organic compounds, semivolatile organic compounds, metals, and polychlorinated biphenyls. In addition to regular training exercises, special burns were occasionally conducted to test cables or other materials. These special burns may have resulted in the release of other contaminants such as dioxins and furans.

The surface and subsurface soils in the FTP have likely been impacted by hydrocarbons and other COPCs associated with burn activities and training exercises in the area. The COPCs may have been redistributed across the surface of the FTP through regarding activities and previous cleanup activities. Subsurface COPCs would be a result of direct release of hydrocarbon fucls to the soil and subsequent vertical migration through natural processes or the application of water used during fire fighting exercises. Subsurface contamination in the burn pit area reached 20 feet below ground surface (bgs) and reached approximately 40-50 feet bgs in the Aboveground Storage Tanks area. Groundwater impact is unlikely because depth to groundwater is greater than 800 feet and the environmental conditions at the site (i.e., arid climate, high evapotransporation rate, low subsurface permeabilities) are not conducive to downward migration. 
Bioventing is a common method of bioremediation which may be applicable for impacted vadose zone soils found on site. Bioventing is the in situ biological treatment of contaminated vadose zone soil. During bioventing, remediation is promoted by supplying oxygen to the subsurface using blowers or vacuum pumps. Bioventing can effectively treat any biodegradable compound, if bacteria are present in the soil with the metabolic capability to biodegrade the target compounds. In the case of petroleum products such as gasoline, jet fuel, diesel, and heating oils, bacteria are nearly always present but they may not be very active due to lack of oxygen, extreme $\mathrm{pH}$, lack of nutrients, lack of moisture, or cold temperature.

\subsection{Bioassessment Test Results}

This bioassessment is a series of tests designed to evaluate the physical, chemical, and microbiological characteristics of a site. The bioassessment consists of nutrient determinations, $\mathrm{pH}$, microbial population density, and the ability of the microbial populations to grow under enhanced environmental conditions. Understanding and controlling these parameters is critical for designing and executing a successful soil treatment system.

\section{$2.1 \quad p H$ and Soil Moisture}

The optimal $\mathrm{pH}$ for effective bioremediation is in the range of 6 to 8 . A pH outside of this range may negatively affect microbial metabolism and contaminant biodegradation. Results of the laboratory $\mathrm{pH}$ measurements are reported in 'Table 1 . The $\mathrm{pH}$ of the soil samples range from 8.1 to 9.3. If this $\mathrm{pH}$ range is a result of natural alkaline soil conditions common in deserts, biodegradation may proceed with little impact from the high $\mathrm{pH}$. If the $\mathrm{pH}$ has been raised from neutral by man-made changes, microbiological activity may be impaired. Petroleum degradation often results in the formation of organic acids that depress $\mathrm{pH}$. Thus, the slightly alkaline $\mathrm{pH}$ is not expected to have long term detrimental effects on treatment.

The moisture content of the soil samples ranged from 4 to 12 percent (weight to weight). The samples were characterized as fine soil containing rocks. 


\subsection{Background Nutrient Concentrations}

Nutrients essential for bioremediation are nitrogen, as ammonium, and phosphorous, as orthophosphate. The existing nutrient concentrations in all samples were defined to determine the need for nutrient additions. Results of the analyses for these inorganic nutrients are shown in Table 1. The ammonium concentrations in the eight soil samples were below the detection limit $(4.0 \mathrm{mg} / \mathrm{K})$ in all but two of the samples. Sample B5-14-15M had a high ammonium concentration of $25 \mathrm{mg} / \mathrm{Kg}$ and sample FTP00093 had a low ammonium value of $5.4 \mathrm{mg} / \mathrm{K}$. This suggests that the lack of ammonium in most of these soil samples may limit the rate and effectiveness of remediation. Phosphate concentrations in the soil samples range from 33 to $210 \mathrm{mg} / \mathrm{Kg}$. Phosphate frequently combines with naturally occurring cations to form insoluble minerals. This means that even if phosphate levels are high, biological availability can still be low. In the FTP samples the phosphate content of the soil is low to moderate. Nutrient additions (particularly fixed nitrogen) may be required to avoid nutrient limited biodegradation during bioremediation.

\subsection{Microbial Enumerations}

In situ treatment requires the presence of hydrocarbon-degrading bacteria. To determine if appropriate bacteria are present, bacteria are quantified according to two categories. The first category includes heterotrophic bacteria, defined as those bacteria capable of growing on dilute, solidified nutrient medium. Heterotrophs represent a very general class of bacteria that are typically abundant in soil and groundwater. Quantification of this category provides a measure of the overall size and vigor of the bacterial population.

The second category includes hydrocarbon-degrading bacteria. These bacteria are quantified after growing in an environment where petroleum hydrocarbons are the only available carbon (or food) source. In this study the petroleum hydrocarbon used as the carbon source was diesel. This test determines if the bacterial population has adapted to the contaminant present in the soil samples.

The heterotrophic population ranged from less than 10 colony -forming units per gram of dry soil (CFU/g) to $630,000 \mathrm{CFU} / \mathrm{g}$ after 10 days of incubation. Hydrocarbon-degrading microbial population size ranged from less than $10 \mathrm{CFU} / \mathrm{g}$ to $60,000 \mathrm{CFU} / \mathrm{g}$ over the same length of time. 
The results indicate that a viable microbial population exists on site. Native population sizes are listed on Table 2.

\subsection{Microbial Stimulation Test}

A microbial stimulation test was performed to determine if enhanced in situ conditions will stimulate growth of indigenous bacteria. This test involves introducing oxygen or oxygen plus nutrients to soil slurries created from the soil samples. The results determine if oxygen will stimulate activity, and if nutrients provide an additional benefit. A positive response is indicated by a five-fold or greater change in microbial density.

In almost all samples bacterial densities for the heterotrophic population in the FTP soil samples increased by 53 -fold to 152-fold after oxygenation. The exceptions were samples B14-29-30M, FTP00159, and FTP00102 which exhibited no increase upon oxygenation. Oxygenation with nutrient addition caused an additional increase in only two samples; B8-14-15M by 2441 -fold and FTP00110 by 200 -fold (Table 3). The hydrocarbon degraders increased by 2 -fold to 570 fold with oxygenation and 38-fold to 3,673-fold with oxygenation and nutrient addition. Sample B14-29-30M did not respond to oxygenation nor oxygenation with nutrient addition. Samples FTP00159 and FTP00102 which only showed a slight increase upon oxygenation, showed no appreciable increase upon oxygenation with nutrient addition.

The heterotrophic population that increased with oxygenation showed additional increases upon oxygenation with nutrient addition in only one sample, B8-14-15M. The hydrocarbon degrading population showed increases with oxygenation; however, oxygenation with nutrient addition resulted in a significant population increase in only one sample, B8-14-15M. This indicates that, in general, nutrients provided little additional benefit suggesting that residual nutrients were able to sustain microbial activity during the short duration of this test. Nutrient additions maybe required if the available level of residual nutrients fails to sustain biodegradation throughout the treatment process. The initial $\mathrm{pH}$ of the soil seemed to have no relationship to the response of the various samples in this test, suggesting that $\mathrm{pH}$ will not be detrimental to field scale biological treatment. 
The results of the bioassessment indicate that bioremediation is a feasible remedial option for the petroleum impacted soils through the use of bioventing. The results of the bioassessment are summarized below:

- Viable microbial populations exist at the site and appear to be well adapted to site conditions

- Heterotrophic populations and hydrocarbon degraders responded favorably to oxygenation but the benefits of oxygenation and nutrient addition were only significant in sample B8-14-15M. Nutrient addition to the vadose zone is not recommended until in , situ respiration rates decline.

- The optimal $\mathrm{pH}$ for microbial activity is between 6 and 8. The $\mathrm{pH}$ values for all of the site samples were above 8 . Although the $\mathrm{pH}$ values fall outside of the typical range for successful biodegradation, microbes adapted to alkaline desert soils appear capable of sustaining aerobic biodegradation.

- Phosphate levels are moderate and ammonia levels are less than the detection limit of $4 \mathrm{mg} / \mathrm{Kg}$ for almost all of the samples.

- Moisture levels were generally low and may limit biodegradation.

Bioventing is the in situ aeration of unsaturated (vadose zone) soil to stimulate aerobic biodegradation of organic contaminants. Bioventing is attractive for sites where soil cannot be excavated due to contaminant depth, volume of soil, or the presence of surface structures.

Bioventing can be operated in remote areas where there is no supplied electricity through the use of wind powered turbines or solar powered blowers.

Bioventing systems are aerated by injecting or extracting air from the treatment area. Bioventing wells are located throughout the contaminated soil and are slotted through the entire thickness of the contamination to effectively aerate the contaminated soil. Unlike soil vapor extraction, the 
introduction of air into the soil provides oxygen with very little volatilization of contaminants.

For air injection systems, volatile emissions are almost never observed at the ground surface.

The amount of air required for biological activity is far less than that required for conventional

Soil Vapor Extraction systems so the cost for equipment and energy is usually less and the requirement for air pollution control can be minimized or eliminated.

The soil at the FTP site is fairly dry. This could inhibit microbial activity. It is recommended that moisture be added at this site prior to and during bioventing. There are several mechanisms for the addition of water to the site soil, options include; irrigation and infiltration, injection of humidified air through the bioventing system, or pumping water into the soil through multiple small direct push points. Prior to bioventing an in situ respiration test should be performed to verify microbial activity at the site.

The parameters which are typically monitored quarterly or semiannually for bioventing are soil moisture content, inorganic nutrients, $\mathrm{pH}$, and microbial activity. Microbial activity must be maintained and can be monitored through in situ respiration testing. The soil being treated must be aerated on a regular basis in order to sustain microbial activity and biodegration. Nutrients may limit biodegradation eventually; however, bioventing should proceed without nutrient addition until evidence of low microbial respiration is observed. At that time nutrients can be added using IT's patented vapor phase nutrient delivery system or by injection of liquid nutrient solutions. 
Table 1

Nevada Test Site

Fire Training Pit

Nutrient Content, and pH, of Site Samples

IT Project No. 774729

\begin{tabular}{|c|c|c|c|c|c|}
\hline SAMPLE NO. & MATRIX & $\begin{array}{l}\text { AMMONIUM } \\
\qquad(\mathrm{ppm})^{2}\end{array}$ & $\begin{array}{c}\text { ORTHO- } \\
\text { PHOSPHATE } \\
\text { (ppm) }\end{array}$ & $\begin{array}{c}\% \text { SOIL } \\
\text { MOISTURE }\end{array}$ & pH \\
\hline B8-14-15M & $\begin{array}{c}\text { Fine Soil } \\
\text { Rocky }\end{array}$ & $4.0 \mathrm{U}^{\mathrm{b}}$ & 210 & 5.6 & 8.1 \\
\hline B14-29-30M & $\begin{array}{c}\text { Fine Soil } \\
\text { Rocky }\end{array}$ & $4.0 \mathrm{U}$ & 210 & 4.8 & 9.3 \\
\hline B5-14-15M & $\begin{array}{c}\text { Fine Soil } \\
\text { Rocky }\end{array}$ & 25 & 88 & 12 & 8.2 \\
\hline FTP00148 & $\begin{array}{l}\text { Fine Soil } \\
\text { Rocky }\end{array}$ & $4.0 \mathrm{U}$ & 120 & 5.3 & 9.1 \\
\hline FTP00159 & $\begin{array}{c}\text { Fine Soil } \\
\text { Rocky }\end{array}$ & $4.0 \mathrm{U}$ & 84 & 3.9 & 9.3 \\
\hline FTP00093 & $\begin{array}{c}\text { Fine Soil } \\
\text { Rocky }\end{array}$ & 5.4 & 33 & 5.2 & 8.7 \\
\hline FTP00102 & $\begin{array}{c}\text { Fine Soil } \\
\text { Rocky }\end{array}$ & $4.0 \mathrm{U}$ & 110 & 5.5 & 8.4 \\
\hline FTP00110 & $\begin{array}{c}\text { Fine Soil } \\
\text { Rocky }\end{array}$ & $4.0 \mathrm{U}$ & 87 & 6.4 & 9.3 \\
\hline
\end{tabular}

^ppm is $\mathbf{m g} / \mathrm{KG}$ for soil

${ }^{\mathrm{b}} \mathrm{U}=$ concentration below the detection limit 
Table 2

Nevada Test Site

Fire Training Pit

Enumeration of the Microbial Population Density of Site Samples

IT Project No: 774729

\begin{tabular}{|c|c|c|c|}
\hline SAMPLE NO. & MATRIX & $\begin{array}{c}\text { TOTAL } \\
\text { HETEROTROPHSa } \\
(\text { CFU/g) }\end{array}$ & $\begin{array}{c}\text { HYDROCARBON } \\
\text { DEGRADERS } \\
\text { (CFU/g) }\end{array}$ \\
\hline B8-14-15M & $\begin{array}{c}\text { Fine Soil } \\
\text { Rocky }\end{array}$ & $1.4 \times 10^{3}$ & $3.4 \times 10^{2}$ \\
\hline B14-29-30M & $\begin{array}{c}\text { Fine Soil } \\
\text { Rocky }\end{array}$ & $1.2 \times 10^{2}$ & $1.5 \times 10^{2}$ \\
\hline B5-14-15M & $\begin{array}{c}\text { Finc Soil } \\
\text { Rocky }\end{array}$ & $5.2 \times 10^{4}$ & $1.0 \times 10^{4}$ \\
\hline FTP00148 & $\begin{array}{c}\text { Fine Soil } \\
\text { Rocky }\end{array}$ & $8.3 \times 10^{2}$ & $5.7 \times 10^{2}$ \\
\hline FTP00159 & $\begin{array}{c}\text { Fine Soil } \\
\text { Rocky }\end{array}$ & $<1.0 \times 10^{1}$ & $<1.0 \times 10^{1}$ \\
\hline FTP00093 & $\begin{array}{l}\text { Fine Soil } \\
\text { Rocky }\end{array}$ & $1.9 \times 10^{3}$ & $3.2 \times 10^{1}$ \\
\hline FTP00102 & $\begin{array}{c}\text { Fine Soil } \\
\text { Rocky }\end{array}$ & $2.4 \times 10^{3}$ & $8.5 \times 10^{2}$ \\
\hline FTP00110 & $\begin{array}{c}\text { Fine Soil } \\
\text { Rocky }\end{array}$ & $6.3 \times 10^{5}$ & $6.0 \times 10^{4}$ \\
\hline
\end{tabular}

'I0 Day Incubation time before enumerations

'21 Day Incubation time before enumerations

'CFU/g, colony forming units per gram dry soil 
Table 3

Nevada Test Site Fire Training Pit

Stimulation of the Growth of Site Microbes by

Enhanced Oxygenation and Nutrient Augmentation

IT Project No. 774729

\begin{tabular}{|c|c|c|c|c|c|c|}
\hline & \multicolumn{3}{|c|}{ Heterotrophs (CFU/g) } & \multicolumn{3}{|c|}{ Hydrocarbon Degraders (CFU/g) } \\
\hline $\begin{array}{c}\text { SAMPLE } \\
\text { NO. }\end{array}$ & INITIAL & OXYGENa & $\begin{array}{c}\text { OXYGEN } \\
\text { AND } \\
\text { NUTRIENTS } b\end{array}$ & INITIAL & OXYGEN & $\begin{array}{c}\text { OXYGEN } \\
\text { AND } \\
\text { NUTRIENTS }\end{array}$ \\
\hline B8-14-15M & $4.3 \times 10^{4}$ & $2.3 \times 10^{6}$ & $1.1 \times 10^{8}$ & $4.6 \times 10^{4}$ & $7.6 \times 10^{6}$ & $1.7 \times 10^{8}$ \\
\hline B14-29-30M & $1.6 \times 10^{3}$ & $1.0 \times 10^{2}$ & $1.2 \times 10^{3}$ & $1.4 \times 10^{3}$ & $1.7 \times 10^{6}$ & $4.9 \times 10^{6}$ \\
\hline B5-14-15M & $3.6 \times 10^{5}$ & $1.4 \times 10^{7}$ & $1.2 \times 10^{7}$ & $8.4 \times 10^{4}$ & $1.7 \times 10^{6}$ & $4.9 \times 10^{6}$ \\
\hline FTP00148 & $2.6 \times 10^{3}$ & $1.4 \times 10^{5}$ & $8.2 \times 10^{4}$ & $1.3 \times 10^{3}$ & $8.5 \times 10^{4}$ & $5.0 \times 10^{4}$ \\
\hline FTP00159 & $<1.0 \times 10^{2}$ & $<1.0 \times 10^{2}$ & $<1.0 \times 10^{2}$ & $<1.0 \times 10^{2}$ & $2.0 \times 10^{2}$ & $<1.0 \times 10^{2}$ \\
\hline FTP00093 & $2.3 \times 10^{3}$ & $2.2 \times 10^{5}$ & $8.8 \times 10^{4}$ & $2 \times 10^{2}$ & $1.1 \times 10^{5}$ & $7.0 \times 10^{4}$ \\
\hline FTP00102 & $1.4 \times 10^{3}$ & $1.4 \times 10^{3}$ & $7.0 \times 10^{2}$ & $<1.0 \times 10^{2}$ & $8.0 \times 10^{2}$ & $1.0 \times 10^{2}$ \\
\hline FTP00110 & $6.8 \times 10^{5}$ & $9.0 \times 10^{7}$ & $1.4 \times 10^{6}$ & $2.0 \times 10^{5}$ & $4.0 \times 10^{7}$ & $1.5 \times 10^{7}$ \\
\hline
\end{tabular}

"The oxygenated treatment was vigorously shaken to provide oxygen to the microbes but no nutrients were added in addition to those present in the sample material.

boxygen and nutrient treatments are oxygenated and nutrient augmented with $100 \mathrm{ppm}$ of the microbial nutrient formulation Restore 375. 


\section{Appendix F}

Nevada Environmental Restoration Project Document Review Sheet 


\section{NEVADA ENVIRONMENTAL RESTORATION PROJECT}

DOCUMENT REVIEW SHEET

(Page 1 of 3 )

\begin{tabular}{|c|c|c|c|c|c|}
\hline \multicolumn{4}{|c|}{$\begin{array}{l}\text { 1. Document Title/Number: Corrective Action Decision Document for Corrective Action Unit 342: Area 23, } \\
\text { Mercury Fire Training Pit, Nevada Test Site, Nevada }\end{array}$} & \multicolumn{2}{|l|}{ 2. Document Date: February 1999} \\
\hline \multicolumn{4}{|c|}{ 3. Revision Number: 0} & \multicolumn{2}{|c|}{ 4. Originator/Organization: IT Corporation } \\
\hline \multicolumn{4}{|c|}{ 5. Responsible DOE/NV ERP Subproject Mgr.: Janet Appenzeller-Wing } & \multicolumn{2}{|l|}{ 6. Date Comments Due: } \\
\hline \multicolumn{6}{|c|}{ 7. Review Criteria: Full } \\
\hline \multicolumn{4}{|c|}{ 8. Reviewer/Organization/Phone No.: Paul Liebendorfer, NDEP, (775) 687-4670 } & \multicolumn{2}{|l|}{ 9. Reviewer's Signature: } \\
\hline $\begin{array}{l}\text { 10. Comment } \\
\text { Number/ } \\
\text { Location }\end{array}$ & 11. Type* & 12. Comment & \multicolumn{2}{|c|}{ 13. Comment Response } & $\begin{array}{l}14 . \\
\text { Accept }\end{array}$ \\
\hline $\begin{array}{l}\text { 1) Appendix A, } \\
\text { Page A-33, } \\
\text { Paragraph A.3.3 }\end{array}$ & M & $\begin{array}{l}\text { "...One sample (FTP00107) was analyzed for TCLP VOCs... } \\
\text { According to Table A.2-2, Page A-14, samples FTP 00089 and FTP } \\
00091 \text { (Borehole 1) should also have been analyzed for TCLP } \\
\text { VOCs. Based on TPH results } \\
\text { (Table A.3-2), Borehole } 1 \text { would have been more likely than } \\
\text { Borehole } 4 \text { to produce TCLP VOC results. Based on the high } \\
\text { concentrations of diesel and gasoline at depths of } 30 \text { feet or more, } \\
\text { additional sampling in the areas of highest contamination is } \\
\text { required. This sampling should be conducted at the Aboveground } \\
\text { Storage Tank (AST) area (Borehole B-14) as well as the Burn Pit } \\
\text { area (Borehole B-1). These samples should be analyzed for TCLP } \\
\text { VOCs at depths which represent the highest concentrations. }\end{array}$ & \multicolumn{2}{|c|}{$\begin{array}{l}\text { The text was changed to read: Three samples (FTP00089, } \\
\text { FTP00091, and FTP00107) were analyzed for TCLP VOCs } \\
\text { to support waste management decisions. Sample } \\
\text { FTP00107 was collected at a location (B-4, } 4 \text { - to 5-ft bgs) } \\
\text { identified in the CAIP (DOE/NV, 1998) as a likely place for } \\
\text { chlorinated hydrocarbon contamination. Samples } \\
\text { FTP00089 and FTP00091 were collected from B-1 at 0- to } \\
1 \text {-ft bgs and 4- to 5-ft bgs. No constituents were identified } \\
\text { above RCRA regulatory levels in any of these samples. No } \\
\text { VOCs were identified in this sample, or in other samples } \\
\text { from borehole B-4 or borehole B-1, above PALs. }\end{array}$} & Yes \\
\hline $\begin{array}{l}\text { 2) Section 4.0, } \\
\text { Recommended } \\
\text { Alternative }\end{array}$ & M & $\begin{array}{l}\text { Based on the high concentrations of diesel and gasoline remaining } \\
\text { in the soil at this site, along with the potential for other COCs, NDEP } \\
\text { does not concur with Alternative 2, Closure in Place with Partial } \\
\text { Excavation, Disposal, and Administrative Controls. Once additional } \\
\text { data are required, NDEP will evaluate proposed alternatives } \\
\text { including the need for active remediation activities. }\end{array}$ & \multicolumn{2}{|c|}{$\begin{array}{l}\text { Alternative } 4 \text { was added and selected as the recommended } \\
\text { Alternative. }\end{array}$} & Yes \\
\hline
\end{tabular}

a Comment Types: $\mathrm{M}=$ Mandatory, $\mathrm{S}=$ Suggested

Return Document Review Sheets to DOE/NV Environmental Restoration Division, Attn: QAC, M/S 505. 


\section{NEVADA ENVIRONMENTAL RESTORATION PROJECT}

DOCUMENT REVIEW SHEET

(Page 2 of 3 )

\begin{tabular}{|c|c|c|c|c|c|}
\hline \multicolumn{4}{|c|}{$\begin{array}{l}\text { 1. Document Title/Number: Draft Corrective Action Decision Document CAU 342: Area 23, Mercury Fire } \\
\text { Training Pit, Nevada Test Site, Nevada }\end{array}$} & \multicolumn{2}{|l|}{ 2. Document Date: December 1998} \\
\hline \multicolumn{4}{|c|}{ 3. Revision Number: Draft and Revision 0} & \multicolumn{2}{|c|}{ 4. Originator/Organization: IT Corporation } \\
\hline \multicolumn{4}{|c|}{ 5. Responsible DOE/NV ERP Subproject Mgr.: Janet Appenzeller-Wing } & \multicolumn{2}{|l|}{ 6. Date Comments Due: } \\
\hline \multicolumn{6}{|c|}{ 7. Review Criteria: Full } \\
\hline \multicolumn{4}{|c|}{ 8. Reviewer/Organization/Phone No.: Michael D. McKinnon, NDEP } & \multicolumn{2}{|l|}{ 9. Reviewer's Signature: } \\
\hline $\begin{array}{l}\text { 10. Comment } \\
\text { Number/ } \\
\text { Location }\end{array}$ & 11. Type* & 12. Comment & \multicolumn{2}{|c|}{ 13. Comment Response } & $\begin{array}{l}14 . \\
\text { Accept }\end{array}$ \\
\hline $\begin{array}{l}\text { 1) Page } 6 \text {, } \\
\text { Section } 2.1 \text {, } \\
2^{\text {nd }} \text { Paragraph, } \\
3^{\text {rd }} \text { Bullet }\end{array}$ & & $\begin{array}{l}\text { "... ranged in depth from } 15 \mathrm{ft} \text { to } 21 \mathrm{~m} 70 \mathrm{ft} . . . " \text { Change to "...ranged in } \\
\text { depth from } 15 \mathrm{ft} \text { to } 70 \mathrm{ft}(21 \mathrm{~m}) . . .\end{array}$ & \multicolumn{2}{|c|}{ Deleted "21 m" } & Yes \\
\hline $\begin{array}{l}\text { 2) Page } 16 \text {, } \\
\text { Section } 3.3 \text { and } \\
\text { Page A-43, } \\
\text { Section A.3.10.1 }\end{array}$ & & $\begin{array}{l}\text { These sections indicate that existing conditions are favorable for } \\
\text { natural biological degradation. Will natural biological degradation } \\
\text { effectively reduce long-chain hydrocarbons (such as diesel fuel)? If } \\
\text { not, biodegradation is not a feasible alternative at this site. }\end{array}$ & \multicolumn{2}{|c|}{$\begin{array}{l}\text { Yes. Aerobic biodegradability half-life for diesel fuel } \\
\text { components ranges from approximately one week to one } \\
\text { year for both vadose and saturated zones. }\end{array}$} & No \\
\hline $\begin{array}{l}\text { 3) Page } 16 \text {, } \\
\text { Section } 3.3 .2 \\
3^{\text {rd }} \text { Paragraph }\end{array}$ & & $\begin{array}{l}\text { In addition to administrative controls restricting personnel access to } \\
\text { this site, controls to prevent access to burrowing animals and desert } \\
\text { tortoises is appropriate (fencing). }\end{array}$ & \multicolumn{2}{|c|}{$\begin{array}{l}\text { Fencing will not prevent access by burrowing animals. The } \\
\text { backfill material will be compacted to ambient conditions or } \\
\text { greater to limit burrowing. }\end{array}$} & No \\
\hline $\begin{array}{l}\text { 4) Page A-8, } \\
\text { Table A.2-1 }\end{array}$ & & Sample location C-1 is not indicated on Figure A.2-2. & \multicolumn{2}{|c|}{$\begin{array}{l}\text { A Geoprobe® sample was not collected in Cell C-1. The } \\
\text { table will be revised to reflect that no analysis was done. }\end{array}$} & No \\
\hline
\end{tabular}




\section{NEVADA ENVIRONMENTAL RESTORATION PROJECT}

DOCUMENT REVIEW SHEET

(Page 3 of 3 )

\begin{tabular}{|c|c|c|c|c|}
\hline $\begin{array}{l}\text { 10. Comment } \\
\text { Number/ } \\
\text { Location }\end{array}$ & 11. Type* & 12. Comment & 13. Comment Response & $\begin{array}{l}14 . \\
\text { Accept }\end{array}$ \\
\hline $\begin{array}{l}\text { 5) Page A-20/2, } \\
\text { Table A.3-2 }\end{array}$ & & $\begin{array}{l}\text { From this table, it appears there is minimal contamination in the } 0-5 \\
\text { foot region, while contamination increases with depth down to } \\
\text { approximately 20-30 feet. By removing the top } 5 \text { feet of soil in the } \\
\text { areas of the Burn Pit and the Above-ground Storage Tanks, the } \\
\text { potential for personnel contacting more heavily contaminated soil } \\
\text { increases. The proposal to remove the top } 5 \text { feet of soil in these } \\
\text { areas should be revisited and further justified. }\end{array}$ & $\begin{array}{l}\text { The areas to be excavated had results exceeding the action } \\
\text { level. Removal of the contaminated material will lessen } \\
\text { future dispersion. The excavations will be backfilled with } \\
\text { clean borrow material to limit future contact. The health and } \\
\text { safety of the workers involved with the excavation will be } \\
\text { controlled during the investigation. }\end{array}$ & No \\
\hline
\end{tabular}

${ }^{a}$ Comment Types: $M=$ Mandatory, $\mathrm{S}=$ Suggested

Return Document Review Sheets to DOE/NV Environmental Restoration Division, Attn: QAC, M/S 505. 


\section{Distribution}

*Provide copy in distribution of Revision 0 and subsequent revisions, if applicable. Copies of only the NDEP-approved document will be distributed to the others.

\section{$\underline{\text { Copies }}$}

Paul J. Liebendorfer

2 (Controlled)*

State of Nevada

Bureau of Federal Facilities

Division of Environmental Protection

333 W. Nye Lane, Room 138

Carson City, NV 89706-0851

Michael McKinnon

1 (Controlled)*

State of Nevada

Bureau of Federal Facilities

Division of Environmental Protection

555 E. Washington, Suite 4300

Las Vegas, NV 89101

Sabrina Lawrence

Environmental Restoration Division

1 (Controlled)*

DOE/Nevada Operations Office

P.O. Box 98518, M/S 505

Las Vegas, NV 89193-8518

Janet Appenzeller-Wing

1 (Uncontrolled)*

Environmental Restoration Division

DOE/Nevada Operations Office

P.O. Box 98518, M/S 505

Las Vegas, NV 89193-8518

Clayton Barrow

Environmental Restoration Division

1 (Uncontrolled)*

DOE/Nevada Operations Office

P.O. Box 98518, M/S 505

Las Vegas, NV 89193-8518

Shannon Parsons

1 (Uncontrolled)*

Bechtel Nevada

P.O. Box 98521, M/S NTS306

Las Vegas, NV 89193-8521 
Steve Nacht

Bechtel Nevada

P.O. Box 98521, M/S NTS306

Las Vegas, NV 89193-8521

Rob Boehlecke

SAIC

P.O. Box 93838

Las Vegas, NV 89193

Mary Todd

SAIC

P.O. Box 93838

Las Vegas, NV 89193

Dustin Wilson

SAIC

P.O. Box 93838

Las Vegas, NV 89193

Jeff Johnson

IT Corporation

P.O. Box 93838

Las Vegas, NV 89193

IT Corporation Central Files

IT Corporation

P.O. Box 93838

Las Vegas, NV 89193

Technical Information Resource Center

DOE/Nevada Operations Office

P.O. Box 98518, M/S 505

Las Vegas, NV 89193-8518

U.S. Department of Energy

Office of Scientific and Technical Information

P.O. Box 62

Oak Ridge, TN 37831
1 (Uncontrolled)*

1 (Uncontrolled)*

1 (Uncontrolled)* $^{*}$

1 (Uncontrolled)*

1 (Uncontrolled)*

1 (Uncontrolled)*

1 (Uncontrolled)

1 (Uncontrolled, electronic copy) 
Manager Southern Nevada FFACO

Public Reading Room

P.O. Box 98521, M/S NLV040

Las Vegas, NV 89193-8521

Manager Northern Nevada FFACO

Public Reading Room

c/o Rosa Silver

IT Corporation

P.O. Box 93838

Las Vegas, NV 89193

FFACO Public Reading Room Coordinator

Rosa Silver

IT Corporation

P.O. Box 93838

Las Vegas, NV 89193

Earl Dixon

Community Advisory Board

UNLV, Harry Reid Center for Environmental Studies

4505 S. Maryland Pkwy

Las Vegas, NV 89154

Dick Telfer

Community Advisory Board

5357 Spencer

Las Vegas, NV 89119
1 (Controlled)

1 (Uncontrolled)

1 (Uncontrolled)

1 (Uncontrolled)

1 (Uncontrolled) 